Florida International University FIU Digital Commons

$11-7-2014$

\title{
La tentación del abismo en Armonía Somers: entre el expresionismo de vanguardia y el gótico postmoderno
}

Anamaria Lopez-Abadia Laya

FIU, anamaria.lopez.a@gmail.com

DOI: $10.25148 /$ etd.FI14110762

Follow this and additional works at: https://digitalcommons.fiu.edu/etd

Part of the Modern Languages Commons

\section{Recommended Citation}

Lopez-Abadia Laya, Anamaria, "La tentación del abismo en Armonía Somers: entre el expresionismo de vanguardia y el gótico postmoderno" (2014). FIU Electronic Theses and Dissertations. 1662.

https://digitalcommons.fiu.edu/etd/1662 


\title{
FLORIDA INTERNATIONAL UNIVERSITY
}

Miami, Florida

\section{LA TENTACIÓN DEL ABISMO EN ARMONÍA SOMERS:}

ENTRE EL EXPRESIONISMO DE VANGUARDIA Y EL GÓTICO POSTMODERNO

\author{
A dissertation submitted in partial fulfillment of \\ the requirements for the degree of \\ DOCTOR OF PHILOSOPHY \\ in \\ SPANISH \\ by \\ Anamaría López-Abadía Laya
}


To: Interim Dean Michael R. Heithaus

College of Arts and Sciences

This dissertation, written by Anamaria López-Abadía Laya, and entitled La tentación del abismo en Armonía Somers: entre el expresionismo de vanguardia y el gótico postmoderno, having been approved in respect to style and intellectual content, is referred to you for judgment.

We have read this dissertation and recommend that it be approved.

$\begin{array}{r}\hline \text { Maida Watson } \\ \hline \text { Maria A. Gomez } \\ \hline \text { Santrid Arraras } \\ \hline\end{array}$

Date of Defense: November 7, 2014

The dissertation of Anamaría López-Abadía Laya is approved.

$\begin{array}{r}\begin{array}{r}\text { Interim Dean Michael R. Heithaus } \\ \text { College of Arts and Sciences }\end{array} \\ \hline \begin{array}{c}\text { Dean Lakshmi N. Reddi } \\ \text { University Graduate School }\end{array}\end{array}$

Florida International University, 2014 


\section{ABSTRACT OF THE DISSERTATION \\ LA TENTACIÓN DEL ABISMO EN ARMONÍA SOMERS: \\ ENTRE EL EXPRESIONISMO DE VANGUARDIA Y EL GÓTICO POSTMODERNO}

by

Anamaría López-Abadía Laya

Florida International University, 2014

Miami, Florida

\section{Professor Santiago Juan-Navarro, Major Professor}

Armonía Somers (Uruguay 1917 - 1994) ha sido clasificada dentro de la llamada

Generación del 45 de Uruguay, sin embargo, muchos críticos aseguran que su obra difiere de la estética del período en que escribió. Mientras Ángel Rama sugiere que la narrativa de Somers pertenece a la tradición de los raros y malditos, que desciende del extraño linaje del Conde franco-uruguayo y poeta Lautréamont, otros la colocan en el ámbito de la narrativa imaginativa y de lo fantástico. La crítica contemporánea se aproxima a la obra de Somers a partir del concepto de lo extraño o "Unheimlich", abordando las novelas de la autora desde una perspectiva freudiana, lacaniana o heideggeriana. No obstante, ninguna de estas investigaciones ha determinado a qué género u orientación literaria se aviene, ni han indagado en profundidad sobre su contribución a los estudios metaficcionales.

En esta tesis propongo que las novelas de Armonía Somers, "La mujer desnuda" (1950), "De miedo en miedo. Los manuscritos del río" (1965), "Un retrato para Dickens" (1969), "Viaje al corazón del día. Elegía por un amor secreto” (1986), y "Solo los elefantes encuentran mandrágora" (1986), transgreden los géneros y tendencias 
literarias dominantes en su época por medio de una imaginación excesiva y de una trama anti-dramática, asociada primordialmente con la experiencia del terror sublime y la representación de lo inexpresable o irrepresentable, ambas nociones correspondientes a la poética expresionista de vanguardia y al gótico postmoderno. Las novelas analizadas en este trabajo presentan en su estructura una amplia gama de formas ambiguas e inorgánicas, cuya función desestabiliza los aspectos formales del realismo y subvierte los postulados epistemológicos e ideológicos en que se apoyan las culturas afirmativas, las cuales legitiman solo cierto concepto de realidad, desentendiéndose del resto de las experiencia humanas que no encajan en sus esquemas. La desacralización, la disolución moral, la muerte simbólica y la naturaleza fluida de la identidad junto con una marcada autorreflexividad, son algunos de los temas más relevantes de este conjunto de obras, que he categorizado como un ejemplo del expresionismo gótico postmoderno del siglo XX. 


\section{TABLA DE CONTENIDO}

\section{CAPÍTULO}

\section{PÁGINA}

Introducción 1

\section{Capítulo 1}

Aproximación a las corrientes estéticas en la narrativa de Somers .14

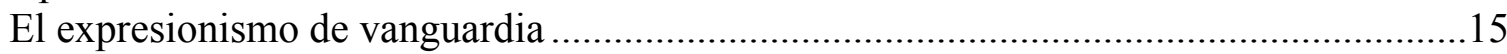

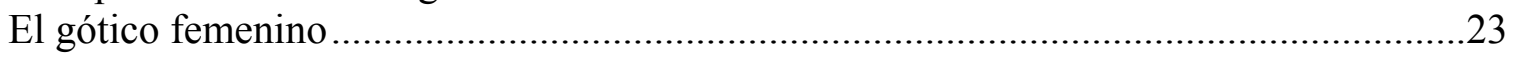

El gótico postmoderno

\section{Capítulo 2}

Del expresionismo al gótico postmoderno: "La mujer desnuda" (1950) ............................34

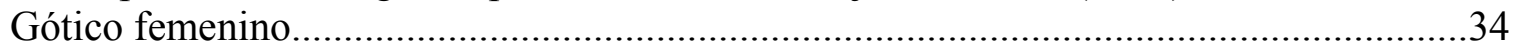

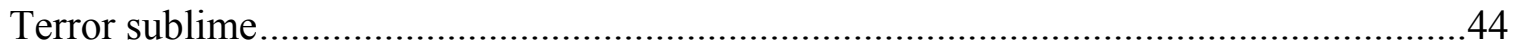

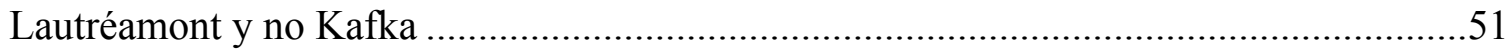

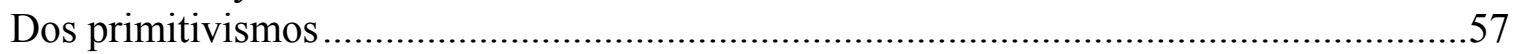

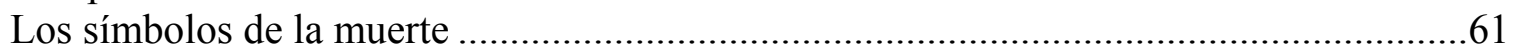

\section{Capítulo 3}

Subjetividad gótica postmoderna: "De miedo en miedo.

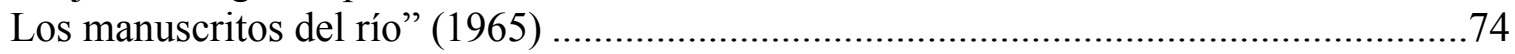

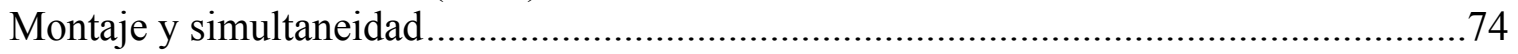

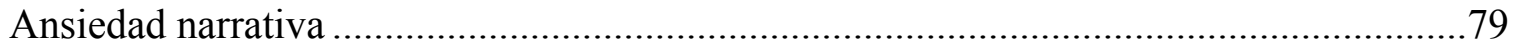

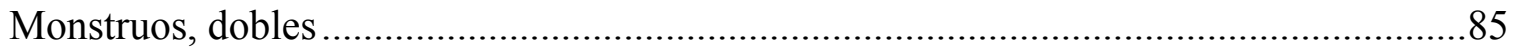

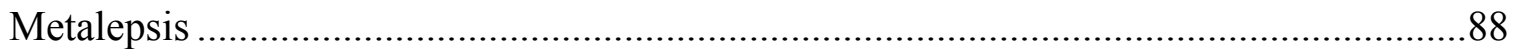

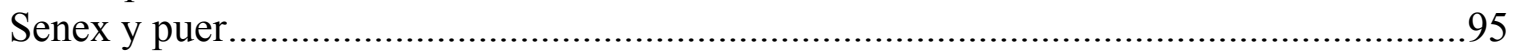

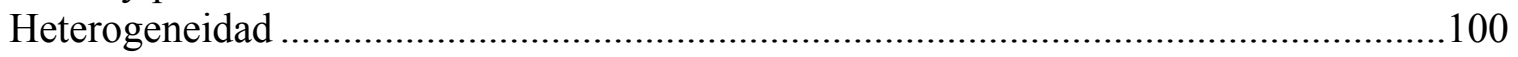

Capítulo 4

Terror prototípico y postmodernidad en "Un retrato para Dickens" (1969).....................106

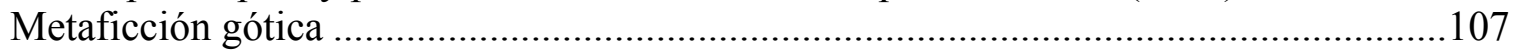

Los signos de la postmodernidad ...........................................................................112

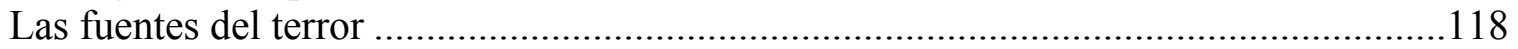

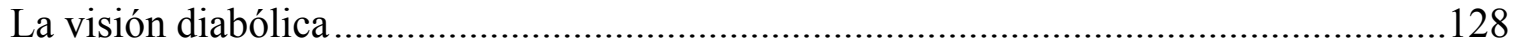

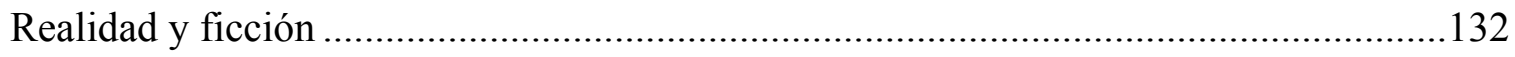

\section{Capítulo 5}

De la elegía gótica al "teleteatro": amor, muerte y postmodernidad en

"Viaje al corazón del día. Elegía por un amor secreto" (1986) ........................................139

Confluencia de los géneros literarios en Viaje ..........................................................139

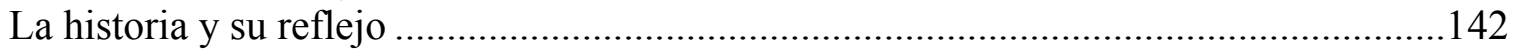

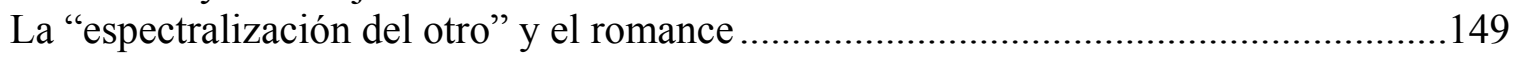

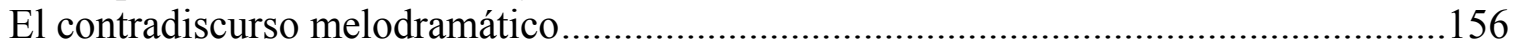


Novela y realidad

\section{Capítulo 6}

Una poética del exceso. "Solo los elefantes encuentran mandrágora" (1986)

La calavera....

La burla 176

Lo indecible y lo extraño 180

La transgresión, el exceso 184

La expiación 190

Conclusiones

Referencias. 218

Vita. .225 


\section{Introducción}

A más de medio siglo de los relatos que inauguraron la obra de Armonía Somers (Montevideo, 1933 - 1994), El derrumbamiento (1948) y La mujer desnuda (1950), la inquietud por definir la rara belleza de su prosa, la densidad de sus temas y complejidad de su literatura no ha cesado de inspirar numerosos ensayos dedicados al estudio de sus veinticinco cuentos, sus cinco novelas y sus “trípticos”. La crítica sobre la narrativa de Somers, que cuenta con casi una centena de artículos entre literarios y periodísticos, un par de libros y algunas tesis inéditas, ha prestado especial interés al carácter visceral, "fantasmagórico" e imaginativamente delirante de su escritura, catalogada de "difícil" desde el punto de vista de su estructura, de su sintaxis y significación. Otros han ahondado en el tratamiento casi luciferino de los tópicos del amor, el destino, la soledad, la muerte y la metamorfosis, en la visión retorcida de arquetipos y dislocación persistente de roles inveterados, y, finalmente, en la forma poética de concebir el mundo desde la fuente más íntima y abismal del ser humano.

En torno a estos temas el criterio es variado, pero la necesidad de hallar las bases de una articulación de fondo es unánime. Se trata de la misma preocupación que muestra Ángel Rama en la década del sesenta, cuando apunta que de todos los escritores de la “Generación de crisis” del 45, Somers es "quien más tesoneramente representa el espíritu experimental, inconformista, subjetivo (...) y en quien justamente es más difícil desentrañar las influencias literarias" (11). Esta problemática intrínseca a la narrativa

\footnotetext{
${ }^{1}$ Véase en el prólogo a la antología Aquí, cien años de raros (énfasis mío). Otros integrantes de la "Generación del 45", en la que a veces figura también Rama, incluyen a Mario Benedetti, Mario Arregui, Carlos Martínez Moreno, Amanda Berenguer, Idea Vilariño, Ida Vitale, María Inés Silva Vila y José Pedro Díaz, por mencionar sólo algunos.
} 
de Somers es el punto de partida de este estudio, su matriz organizadora, diríase: el desarrollar un marco de referencia común que permita distinguir las formas manifiestas a lo largo de toda su obra; un género o varios géneros aliados que establezcan las redes de sentido de su ficción en sus distintas fases y desplieguen, asimismo, la "unidad profunda" de la obra en su conjunto. ${ }^{2}$

Hasta ahora uno de los géneros más asociados con la narrativa de Somers ha sido la llamada "literatura imaginativa" propuesta por Rama, vinculada con el oscuro linaje del poeta franco-uruguayo, Conde de Lautréamont (1846-1870). Ésta ha sido, sin duda, una de las observaciones más lúcidas respecto a las motivaciones más tenaces en la literatura de la autora, principalmente en lo que concierne a su inclinación por la estética surrealista, y por el gusto al culto del "mal" y al horror que se desprende de sus historias. Sin dejar de admitir el realismo "profundo" por el que apuesta Rama, hay quienes no obstante señalan rasgos de una tendencia fantástica. Se ha estudiado la obra desde la perspectiva de una "literatura femenina" o de género, también, en el sentido de que evade deliberadamente modelos estéticos patriarcales con el fin de recrear un universo “intuitivo, emocional, sensorialista, a su manera mitificador” (Moraña 187). La mayoría de los estudiosos, sin embargo, coinciden en la presencia marcada de aspectos expresionistas, sobre todo en el lenguaje lírico y en el carácter subjetivo, "hiperestésico" de su escritura. Cualquiera sea el lenguaje que la crítica haya encontrado para extraer el sentido último de esta narrativa, lo cierto es que al hacer una lectura comparativa de sus

\footnotetext{
${ }^{2}$ Hablamos de formas que se "manifiestan" en la narrativa de Somers, porque creemos, junto con Todorov, que "una obra manifiesta tal o cual género, y no que éste existe en dicha obra. (...) esta relación de manifestación entre lo abstracto y concreto es tan sólo probable; en otras palabras, no hay ninguna necesidad de que una obra encarne fielmente un género: sólo existe la probabilidad de que ello suceda. Esto significa que ninguna observación de las obras puede, en rigor, confirmar ni invalidar una teoría de los géneros" (13).
} 
posturas puede repararse, no sin sorpresa, en que todos llaman con distintos nombres lo que en los textos de la autora se muestra como una narrativa expresionista hermanada con el género gótico postmoderno.

La incidencia temprana de un modernismo expresionista que a ratos se muestra en su forma más pura y, en oportunidades, se alía con el surrealismo, lo sugiere Rama en su artículo archicitado por los críticos y pionero en el descubrimiento de la singularidad de Somers: "Aquí, cien años de raros", en el que remite a una "literatura imaginativa" que

Desprendiéndose de las leyes de causalidad, trata de enriquecerse con ingredientes insólitos emparentados con formas oníricas, opera con provocativa libertad y, tal como sentenciara el padre del género, establece el encuentro fortuito entre la mesa de disección del paraguas y la máquina de coser. (9)

La relación que Rama plantea entre la configuración del relato y la del sueño es fundamental para la comprensión de la obra de Somers, porque subraya el sustrato expresionista-surrealista en que se asienta su estructura narrativa temprana. La mujer desnuda, por ejemplo, cobra mucho más sentido si se tiene en cuenta desde un principio la lógica onírica en que se producen los hechos, si se advierte que el interés radica en evocar una atmósfera, no un lugar definido. ${ }^{3}$ Esta concepción subjetiva del espaciotiempo, de estar frente a una "realidad alucinada" o "pesadillezca" la comparten muchos críticos, si bien la mayoría de ellos insertan este fenómeno dentro de la literatura “imaginaria” a la que apuesta Rama. ${ }^{4}$ En la misma línea de pensamiento, Elena Martínez habla de la elaboración de un" no-lugar" en el cuento El desvío, cuyo tiempo "se

\footnotetext{
3 "Tanto el expresionismo como el surrealismo están profundamente interesados en el sueño, pero de maneras distintas (...). Mientras el surrealismo busca reproducir los sueños y las alucinaciones como tales, el expresionismo intenta más bien copiar la forma y el patrón de los sueños, no su contenido" (Sokel 37-8). Todos los textos de son traducciones mías.

${ }^{4}$ Algunos seguidores de la orientación "imaginaria" combinada con elementos fantásticos en la literatura de Somers son: María Rosa Oliveira-Williams, Lilia Dapaz Strout, Ana María Rodríguez Villamil.
} 
caracteriza por su subjetividad" (114). Por su parte, Alejandro Varderi se refiere a un “tiempo sin tiempo, o más bien un tiempo múltiple en que se entremezclan el pasado, el presente y lo histórico con los recuerdos del personaje" como un rasgo que se repite en distintos grados a lo largo de la obra (229). Es decir, el entorno físico del protagonista deja de estar fijo en un espacio determinado y se convierte en una proyección de sí mismo, del estado interior del personaje (Sokel 38). La percepción del tiempo está a merced de un tempus interior, de allí que muchas veces adquiera un ritmo "fantástico", cuando no "alucinante", al punto que para los propios personajes resulta "imposible de medir" ${ }^{5}$ La naturaleza discutible del género en Somers se debe en parte a esto, a que las coordenadas de tiempo y espacio no se corresponden "con el carácter comprehensivo de la cosmovisión que nos entrega", refiere Nicasio Perera, a esta "ausencia total de proyecciones extradiegéticas y a la insularidad (...) del espacio". Y aún añade "Es, pues, su propia realidad inmediata [la del relato], la que inspira las coordenadas del espacio y del tiempo" (24-5).

Si la voz narrativa no sigue un curso lineal de los hechos ni de la anécdota y da la impresión de estar ante una sucesión de imágenes en apariencia irreverente, como se ha apuntado tantas veces, es pertinente notar de nuevo que allí, como en los sueños, "se reemplaza el análisis intelectual por la visión directa” (Sokel 39). Evelyn Picón Garfield así lo confirma al describir la prosa de Somers como una suerte de "significantes encadenados" cuyos "indicios sensoriales nos devuelven (...) a un retrato visual más completo" (26). En realidad esta forma de representación no es exclusiva del expresionismo —éste sólo lleva la tendencia al límite-. Ya en la construcción de las

${ }^{5}$ En el cuento El desvío la protagonista se dice "imposible medir el tiempo". 
escenas del drama isabelino y barroco, especialmente shakesperiano, el cambio de escenas aparece borroso por la "velocidad" en que acontecen (Sokel 39). "La metralla de este fraseo es, sin duda, una de las fuentes de la violencia de Somers", subraya Perera, porque del movimiento compulsivo de esas series secuenciales de imágenes se desprende, desde luego, una agresividad que impregna a la audiencia, tal y como lo percibimos hoy día en el cine. En todo caso, este carácter cinematográfico de la sintaxis de Somers se señala, en rigor, como una especie de "barroquismo de la composición", que se traduce en una cosmovisión caótica y una "sistemática disrupción del texto (...) una inmensa, a menudo confusa descolocación metonímica entre eventos disímiles, cuya única relación entre ellos es la de ser atributo, causa, efecto, contigüidad lingüística o contigüidad de la memoria" (Visca 14; Kantaris 90).

Al decir "atributo", Elia Geofrey Kantaris parece remitir al leitmotiv expresionista por excelencia que se persigue desde las composiciones wagnerianas, pasando por los dramas expresionistas de Strindberg, hasta la literatura de Kafka: expresar la esencia de una figura o emoción por medio de símbolos, pero no un símbolo que representa una idea universal, como es en el caso de Goethe, por ejemplo, sino uno que sirve como modo expresivo de la obra de arte (Sokel 34). La escritura de Somers corporeiza este principio en todas sus dimensiones, desde la construcción sintáctica, la recreación de sus personajes, hasta el tipo de impacto que aspira causar en el lector. Todo es un atributo estético en el sentido de que cada frase, cada imagen, cada figura se concibe como un símbolo amén de "expresar una situación invisible" (Sokel 38). Sus caracteres, de hecho, son como notas de una secuencia musical que va esbozando una cadena de múltiples resonancias, de ecos significantes que configuran facetas inciertas. Varderi sugiere que 
Somers al crear sus personajes "más que individualidades, diseña colectivos de carne definidos por ese lenguaje" (229). Éstos cobran sentido, entonces, no a partir de la representación objetiva de un mundo externo, sino de un mundo cerrado en sí mismo, "autocomprimido", como el de una composición (Sokel 35). La autora, tan consciente del proceso creativo de su escritura, nos asoma esta intención en la importancia que otorga a la armonía en sus historias:

Para mí organizar la narración y echarla a andar acabada es como llevar la armonía al caos con que comienza el Génesis. No sé si un plástico sentirá lo mismo, pero puedo imaginarlo en la música, porque esa armonía le pertenece por antonomasia. (Campodónico 233)

La articulación de un relato consiste en recrear un universo en el que cada elemento tiene vida propia y, al mismo tiempo, no existe sino en relación con los otros. Como ella misma aduce, el "concierto universal de lo narrado (...) es un todo indiviso, aunque parezca lo contrario" (Campodónico 232). Por tanto, no sólo un personaje funciona como atributo, sino que todos ellos-y esto es crucial en la narrativa expresionista— son así; todos los caracteres constituyen modos expresivos, símbolos que personifican claves, posibilidades de la esencia del otro (Sokel 36). En Viaje al corazón del día, Mabel Moraña observa que la novela "se vuelca a la indagación de otros personajes cuyas propias historias individuales se nutren más o menos lateralmente de Laura. Es una red biográfica la que va saliendo a la luz" (190). El ser "atributo" no quiere decir que los personajes sean "abstracciones sin vida, por el contrario, éstos actúan normalmente de forma única y abierta, demuestran una individualidad marcada en su trato y en sus bizarras idiosincrasias" (Sokel 36). Tal vez esta sea la razón por la que ellos aparecen siempre como un misterio ante nosotros, porque "no representan ni una idea 
universal ni tampoco una individualidad concreta", porque encarnan una realidad y al mismo tiempo "aparecen como fragmentos de una misma mente" (Sokel 31, 40). De ahí que para algunos la rareza de estos seres que pueblan el mundo de Somers sólo puede entenderse dentro del imaginario fantástico. Ello se debe, también, a la condición "primitiva" e increíble que muchos poseen: una mujer que se corta la cabeza y sale desnuda al campo, estatuas que hablan, ángeles planeadores, Asmodeo y otros demonios, por nombrar unos pocos (Perera 30).

Efectivamente, ciertos detalles insólitos, “distorsiones o exageraciones poco plausibles, un giro grotesco, una incongruencia intencional, apariciones empíricamente imposibles en tiempo y espacio destruyen nuestra ilusión de estar frente a personajes de tres dimensiones, de carne y hueso" (Sokel 38). Mas ese modo de conducirse, a primera vista atípico, tiene que ver nuevamente con el estado onírico, con el hecho de estar en presencia de seres "que aparecen vívidamente en sueños", que no sólo exponen sus pensamientos al instante, sino que actúan de forma inmediata sobre ellos (37). Rebeca Linke, protagonista de La mujer desnuda (1950), recuerda "que dentro de su libro de cabecera había una pequeña daga" y tras breves razonamientos "El filo penetró sin esfuerzo, a pesar del brazo muerto, de la mano sin dedos" (Somers 18). Allí como en el drama expresionista "el deseo se torna acto, la emoción, evento" y aún, siguiendo a W. Sokel, podríamos añadir, que el mundo narrativo de Somers "no es una fuente de experiencia sino una estructura diseñada con el fin de expresar emociones", en vista de que "se sirve de la imaginería expresionista para acercarse a los sentimientos difíciles de expresar en un momento crítico" de odio, pasión, desilusión, desequilibrio mental, soledad (Sokel 38-9; Picón Garfield 29). 
Es justamente la emoción, el "uso riquísimo de afectividad" y sobre todo, la sensibilidad llevada al límite de su enunciación, donde los géneros expresionista y gótico parecen pactar en el corazón de la prosa de Somers, pues ambas formas se avienen en la intención de transmitir, en una especie de asalto, el clima inefable de "las fuerzas que irradian del alma" (Sokel 37). El leitmotiv del gótico es, precisamente, sacudir al lector en su interior con "fuertes emociones", conmover, impactar, golpear la sensibilidad del lector (Botting, Gothic 168). En palabras de Mary Shelley: "to curdle the blood and quicken the beatings of the heart" (Leewen 34). Mas lo que estrecha la consanguinidad de estos géneros es específicamente el tipo de emoción que producen, el clima peculiar que evocan y el significado de esa experiencia en términos de la relación del individuo y el mundo.

Los textos de Somers, se ha dicho, causan "una reacción más visceral que cerebral, una sensación de no poder acertar el fundamento exacto de la perturbación. Son textos que imprimen un estado de pérdida, (...) que incomodan, que inquietan, que llevan al lector a una crisis con el lenguaje" (Picón Garfield 25). El goce estético aquí está marcado por la incertidumbre y la amenaza de la disolución, de la pérdida del sentido. Esta ambigüedad, que ya había tomado cuerpo en distintas esferas de la narración (personajes polifacéticos, atemporalidad, no-lugar, a-referencialidad y trastrueque sintácticos), ahora pisa el terreno de las creencias de un modo más directo, y lo hace instalando una incomodidad que se siente como "pérdida". Tras la lectura hazañosa del texto, en esa perpetua caza por el sentido, lo que queda es la sensación de ansiedad, distintiva de toda narración postmoderna (Botting, Gothic 170). La misma emoción característica de las narraciones góticas, el estar en estado de perenne angustia (haunted) 
(Lutz 86). Moraña dice que los personajes de Somers "se mueven al borde de un abismo que a través del miedo, la expectativa, la crueldad, la fascinación erótica, acecha también al lector" (188). Se entiende mejor entonces el porqué de la violencia contenida en el lenguaje de las narraciones, de ese "demonismo interior" que priva en los personajes, rasgos primordiales de la escritura de Somers, pues esa condición de estar al acecho, que es producto de una carencia, de algo que está ausente, que se ha "perdido", actúa como "la fisura de una herida que impulsa también su rebelión" (Ruffinelli 271).

Cuáles sean los motivos de esa fisura o herida profunda es algo que Ángel Rama sintetiza en "un afán desesperado de ascetismo", en un universo caótico del que "se ha alejado, se ha amputado, la presencia de Dios" (30). De acuerdo con esto, Somers retoma y reelabora en el contexto de la postmodernidad la representación arquetípica de la “escisión”, es decir, la muerte de Cristo como un hombre mortal, cuya representación más significativa se encuentra en el Cristo muerto de Hans Holbein el Joven (1497-1543) (Kristeva 116). En esta pintura Jesús yace solo, nadie lo ve, nadie lo acompaña, acaso el pintor y "nosotros" (117). La situación no es distinta en las historias de Somers. Como el cadáver representado, personajes y lectores permanecen "en la cuerda floja", "Para hundirse en la muerte (...) límite inherente de la vida" (117). "La literatura de Armonía Somers ronda el horror de la descomposición y la muerte (...) Quizás no haya obsesión más dominante aquí que la del memento mori tradicional de cristianismo" (Rama, La fascinación 30). Y esa es la fuente del terror de esta literatura, que nos obliga a reflexionar sobre la condición de estar abandonados en un mundo en el que "lo demoníaco responde a un poder superior”, y donde nos obliga no sólo a ver la muerte sin trascendencia, sino que la "refriega contra nosotros para tratar de contaminarnos - que 
nadie quede ausente de este horror real- y conducirnos de este modo al desasosiego de un mundo inseguro rompiendo nuestros trillos habituales" (30).

En esta línea de pensamiento, cabe entroncar así en la narrativa somersiana el motivo del desmantelamiento sistemático de lo que comúnmente se ha tenido por imágenes venerables. Ello es lo propio del gótico postmoderno: que esa "energía rebelde" amenace y desacralice imágenes que han perdido su razón de ser, como la virgen vengativa del cuento El derrumbamiento (Botting, Gothic 172). El peligro que se corre en este territorio despojado de Dios, que corresponde tanto al inframundo expresionista como al terror gótico, es la apertura de ese campo abierto, que precisamente por carecer de límites lo permite todo. Y esto es algo que la autora explora con "oscura delectación”, lo que se ha visto como un hábito de su escritura al "mal". A lo largo de toda su narrativa, el mal está vinculado con la imaginación, sobre todo con aquella que se asocia a lo invisible, lo inanimado, a donde "nada permanece encubierto" (Varderi 233). Ese es el campo en que lo ausente, que se sabe como tal, por vía de esta imaginación cede a un "lleno", aunque se trate al fin de una "imagen de la plenitud frustrada, acaso ilusoria, acaso imposible" (Ruffinelli 273). Hay quienes llaman este proceso "la concretización de lo intangible", algo que se observa en la retórica de Somers, pero que se opera primero en la imaginación de sus criaturas, en sus "visiones" de la realidad que viven, y que responde, más bien, a esas "situaciones jeroglíficas que nos colocan en el camino secreto" que señala Artaud (Picón Garfield 25). Y el camino secreto no es sino el que conduce al "umbral" de la propia individualidad, al descubrimiento de "lo otro que hay en nosotros mismos, o al mismo que hay en el otro", en donde anidan terrores atávicos, 
oquedades, anhelos insondables, prejuicios anquilosados, deseos inexpresables (Perera 32).

En la literatura de Somers el paso de ese umbral no está garantizado. Como en la mitología ovidiana sus metamorfosis también tienen categorías y en algunos casos, quizás menos heroicos, esa transformación no se da. La humanidad es cualidad que se conquista, y ya sabemos a qué costo. La lucha por esa conquista como ritual y mística rediviva de sí es parte del reto a que invitan sus relatos.

La manifestación de este género híbrido en el marco de la literatura de Somers adquiere distintos matices e intensidad en las distintas novelas, lo cual es el segundo objetivo de esta investigación: puntualizar los elementos estructurales, de contenido y sentido en cuyos estadios, franjas de significación y alcance, se perfilen con línea visible en el espectro narrativo de la autora. A grandes rasgos, la crítica ha distinguido dos ciclos en la ficción de Somers, uno que corresponde a un período temprano y otro a un período de madurez. El cambio se atribuye más que todo a la estructura, al uso de recursos y al tratamiento de los temas. El primer bloque o estadio contempla la ficción que aparece del año 1950 al año 1965. Por orden de publicación incluye: La mujer desnuda (1950), El derrumbamiento (1953), Todos los cuentos (1953-1967) —dieciocho en total—, y la novela De miedo en Miedo (1965). Jorge Ruffinelli caracteriza esta primera parte creativa de enorme rebeldía:

Todo el satanismo —esa metódica arremetida contra los símbolos sagrados de la religión o de la sociedad, como violenta y justa iconoclastia-, toda la crueldad volcada ahora sobre el mundo, encarnan como expresión de una requisitoria que en su ahondamiento acabará por comprender el mal en un nivel más profundo, pero que aún no revela los valores ciertos y definidos de su rebelión, si es que no se infieren de su ausencia. (271 énfasis mío) 
En este ánimo disidente todavía embrionario de los primeros escritos, el narrador adopta una distancia irónica hacia los personajes y en general se perfila, según J.M. García Rey, toda una "filosofía pesimista" en la que prevalece el desprecio por la vileza humana, la rabia ante "un imprevisible destino (...) que la voluntad no puede regir y que ha terminado por hacer de ésta, una extraña tierra del desencuentro" (Ruffinelli 273). Este existencialismo exacerbado "sin concesiones" hace que los relatos de este ciclo den una impresión "fuertemente desagradable al primer contacto" (Rama, La fascinación 30).

El segundo bloque narrativo o período de madurez comienza con la novela $U n$ retrato para Dickens (1969) y abarca el resto de la producción narrativa de Somers: Tríptico darwiniano (1982), Viaje al corazón del día (1986), Sólo los elefantes encuentran mandrágora (1986) y El hacedor de girasoles (1994), su "tríptico" póstumo. En general los argumentos ganan en realismo porque las historias tienen una ubicación espacio-temporal más reconocible. La intertextualidad se ve enriquecida por nuevas estrategias narrativas, líneas experimentales que ya había explorado en su primera fase, pero que ahora se enlazan con "un contar sabroso, (...) una anécdota elegante, (...) de una perfección de estilo (...) que inaugura un equilibrio más profundo entre la historia que narra y el dominio de su voz" (Ruffinelli 274). La convergencia de lo real y lo imaginario, la vena metafísica y ascética que trasuntan los relatos y su intento de narrar lo inenarrable se acentúa. La "profundización del mal" que se efectúa en esta época hace que el espectro gótico postmoderno resalte con más fuerza y sea la nota dominante de esta última fase. 
En diálogo con los hallazgos precedentes, este estudio persigue dar una articulación más sólida en torno a la estética a la que se aviene la narrativa de Somers. El análisis individual de las novelas permitirá así delinear estas relaciones y establecer analogías entre las obras, a medida que se avance en la indagación de éstas y se detalle su paulatina transformación. Por medio de la revisión de los puntos de encuentro y engranaje de la crítica, así como la demarcación de sus contrastes y validez de cara a los textos, el propósito es mostrar lo más claramente posible cómo aparecen los signos de un expresionismo gótico postmoderno en el entramado interior de los relatos. La distribución de los capítulos marcarán las pautas de cambio y continuidad, de evolución del género si se quiere. La reinterpretación de los textos narrativos de Somers en el marco de este género híbrido pretende analizar por primera vez todo el corpus novelesco de Somers, las cinco novelas en su conjunto, profundizando en la relación que existe entre ellas, en su fuente de origen común. 


\section{Capítulo 1. Aproximación a las corrientes estéticas en la narrativa de Somers}

La narrativa de Somers ha sido objeto de controversia en torno a la orientación estética de sus escritos. La "calidad original profunda" de sus obras la ha situado en una especie de limbo literario, de la prosa "más absurda, aunque sea la más torturada, la más difícil” (Rama Mujeres, 50). María Cristina Dalmagro, siguiendo los pasos de Ángel Rama, acuerda su ubicación en el marco de la "generación de la crisis" del Uruguay, cuya nota común sería la visión latinoamericanista y la crítica al proceso, típica de los años sesenta (56). Pero ya desde su primera novela, La mujer desnuda (1950) Somers se había adelantado en la exploración de la analogía entre cuerpo y literatura, tópico postestructuralista, y ni siquiera entonces pudo ser estrictamente estudiada desde la crítica feminista (Pérez de Medina 28). El volumen de ensayos dedicados solo a la investigación de la narrativa de Somers, publicado por Rómulo Cosse en 1990, corrobora el estatus ambiguo de la obra general de la autora, donde con frecuencia se alude a la difícil categorización e imposibilidad de registrar sus historias en un género particular. La literatura fantástica y el énfasis en lo imaginativo resultan aquí un género demasiado holgado si se considera que el ser de la literatura es de por sí fantástico. Más pertinente resultan las observaciones, frecuentes también, del gusto por el exceso, el desorden, el vacío, la implacable observación de la realidad y el "derrumbamiento" sistemático de toda convención que caracterizan las novelas de Somers. Un repaso de los aspectos más relevantes del expresionismo de vanguardia, del gótico femenino y gótico postmoderno puede arrojar una luz sobre los mecanismos que sirven de base a la estética huidiza de 
Somers, y posibilitar, así, una orientación y aproximación enriquecedora a su literatura. El expresionismo de vanguardia

En la revisión que hace Richard Murphy sobre el expresionismo en relación con la vanguardia, el modernismo y la postmodernidad, se entra en detalle sobre el cambio epistemológico y paradigmático que lleva a cabo este multifacético movimiento estético de cara a los intentos de deconstrucción, relectura de imágenes y percepción de la realidad, y cómo se distingue del resto de los modernismos (el cubismo, el dadaísmo, el surrealismo, el futurismo) como contradiscurso propio de la vanguardia histórica (Murphy 49). Su estudio es de especial relevancia en lo que concierne a la prosa del expresionismo de vanguardia, ya que la mayoría de los estudios previos se concentran en el drama expresionista. Debido al estudio atento del expresionismo en la literatura en prosa y a sus conexiones con la postmodernidad, el texto de Murphy será la base de aproximación teórica a la estética expresionista de vanguardia en relación con la prosa de Somers, junto con eventuales comentarios de otros estudiosos en torno al movimiento. Caracterizada como una narrativa "intensamente personal" y "visionaria" que oscila entre la lógica y las leyes de lo real, la ficción expresionista busca primeramente desmantelar la realidad como constructo ideológico de los discursos sociales dominantes (Murphy 98). Por discurso dominante entendemos toda práctica y formas de representación ideológicas que dictan una percepción de la realidad y se instauran como convenciones, ya sea por la vía política, social o cultural, en aras de modelar el imaginario del colectivo. La noción de ideología o de discurso ideológico en términos de hegemonía es uno de los principales conceptos a los que se opone la literatura expresionista de vanguardia, hegemonía tal y como la concibe Raymond Williams, como 
"un sistema de valores constitutivos y constituyentes", cuya práctica se consiente recíprocamente, tanto del lado de quienes ejercen el poder como del colectivo (108).

De acuerdo con Peter Bürger una de las convenciones artísticas asociadas a esta cultura "afirmativa" o hegemónica del arte es la creación de "falsas reconciliaciones" en la subjetividad del individuo por medio de la ilusión estética de un mundo armonioso o de un todo comprensible (48-9). A estas imágenes compensadoras son precisamente a las que el expresionismo se opone mediante un "contradiscurso", esto es, la reproducción de experiencias de profunda alienación por vía de una trama antidramática, en la cual el conflicto no se desarrolla sino que está presente de principio a fin, sin alcanzar una resolución o un sentido último (Murphy 19). Así, mientras que el desarrollo convencional de una trama realista se presenta de manera ordenada, cerrada y estática, y tiende a paralizar o a suspender toda reflexión sobre posibles alternativas, el texto vanguardista se comporta de manera subversiva, interrogando esas fijaciones y afirmando de esta manera que "la realidad no existe como totalidad" (260). La realidad desde este punto de vista es una construcción que de ser perceptible lo es solo de forma fragmentaria, irregular y contradictoria, sin asumir nunca un carácter de "totalidad" sino más bien el de una “interrupción” (260).

De allí que la prosa expresionista se caracterice por ser "inorgánica": el paso de un tramo a otro de la historia sin conexión a un conflicto central deshace la idea de unidad y el sentido artificial de un mundo armónico. Lo mismo ocurre con el tratamiento de los personajes, que a ratos "adoptan la forma de una persona real, otras la de un tipo abstracto, a veces dialogan sin ilación o irrumpen de súbito con monólogos líricos” (Pinthus 680). En lugar de presentar una perspectiva integral de la realidad, el tiempo y el 
espacio pierden asimismo su causalidad volviéndose un capricho o mero reflejo de la subjetividad del protagonista (Sokel 39). Este tipo de estructura obedece a la forma del montaje de la "épica", similar a la que empleaba Brecht en su teatro anti-ilusionista épico y a la forma fragmentada de los "Ich-Drama” expresionistas (“dramas del sí mismo"). En estas piezas la trama lineal convencional se desplaza a favor de una serie de eventos en que una figura protagónica discurre de una meditación a otra sobre sí misma sin rumbo definido (Murphy 140, 80). Llevado esto al plano del texto tal estructura se percibe como una discontinuidad, cuyo fin es provocar el cuestionamiento en el espectador o lector y alterar su relación con el arte, donde el significado de la obra no esté "pre-fabricado" ni dé la sensación de tener un sentido unívoco (79). Por medio de esta decepción el lector está así obligado a tomar una parte más activa en la reconstrucción de las partes y, lo que es más significativo, a encontrar por sí mismo el sentido de la obra.

La poética expresionista busca extraer la esencia de la situación sin tomar en cuenta los detalles realistas superfluos del asunto, puesto que no le interesa presentar "verdades" exteriormente reconocibles o formas completas. En lugar de ello se esmera en presentar una “visión" que es simultáneamente una expresión de la subjetividad. ${ }^{6}$ De esta manera enfatiza su arbitrariedad y su carácter inconcluso, y afianza su naturaleza como una creación mítica, dejando abierta la posibilidad de construcciones alternativas de lo real. En este sentido, la función del contra-discurso expresionista puede definirse como un texto que se niega a ser codificado en términos realistas y que intenta interrogar, al mismo tiempo, las formas racionalistas imperantes (principalmente de corte positivista-

\footnotetext{
${ }^{6}$ En su prefacio a The Dream Play (1902), August Strindberg explica que esta "visión" se interesa en reproducir la forma y el patrón de los sueños, no su contenido concreto. Según él, se trata de recrear un universo en el cual las leyes de la causalidad y las relaciones estén suspendidas con un solo propósito: el deseo de expresar una situación invisible (Sokel 38).
} 
científico, que son las que privan en todo texto realista clásico). De allí que los temas que lindan con lo racional y lo real, tales como la alienación, la locura, el inconsciente, lo intensamente ilógico y el caos sean prominentes en la literatura expresionista.

No en vano el aspecto "histérico" del expresionismo se acerca al modo literario del melodrama, cuyas formas excesivas de representación coinciden con la desestabilización expresionista de las convenciones, los códigos y sistemas de representación dominantes (Murphy 143). Efectivamente, el melodrama, al igual que el género gótico y fantástico, funciona como una forma de contradiscurso del realismo en términos de la construcción inorgánica de las figuras y de la trama, la cual se aviene a la forma de épica y montaje de la vanguardia. Primero, traza una línea argumental horizontal que se ve interrumpida por una serie de subtramas verticales, rompiendo así el hilo del suspenso y la ilusión de un todo armónico. Esta disposición conduce al lector a concentrarse no tanto en las tensiones de la trama, sino en el significado de tal disposición y cruce de historias, y en la complejidad de los múltiples planos de sentido (175). En segundo término, el melodrama acentúa la calidad de la imagen como símbolo pero desprendida de toda conexión alegórica tradicional, lo cual obliga al lector a descubrir el sentido propio de tales imágenes en el contexto individual en que se plantean.

La exageración propia de las caracterizaciones melodramáticas se corresponde también con la representación expresionista, en tanto que los personajes se muestran como meros tipos ("la mujer", "el padre") apuntando a su naturaleza iconográfica o conceptual que, de entrada, evade la ilusión de individualidad psicológica, y que sirven no obstante de vehículo para apuntar a una idea o a un conflicto (176). La idea es la 
expresión de un significado en exceso, que desborda el marco referencial común que tenemos del asunto. De esta forma el lector se ve compelido a contemplar las figuras y la situación desde una perspectiva más metafísica, psicológica o epistemológica que opera por debajo de la anécdota.

Ciertamente, la percepción del melodrama revela que el mundo "fáctico" de afuera es un mundo de apariencias, por lo que es completamente válido reemplazar ese mundo por una realidad "construida" o "conceptual", si se quiere, mediante la "visión" a que apela el expresionismo. Esta aproximación "visionaria" de la realidad comparte el mismo contradiscurso con el expresionismo en la medida en que "la imaginación melodramática hace el mundo moralmente más legible y pone al descubierto un universo oculto normalmente obscurecido por los sistemas de representación dominantes" (Murphy 178). Por esa razón ambos, el expresionismo y el melodrama, no toman en cuenta la descripción en detalle de la realidad; en cambio, exageran partes de ella en aras de evocar la moral esencial que trasuntan, pues "todo está conectado con la eternidad. La persona enferma no es una miserable criatura que está sufriendo. Ella es la enfermedad misma" (178).

Al mismo tiempo, el énfasis en la ausencia de clausura o interpretación última de la obra asocia el melodrama con las formas inorgánicas del expresionismo, ya que evade el quietismo propio de los efectos estéticos de las culturas afirmativas y la sublimación de la realidad en relación con los ideales artísticos, típica del Romanticismo o de los idealistas de la vanguardia. Las estrategias del contradiscurso del melodrama expresionista —el final abierto, la autorreflexividad y formas estilizadas, las voces de naturaleza desengañada, sin esperanza, el estatus conceptual de sus personajes y el 
carácter construido de la realidad - evaden de esta manera la tendencia a sublimar o a posponer los imperativos más urgentes de la realidad, conteniéndolos en el ámbito del ideal abstracto o resolviéndolos por vía de la esfera estética, en los aspectos formales armónicamente dispuestos del texto.

Simultáneamente, la calidad de constructo de sus representaciones admite que, dada la anomia de la modernidad, es preferible crear entonces sobre la base del vacío y "postular significados y sistemas simbólicos que no tienen mayor justificación, porque de igual modo no se sustentan en una teología ni en ningún código social universalmente aceptado" (Brooks 21). Desde las manifestaciones expresionistas más primitivas hasta las más ambiciosas —aquellas que pueden parecer a primera vista mundanas, sentimentales o simplemente desbordadas de pathos-, son todas formas contradiscursivas y funcionan de manera análoga al melodrama. De allí que su poética de la histeria (la imagen del grito que la define), "es capaz de crear la visión de la alteridad y un lenguaje del exceso con el cual puede comenzar a hablar sobre lo inexpresable" (Murphy 179).

Para resumir, lo que distingue al expresionismo de vanguardia del resto de las representaciones modernistas es su intención de deconstruir toda ideología de "arte" al tiempo que reflexionar sobre esas demarcaciones culturales que el modernismo ignora (258). Por lo tanto, un principio esencial del expresionismo de vanguardia es repensar el modo discursivo sobre una base "cínica" o de des-sublimación, que permite revertir las polaridades, esto es, desentronizar los ideales artísticos del romanticismo y colocarlos en un contexto mundano y material (259). Un método común de desestabilización del discurso normativo de la experiencia es alterar el sentido de "transparencia" y de 
“objetividad” del texto, que es lo propio de todo sistema clásico de representación. En este sentido, el expresionismo de vanguardia coincide con el punto de vista postmoderno cuando, al igual que este, desafía las nociones tradicionales de la perspectiva "externa" así como la de originalidad fundamentalmente a través del uso del pastiche y de la parodia.

La "reescritura" del mundo que emprende el expresionismo de vanguardia tiene que ver con la conciencia del carácter eminentemente discursivo de toda historia y realidad, lo cual se aviene con el concepto de "interconexión" que propone Linda Hutcheon en relación con la parodia, en tanto forma que permite reconocer la falacia que oculta toda historia, y de ver el pasado como realidad discursiva antes que como un hecho objetivo (24). La parodia constituye así un contra-discurso postmoderno y expresionista, porque acusa una autorreflexividad en el texto que subraya la arbitrariedad sobre la cual se construye el mundo, al tiempo que reconoce la provisionalidad de este juicio (Murphy 263). Quiere decir que tanto la parodia expresionista como la postmoderna no solo revelan la ficcionalidad inherente a toda cosmogonía, metalenguaje y metanarrativa, sino que acentúan, asimismo, el carácter pasajero de su propia afirmación o verdad.

Siguiendo el postulado de Hutcheon, en vista de que el conocimiento no puede escapar a la complicidad que mantiene con alguna metanarrativa, puede decirse que ninguna narrativa es "dominante" o porta la verdad, puesto que no hay tales jerarquías "naturales": todas son una construcción, una figuración humana (13). En este orden de ideas, el expresionismo de vanguardia así como la postmodernidad tienen un mismo fin, que es mostrar el carácter voluble de tales representaciones "totalizadoras" por medio de 
su relativización o desublimación de los principios que regulan la experiencia como un hecho unívoco.

Según Murphy esta percepción "nihilista" de la parodia conecta con el precepto nietzscheano de ruptura con la unidad cartesiana del ser, que le permite orientarse en el mundo y reconocerse en él (Murphy 265). Lo real sería entonces una constelación de signos y simulacros, donde la existencia de lo "original" está puesta en duda, objetivo inherente a la parodia. La creación de dobles, copias, ecos de un mismo ser colocados en el mismo estatus de relevancia del "original”, se corresponde con la construcción paródica del personaje postmoderno y expresionista de vanguardia, que persigue subvertir el sentido clásico de "control" del texto realista exponiendo el desdibujamiento de los límites entre la verdad y la ficción (269). Esto afecta la percepción de identidades, de las figuras y de situaciones, al punto de que la noción de una perspectiva "externa" estable y de una construcción retórica, textual e ideológica del texto se descalifica de continuo a favor de representaciones grotescas, fantásticas, melodramáticas o paródicas (272).

Siguiendo esta línea argumental, lo grotesco resulta asimismo una vía estratégica importante de desublimación expresionista. Al igual que en el expresionismo, el grotesco responde al desorden no ennobleciendo la experiencia, sino colocándola en el marco más irracional, al borde del delirio. La dinámica del texto grotesco descansa normalmente en una contradicción central: de un lado la representación de la realidad se basa en principios racionales acordes con los preceptos realistas, de forma que ambos, lector y personaje, logran orientarse y encontrar un sentido en el texto. No obstante, simultáneamente, esta misma estructura se desacredita a lo largo del relato, pasando de lo 
familiar a lo extraño, de la convención a la suspensión de tales valores, derivando en un territorio de alienación inexplicable (211). El motivo del sueño, del ser re-creado o del vivo como "muerto andante" es propio del grotesco, el cual se aviene a la idea de la inexistencia del gótico posmoderno y al tópico de la existencia sin identidad del expresionismo de vanguardia.

Vistas en conjunto, las manifestaciones de duplicidad y de ambigüedad de expresionismo de vanguardia tienen puntos de contacto relevantes con la postmodernidad e incluso con el gótico postmoderno en términos del uso de la repetición, de la figura del doble, de las estrategias desestabilizadoras del discurso realista y desublimación de toda metanarrativa, del sentido de inestabilidad general de todo "original". La aproximación "cínica" al arte y la vida, que revierte los pares opuestos realidad/ficción, sueño/vigilia, vida/muerte, etc. tiene como fin, al igual que la estética postmoderna, el cuestionamiento de la artificialidad de esas imágenes "estables" de la experiencia y de la racionalidad, y exponer las limitaciones de tal perspectiva unificadora, acentuando el carácter indecible o inexpresable de toda representación de lo real, que el sistema clásico de representación tiende a evadir o negar (259).

El gótico femenino

Fue Ellen Moers quien en 1976 acuñó el término de female gothic o gótico femenino para definir la prosa literaria de las escritoras que desde el siglo XVIII venían expresándose en el modo gótico (Moers 90). ${ }^{7}$ Ya sea porque algunas escritoras hayan

\footnotetext{
${ }^{7}$ Moers desarrolla su teoría del género en su libro titulado Literary Women a partir de un estudio sobre Frankenstein, en que interpreta la novela de Shelley como un drama femenino o como "el drama del posparto" (Fleenor 7). Más allá de los detalles de su análisis, el término de gótico femenino se asoció desde entonces con el carácter minoritario y de minusvalía de las escritoras femeninas, quienes, por su condición
} 
escogido el gótico conscientemente para distinguirse del discurso dominante o no, el hecho de que se relacionasen con este género en particular, y no con el realismo o con la "novela sentimental" y las representaciones dominantes asociadas con el romanticismo, indica el carácter transgresor del gótico femenino, que desde sus comienzos distorsionó los ideales patriarcales, entre ellos, significativamente "la posibilidad de provenir de Dios" (Fleenor 9).

De hecho, el gótico femenino comienza a diferenciarse formalmente como género en oposición a los ideales de la novela sentimental y del gótico temprano, donde los principios morales y los estereotipos sexuales se correspondían con las exigencias y costumbres de la época. En el gótico tradicional la imagen de la mujer coincidía con el rol de educar y servir a los hombres, y aunque eran moralmente superiores, ocupaban un lugar de servidumbre. ${ }^{8}$ Por el contrario, las heroínas del gótico femenino ya no se reconocen en los términos maniqueistas del bien y el mal, sino que presentan una imagen fragmentada de sí mismas, tornando la ambivalencia exterior de esta dicotomía en una división más bien interna (11).

Esta ambigüedad de los personajes femeninos tuvo que ver, en sus inicios, con una imagen patriarcal superimpuesta, cuyos valores no reflejaban los de sí mismas sino los que se esperaban de ellas. El ser un mero reflejo del otro dio, pues, pie a una identidad

marginalizada del ámbito cultural, buscaron diferenciarse deliberadamente de la escritura que seguía una orientación patriarcal (8).

${ }^{8}$ La sumisión era un aspecto clave en la configuración de la personalidad de la heroína gótica del siglo XIX, ejemplo "de perfecta obediencia... y silencio indestructible" (McMillen Conger, 93). Incluso para la heroína Mary Shelley, Elizabeth, este ideal se complementa con el de la abnegación, en la que se descansaba su atributo más "encantador", "continually endeavouring to contribute to the happiness of others, entirely forgetful of herself" (Shelley 30 ). 
divida cuya narración no podía ser tampoco convencionalmente verosímil (12). ${ }^{9}$ La estructura epistolar y la multiplicidad de los narradores recrean a menudo este psiquismo en lucha con los valores absolutos, cuyo resultado es el sentimiento de estar bajo permanente amenaza, lo que Ellen Moers definió como el terror característico del gótico femenino, un "miedo psicológico" que linda con el paroxismo (Moers 90). En este sentido, el gótico como un movimiento de carácter rebelde y combativo que va en búsqueda de la libertad, desentendiéndose de todo tipo de control y disciplina, se aviene con la circunstancia de los personajes del gótico femenino, ya que representa este intento de parte de los personajes de liberarse de las convenciones, entre ellas la de asumir la sexualidad en sus propios términos (Fleenor 14). ${ }^{10}$

En este orden de ideas, el estatus unitario que se le atribuye a la mujer desde un punto de vista estrictamente patriarcal, de ser casta o impura, madre o prostituta, etc., define las dicotomías entre las cuales se mueve la heroína del gótico femenino y de las que busca deslindarse. Así, la idea de ser reflejo de la imagen del hogar se disloca completamente, y si antes el espacio cerrado de la casa servía para indicar la conciencia de la mujer en su totalidad, en el gótico femenino la casa se torna un espacio represivo, carcelario y alienante, impregnado de una "palpable sensación de arrepentimiento y tristeza" (McMillen Conger 92; Lutz 84). Si bien se vale del simbolismo espacial del gótico tradicional, la imaginería de los espacios en el gótico femenino se manifiesta de

\footnotetext{
${ }^{9}$ Para Frederike van Leeuwen la retórica de las escritoras del gótico femenino es inseparable de la conciencia que tienen de ser "outsiders" en la sociedad, fundamentalmente patriarcal hasta nuestros días (33).

${ }^{10}$ Según Deborah Lutz, el sentido de apertura que adquieren las representaciones de deseo erótico postfeministas proviene del gótico femenino (82).
} 
forma distinta, porque su atmósfera está cargada de "ansiedad por la seguridad del espacio doméstico", de miedo y de rechazo hacia sí mismas (Wright 19).

Para Lutz, el miedo de las protagonistas tiene que ver con el descubrimiento de la autenticidad y el estado de incertidumbre que eso supone: la singularidad de la existencia, el hecho de saberse completamente solo en el mundo (Lutz 84). De ahí que la heroína del gótico femenino entra en la casa con la intención de apropiarse de los espacios y dominarlos, e incluso se ve impulsada a explorar la violencia y el sufrimiento que la rodea (85). Las más de las veces, la heroína inicia su camino y se encuentra con el misterio de sus propios espacios interiores, su propia oscuridad, su "otro" (86).

Significativamente, Moers observa que las imágenes de auto-rechazo suelen representarse de forma monstruosa, lo cual relaciona el gótico femenino directamente con la tradición grotesca y el énfasis en las imágenes visuales de deformidad (Moers 101). ${ }^{11}$ Esto añade un rasgo particular a las heroínas del género, en tanto que ya no se sienten amenazadas por seres o situaciones invisibles, como las figuras del gótico convencional, sino por el estado de vulnerabilidad de un cuerpo cuya rara anatomía las hace fácil blanco de agresiones (Lutz 83). A este respecto, Terry Castle arguye que las escritoras del gótico femenino reniegan mucho más de su propia corporalidad y de la corporalidad de los otros que los escritores tradicionales del gótico, al punto de que prefieren la vida de la mente (o de la imaginación) a la vida misma (250). El sentimiento de disgusto hacia la femineidad o lo contrario, su reconciliación con el cuerpo, hasta la aceptación del andrógino como

\footnotetext{
${ }^{11}$ Las novelas de Djuna Barnes son un ejemplo clásico del gótico femenino del siglo XX que se esfuerza por articular el estatus de alienación de sus personajes por medio de la distorsión y de la exageración. Thomas Eliot en su introducción a Nightwood se refiere a las figuras como "a sideshow of freaks" (6).
} 
parte de su naturaleza, son todos tópicos que el grotesco y el gótico femenino comparten (248-9).

Esta relación con lo "monstruoso” en sí mismas revela otro vínculo significativo de la heroína gótica con lo sobrenatural y su relación con el ámbito demoníaco (McMillen Conger 102). En el gótico temprano, la protagonista tiende a huir de este mundo extraño aterrorizada, como si perteneciera a una esfera diurna en que toda esta atmósfera impregnada de miedos y deseos ocultos representa una amenaza. Pero a partir de Wuthering Heights el personaje femenino se presenta como un ser nocturno y bizarro, de carácter indescifrable (102). El sentimiento de ser perseguida, no por fuerzas externas sino por sus propias pasiones — odio, rechazo, venganza - coloca el espíritu de lo demoníaco en el corazón de la imaginación de la protagonista, quien a diferencia de las de las heroínas góticas convencionales es consciente de su lado oscuro (102). Esto se corresponde con una de las motivaciones más pronunciadas del gótico femenino, que es revelar estas fuerzas incontroladas de la mente, hacer "perceptible todo aquello que ha permanecido forzosamente oculto", "trying to make absence present, trying to draw out the darkness from the light" (Leeuwen 36; Lutz 82).

Semejante reconocimiento, aunque doloroso, produce sin embargo un alivio en el lector, quien ya no se ve obligado como en las lecturas del gótico tradicional a reprimir y denegar los impulsos negativos y encuentra, como la protagonista, una vía de liberación a la tiranía que le ha sido impuesta: el ser moralmente cabal y perfecto según los estándares sociales (103).

El gótico femenino puede considerarse, en efecto, como un intento por expresar el dilema del "deseo de ser autónomo y la realización de que ello es imposible" (Leeuwen 
38). Porque si en la literatura realista el personaje se siente amenazado y perseguido, preso en un mundo hostil de terror y extrañamiento, al borde de la locura, esta realidad no dura para siempre. La heroína inevitablemente despertará y volverá en sí a un mundo, si no amigable, al menos más racional y comprensible. En la novela gótica, sin embargo, "la realidad es un mal sueño, irracional y sobrenatural, hostil y extraño" (Leeuwen 36). ${ }^{12}$ En esta línea de pensamiento, el gótico femenino es, pues, mucho más que "el modo gótico que emplearon las escritoras desde el siglo XVIII para expresarse”, como afirmó Moers, ${ }^{13}$ ya que quienes se valieron del miedo y del peligro inherentes al género, supieron transformarlos y moldearlos de acuerdo a la condición marginal femenina, adaptando la estética gótica a sus propias necesidades expresivas.

\section{El gótico postmoderno}

Según Maria Beville, el género gótico postmoderno puede verse como un eco o reflejo del terror gótico que se vivió en los años que siguieron a la Revolución Francesa: una situación de ansiedad generalizada ante un mundo inestable, caracterizado por "la violencia, la desorientación, la pérdida de sentido y de fe" (Beville, Gothicpostmodernism 23). Ante la creciente sensación de aislamiento e imposición del secularismo, el gótico-postmoderno puede considerarse una "respuesta artística al terror que actualmente amenaza nuestro inconsciente colectivo como parte de nuestra cultura

\footnotetext{
${ }^{12}$ Esta es una instancia del gótico femenino, el misterio en que viven envueltos sus personajes, que viven en un universo cuyas reglas desconocen, lo que Simone de Beauvoir llama acertadamente el "misticismo" de la condición femenina (57).

13 "[T] he work that women writers have done in the literary mode that, since the eighteenth century we have called the Gothic" (Moers 90).
} 
postmoderna al miedo y al deseo mismo de terror como discurso que explora el lado oscuro de la realidad que "conocemos"' (24).

Desde el punto de vista del género del gótico postmoderno, el terror no es solo un rasgo característico del discurso político de nuestros días, sino una experiencia profundamente personal $(24,32)$. La sensación de estar aterrorizado se correspondería con un estado de suspensión en que la mente se distrae mientras descubre lo que ocurrirá después. El terror puede entenderse aquí como "un estado de alteración de la conciencia que, en un breve espacio de atención, nos permite captar aspectos fundamentales de nuestra persona" desconocidos dentro nuestro marco común de referencia subjetivo (24). Este momento está relacionado con la experiencia simultánea de lo sublime entendido no como un vehículo de trascendencia más allá del ser, sino como una emoción que "arrastra hacia adentro" (Morris 306).

Las investigaciones de Jean Francois Lyotard esclarecen este fenómeno. Lyotard asegura que lo sublime produce en el individuo un efecto de "heterogeneidad pura" que le permite existir por un momento más allá de la homogeneidad que gobierna la realidad que se percibe (210). Esto sugiere que la experiencia sublime del terror es una vivencia intensamente imaginativa, en que "la razón cognitiva y la objetividad se rechazan en favor de la fantasía y del deseo" (Beville, Gothic-postmodernism 26). Es relevante llamar la atención sobre el carácter único, atemporal e inmedible de esta emoción, en tanto que apunta a una experiencia totalizadora que no obstante raya en lo liminal, en una existencia que cuestiona lo real desde una conciencia marcadamente subjetiva (27). El gótico postmoderno puede interpretarse entonces como una vía de conocimiento del ser 
por medio del terror, que desestabiliza la realidad y la ficción en el momento sublime en que ideologías binarias se confrontan con lo irrepresentable.

De acuerdo con Edmund Burke, el mayor de los terrores es la muerte (86). En el marco de la postmodernidad, la muerte no es únicamente corporal ni subjetiva, sino que tiene que ver con la pérdida total de valor y sentido del sujeto, con una sensación de "disolución y vastedad" que remite a una existencia irreal e indefinible (Beville, Gothicpostmodernism 49). La manifestación más común de la muerte simbólica en la literatura gótica aparece representada por fantasmas o espectros (31). Estas figuras tienen de por sí una existencia indeterminada y purgatoria, comparables a las almas errantes del infierno de Dante. Pero en un contexto más reciente, estos fantasmas emergen de la cultura del terror y representan una existencia que linda entre lo humano y lo inhumano, caracterizados por la heterogeneidad o multiplicidad del ser. Sestas apariciones son, pues, los "otros" desconocidos y partes de la propia existencia marginadas y espectral del individuo. No es de extrañar, por tanto, que en ese retrato dispar y excesivo del sujeto que ofrece el gótico, su estética se perciba como una visión "saturada" (Hogle 287).

Esta construcción plural del personaje sugiere, según Fred Botting, que el mundo es ficcional en un sentido amplio, en tanto que toda identidad es un efecto de narrativa, una fantasía o construcción basada en deseos y emociones, más que en la realidad (Gothic 170). Efectivamente, la noción de terror que recorre la tradición gótica se sostiene en este principio: las cosas no son lo que parecen, las reglas societarias raras veces coinciden con la verdad. El aspecto laberíntico propio del gótico tiene que ver con la ruptura de este orden aparente y la irrupción de la incertidumbre y del miedo. En la ficción gótica esta ambivalencia o duplicidad produce una forma distintiva de reflexión 
que puede llamarse "ansiedad narrativa", característica de la postmodernidad, y que implica una preocupación cultural, a saber: las cosas no solo no son lo que parecen sino que su apariencia es propiamente lo que son, mas sin que haya unidad entre la imagen y la cosa (171) ${ }^{14}$ La inestabilidad que deviene de esta realidad sin basamento ni sostén produce así un "exceso de lo sublime" pero en un sentido oscuro, en que se disuelven todas las mitologías convencionales y dando lugar a una "fuerza extraña fuera de control" (171).

Botting califica precisamente de "excesiva" la escritura gótica (Gothic 1). Robert Miles, por su parte, apunta que el gótico "no es un género como tal (...) [sino] un escenario discursivo, un modo carnavalesco para representar al sujeto fragmentado" (Beville, Gothic-postmodernism 39). A este respecto, Julia Kristeva añade que la aparición de "monstruos" o de criaturas grotescas se introdujo en la ficción gótica con el fin de encarnar las contradicciones y ambigüedades de los individuos, representando aquellos obstáculos de índole subjetiva para crear una identidad coherente (39). Richard Kearny, en cambio, sugiere que tales monstruos le recuerdan al ego que nunca es completo ni "soberano" (4). Como sea que se contemplen estos personajes liminales, todos apuntan de una u otra manera a la otredad de las figuras, a "las voces (...) de lo inexpresable; lo irrepresentable" (Beville, Gothic-postmodernism 41).

Desde el principio, el gótico se asoció con un tipo de discurso deconstructivo en términos de oposición y confrontación: el mal y el bien, la vida y la muerte, hombre y mujer, el ser y el otro, pasado y presente, realidad y ficción, etc., con lo que el modo gótico siempre fue una vía discursiva para desplazar tales distinciones que existen cuando

\footnotetext{
14 "[N]ot a unity of word or image and thing, but words and images without things or as things as themselves, effects of narrative form and nothing else" (171).
} 
las oposiciones se presentan. Sin embargo, lo que distingue al gótico posmoderno del gótico moderno es el hecho de que tal disolución de contrarios se opera en el marco de la subjetividad, que tales oposiciones no son de carácter externo sino psíquico. Esto se asocia con el cambio de función que se opera del modernismo a la postmodernidad, cuyo énfasis epistemológico pasa a ser ontológico, con una tendencia marcada a la autoconciencia narrativa (McHale 9). Para Beville este rasgo es de suma importancia, ya que revela el empleo de la metaficción como medio de autoexploración, "radicalizando la búsqueda modernista del conocimiento de sí y, consecuentemente, reorientando la aproximación del lector hacia cuestiones ontológicas” (Beville, Gothic-postmodernism 46).

La autoconciencia o autorreflexividad en la ficción gótico postmoderna tiende a desplegar "múltiples niveles de auto-ironía" formando así un conjunto de "metadiscursos" que se oponen deliberadamente a los discursos dominantes de la sociedad, y a la literatura que se tiene por tal (Beville, Gothic-postmodernism 16). Dichos metadiscursos funcionan como ejes disruptivos de la religión, la historia, la cultura y la identidad, invirtiendo sus presupuestos mayormente vía elementos fantásticos. En este orden de ideas, el género funciona como un contradiscurso o "contranarrativa" de las mismas estructuras que conllevan al terror en la postmodernidad (Beville, Gothicpostmodernism 34).

Otra característica distintiva de la autorreflexividad en la novela góticopostmoderna se manifiesta por medio de la duda. Dudar, en efecto, constituye uno de los ejercicios centrales en las investigaciones epistemológicas y ontológicas, y en la narrativa postmoderna toma la forma de "lo fabuloso" (47). Según David Punter las disrupción más 
aterradora de estos relatos coincide con esta incertidumbre que generan por medio de lo que él llama "a certain sliding of location, a series of transfers and translocations (...) that aour sense of the stability of the map is (...) forever under siege" (51). Este doble sentido del espacio, como lugar y como subjetividad "dislocada", constituye la amenaza más pertinaz y emblemática del texto postmoderno, y se conecta con los tópicos recurrentes del gótico en el marco de la postmodernidad como la crisis de identidad, la fragmentación del ser, el lado oscuro de la psique humana (Beville, Gothic-postmodernism 53).

Fuera de estas relaciones temáticas, la manifestación del gótico en el marco de la narrativa postmoderna puede identificarse, para enumerar resumidamente, en el concepto de lo sublime experimentado por vía del terror, en el suspenso; lo sobrenatural; la metamorfosis; el grotesco; la otredad; identidad fluida, fragmentada, la obsesión con la muerte o el fin (muerte simbólica), todos tópicos asociados con la experiencia de lo irrepresentable. En este contexto se desarrolla la primera novela de Somers, La mujer desnuda, cuya protagonista sufre una metamorfosis por medio de la auto-decapitación. Esta experiencia terrible dará paso, sin embargo, a admitir la otredad o aspectos marginados del ser como parte integral de su vida, desdibujando para siempre los límites entre la vida y la muerte, lo real y lo sobrenatural. 


\section{Capítulo 2. Del modernismo expresionista al gótico postmoderno: "La mujer desnuda" (1950)}

Se ha dicho que la primera novela de Armonía Somers, La mujer desnuda (1950), encierra las claves simbólicas del universo de su narrativa (Villamil 1239). Esto es, en rigor, cierto, si observamos cómo la obra prefigura los temas y la singular semántica textual que Somers desarrolla y profundiza ulteriormente en sus cuentos y novelas; si logramos, asimismo, delinear las bases de las orientaciones literarias que sirven de fuente a la poética harto huidiza e "indescifrable" de Somers. Las tendencias que la crítica ha señalado con especial énfasis en La mujer desnuda han sido la llamada "narrativa imaginativa" propuesta por Ángel Rama, emparentada con la línea secreta de la literatura uruguaya, la poesía del Conde de Lautréamont; y, subvertida a ésta, o bien de manera autónoma, la literatura fantástica propuesta por Ana María Villamil, seguida por M.

Olivera y otros. Revisadas estas formas literarias con mayor detenimiento es posible distinguir cómo la mezcla de elementos oníricos y simbólicos a menudo adscritos a una estética "imaginativa", expresionista-surrealista, fantástica y realista a la vez, apuntan a una narrativa que combina de manera exquisita aspectos del expresionismo y del gótico contemporáneo literarios, marco desde el cual la autora “conjuga la complejidad de una búsqueda estética con una reflexión filosófica y ética” y, en último término, la expresión de la vida individual e inaprensible de la psique humana (Martínez 78).

\section{Gótico femenino}

Resulta curioso que la anécdota de La mujer desnuda hasta ahora se haya colocado en desventaja con respecto al contenido simbólico y sentido profundo de la 
obra, pues, detalles concretos, en apariencia irrelevantes, sitúan a la heroína en un contexto específico que permite identificar la situación del personaje en el acontecer vital humano, y recordar, igualmente, el misterioso origen y la capacidad de impacto que las cosas más simples pueden esconder en el seno de una individualidad cualquiera. Así, el hecho de que se mencione la edad de la protagonista, por ejemplo, no es gratuito: Rebeca Linke ha alcanzado la madurez y es en ese punto en que se encuentra subrepticiamente "con lo que ella había imaginado siempre, a pesar de una secreta ilusión en contra: la nada" (Somers 14). De alguna manera el momento que vive Rebeca evoca el de las heroínas del gótico contemporáneo, ya que "Rather than young, inexperienced virgins, most of the heroines of the new Gothic are in their late twenties, early thirties", edad en que se acentúa justamente el sentimiento de opresión y de angustia que viven en medio de un entorno que ha cercado todas las posibilidades del desarrollo de su individualidad (Lutz 90). Muchas de las heroínas góticas añoran la infancia o prefieren no crecer, porque entrar en la mayoría de edad o edad adulta significa vivir el "dilema de estar entre el deseo de ser autónomas y la realización de que esto es imposible" (Leewen 39). Pero la situación de Rebeca se acerca aún más a la de la protagonista gótica cuando lo que ellas experimentan como un "limbo" en ese punto crítico de su vida en ésta se despliega como "la nada" (39):

El día en que Rebeca Linke cumplió los treinta años, comenzó con lo que ella había imaginado siempre, a pesar de una secreta ilusión en contra: la nada. ¿Y si no ocurriera nada entonces, se había preguntado más de una vez, ni para bien ni para mal, que siempre es algo?

El error, pues, parecía radicar en haberse impuesto aquella medida en el tiempo respecto a un hecho ... cuando lo que tendrá que suceder será siempre obra del zarpazo ciego ... . Y la fecha llegó, desde luego. Pero sin marca visible de día fasto, apenas como un aburrido bostezo de verano igual a tantos. La mujer lo miró en el espejo junto a su propia imagen. Un 
bello día; un bello rostro. Y desprovistos ambos de lo que hace memorables las cosas. (Somers 15)

La ausencia de trascendencia unida a lo que parece un hecho ineludible, casi dramático, sumerge la anécdota en la ambigüedad; luego, no se sabe cómo asumir el evento que abre la historia. Mientras la voz narrativa coloca el encuentro con la nada en el marco de un pretérito contundente e irreversible, con cierto halo trágico, la voz de la protagonista deshace la gravedad del estado poniendo en duda sus consecuencias y con ello la relevancia de tal situación. De un lado se coloca la "nada" en el lugar del hecho, lo cual vendría a ser lo mismo que decir "no ocurrió nada", y, del otro, valida la no-ocurrencia como un suceso no de índole fáctica y externa, sino de una realidad interior ("comenzó con lo que ella había imaginado siempre"). La "nada" se plantea entonces en esta doble acepción porque es invisible para los demás. Por fuera todo se muestra igual, "un bello día, un bello rostro", carece del festejo colectivo, de eso que otorga a las cosas la calidad excepcional de destino, "sin marca visible de día fasto (...) desprovistos ambos de lo que hacen memorables las cosas".

Esta naturaleza psíquica del acontecimiento se aparta desde un principio del talante narrativo realista cuando no se interesa en describir los porqués, en darnos un marco de referencia que sirva para explicar las causas. Y no obstante, los elementos realistas están de nuevo ahí para recordarnos que estos sucesos interiores cohabitan con los más comunes — un cumpleaños más, un día como cualquier otro-; que aunque son imperceptibles, ocurren ("la fecha llegó") y tienen, de hecho, consecuencias reales: "Había llegado quizás el momento preciso de que cada uno deba vivir su acontecimiento 
propio. (...) Y si se contabiliza un desgraciado año más, (...) el poder decidir qué se hará a partir desde ese entonces" (Somers, La mujer... 14).

Así, la eventualidad más cotidiana asume de pronto una dimensión radicalmente distinta, una profundidad simbólica donde las capas de significado van haciéndose más densas. ¿A qué se debe, por ejemplo, la expresión de "un desgraciado año más”? A primera vista, el relato aparece como algo inexplicable, porque la realidad individual que se plantea no resulta evidente en términos de un símbolo que podamos indagar en su relación con el mundo: ni la vida de Rebeca Linke, ni el estado de la nada se asocian con una imagen anterior, concreta o reconocible, más allá del suceso en sí. El lector queda, pues, desde el principio, a la expectativa de alguna explicación, del asomo de algún indicio que le permita penetrar en la existencia de Rebeca, pero esta explicación nunca se da.

Estamos, en efecto, ante un narrador que no es del todo omnisciente, que al igual que la protagonista emula un estado de consciencia atípico, lo que en el discurso se muestra como una continua reticencia. Efectivamente uno de los aspectos más llamativos al comenzar a leer La mujer desnuda es la reticencia con que se nos introduce el relato. La historia, que abre in media res, unida al laconismo de la voz narrativa y las contradictorias meditaciones de la protagonista que trasuntan el evento, pactan, por así decir, de entrada con el lector, en una apuesta por su complicidad inmediata en el asunto. Complicidad que se percibe con cierta violencia por lo que tiene de directo el mensaje, por presentarnos a Rebeca Linke sin mediaciones a través de sus pensamientos más secretos. Pero esta relación que se entabla con el lector no es distinta de la que el narrador tiene hacia Rebeca, ni difiere tampoco de la experiencia que el personaje está 
experimentando. David Punter señala que los personajes y narradores del gótico "[f]ar from knowing everything, (...) frequently know little or nothing about the world through which they move or about the structures of power which envelop them" (273). Es evidente que el intento por relatar una realidad interior, "la cual expresa en un nivel y en la complejidad de una intensa vivencia personal", como indica Rama, no puede coincidir con el método de narración realista, ya sea por vía del monólogo interior, que se mantiene al nivel de la consciencia despierta, ya sea por el del recuento de imágenes familiares o meramente alegóricas (Rama, La fascinación 9). Para Villamil toda la primera parte de la novela obedece a una historia "cifrada", cuyo contenido se capta en parte racionalmente, mientras que "otra parte nos es transmitida (...) a través de la imagen distorsionada del sueño (...), me estoy refiriendo a la esfera del inconsciente" (148).

De alguna manera, la textura subjetiva de índole onírica que se señala en la narración se aviene con el mismo objeto de que trata, es decir, las reflexiones más ocultas de Rebeca. Y es aquí donde el modo gótico se hermana de forma casi natural y a la vez única con el expresionismo, en que ambos contienen y parcialmente reproducen la dinámica de los pensamientos en sus capas más profundas, imitando la estructura y las figuras tal y como aparecen en los sueños. ${ }^{15}$ Desde esta perspectiva se comprende mejor la malicia con que el narrador calla los detalles que sobreentiende, la ambivalencia de la situación, pues ahí como en los sueños priva el deseo velado del personaje al tiempo que todos sus miedos, sus obsesiones y sus anhelos recónditos entran en juego.

\footnotetext{
${ }^{15}$ Según Sokel, el expresionismo manifiesta un estado interior complejo por medio de la arbitrariedad y libertad con que los seres se conducen en los sueños. De forma similar, "The Gothic is actually appropriated throughout as means of constructing psychological depth and intensity" en particular cuando estas historias "emerge within the more dreamlike parameters" (Punter 291-2).
} 
Gran parte del misterio que se atribuye a la originalidad del estilo de Armonía Somers proviene de ese tono reticente, de esta suerte de secreto que se nos participa sólo tangencialmente, como si se tratara de un lenguaje en clave que el lector ha de esmerarse en comprender. Esto se debe, como se mencionó atrás, a la omisión sistemática de las causas del evento —no sabemos qué vida llevara Rebeca hasta entonces, qué motivos tenía para imaginar la "nada"-, y, también, a la carga de sentido que por esa misma parquedad se redobla en las palabras, en los silencios que dictan las marcas de puntuación. Esta ambigüedad ha sido contemplada como la raíz de lo fantástico en $L a$ mujer desnuda, en donde "el contenido simbólico y meramente irreal (...) se dan al mismo tiempo" y donde la interacción de la realidad interior y exterior de la protagonista abre paso "a una tercera dimensión que podríamos llamar fantástica" (Rodríguez Villamil 147). Sin embargo, observados más detenidamente, el tono del relato y la forma de presentarnos a la protagonista no producen estricta "vacilación", condición sine qua non del género fantástico, sino, más bien, una suerte de desconcierto moral ante la expresión directa del acontecer psíquico del personaje que admite deliberadamente una circunstancia "desgraciada" sin el pudor propio de la conciencia (Todorov 19). Al menos esa es la impresión que se tiene cuando el narrador aclara seguidamente cómo empezó ese estado:

que ella fue retrocediendo inconscientemente en un escenario vulgar y desapareciera de la vista. Había llegado quizás el momento preciso de que cada uno deba vivir su acontecimiento propio. Si es un velatorio el de estar vivos junto a quien precisamente ya no podrá repetir el ensayo. Y si se contabiliza un desgraciado año más, (...) el poder decidir qué se hará a partir desde ese entonces. (14) 
Esta vez citamos el fragmento completo para subrayar el carácter adusto de las cavilaciones de Rebeca, su contemplación despiadada de sí misma. La sinceridad inusual con que imprime su propia imagen se muestra sin el velo embellecido o consolador del flujo consciente. Aunado a esto, la primera frase nos da una clave cuando refiere la vuelta hacia "un escenario vulgar". Villamil observa este retroceso como un umbral a la aventura fantástica por la ambigüedad que bordea el asunto, porque puede implicar un mundo real o una fantasía del personaje, o bien un viaje de la conciencia sola (150). Pero este ir de Rebeca en pos de un ambiente ordinario, más allá del cariz fantástico que pueda asumir, tiene más sentido si, siguiendo el postulado expresionista, se ve como la urgencia de quien persigue la vida común y corriente exenta de cuestionamientos, en un anhelo por deshacerse del excesivo cerebralismo y las formas aprendidas de la conciencia, lo que se ha llamado la tendencia del vitalismo expresionista. Igualmente, no hay que olvidar que un hecho se considera exclusivamente fantástico cuando los mismos personajes dudan del acontecimiento del que son partícipes y, hasta ahora, Rebeca no sólo está al tanto de lo que le ocurre sino que opta por darle validez a su "acontecimiento propio", se concede a sí misma "el poder decidir qué se hará" a partir de ese punto. ${ }^{16}$

Por tanto, no nos resulta tan curioso que "la nada" que experimenta el personaje vaya unida a una necesidad de resolución — “el poder decidir qué se hará a partir desde ese entonces"-, de cierto movimiento psíquico que la saque de este compartimento estanco como el estar en un perenne velatorio, pues ello tiende a ser la norma en el contexto de las emociones, su ser variable. Lo extraordinario aquí es que sea ella misma

\footnotetext{
${ }^{16}$ Para Tzvetan Todorov, aunque existen excepciones, "La vacilación del lector es (...) la primera condición de lo fantástico. (...) es necesario que la vacilación esté representada dentro de la obra. La mayoría de los textos que cumplen la primera condición satisfacen también la segunda" (19).
} 
quien se coloque como testigo de una muerte que en realidad es suya, que es ella quien vela y está muerta al mismo tiempo. En esta situación de testigo de sí misma, especie de desdoblamiento, ¿acaso no asoma cierta perspectiva objetiva? Es decir, el estado onírico en que se desenvuelve no le resta lucidez, sino que la acentúa y le otorga esa distancia que le confiere a las cosas un contorno más nítido, que en este caso es el de su propio vacío. $^{17}$

Deducimos que parte de esa decisión que toma Rebeca tiene que ver con su llegada a una finca. La lejanía del lugar, el carácter impersonal y vago del espacio, junto con el detalle de su llegada a "medianoche", preparan una atmósfera típicamente gótica, tanto más cuando poco después se relaciona con la entrada a una casa (Leewen 41). Este momento archisaturado de significado en el gótico tiene que ver con la aproximación al enigma, al "misterio puro (...) que está por revelarse y que debe ser puesto al descubierto" (Lutz 83). Mas aquí es fácil ver cómo esta cercanía a lo oculto, en el umbral de una posible revelación, se combina al mismo tiempo con el deseo típicamente expresionista de reproducir un universo en que las leyes de la causalidad y las relaciones están suspendidas amén de expresar una "situación invisible" (Sokel 38):

La finca a la que llegó en la medianoche se hallaba para la mujer algo así como suspendida en la atmósfera. No le conocía aún mayormente sus interiores. (...) Hacia adelante, un campo extenso. De pronto éste se interrumpía por una oscura mole transversal que iba terminando en forma de animal marino. Sí, realmente, el bosque siempre le parecería desde el principio un cetáceo varado. En un solo día de viento en que le fuera dado verlo, le había conocido en la locura, una especie de rabia impotente como la de ciertas formas ancladas de rebelión humana. Se movía sin abandonar

\footnotetext{
${ }^{17}$ Villamil, en su artículo "Bajo el signo de la madre: El despojo y El derrumbamiento", observa que "A través de procedimientos que apelan fuertemente a la sensibilidad, la escritora nos hace partícipes de una experiencia que salta las barreras racionales y se convierte en una extralucidez" (120). Para Noelia Montoro Martínez La mujer desnuda es "un intento de lucidez llevado a cabo mediante la creación literaria y surgido del torrente inconsciente y lo onírico, tejido todo con magistral vocación de construcción arquitectónica" (222).
} 
el sitio, (...) Pero no más allá del propio espectáculo de esclavo amotinado. (Somers 15-6)

Si leemos el fragmento en clave gótico-expresionista nos damos cuenta de que la descripción del espacio es un intento por proyectar el mundo interior que ha enunciado desde el principio, con la novedad de que ahora admite un algo inexplorado ("no le conocía mayormente sus interiores"). El bosque, imagen representativa de toda aventura insospechada, asociada al inconsciente, se presenta como un "cetáceo varado", es decir, como ella misma, en situación estática. La rebeldía que se insinuara ya en la edad de Rebeca como punto de inflexión se define más agudamente con la imagen del viento, algo que ella describe como una "rabia impotente". ${ }^{18}$ Hay toda una red de imágenes rabia-rebelión, esclavitud-amotinamiento_ - que indican la opresión y el afán de liberación inminente que se gestan en ella. Pero esta dirección que toma el psiquismo de la protagonista no es, como podría creerse, destructiva, porque inmediatamente se asocia con la imagen consoladora del río:

Porque había también eso, un río sin nombre, al menos para ella, que iba siguiendo al bosque separado por una franja brillante y clara, no sabía aún formada de qué, si de hojas o de arena, quizás también algo que tuviese el color de su propio vacío íntimo. (Somers 16)

La relación de lo desconocido con la imaginería acuática sugiere en un primer momento una cualidad positiva de ese vacío que media con la rabia contenida del bosque, en vista de que las aguas son fuente de regeneración y matriz de toda existencia, "son los cimientos del mundo entero, (...) la esencia de la vegetación, (...) fuerza creadora, y son

\footnotetext{
${ }^{18}$ En su tesis inédita, Ecos góticos en la novela y el cine del cono sur (2009), Nadine E. Olmedo observa la edad adulta de Rebeca no como un rasgo de lo gótico, pero sí como un factor determinante en su partida al campo, momento en el cual "el personaje de Somers se rebela y huye al espacio más alejado física y simbólicamente de su realidad" (89). También una "rabia inútil" precede a ciertas escenas violentas del gótico femenino como parte de una rebeldía en contra del lugar que les ha sido asignado (Leewen 40).
} 
el principio de toda curación" (Eliade 178). De allí que cualquiera sea el sufrimiento o la carencia que padece el personaje, al asociarse con el agua, se prevé una disolución de esa pena por medio de una transformación a favor de la vida, si se tiene en cuenta que ellas son el receptáculo primigenio de los gérmenes, el origen de las formas vitales. Comienza a tejerse aquí, entonces, otra cadena de imágenes relativas a lo arcano, al devenir secreto que se opera en Rebeca a partir del bosque. Éste, que sugería algo así como las posibilidades y los deseos desconocidos de su vida, recordemos, terminaba ya en forma de "animal marino", es decir, un emblema de las profundidades del océano, donde todos los seres "están imbuidos de la fuerza sagrada del abismo" (Eliade 195). Sin embargo ahora el mismo que se vislumbraba "varado", con la aparición del río, su visión estancada empieza a fluir.

Continuamente el relato insta a un tipo de lectura que, de acuerdo con David W. Foster, podríamos llamar "intelectual" pues su manifestación expresionista "nos lleva más a la contemplación de la psique humana que a una experiencia emocional”, si, efectivamente, observamos que se trata de un intento por visualizar —a la par de los personajes y del narrador - la relación subterránea, múltiple, de emociones-símbolo cuyos ecos son innumerables entre sí (10). Las alusiones del narrador parecen subrayar esto cuando dice que "la verdad del paisaje" estaba "en otro orden de cosas menos tangibles". Sucesivamente hay llamadas en el texto a sintonizar la lectura con el mismo esfuerzo del narrador por hacer "visible lo invisible" o, lo que es igual, por "hacer presente lo ausente", presupuestos en que el expresionismo y el gótico claramente fraternizan (Sokel 38; Lutz 82). 


\section{Terror sublime}

En este orden de ideas, tiene sentido cuando se habla de la presencia de un rito de iniciación en La mujer desnuda, en el despliegue de lo que se muestra como una serie de imágenes que confrontan al personaje desde su interioridad y frente a las cuales éste se resuelve a recrearse en ellas o no a fin de encontrar un camino propio e individual. ${ }^{19}$

Siguiendo el prototipo de las heroínas góticas, Rebeca Linke empieza su iniciación en ese viaje en ferrocarril a la finca, más propiamente al adentrarse en la casa que adquirió allí: ${ }^{20}$

Y fue así como entró en la casa aquella noche, completamente despojada de todo vínculo anterior, y casi con la sensación de un regreso a la matriz primitiva, desde donde se podría volver alguna vez, pero ya con infinitas precauciones (Somers 16).

La iniciación se opera, como es de esperarse, de noche. Ello se aviene bien con la revelación o transformación que a todo evento epifánico sucede, el cual se presenta en muchos casos como un despertar. En la traducción que hace J.L. Borges de $L a$ metamorfosis de Kafka, la primera palabra es “despertó Gregorio Samsa...”, y unos siglos atrás, también Lázaro, en El Lazarillo de Tormes, de un golpe contra el toro "despertó" en el sentido de que a partir de ese momento se supo solo y que tenía que valerse por sí mismo. El despertar que en Rebeca va acompañado de un "corte" con "todo vínculo anterior" aparece también en Lazarillo, cuando abandona la niñez al servicio del ciego y, más aún, en Samsa, una vez que amanece, sin más, transformado en insecto, exiliado sin remedio de su realidad previa. En ellos como en la protagonista este corte

\footnotetext{
${ }^{19}$ Para Olmedo "el viaje (...) funciona como metáfora de esa búsqueda interior que provoca en definitiva el autoconocimiento" (98); y para Villamil el rito de iniciación empieza "en el momento exacto en que ese viaje viaje en tren la deja en medio del campo. (...) la casa como representación de la interioridad del personaje, (...) que está por comenzar también un viaje interior" (153).

20 " $[\mathrm{T}]$ he primary defining trait of female gothic is the consistent focus on the heroine and the house (...) [where] the typical plot of confinement and escape (...) [leads] toward psychic individuation" (Punter 280).
} 
inevitable con el pasado, trátese de la memoria personal, de las convenciones sociales o de la realidad que hasta ese momento privó en el personaje, no implica sin embargo una ruptura con el cuerpo o con los registros con que él cuenta para darnos su propia versión de los hechos. Por el contrario, la reconexión con esa parte instintiva a favor de una percepción integral del sí mismo es crucial. Recuérdese cómo en Lazarillo el hambre era aviso de un apetito psíquico; cómo la sensación de temblor mecánico de las piernecillas de Samsa y el caparazón terminaron por advertirle que estaba fatalmente postrado si no se ingeniaba una estrategia para llegar hasta la puerta y poder al fin "abrir" la recámara. El cuerpo siempre refleja necesidades de corte psíquico. De ahí que esta especie de desmemoria "con la sensación de un regreso a la matriz primitiva, desde donde se podría volver alguna vez, pero ya con infinitas precauciones", no debe entenderse en Rebeca como un regreso al mundo primitivo literalmente, sino como la re-conquista de un tipo de cautela que la misma iniciación provee o despierta y que está, ciertamente, desde el legado picaresco, asociada a la sabiduría instintiva original, esa que el hombre moderno con el tiempo ha rezagado y ha convertido en la parte más reprimida y repudiada de la civilización occidental (Somers 17; Sucre 343).

Por eso no extraña que Rebeca lo primero que haga al entrar a la casa de campo es desnudarse. La desnudez física y concreta se alía con una necesidad de librarse de otro tipo de ropaje, como el "rayado blanco y negro con que la luz lunar filtrada por la estera uniformaba las cosas" (17). En ambas situaciones la desnudez parece querer deslindarse de códigos gregarios o autómatas, por esto de que las rayas "uniformaban" todas las cosas, y que en ella producen una sensación de agobio, cuando más adelante le urge desprenderse "de aquellos barrotes cerrando los ojos". Surge entonces aquí el motivo del 
encarcelamiento mental o prisión invisible, motivo que es también gótico y que remite de nuevo a la naturaleza interior del evento (Punter 53). Inmediatamente Rebeca entra en un "sueño hipnótico" que es muy revelador, porque dicho así se precisa que se trata de un estado y no de un simple sueño. El estado "hipnótico" rememora el viaje previo que la llevó hasta la casa de campo. Ahora se revelan detalles de esa travesía, como la voz insistente del hombre que pide los boletos:

La voz pastosa del hombre se queda entre las filas de los asientos como un cuerpo largo. Unos árboles a la carrera, el convoy que dispara en sentido contrario. (...) La gente sube, baja, se roba mutuamente el sitio. “¿No lo ha encontrado todavía?" La voz del hombre va a arrojarse nuevamente. Pero no hay esperanzas. Se vienen después las alambradas. Alambres, alambres tensos y ruido monótono. (Somers 17)

El viaje revela aspectos de sí misma con nuevos carices: la voz del hombre detenida entre los asientos como la situación de inmovilidad del bosque; el automatismo de la gente, la ausencia de esperanzas de un cambio, como el rostro en el espejo. El agua aparece otra vez como elemento movilizador y revitalizante cuando las palabras del hombre, seguidamente, se vuelven de pronto "remotas, y el hombre que las había pronunciado entre los hilos también, lejano y movedizo, como visto a través del agua y reatado por cuerdas de violines que venían vibrando de atrás de la vida" (17). Hay algo que pugna por surgir del fondo de las cosas, que se manifiesta también en la tensión de los alambres, vibrantes a la vez que ensordecedores, a punto de un colapso o transformación en algo nuevo. Esto se hace evidente cuando la voz del individuo de súbito "no sale ya del hombre, sino de los alambres" (17). Por virtud de la vibración vocal de la voz, la rigidez metálica de esos alambres (o voz del hombre) se convierte, nada más y nada menos que 
en ecos musicales, antes "cuerdas de violines": "El hombre quiso quitarse la música de encima con los dedos" (18).

El hombre encarna entonces un doble valor en Rebeca. De un lado, surge como una voz de agenciamiento o mediación en ella; alguien que, como apunta Villamil, exige justificación al “viaje” (154): “Perdone, señora, ¿puede darme usted el billete?”, “¿No lo ha encontrado todavía?", "Permítame, señora, que lo busque yo mismo. Sé que el billete debe estar en su bolsillo, junto a alguna llave" (Somers 17). Pero así como le recuerda que el "billete" — la respuesta— está en ella misma, también le advierte de los riesgos, por lo que es, igualmente, una voz de resistencia y de prevención: "Señora, yo no quería impedir su viaje... sólo que cuando uno adivina algo peligroso desea avisar, desplegar las señales de alarma..." (18). Como sea que interpretemos este personaje que aparece en el pensamiento de Rebeca, él actúa como figura colaboradora que disuelve las tensiones (la voz pastosa en agua, las tensas cuerdas en música), pues si en todo el pasaje la mujer se dice que "Nunca recuerda. Nunca recuerda", tras la insistencia del "hombrecito", finalmente ella "logró evocar (...) que dentro de su libro de cabecera había una pequeña daga que era una obra de arte, tanto como para decapitar a una mujer prisionera en aquel maldito rayado paralelo que le impedía encontrarse en limpio" (18).

La idea de que sólo cortándose la cabeza puede liberarla de su encierro es tal vez la premisa más atroz y a la vez más sublime de la novela. Señala la experiencia del terror sublime en la literatura de Somers, en tanto que los signos de una fuerte contradicción empiezan a abrazarse. Rebeca acaricia la imagen del crimen como un bien para sí, como una solución que le permitirá al fin "encontrarse en limpio". Que sea además una obra de arte la que cometa el acto, que se asocie la belleza de un objeto con una muerte horrenda, 
sugiere una decapitación magistral, como si se tratara de la preparación de un ritual sagrado. Este es el momento en que los críticos apuntan con mayor énfasis la confluencia de lo real y lo fantástico. Para Villamil la descripción de los detalles de la decapitación "es realista; pero el efecto y la atmósfera son fantásticos" (157). Más o menos lo mismo señala Olivera-Williams cuando refiere que la novela "abre con un acto simbólico y al mismo tiempo real" (32). Efectivamente, a partir del hallazgo de la daga todo el ritmo de la narración se acelera, las escenas adquieren una coloración fantástica una vez que las imágenes toman el lugar de los hechos y trastocan por completo las expectativas del acontecimiento. Es el caso, por ejemplo, de los objetos, que cobran vida propia mientras que las partes del cuerpo muerto conservan su autonomía:

La mano que quiere alcanzarla no puede. Derriba el vaso con agua de la mesa y queda allí como una flor congelada. Es entonces cuando la daga va a demostrar que ella sí sabe hacerlo, y se desplaza atraída por las puntas de unos dedos. (...) El filo penetró sin esfuerzo, a pesar del brazo muerto, de la mano sin dedos. Tropezó con innumerables cosas que se llamarían quizás arterias, cartílagos, huesos articulados, sangre viscosa y caliente, con todo menos el dolor que entonces ya no existía.

La cabeza rodó pesadamente como un fruto. Rebeca Linke vio caer aquello sin alegría ni pena. (18)

La garantía de la realidad del cuerpo, su lógico ensamblaje, se pone en duda llevándolo al absurdo y barajando siempre un sentido más profundo, como la fragilidad de todo lo que damos por fuerte y consistente: "Una cabeza, algo tan importante sobre eso tan vulnerable que es un cuello" (18). Con todo, más desconcertante nos parece la insensibilidad de Rebeca. Presenciamos el punto cúspide del acto criminal y no obstante el crimen está exento de dolor físico y aun de sentimiento de duelo hacia sí misma. En realidad se trata de la misma insensibilidad que ella viene mostrando desde el principio de la historia, sólo que ésta vez esa emoción se torna evento. Por eso la manifestación de 
rasgos fantásticos en La mujer desnuda parece estar subordinada a una narrativa expresionista, en el sentido de que estas breves escenas de gran impacto visual apelan a emociones del personaje que encuentran su mejor expresión en imágenes-símbolo, concentrando toda su fuerza en un atributo estético, como es esa daga que "era una obra de arte" (Sokel 43).

De forma simbólica y real, esa daga es también Rebeca, lo mismo que la "flor congelada" de su mano. Son imágenes análogas en su dureza, las cuales apelan a su ser comprimido, aún paralizado. Ambas son metonimias que buscan expresar una imagen del sí mismo "por vía de la exageración”, pero que no por ello dejan de ser reales (Sokel 39). El hincapié en la descripción del evento así lo confirma. N. Montoro Martínez asegura que el "detallismo de esta imagen descrita sin obviar el realismo de todo lo que la daga corta a su paso fomenta la sensación de realidad y no de sueño o de divagación de Linke" (223). No es, por consiguiente, la ausencia de verosimilitud lo que más extraña, sino, como se apuntaba atrás, el hecho de que lo bello se amalgame a lo terrible, que Rebeca al fin encuentre un algo excepcional en sí misma en la forma de un arma y de una violencia que asociamos con una muerte cruenta, sanguinaria. El proceso iniciático hacia la conquista de su individualidad invierte aquí los términos del modelo típico de la búsqueda interior; en lugar de iluminar los signos más evadidos y ennegrecidos del alma, de completar enteramente su sentido, se persigue exactamente lo contrario: "extraer de la luz la oscuridad" que despiden esos signos, perseverar en su misterio, en su naturaleza oscura original (Lutz 82). La decapitación inaugura el gusto por lo inexplicable, personifica cierta necesidad de ausencia de cuestionamientos, de búsqueda de un porqué o de una duración determinada para todo: 
La mujer sin cabeza quedó extendida sobre la alfombra oscura, pesadillescamente estrecha, de su último acto. Habría, bien pudiera ser, una dimensión en el tiempo para eso. Pero la conjetura más simple debía ser por entonces de alcance corto. Al tocar la garganta se acababan las preguntas. (19)

El terror del episodio se contrarresta asimismo porque, como señala Villamil, se muestra extrañamente de forma poética (159). En la escena que imaginamos de forma escalofriante, Rebeca está llena de vitalidad, incluso parecía que "su cabeza, la inexistente, le estuviera rebrotando en una forma dulce y liviana, especie de amapola en sazón de semilla" (20). Por primera vez las imágenes denotan algo vivo, prometen su movimiento natural justo cuando ella está literalmente desahuciada. De hecho, poco después de cercenarse, Rebeca ve, significativamente, rodar su cabeza "pesadamente como un fruto" y una vez que logra al fin incorporarse y alcanzarla se refiere de nuevo a ella en "la pesantez de fruto de la carga", apuntando ya a algo nuevo que ha nacido, "como algo que hubiera encontrado su verdadera esencia en el crimen" (20).

Junto al placer del acto logrado, aparece también, no obstante, la inevitable herida, "la conciencia de culpa", la tristeza (20). Tal parece que ese "fruto" nacido de sí misma le provee justamente de lo que hasta este momento le ha faltado: el sentimiento de pérdida, el duelo que se echaba de menos al comienzo. Con el dolor comienza a gestarse en la mujer sin cabeza una compasión que antes no existía. Sólo cuando esa cabeza asume una personalidad y características propias, cuando la percibe como un ser ajeno, Rebeca se compadece ella:

La pieza cercenada persistía en sus mutaciones, agregándose esta vez una personalidad retadora. Mirada desde nuevos ángulos, quizás gustase más a la mujer su última versión (...). Soliviantada y arisca (...) la muñeca sin tronco parecía desafiarla con su insólita metamorfosis. Un raro 
sentimiento equívoco comenzó a dominarlas. Se arrodilló, quedó a la altura de la otra. "Amanda, quiero besarte", logró decirle. Pero no pudo consumar el acto. Su boca irreal la invalidaba como en las pesadillas. (201)

La imagen terrible del cuerpo mutilado acercándose a esa cabeza mortalmente empalidecida es el cuadro que enmarca el primer destello de amor de reconocerse en sí misma. Es una imagen insondable en el sentido en que se evoca en Los Cantos de Maldoror, cuando Rebeca, de la misma manera que "el futuro ahogado" de los Cantos, se satisface en prolongar su vida al borde de la muerte o en lo que Lautréamont llama los "torbellinos del abismo" (Lautréamont 170).

\section{Lautréamont y no Kafka}

La influencia de Lautréamont en la literatura de Somers comienza a apreciarse aquí con más fuerza en el factor sorpresa, lo que Bachelard denomina la agresión del momento "duccasiano", esa que está presente tanto en el instinto como en la inteligencia y que actúa de forma corrosiva, atacando el problema (85). ${ }^{21}$ Rebeca consigue cortarse la cabeza en la inmediatez de un instante para librarse del rayado que la enerva, igualmente que ahora, cuando, ante al terror de la hemorragia, se coloca la cabeza "de un golpe duro como un casco de combate" (21). Esta forma de producirse la metamorfosis en la protagonista, de cristalizarse en un acto energético de una sola vez, es precisamente lo que distingue el tipo de metamorfosis de Lautréamont (Bachelard 6). Podríamos decir

\footnotetext{
${ }^{21}$ Bachelard "insists that poetic consistency depends upon a complex: 'In point of fact a poetic work can hardly be unified except by a complex'. (...) Bachelard stipulates that Ducasse's "madness" —or geniusis not random. (...) Bachelard labels this complex "Lautréamontism" and (...) pinpoints the "complex of animal life", which he calls "the phenomenology of pure aggression", that he finds in the work of Ducasse. For example, Bachelard draws revealing parallels between an animal and the human psyche - the human is as eager to strike out as is the animal in the jungle to seize its prey-. Animal cruelty slashes its victim blindly, ignores all prior relationship, invalidates previous feeling" (Stroud xi).
} 
que esta violencia que caracteriza la metamorfosis ducassiana comparte con el expresionismo la forma de percibir el mundo desde la visión, pues se dice que Rebeca vuelve al mundo "por los ojos". Tras colocarse la cabeza transfigurada, en Rebeca pareciera se "reemplaza el análisis intelectual por la visión directa" sin transición (Sokel 38).

Montoro Núñez observa en la obra Ducasse la "confluencia de lo onírico y la lucidez" porque ahí como en la novela de Somers se imprime el estado que emula la mente del que sueña, donde lo imposible (decapitarse y volver en sí, en La mujer desnuda, o abrazar a un tiburón y fundirse en él, como en los Cantos), "ocurre como un hecho fidedigno sin que ningún marco de referencia explicativo (...) se dé”, que es lo propio del expresionismo (222; Sokel 47). El reemplazo de pensamientos verbalizados por escenas agudamente visualizadas se percibe con cierta agresividad. Ya lo observábamos al comienzo de La mujer desnuda en situaciones emocionales que se articulaban directamente en metáforas, lo cual causaba un profundo desconcierto. Ocurre lo mismo cuando conocemos el personaje de Gregorio Samsa, que no se llama a sí mismo insecto, sino que se despierta como tal. Aquí es posible distinguir no obstante los grados de la violencia con que se opera la transformación, y aunque en La metamorfosis de Kafka participe del modo onírico expresionista y evoque la realidad del personaje en imágenes de gran impacto, la energía que sustenta el acto no es “devoradora” como en Lautréamont y Somers, sino más bien “moribunda” (Bachelard 6). Según G. Bachelard,

Para el autor alemán pareciera que la metamorfosis es siempre una desgracia, una caída, un letargo, un desfiguramiento. Se puede morir de una sola metamorfosis. En mi opinión Kafka sufre de un complejo de Lautréamont que es negativo, tenebroso y negro. Prueba de mis 
investigaciones sobre la velocidad poética y la abundancia de temporalidad tiene importancia, porque éstas en la metamorfosis de Kafka aparecen cándidamente como una retardación de la vida y de las acciones. (...) Samsa vive en un tiempo sin futuro. Las formas son estériles (...) porque el deseo de vivir está exhausto; éstas se multiplican en Lautréamont porque el deseo de vivir allí es más bien incitado. $(6,9)$

En esto yace la diferencia fundamental entre el expresionismo de Kafka y el de Somers, que mientras los personajes del primero sufren un profundo desvalimiento ante la vida bordeando la parálisis, las figuras de Somers tienen la urgencia de reapropiarse de la vida, de explorar la violencia y el dolor en que habitan y adueñarse de esos espacios (Sokel 84; Lutz 84-5). En este sentido el modo gótico se aproxima mucho más a la agresión ducassiana, en que el comportamiento agresivo y cruel funciona como un principio dinamizante en los personajes y no como un efecto retardatorio. Uno puede decir que $L a$ mujer desnuda adopta entonces la visualización inmediata y reproducción de la figura onírica del expresionismo de vanguardia, pero el ímpetu instintivo que la mueve y la actitud provocadora que la caracteriza, es gótico-postmoderna y ducassiana.

Hasta cierto punto el personaje de Rebeca Linke reelabora el prototipo de la protagonista gótica moderna, cuya representación más fiel hallamos en Catherine Earnshaw, figura principal de Wuthering Heights de Emily Brönte (1847) (McMillen Conger 91). Con Catherine la heroína gótica sumisa y abnegada, típica de los comienzos, se transfigura para internalizar dentro de sí la ambivalencia del bien y del mal. Esas polaridades existen por igual en Rebeca, con la diferencia de que para ella dejan de representar un conflicto: "ya no reincidiría en el apareamiento de las dos mitades contradictorias de sí misma" (Somers 20). 
Más aún, cuando la mujer desnuda sale después de recolocarse la cabeza, la imagen del campo ya no es una "oscura mole" sino un ser "con miles de ojos ocultos", pleno y dador de vida, y en donde "esa fuerte contradicción, de donde salía el verismo del objeto, era algo que estaba vivo bajo los pies, invadía el cuerpo llenándolo de mensajes" (23). Es decir, la contradicción incluso es saludable porque es fructífera. Esto se observa también en la imagen del bosque, que aunque le causa "pasmo" y sentía que "la estaba espiando", Rebeca ahora puede lidiar con él con más soltura y decisión, cuando se dice “soy tan real como ellos (...) sólo que más positiva” (23). Esta afirmación supone la integración o asimilación, si se quiere, de esa "aventura" en la oscuridad como parte más natural de su realidad. Esto lo da a entender de hecho en dos oportunidades, cuando se refiere a "su primera noche poseída" o a ser "poseedora de su propia noche" $(22,24)$. No sólo le es familiar sino que es lo propio de la vida para ella. La decapitación, que suponía ya el desmembramiento del aparato racional, del conjunto de experiencias que determinan la una percepción dada y que Rebeca asociaba a un estado sin memoria, refuerza con la metamorfosis la utopía o posibilidad de una vida que desacata sistemáticamente la ley de la razón. Por eso se coloca la cabeza como un "casco de combate", como para arremeter contra el razonamiento.

M.L. Femenías también ve en la afirmación individual de Rebeca "la expresión absoluta de la negación de la ley", pero hay que hacer la salvedad de que esta ley que viola Rebeca, que es la misma que desobedece Catherine Earnshaw y la mayoría de las heroínas góticas modernas, no implica una soberanía ilimitada del deseo personal a fin de un dominio societario (149). Rebeca no sufre esta serie de metamorfosis a causa de un mero capricho; simplemente ocurren, sin explicación lógica. Recorriendo el lugar, ella no 
puede denominar la causa, pero sabe que no es una veleidad: "ni siquiera uno que se arrancase de sí en un desplante individualista" (Somers 24). El leitmotiv del ensueño de su soberanía y de la transgresión del paradigma racional se rige, ciertamente, por "una voluntad decidida de ruptura con el mundo, [pero] para abarcar mejor la vida en su plenitud y descubrir (...) la realidad que niega. Es el despertar, la movilización propiamente dicha, de virtualidades insospechadas" (Bataille 38). Se explica entonces por qué la falta de memoria y la acusada "vuelta a los orígenes" que la protagonista percibe en sí misma, que luego se manifiesta también como una sensación de "nada". Sólo que ahora la "nada" es una distinta a la que precede la decapitación, pues esta le permite descubrir esas realidades inciertas que la habitan, posibilidades de sí misma en potencia, mucho más estimulantes que las preconcebidas. Por eso cuando Rebeca recuerda la profecía que alguna vez le anunciaran al leer la palma de su mano, (porque no pierde la memoria, sino que la contempla "bajo nuevas formas") vuelve

a mirar las líneas, [se queda] en la misma actitud del chico que no sabe leer y debe conformarse con las estampas del libro. Sin embargo le pareció encontrar algo que jamás había sospechado llevar consigo en sus propias manos. (...) Eran, en suma, experiencias de inventario minúsculo, pero capaces de sustituir el viejo miedo por desacatamiento absoluto de sus riesgos. (22-3)

Hay quienes podrían ver una nota insolente en esto del "desacatamiento absoluto de sus riesgos". La crítica tiene, en efecto, posiciones contrarias en torno a esta actitud de Rebeca. Para Montorio Martínez, por ejemplo, en la búsqueda de la identidad propia que persigue la protagonista priva "el horror, no la búsqueda de la belleza, ni la coherencia racionalista, sino la maldad más terrible, (...) en imágenes casi inconcebibles pero relatadas mediante una prosa plástica poética que se autorrecrea en la perversión y lo 
morboso" (222). Para Femenías, en cambio, “a Rebeca Linke sólo le queda el deseo (...) no se presenta como un personaje desgarrado, sino asombrado, inocente, ingenuo, dueño de un yo desamparado" (157). Ambas interpretaciones tienen razón, porque Rebeca es todo eso, $\mathrm{y}$, al mismo tiempo, no la tienen, porque el personaje no encarna esas cualidades de forma absoluta sino en expresión cambiante y diversa. No puede decirse que Rebeca actúe de forma inocente e ingenua, o meramente malvada. Al salir de su casa de campo está tanto asombrada como dispuesta a "desafiar el rigor de las zarzas" (22). Asume "prácticamente el rol detectivesco" cuando se infiltra en la casucha de unos leñadores (Lutz 85). En la corta travesía que la llevó hasta allí y en su "toma de iniciativa" demuestra una conciencia del absurdo carente de ingenuidad (Somers 24). Se trata de una sensibilidad peculiar que atiende a la violencia imperceptible del ambiente. Como la heroína gótico contemporánea, ella percibe la incomodidad del espacio doméstico, que parecía "tener preso el sosiego", y mientras se regodea en el juego respiratorio de la pareja, se describe "semiahogada como un insecto en las tuberías" (26). Esta rica imaginería animal que emplea continuamente la novela nos conduce de nuevo al valor biológico de los impulsos que se extiende a La mujer desnuda. Aquí, como en Lautréamont, la expresión "se asienta en un claro dinamismo de acción, un deseo de aprovecharse de todas las formas vivas para darle a sus acciones carácter poético, su causalidad formal" y nosotros añadiríamos, al arrojo de su comportamiento (Bachelard 86). Es posible que este gusto instintivo que se transmite en la acción instantánea remita a lo que Rama denomina el "efecto presentista” en la prosa de Somers, que es excesivo desde el punto de vista de su parquedad y embriagador por lo que tiene de "impulso espontáneo" de la infancia (Bataille 38). 


\section{Dos primitivismos}

En el encuentro con la pareja de leñadores la reivindicación de lo presente y la embriaguez del instante nuevo se manifiestan en los nombres que Rebeca se da a sí misma. Atraída por el vello del pecho de Nataniel, el leñador que duerme junto a la esposa, la mujer desnuda se presenta como "Eva, Judith, Semíramis, Magdala (...) Gradiva", arquetipos femeninos que apuntan a mujeres desafiantes y evocadoras de una libertad inusual. Pero Rebeca no las menciona para recordar sus historias míticas, sino para saber, dice a Nataniel "cómo seríamos en ti las mujeres que me habitan" (27).

De un lado el presente se expresa en la agresión del momento, de la visión transfigurada en acción, pero, del otro, aparece como una "reinterpretación del pasado de acuerdo con las preocupaciones del presente", en el sentido de una actualización de arquetipos que persigue más verdades presentes que pasadas (Lutz 82). Decimos "verdades" porque a Rebeca no le interesa conocer una premisa definitiva, sino sus múltiples, infinitas posibilidades. Por eso a la mujer desnuda le tiene al final sin cuidado la respuesta de Nataniel, "no necesitarías entenderlo", le dice, "debe ser todo más dulce de ese modo, sin completar su sentido..." (Somers 27). No sorprende en este punto que ella se cuestione al comienzo de su jornada el descubrimiento de su ser nuevo. Es de esperar que Rebeca esté ávida de saber qué hay de oculto de sí misma en esa "casa ajena" que es el otro — Nataniel—.

En cierta manera esta fase coincide con el motivo gótico de la "revivificación", si se atiende a que "la reanimación de la conciencia en los personajes góticos ocurre muchas veces a través de (...) heroínas" de antaño (Leewen 25). Acaso el narrador apunte a esto mismo cuando cuenta que en ese momento "la voz de la mujer salía cálida y blanda como 
ceniza recién formada" (27). Lo curioso es que este renacimiento nominal en realidad afecta más a los leñadores que a Rebeca, que son ellos quienes "reviven" a Eva en su propia visión de la mujer desnuda. La versión de Eva en el leñador es brutal: despierta sus instintos, pero no esos que se remontan a su naturaleza original sino al pasado bárbaro. Su visión es excesiva y no transgresora, a la manera de la mujer desnuda, cuya violencia de sus actos cobra valor y sentido en la medida en que "soluciona" aquello que confronta en su interior. Aquí la solución queda truncada porque no aporta emoción sino que se ancla en la idea fija, autodestructiva, rememorando la indolencia del hombre primordial:

el hombre continuaba en lo suyo, sordo y solitario preso en su red, sin más ley que la del angustiado forcejeo. Le era externo todo lo demás, incluso lo inerte y dolorido de la nieve que estaba hiriendo. No había ya lugar para la piedad. Sólo su especie de aniquilamiento a ciegas (...). Y todo eso como independiente de sí, más allá de sus propias decisiones, con la fatalidad de los declives. (Somers 30)

El primitivismo que caracteriza la "búsqueda de los orígenes" empieza a perfilarse entonces a través del contraste entre los personajes en distintos grados, lo cual puede asimilarse a las dicotomías que R. Cosse subrayara ya como una constante en la obra temprana de Somers. La diferencia más notoria entre el primitivismo de la mujer desnuda y el del leñador yace en la ausencia de imaginación. El amor "es tanto deseo de imaginación como imaginación de deseo", advierte Guillermo Sucre (344). Es llevada por el deseo de imaginar una aventura amorosa que Rebeca se cuela entre los esposos y acaricia a Nataniel. Mas en la tosquedad del hombre, su visión del deseo se trastoca en "aprensión" ante lo que se vislumbra como una regresión y no un renacimiento de sí. ${ }^{22}$

\footnotetext{
22 "Hasta que ella comenzó a sentir aprensión por la estúpida mezcolanza. Volvería a ocurrir lo de siempre, los bienes compartidos con miedo, el mundo del engaño y el robo, otra vez las inmundas ropas
} 
No en vano la pareja tiene "treinta años" de casados, la misma edad que el personaje, colocando el tiempo repetitivo, sin sentido de la pareja, en contraste con el tiempo de ella, ahora pleno de novedad y libre, como le anuncia a Nataniel tendida a su lado: "Ven, toca, estoy desnuda. Tomé mi libertad y salí. He dejado los códigos atrás” (27).

La rabia de Rebeca se contrasta asimismo con la del leñador. La de éste es producto de la frustración. Está "acosado" por su imagen. La choza, la almohada, el campo y todo su mundo es prueba dolorosa de que ella existe. Sin embargo, mientras más siente su presencia, más inaccesible se vuelve la mujer desnuda para él. En la mujer desnuda esa rabia se expresa, más bien, por medio de la provocación, que es igualmente ducassiana y que a partir de entonces se aúna al objeto de su travesía, ya que "lo que iba a contar de ahora en adelante como signo de la aventura no era la frustración de los demás, sino la intensidad con que ella les golpease en su impotencia" (32). ${ }^{23}$

Este humor cáustico acompaña al personaje desde el principio de la historia. Reaparece sucesivamente en distintos formas; primero como frialdad y vacío, como impertérrita rebeldía, y más tarde, tras la decapitación, como un desprecio hacia todo el universo clasificado, estereotipado, falsamente institucionalizado o deificado (la cultura, la modernidad, las formas societarias, Dios, los arquetipos femeninos, el matrimonio, la conciencia). Su metamorfosis, aunque marcada por el corte y recolocación de la cabeza, consta sin embargo de "pequeñas muertes", de incisiones, diría J. Kristeva, que se manifiestan con más relieve en los cambios sutiles de las metáforas y de los símbolos que

cubriéndola" (28).

${ }^{23}$ Mientras que Nataniel representa el prototipo del gótico masculino, donde la violencia "especially sexual violence, is dealt with openly and often in lingering and lascivious detail", la fantasía gótica de Rebeca está más próxima a la del gótico femenino, como se ve, pues "no se ocupa tanto de la violación (...) como del crimen" (Punter 278, Lutz 89). 
reflejan su interioridad. Estas imágenes aportan humanidad a Rebeca y suavizan su impresión asqueada de los habitantes del pueblo, como ocurre con el incidente de los leñadores. Cuando la mujer sale de la choza y reemprende su recorrido, el ruido del agua termina "reconquistándola", es decir, devolviéndola a la naturaleza que le es más afín, con la que ya ha venido dialogando a lo largo del relato (Somers 32). Sólo después de escucharlo puede rememorar "el episodio del leñador, la belleza madura e ignorada del hombre, los cerrojos en que viviría aún sin considerarse prisionero" con cierta compasión y hasta con sentido del humor: "rió abiertamente a causa del contraste" (33).

Más tarde, la propia aparición del río, aquél que la tranquilizaba porque carecía de nombre y estimulaba su curiosidad, ahora acentúa más bien su incertidumbre del futuro próximo. Además, ya no aparece sólo como río sino como "un personaje que reptaba a pocos pasos de su cuerpo (...) un largo ser vital acostado sobre su espalda, y sobrellevando eso tan solitariamente indescifrable que disuelve su médula" (33). Toda la descripción hace eco del mismo secreto con que carga el personaje, que por lo demás "se trepa" hacia ella, en peligrosa proximidad. La disolución, aspecto en que desde un principio coincidían, identificándose ambos, ya para disolver la tensión de un episodio, ya para prometer la eventual fluidez de la parálisis o del estancamiento, ahora se hace inminente. Antes era el río "sin nombre", ahora es ella quien iba "hacia un lugar sin nombre". El río anticipa el destino interior de la protagonista. Cuando la voz narrativa habla de él, a menudo se refiere a ella misma: "la seguía cada vez menos olvidado de sí, menos casto y desentendido que en el primer momento. Acusaba una especie de nerviosidad animal, un desasosiego doloroso invadido de cierto rehusamiento" (34). 
Los símbolos de la muerte

La forma en que las redes de metáforas se van distribuyendo en la novela da la impresión de establecer relaciones dialógicas entre pares comúnmente opuestos o irreconciliables. La ansiedad que delatara el río en Rebeca predice efectivamente la situación de peligro que se avecina, que ella asocia con el amanecer (la luz, la claridad). Llama la atención que justo después se tope con la imagen de la Virgen. La sensación de sentirse "descubierta", con ojos de la figura viéndola fijamente desde lo alto, se opone a la vigilancia del bosque, que pese al temor que le causaba, recuérdese, la colmaba de posibilidades, de vida que surgía del suelo y le subía por los pies. Un guiño hacia el antiguo rayado "que uniformaba las cosas" se asoma de nuevo cuando la protagonista protesta contra el nicho orientado "siempre hacia el mismo punto". Pero esta vez no es eso lo que más le molesta, sino la indiferencia, "la sonrisa perenne" con la que la virgen le daba la espalda a todo, "como si el sol, y la luna, y las flores no contasen" (37). Aquello de ser "menos casta y desentendida de sí misma” se muestra entonces en esta conciencia de la necesidad de integrar los distintos planos que configuran el mundo (luz, oscuridad, vida).

En esto, es posible que Rebeca esté apuntando a la misma necesidad que ella presiente con desasosiego, a esa agregación de 'inconsciente' a 'consciente' que se está gestando en ella, que es lo propio del proceso de individuación (Jung 333). Más adelante, en el encuentro con el caballo magullado por la atadura, ella le dice al liberarlo: ¿Por qué es uno tan incapaz de hacer esas cosas, o tan duro es el sistema?", preguntándose por la dificultad del alcance de esa perspectiva inclusiva que, como en ella, tiene que ver con 
la "desatadura", la liberación del animal. Todo el episodio está cargado de resonancias simbólicas que remiten a su propia conquista instintiva. El vacío de Rebeca, su insensibilidad estática aguardando la "nada", era como ese caballo enfermo "que había quedado allí, inmóvil, esperando no sabía qué, desconectado de aquel fluido interior como si le fuera desconocido" (39). Incluso el momento en que ella descubre la úlcera del animal y queda anonadada contemplando la succión de la mosca, el beso repentino que ella le da en la herida recuerda a la misma situación espasmódica del cuerpo decapitado observando absorto la hemorragia de la cabeza, que culmina también en el beso amoroso del rostro cambiado. La diferencia aquí está en que no es el asombro lo que la domina, sino el asco, "pero un asco que no alcanzaba a impedir que siguiera mirando" (40). Y al reconocer esto reaparece la connivencia de lo bello y lo horrendo, sólo que en un psiquismo más avisado, amistado, si se quiere, en la ambigüedad de su naturaleza: "Volvió aún a mirar el animal, en pleno goce del imprevisto. El ruido de sus dientes cortando el pasto era la única forma de atestiguar que el orden simple de los hechos estaba intacto, que ella no había desbaratado sus planes primitivos" (41).

En la celebración de su "amoralismo" que sigue a esto que parece la confirmación de la reapropiación de su destino, sin dioses ni virgen, sin oráculos ni más guías que la intuición original del sí mismo, se afirma acaso lo que la crítica del gótico moderno ha llamado el gusto por el mal, intrínseco al modo expresivo de la novela gótica, que se niega a "hallar respuestas aceptables en la religión a la cuestión del bien y el mal" (Hume 287). Este ascetismo de la novela constituye también para A. Rama la fuente del mal y del horror de los relatos de Somers, ascetismo que ronda la muerte "en su más precisa referencia a la descomposición" "con cierta delectación", y que, no obstante, participa de 
una profunda experiencia espiritual. Se podría pensar que el mal aquí pisa los terrenos de lo "abyecto", en particular cuando se habla de la confluencia del gozo y de la muerte en sus formas más repugnantes y dolorosas, si no fuera porque en la mujer desnuda esta experiencia va acompañada de amor y, acaso, por su misma proximidad a la muerte terrible, lo exalte confundiéndolo con la pasión más insondable. Es gesto amoroso el beso que da a su cabeza, a quien llama "Amada" ${ }^{24} \mathrm{Y}$ es pasión el beso incontrolado que da en la llaga abierta del caballo, "aquella clase de ofrenda que nunca hubiera comprendido en otros tiempos” (40). El cadáver, dice Kristeva, “—visto sin Dios y fuera de la ciencia— es el colmo de la abyección. Es la muerte infestando la vida" (11). Pero el cuerpo torturado que está a punto de deshacerse no contamina ni merma los deseos de vida de Rebeca, sino que le infunden un arrebato instintivo cuya fuerza vital la acerca más a la embriaguez dionisíaca que al sadismo.

Esta experiencia, por lo demás, va definiendo la imagen cada vez más nítida de lo que ella percibe como su naturaleza o destino interior, con lo cual la abyección, que suponía la "nada" del principio, aquel rayado subyugante que ella atribuye en parte a "la peste de su cultura" (los "esbozos de la cultura" que Kristeva asocia con lo abyecto y que son "las barreras" que "aniquilan" al individuo), se desvanece en favor de la imagen. Y la imagen es siempre fuente rica de posibilidades, de renovación vital, de autorreflexión y de cambio. Precisamente la ausencia de imágenes, de chispa de deseo imaginativo en la monótona vida de los leñadores era lo que distinguía el "primitivismo" de Nataniel con el instinto "original" de Rebeca, un espacio no menos vasto, decíamos, del que separa al primer hombre del ser humano.

\footnotetext{
${ }^{24}$ En la primera versión de la novela, publicada en la revista Clima, Rebeca Linke le dice a la cabeza: "Amada, quiero besarte" y no "Amanda" como aparece en la versión final.
} 
En este orden de ideas, lo abyecto en la novela parece estar, paradójicamente, en el pueblo, que aunque se plegaba al orden de la comunidad, vivía ajeno a sí mismo, en una secuencia repetitiva más absurda y titánica que la forma irreverente y procaz de la mujer desnuda:

en aquella sucesión vulgar de circunstancias, donde nunca ocurriera nada fuera de ordeñar las vacas y transportar los tarros al tren lechero, sembrar, casarse y tener hijos que harían después las mismas cosas, incluso ir el domingo a la iglesia, morir, continuar pasándose el apellido (...). (42)

Aspectos del mismo talante primitivo de los leñadores señalan además otras

desigualdades respecto al "primitivismo" de la mujer, como el aire personal de venganza que adquiere la población una vez que se "integra como un ejército bárbaro", preparado para arremeter contra una mujer desnuda que anda por sus praderas (43). El impulso individualista de Rebeca es decididamente personal, pero obedece a una necesidad interior que desconocemos, mientras que aquí el pueblo actúa gregariamente, por una motivación coercitiva externa y no propia. Así lo sugiere el narrador cuando delata el temor que "les iba mordiendo los talones, aunque sin impedir que las cosas prosiguieran su curso" y "el pequeño desastre íntimo de cada fantasía individual” que la imagen de “ella” empezaba a embargarles (43). La anécdota escandalizadora les brinda entonces la oportunidad de volver a sentir, aunque enturbiados por el miedo, una realidad distinta a la suya que, por lo mismo, les insta a mirarse a sí mismos. También el deseo aquí se vuelve deseo de imaginación y es por medio de ésta que revisitan su rutina desgastada a cambio de una vida nueva, en donde la sensualidad espontánea se muestra otra vez e vuelve insignificantes las faenas del día a día:

el hombre volvió a gustar, a mirar cada unidad de tiempo de un pasado que se había hecho humo de un día para el día siguiente, 
convirtiéndose en esa tarea mortal de gusano que pulula en el queso, siempre inmerso en el mismo olor, el mismo sabor, el mismo destino del otro que se produjo al lado. Hasta que un día viniera ella a las vecindades a traerlo todo de nuevo, a mostrar que el queso podía abrirse, aventar a los esclavos repletos, a mandarlos a hambrearse al suelo (...) si no había más remedio, pero aspirando, paladeando, viendo todo lo que ella, una mujer sin ropas que se pasea al sol, traería del paraíso. (49-50).

Pero no sólo Juan ensueña otra vida en la mujer, sino que todos, hombres y mujeres del lugar están absortos con la imagen de ella (Somers 51). De nuevo la visión interior se presenta como real y obstaculizada a la vez, semejante al caso del leñador, pues "ella era tan real como su pedazo de uña, pero inhallable" (47). Incluso el cura del pueblo, principio conservador de la comunidad, "se había dejado llevar sin lucha a ese interior desconocido, con un olor que le era nuevo y en el que su olfato no se le comportaba eficazmente" (53).

Extrañamente, el hombre que por vocación supone la mayor castidad es quien sufre, a la par de Rebeca, una suerte de "decapitación”. También aquí se subrayan las imágenes acuáticas y la atmósfera que caracteriza la figura de quien sueña, si bien es la luz y no el aire lo que predomina en su imaginería: "El hombre magro no se había adaptado aún a la penumbra semilunar del sueño. Pero la mujer desnuda lucía demasiado para que la devorasen las sombras, y su cuerpo iluminaba de por sí como una madreperla en la oscuridad marina" (53). Su lenguaje retrotrae la expresión del místico, que inventa toda una poética de la flor relativa al encuentro sagrado. Allí la mujer desnuda le pide su cabeza, que se la entregue a ella "ardiente y sola como una flor del desierto en esta noche para dos, dámela", pero su cabeza queda "flotando" y empieza a reproducirse en muchas como "círculos de agua". Hay en este paso de lo seco a lo líquido una especie de 
resistencia, de transición que no cuaja. El cura se ahoga con la imagen de ella. Tal vez por eso no logra ni entregársela ni recolocársela a sí mismo: "su unidad de cuerpo decapitado, no lograba apropiarse de ninguna, aun corriendo como un loco en su seguimiento" (53). Él hubiera querido poder atrapar "una sola" de sus cabezas, pero le fue inútil y a partir de entonces cae en la contemplación estática de la mujer desnuda. Esto es algo que el hombre virgen experimenta como aterrorizante y sumamente seductor a la vez: “(Dios mío, haz que mis párpados sean fuetes como las murallas de Jericó y que no los desplomen las trompetas. Pero no, no lo hagas aún, espera, deja que me derribe”) (Somers 54). Sin embargo, aun cuando la mujer se esfuma en el instante en el que él estaba ya dispuesto a poseerla, el cura ya no es el mismo. Se menciona también la palabra "poseído". Mas el tipo de posesión no es erótica, como en Rebeca, quien después de rendirse junto al leñador y sin llegar a consumar el acto amoroso ya no "se encontraba virgen de los ardores de su entrega". La posesión del cura es, más bien, mental, pues entonces "pensó, que el mismo autor de los aburridos arquetipos iba a componer el orden antiguo" (32, 55 la cursiva es mía).

La transformación que empieza a desarrollarse en los personajes del pueblo parte de una avivación de los instintos, de un reconocimiento que se inicia con la fantasía de una realidad desde el cuerpo físico y psíquico, y que las más de las veces reclama, como en el caso paradigmático de Rebeca, un desmembramiento. Decimos desmembramiento e ineludiblemente pensamos en sacrificio. El sacrificio de Rebeca es justamente uno que pide entrega completa de lo que hasta ese momento conformaba su ser, llámese ego, historia personal, fracasos, conquistas. En otras palabras, exige lo que más cuesta: la entrega de la imagen que ella misma tiene de sí. El amor que Rebeca siente hacia su 
cuerpo desde que "se desnuda", que es amor por su psique también, y va abarcando todo su ser hasta tocar, quizás, sus partes menos queridas por sí misma, sería la primera manifestación de la metamorfosis y el motor de ella (Rebeca se desnuda apenas entra a la casa de campo, previo a la visión distinta de sí misma). Pero en el pueblo, a pesar de que parecía que "hubiera cambiado de pellejo o mudado de aire" todos se engañan, y la imaginación del deseo destruye su imagen múltiple en la ejecución del acto brutal, mecánico, desprovisto de las formas del cortejo y la conquista, de todo el ritual que precisamente transfigura lo animal en sagrado $(57,46-8)$. No es casualidad que la homilía del padre sobre el Génesis se refiera a esa pareja primigenia en esos términos, como si se tratara de la misma circunstancia o, del mismo tiempo:

No existía aún el deseo, la posibilidad de la caricia. Debía entonces, ser la pura abstracción de la belleza lo que reinase. Puesto que no había amor ni su sombra hecha de pecado, los dos cuerpos desnudos e ignorantes de sí, recién paridos del fuego de Dios como cerámicas en único par ¿bajo qué formas podían pintarse, aun venerado fuese Michelangelo, con modelos comprometidos en el proceso que aquellos dos desconocían? (71).

Aparece de nuevo el correlato de Eva para reivindicar su imagen de fuente de vida, pero de una manera ambigua, porque la confunde con la mujer desnuda literalmente, es decir, con su propio deseo de poseerla: "ahora se sabe que Dios quería que comiera del fruto. Y la mujer desnuda está de paso por la aldea, en busca de la revisión del juicio. Y se burla de vosotros (...) incapaces de amor entero" (73). Las lúcidas apreciaciones del cura se precipitan entonces a una sospechosa confesión pública, "castigándose en el pecho" y "condenándose" por ella, como si se sintiera culpable y no aliviado (75). Su discurso se vuelve excesivo en el misterio de lo narrado, de lanzar tal vez brutalmente una verdad que tendría que dosificarse y expresarse, también, desde el interior de ellos para ser 
comprendida. El narrador en este punto llama significativamente "hombrecito" al cura, empequeñecimiento que entre jocoso y despectivo alude a la ingenuidad de su torpeza. Porque si en él se despierta el deseo de experimentar "el maravilloso pecado", su visión no pasa de ser un anhelo. No cobra realidad en su cuerpo porque en realidad lo desdeña, lo que se muestra por medio de una mujer que irrumpe en parto en mitad de la iglesia y ante la cual él muestra profundo desprecio: "Asco de mujer (...) venir a parirse aquí, justamente, en la casa divina" (76). No es, pues, la suya una lucidez como la de Rebeca, subjetiva, autorreflexiva, transparente en su honestidad hacia sí misma; sino racional, catequizante, meramente justificativa de lo que aún siente como falta. Su discurso, en apariencia brillante, es más bien una ficción idealizada que encubre odio, al igual que los habitantes que "odiaban a la desconocida, se odiaban a ellos y entre ellos" (77). Quizás este querer explicarlo u explicárselo todo, de poner en palabras lo que hubiera podido por ejemplo pintar, si había sido pintor, sea el error trágico del cura, que en su discurso se muestra como un una conciencia encandilada, y al final como fuego literal que arrasa con la vida, evocando la muerte única y prematura de los héroes o de lo que quiere ser heroico.

La embriaguez desaforada de padre, desnudo al final, falseando aquella otra en su literalidad, en nombre de un amor que, como vimos, no siente, es la contracara del amorpasión que en cambio sí se da entre Rebeca y Juan. La embriaguez de este encuentro cristaliza todos los aspectos emblemáticos del recorrido de Rebeca, que comporta aquí, si no un sentido completo, sí el clímax de su búsqueda. Del melancólico "Grisalba" se pasa a invocar el de "Friné", como si el ímpetu propio del lenguaje fuera el amor. En rigor "el 
amor es impulso por poseer, a través de las palabras, el mundo, así como el amor es el deseo de poseer al otro" (Sucre 344). El "efecto presentista" se acentúa en una imaginación del deseo que se actualiza de forma única, al punto de que para ambos la imaginación ya no va a ser igual a cualquier cosa que haya ocurrido en el pasado. Por primera vez el tedio, que caracterizaba las reflexiones de la mujer en torno a la unión de los amantes, todo ese marco de referencia inútil por lo que tenía de irremediable, desaparece por completo: "la mujer pareció sorprendida, como si la arrancasen de un estado amnésico" (93). Cuando iba a hablar, ella sintió que estaba "condenada a un mundo sin recuerdos" (94). Lo mismo que a Juan, a quién no se le ocurría nada "que pudiera interesarle de su pasado. Estaba tan en su hoy (...) que era toda una muestra de presente (...) quizás con algo de futuro" (94). La esposa y los hijos en la casa, todo se vuelve olvido y pasado remoto en presencia de "todos sus deseos", que era lo que más “ambicionaba antes de morir" (96).

El punto más elevado se alcanza en la imagen de la herida sangrante, que ya no está fuera de la mujer desnuda, como en las veces anteriores, sino en ella. Es la herida abierta del hombro de Friné la que funda la mitología de los amantes, porque ella propicia el encuentro y la transformación. Si antes era el asco repulsivo el motivo de la contemplación estupefacta, ahora es la sensualidad, deseo amoroso intensificado en la pasión individual, porque es compartida:

[Él] cayó con sus labios sobre la zona magullada, en una especie violenta de ritual salvaje en el que cada rincón de su ser parecía reencontrar los perdidos ancestros. El sabor de la sangre acabó de enajenarlo. Era como dejar de habitar su propio clima para lanzarse al primer golpe de viento quién sabría hacia dónde, como una semilla ciega en un verano desconocido. Y, sin embargo, entre su boca posada en aquella herida, tan semejante a un sexo de mujer, y el deseo por entrar en sus verdaderos 
labios, qué sensación de mansedumbre, qué dulce y misericordioso el acto. (97)

En el beso de la herida la fuente del mal se vuelve incierta, pues ¿qué es el sólo olvido de las fuerzas coercitivas y el de sí mismo frente al rescate de una forma superior de sensibilidad e, incluso, de sabiduría del mundo, que dirime su propia relación con la vida y la muerte? Para Rebeca la confesión de entrega de Juan, de alcanzarle "más y más cosas" sin cansarse, hasta las que hubiera ignorado que llevaba consigo o dentro de sí, se convertía “de golpe en una revelación (...) inaugurando una era vertiginosa en la que todo pareció cambiar de eje; el mundo, el alma, el tiempo" (99). El erotismo de La mujer desnuda es, en este sentido, marcadamente gótico, cuando va adentrándose cada vez más profundamente en un fondo que parece hacerse siempre más hondo (Lutz 87). En eso reside también lo trágico, en que el amor y su consumación lindan en peligrosa cercanía con la muerte, porque pisan ese "terreno prohibido (...) o mejor aún, el sagrado" de la desmesura en sí misma, ajenos a las normas, asociales (Bataille 37).

Es posible que la transformación de Rebeca, que empieza como un autoconocimiento, culmine en una revelación amorosa que determina su muerte. La separación anticipa esta especie de inmolación de los amantes, de no poder vivir el uno sin el otro antes del ataque furioso de los pobladores (Somers 100). Tras la muerte de Juan, Rebeca queda en estado de suspensión, los árboles se suman unos a otros creando "más silencio, más vacío, más confusión de situaciones vividas sin su tiempo" (Somers 116). Ella trata de distraerse en el camino, pero a su paso no cesan de manifestarse los signos de la pérdida. Resuenan en su mente, además, palabras inconexas como "Y sin poder explicarlo, sin poder explicarlo". Entra de nuevo en la zona hipnótica, febril, de los 
comienzos. Entonces dos árboles caen a su lado "de muerte súbita" remedando la muerte de los amantes y como respondiendo a esa explicación que ella no encuentra. Todas las imágenes remiten de una u otra forma a la muerte. Todavía más claro se puede ver con la aparición del caballo, cuya presencia ella percibe ahora como "el otro".

La imagen del animal se complica porque no construye un solo significado nuevo en sí, sino que fusiona los distintos sentidos que ha representado para ella: el asco, la enfermedad, el encarcelamiento y la liberación, el instinto. Demasiados ecos de sí misma que aparecen indiferenciados y duplicados a un mismo tiempo: "el caballo de la rastra, o su doble figura fantasmal o él mismo" (121). Rebeca distingue la "total indiferencia" de la mirada de animal y se consuela como diciéndose "pero al menos él sí está vivo", frase ambigua, porque no se sabe a quién excluye ¿a Juan, a sí misma? Tal vez lo único que quede vivo sea el caballo como instinto, y es por eso que Rebeca echa a correr tras él para alcanzarlo y sentir un "cuerpo de verdad" a diferencia de sus piernas, ahora "algodonosas" (122). En este punto la proyección del personaje en el animal toman un giro delicado, pues al sugerir la locura del caballo pareciera estar apuntando a la de sí misma producto de la persecución del pueblo: "lo han enloquecido allá, como bien puede enloquecer un animal al que de golpe se le adjudica un contacto maligno" (122).

La muerte de Rebeca resulta entonces ambigua. De un lado, su ahogamiento aparece como la única solución frente a una sociedad "anémica": vencida por las circunstancias y tomada por el "pesimismo", su entrega al río, aseguran los críticos, es "huida inconsciente del dolor y de la rutina" (Femenías 157; Montoro Martínez 227). Sin embargo, la imagen del cuerpo desnudo de Rebeca flotando en el río, de donde "sale una 
mano rígida que va diciendo adiós", en realidad reconecta con la idea de su naturaleza desconocida, aquella que al principio asociaba con él y que ahora en su inmersión reivindica. No hay, pues, pesimismo alguno, tanto menos cuando la novela en este punto significativamente dice que este final era el "definitivo intento de justificación" de la mujer (Somers 123). En el mundo sombrío de La mujer desnuda entendemos que esta justificación tiene que ver con una soberanía que Rebeca defiende hasta lo último y lealmente expía. De allí que el gesto de la mano sea una imagen de dolor y de alegría, también, algo como un guiño de vida o la prueba de su renovación en la muerte (Bataille 32). Ver el final como un acto amoroso coincide con esta línea de pensamiento y concentra verdadero sentido del exceso en la narrativa de Somers, que es fundamentalmente positivo porque no excluye la violencia y la muerte de la vida, y extrae de esa experiencia excesiva, del mal, el bien. ${ }^{25}$

La mujer desnuda admite un final abierto. La supremacía de la naturaleza psíquica de los acontecimientos por encima de la anécdota apunta a un tipo de relato que rechaza las coordinadas realistas a fin de mostrar una realidad interior. Esta intención coincide con la ficción gótica cuando se esmera en hacer presente lo aparentemente ausente, en "extraer luz de lo oscuro" (Lutz 82). La heroína se acerca al arquetipo del gótico femenino cuando su búsqueda está orientada al misterio de la existencia de sí (Lutz 84). Asimismo, el expresionismo gótico postmoderno se muestra como un mismo género dentro de la obra cuando la realidad se plantea en términos de "visión" o de sueño hipnótico, tal y como se postula en algunos dramas de Strindberg y en la percepción

\footnotetext{
${ }^{25}$ Olivero-Williams ve esta "entrega del cuerpo de Rebeca al río representa la literatura como objeto de fascinación amorosa” (47).
} 
gótica en general, donde "la realidad es un mal sueño, irracional, supernatural, hostil y extraño" (Leween 36).

La mujer desnuda, novela y personaje, evocan la idea de Somers de que "no inventamos lo inexplicable, [y] (...) el misterio nos asedia en mayor medida que en lo que logramos descifrar a fuerza de coraje" (Campodónico 229). El enigma persistente, el amor, que se plantea en términos de separación y ausencia, la ansiedad que generan los espacios domésticos, las escenas violentas de quienes se rebelan contra el lugar que les ha sido asignado, así como la descripción de un lugar remoto y extrañamente silencioso, de seres sin interacción entre sí, son rasgos góticos recurrentes en la novela. La incertidumbre que amenaza de continuo la subjetividad de Rebeca, los distintos nombres (imágenes) que adopta, y la violencia característica de sus impulsos remiten a la construcción inorgánica del personaje expresionista y a la necesidad de desmentir toda supuesta unidad individual fija. Por todos estos elementos presentes a lo largo de la narración, puede decirse que la novela tiene una marcada orientación expresionista, afín a la narrativa gótico postmoderna. 


\section{Capítulo 3. Subjetividad expresionista gótica postmoderna: "De miedo en miedo. Los manuscritos del río" (1965)}

De miedo en miedo. Los manuscritos del río (1965), segunda novela de Somers, aparece un año después de la publicación de Todos los cuentos (1953-1967) y es una de las pocas obras de la autora que no ha sido revisada individualmente por ningún crítico. Jorge Ruffinelli en su ensayo “Armonía Somers: paraíso infernal, celeste infierno", la atribuye a la primera fase de su narrativa tildándola de novela "singular", “poco lograda", de "fraseo extraño y no siempre eficaz" (272). Debido a la ambigüedad y a la estructura inestable que la novela despliega, es preciso argüir que la falta de sentido y/o de coherencia de las partes de la obra en su conjunto, a la que apunta Ruffinelli, no conduce exclusivamente a este punto de vista, y que, por tanto, ésta no necesariamente se categoriza en los términos pesimistas en que él concluye. Bien como novela corta de "transición" o parte del período de madurez narrativa de Somers, la complejidad estructural de De miedo en miedo desafía la capacidad interpretativa del lector y los métodos convencionales de aproximación a la obra literaria, lo cual adquiere sumo valor en el análisis de las orientaciones estéticas de Somers y la originalidad de su propuesta en el marco de la creación literaria.

Montaje y simultaneidad

Subtitulada significativamente "Los manuscritos del río", De miedo en miedo es una historia que combina el recuento de la vida de un personaje a la manera del relato picaresco, en una sucesión de episodios pasados, y la vida doméstica del mismo hombre que en la actualidad escribe sus memorias. La aparición del montaje y ciertos 
rasgos épicos paradigmáticos de la prosa expresionista se evidencia aquí por medio de lo que David William Foster llama acertadamente "el sistema de relaciones irónicas que establece el narrador entre lo que [él] parece ser y lo que realmente es”, tópico, asimismo, de la picaresca (9). El narrador-protagonista, un hombre en su temprana madurez, comienza evocando una aventura amorosa fallida a partir del encuentro con una mujer desconocida, con quien compartirá recuerdos, afectos y pensamientos del pasado hasta ese momento olvidados.

En principio la relación que entabla con la mujer sienta las bases de una situación narrativa realista, en tanto que ocurre en el marco de una relación posible. El lector se ajusta sin dificultad en posición de oyente, que gusta conocer los secretos del otro, y, más aún, se interesa en el intercambio que surge repentinamente entre los dos personajes, cuya misteriosa empatía aumenta el suspenso del relato. ${ }^{26}$ La sensación de realidad se ve reforzada, además, por lo que Miguel Gomes llamaría fórmulas paratácticas o reiteración de formas elocutivas, las cuales se emplean sistemáticamente, sobre todo al principio y al final de la historia, con el objeto de sugerir un orden en la construcción narrativa (564-5). Frases como: "Fue en ese instante crítico cuando", "y entonces fue cuando decidí", "Y fue así que", "Fue al llegar a ese recodo", "Entonces fue cuando lo inventé", "y entonces fue cuando surgió", "y fue de ese modo que", por mencionar algunos ejemplos, le confieren al texto una calidad de constitución coordinada. El lector se forja así la impresión de que estos recuerdos sueltos, de tiempo y espacio disímiles entre sí, obedecen a un orden

\footnotetext{
${ }^{26}$ El énfasis en el suspenso acerca esta historia al escenario del Female Gothic, el cual "tends to emphasize suspense rather than outright horror, (...) by limiting the reader's understanding of events to the protagonist's view" (Punter 279).
} 
común, y en virtud del tono fijo e inmutable que encierran las expresiones lingüísticas en pretérito, las percibe como certeras.

Ahora bien, este orden de realidad se ve alterado por la alternancia tiempoespacial entre el pasado y el presente, que interrumpen el flujo de los relato-recuerdos con situaciones inmediatas y viceversa, como si efectivamente sucedieran en un espacio-tiempo próximo entre sí. De esto nos da cuenta el diálogo entre el protagonista y la desconocida: "Disculpe — le solté de golpe— pero es que su pañuelito en el sobre plástico me ha hecho recordar ciertas épocas lejanas de mi vida”, a lo que la mujer replica: "No tan lejanas, por lo que veo" (Somers 13). El pasado también invade el presente o coexiste íntimamente con él: (en el automóvil) “Claro que sí - le dije sintiendo que todos los recuerdos del hotel me invadían de golpe, como de atrás del tiempo"; "Entré a mi casa completamente envuelto en aquella nube del pasado, en medio de la ingravidez de las cosas que se me escapan de las manos como a los cosmonautas" $(15,29)$.

Esta yuxtaposición de "escenas" o de historias que invaden a otras sin correlación apunta al efecto desestabilizador de la "épica" o montaje expresionista, cuyo objetivo es evadir una representación "orgánica” de la realidad en donde todas las partes del relato concuerdan en una unidad de sentido, para mostrar, en su lugar, las discontinuidades reales del mundo (Murphy 21, 16). El narrador-protagonista está consciente de esta estructura "inorgánica" de su relato cuando afirma: "uno no se echa en busca de pequeños fragmentos incapaces de recomponer el todo"; y también, más adelante, cuando confiesa: "la vida había sido un acontecimiento lineal, como una 
novela (...) divida en capítulos. Pero el río, siempre hambriento de mí, quería mis pedazos, fueran o no consecutivos" (Somers 18, 20).

Esta disposición de los hechos se corresponde con uno de los principios del montaje en la prosa expresionista cuando presenta lo que parece "un grupo de escenas inconexas que representan distintas fases por las que atraviesa el personaje en su camino hacia un estado vagamente definido de iluminación” (Murphy 21). Efectivamente, la trama, al alternar entre dos realidades, la pasada y la presente, provee un tercer espacio en el que el protagonista intuye que se está operando algo completamente desconocido y nuevo en él, tal como si estuviera en vías de descubrir alguna verdad. Y mientras "escribe” en su mente en un monólogo interior una de sus pasadas aventuras amorosas ilícitas, se intercala este breve pasaje, con visos de revelación: "Era un fenómeno extraño y primerizo, algo de lo que jamás hubiera podido responder anteriormente. Frené para esperar que dieran paso al camión, y el pensamiento que traía colocado sobre mi cabeza se quedó quieto" (Somers 27). La escritura de sus memorias, ya mental, ya concretamente en el papel, combinado con los diálogos que sostiene con la mujer desconocida, lo acompañan ciertamente en una especie de proceso que él mismo no sabe nombrar:

Y de pronto llegué a sentir hacia dentro de mí (...) que había acabado de nacer allí mismo algo que quizás no tuviera nada que ver con el mundo (...) ni siquiera conmigo (...) algo que me venía a entregarse en la forma de un campo interior completamente secreto. (41)

Hay, pues, una auto-reflexividad psicológica de la escritura y otra de corte metaliterario. La primera está asociada a la experiencia de este "algo" secreto. Este espacio nuevo que desplaza la realidad previa se corresponde con la búsqueda expresionista de 
estimular la apertura de un "heterocosmos discursivo", amén de propiciar en el individuo nuevos significados sobre la base de una visión del mundo profundamente personal (Murphy 57). Simultáneamente esta experiencia de lo desconocido concuerda con la del gótico-postmoderno de lo "irrepresentable" cuando se presenta de forma familiar e inaprensible y desligada de todo lo concerniente a este mundo, es decir, de la cultura afirmativa y convenciones dominantes.

La autorreflexividad se refleja en la escritura cuando el personaje elige deliberadamente la trama no-lineal. Esta, como se verá, asume el carácter ideológico expresionista en el empleo de la técnica del montaje y estilos discontinuos (el abstraccionismo, la interrupción, fragmentación del discurso), y subvierte orientaciones inveteradas de pensamiento que aprueban solo cierto tipo de realidad, desechando el resto de experiencias humanas que no encajan dentro de esa categoría (Murphy 15). El personaje ciertamente legitima el carácter fragmentario, automático y a ratos caótico de sus manuscritos, postulándolos como válidos a pesar de estar en oposición a las normas establecidas. Es el caso cuando dice que de pronto le "surgió la evocación entera, sin puntos y sin comas, tal como el pensamiento escribe sus memorias aunque los académicos se deshagan en señas desde sus sillones de guardia" (26). ${ }^{27} \mathrm{Y}$, más adelante, también, en relación con las formas "institucionales" del arte:

\footnotetext{
27 "Porque la verdad tal como está ocurriendo es esta: que ella entra al compartimiento tomada de los hombros por el marido que hasta la coloca en el asiento y yo escondido en el retrete del vagón esperando las etapas matemáticas como si fueran las de asalto a un banco o a una joyería, "eh, usted acabe de una vez o preste el turno" gritaban de tanto en tanto "sacos de m... aún no ha empezado a moverse el tren y ya desfondándose aunque esté prohibido hacerlo en las estaciones" era mi respuesta pero no podía gritársela como se lo estaban ganando porque si el hombre era capaz de reconocerme por el ojo que yo sacaba entreabriendo apenas la puerta al amainar los golpes estaba perdido hasta que se oyó el silbato y yo pensé respirando apenas el aire espeso quizás la ha besado ya y baja ahora del tren y viene lo de saludarse con el pañuelo gracias a que hay en este mundo tantas cosas así que aunque uno no pueda verlas desde cualquier situación de encierro sabe que se estarán produciendo del mismo modo y viene a sentir lo que sería estar
} 
El agente (...) me sorprendió hablando solo (...). Entonces yo decidí someterme a la ley común, ser el hombre que lleva el vehículo (...) en tanto el pensamiento sigue tironeando hacia lo suyo, como un perro (...) pero libre para orinar sobre las convenciones de una moral llena de reglas, de una gramática erizada de púas, esas que martirizan el cerebro de los que tienen que escribir... (52)

Las formas recurrentes de montaje y discontinuidad del texto proveen así un artificio que permite expresar, aunque sea momentáneamente, una realidad marginal que de otra forma no tendría cabida en el espectro de experiencias humanas posibles. Y en esto coinciden la postura ideológica del expresionismo con la necesidad del gótico postmoderno, en que al trazar una serie de escenas que no guardan relación entre sí con respecto a un conflicto central plantea la idea de que toda apariencia de un mundo armonioso es ilusoria — lo mismo que la linealidad del tiempo, la concreción de espacio y cualquier punto de referencia-. En este sentido, la ironía que el narrador escoge como medio para establecer las relaciones entre lo que él es y lo que parece ser manifiesta un estadio de conocimiento incipiente de sí, pero que da cuenta de la inseguridad del personaje y de la incongruencia que empieza a percibir en el mundo y en sí mismo.

\section{Ansiedad narrativa}

El concepto expresionista es "paradójico y de naturaleza compleja (...) [trata] lo que el hombre es superficialmente y lo que es agónicamente en las profundidades de su alma" (Foster 9). Citamos la frase de William Foster a propósito de la realidad aparato mezclador que lleva funcionando ahí me engulliría en dirección a su estómago hormiguero..."

(Somers 26-7). 
profunda que apunta el personaje de De miedo en miedo en relación con su vida:

"Puesto que la verdad sobre sí mismo con que uno quede al estar solo se tratará casi siempre de otra cosa"; "empecé a revivir una agonía en varios tiempos que la memoria me tenía guardada sin rendirme cuentas (...) que yo tuviera siempre un miedo loco de morir" (Somers 10, 16). La asociación de miedo y muerte es significativa en el relato porque concentra la naturaleza de la historia que se titula así, "de miedo en miedo", con lo cual admite que las memorias tratan de un tipo de experiencia profundamente personal que linda con la escisión del sujeto, la pérdida del "objeto" o pérdida de sí. ${ }^{28}$ Este sentimiento de pérdida se muestra en el personaje por medio de confesiones en las que privan la sensación de una existencia y de un bregar inútiles: "el baile sin porvenir en que me había embarcado"; "yo malamente escondido, como buscando amparo de la lluvia bajo un árbol sin hojas"; "yo (...) empecé a descender en la oscuridad, un pasaje de puertas angostas y escaleras que están siempre dándonos en la nariz con una pared ciega. Y todavía hasta hoy (...)" (Somers 8, 17).

En efecto, cada recuerdo que evoca el protagonista retoma una situación en la que él juega un rol distinto, no obstante, la idea de no-ser y de no-identificación con ninguno de los roles prevalece. El tinte picaresco de la novela yace justamente en que el personaje recorre estos distintos mundos en los que las convenciones de tiempo y espacio, materia y espíritu, realidad y ficción son irrelevantes para los efectos de la historia (la novela), así como tampoco aportan ningún significado a su vida actual. En

\footnotetext{
${ }^{28}$ Existe, en efecto, la muerte real, pero hay también una muerte segunda o "simbólica" basada en la pérdida de valor del sujeto (Beville 95). Según Julia Kristeva, el miedo que subyace en la angustia consciente de la muerte "se eclipsa frente al miedo a perder el objeto o a perderse como objeto" (28). Esta experiencia se asocia con la muerte simbólica que actúa como eje central en la narrativa góticapostmoderna (Beville, Gothic-postmodernism 94).
} 
cambio, pareciera que están allí, como afirma Fred Botting, para sugerir "que el mundo es ficcional en sentido general, un efecto de narrativas, identificaciones, fantasías y deseos que ya no rinden homenaje a las grandes narrativas dominadas por el principio de realidad" (Gothic 170). La duda epistemológica que embarga al protagonista a lo largo de la obra obedece a esta falta de centro, de sentido unificador de la realidad:

cuál será el eje que lo sostenga todo (...) En qué idea, en qué cosa poder hallar una justificación para este absurdo chapaleo (...) El chapaleo sobre esta ciénaga llamada vida, tan buena como trampa, en la que no se corre ni el peligro de irse para debajo de una vez ni la esperanza de flotar arriba. (Somers 41)

El estado de estancamiento que refiere aquí se traduce, asimismo, en el sinsentido de la vida: “¿desde mis tranvías para acá, tiene o no tiene sentido todo eso que a uno le ocurre, ir de cosa en cosa, de gente en gente, de nada en nada? (51). El vacío al que apunta no se debe a una carencia - hay experiencias, gente, imágenes-, sino, más bien, a un exceso inconmensurable de ellas: "No había descanso. Las cosas y sus depositarios continuaban atiborrándonos a través del sueño. Uno no era capaz de romper el nexo, de sobrenadar en un completo vacío ni cuando lograba dormirse a duras penas" (48). Es significativo, sin embargo, que al vacío le suceda una imaginería de muerte que ya no paraliza sino que lo hace fabular sobre sí mismo: mejor entonces pasar de largo (...) y pensar en algo triste por ejemplo engancharse unos minutos a ese séquito muy bien el que va adelante sea yo y al mismo tiempo me acompaño en mi coche con un amigo al lado mío y él no sabe que vamos a mi entierro que yo soy el otro (...). (53)

El vacío se torna enriquecedor en tanto que su percepción despierta una capacidad imaginal autorreflexiva en el personaje, que empieza a vislumbrarse uno distinto al 
mecánico uno-tras-otro que ha sido hoy. Esta conciencia de sí, aunque incipiente, se observa ya en su preferencia por la tristeza en lugar de la nada, un tópico que podría considerarse modernista, recurrente en la narrativa de Faulkner. Y no obstante, la actitud del personaje asume un marcado carácter postmoderno cuando se enajena de la comunidad y de sí mismo, puesto que no solo el amigo no sabe que él está muerto sino que él mismo dice ser "otro" del que es, que está muerto (Beville, Gothicpostmodernism 46). ${ }^{29}$ El hecho de recrear ficcionalmente su muerte concuerda con la necesidad postmoderna y gótica de narrar esas experiencias que cuestionan la existencia y los conceptos de realidad (46). ${ }^{30}$ De esta ambigüedad surge la llamada "ansiedad narrativa" en el sujeto: una necesidad urgente de articular el estado de ambivalencia y duplicidad en que yace sin remedio, y que, en este caso, aparece como una muerte en vida, muerte simbólica y real (Botting, Gothic 170).

La nostalgia y la fabulación o la combinación de ambas son producto de esta ansiedad. La mezcla de diálogos y monólogos, de soluciones ficticias de lo pasado en el presente sirven de medio expresivo para evocar emociones y deseos ocultos.

Curiosamente esto se hace más evidente en la atmósfera doméstica, donde la escritura surge como una necesidad de subsistencia primaria: "Esa noche, oyendo llorar al niño, y atosigado no sabía por qué, decidí levantarme y escribir algo. Algo tan elemental, pensé, como bañarse a causa de los piojos o la arena que le andan a uno por fuera,

\footnotetext{
${ }^{29}$ Anteriormente ya había hecho el personaje alusión a una experiencia similar: "Me quedé unos minutos fuera de mí, como si me hubiese subdividido en dos hombres" (35).

${ }^{30}$ El protagonista recrea de continuo su muerte: “- $-(\ldots)$ Yo no te entiendo a veces [le dice la mujer desconocida al protagonista]. Si el pensamiento de la muerte ha sido siempre tu verdugo. - Pero no la muerte que yo me acabo de inventar - le expliqué-. Morir es un destierro ¿no? Entonces yo lo elegiría así: Una estrella con luz azul, unas cascadas también azules, transparentes y detenidas, más bien como elementos ornamentales, para que ni el ruido del agua las molestase. $\mathrm{Y}$ un silencio acompasado cayendo en gotas sordas desde la música..." (Somers 74).
} 
siendo que en realidad molestan hacia adentro" (Somers 18). Primero, la banalidad con que se compara el ejercicio de escritura deconstruye toda idea de solemnidad o jerarquía asociada al oficio. Luego, simultáneamente, la idea del género femenino como blanco de ataque en los espacios domésticos se revierte. Una inversión del paradigma del gótico femenino se opera en el texto cuando es el protagonista de la historia quien se siente preso en la casa y en peligro de muerte, en lugar de ser el típico transgresor. ${ }^{31}$ Allí, como en el gótico femenino, el personaje sufre la condición de estar preso, con lo cual revierte el género y las expectativas del Female y del Male gothic (Leeuwen 42). En cambio, la esposa es su "celador", una garganta aterradora "de las que sale una voz de lavabo viejo cuando se engulle el agua", una "mujer desconocida con que uno se casó" (Somers 71, 54, 73).

Ser marido y detestar la casa, las obligaciones, su propia esposa es exactamente la inversión de los roles opresivos del matrimonio dentro de la narrativa del gótico femenino (Leeuwen 40). Así, la casa era un lugar "sin solución donde alguien se habría olvidado de que el actor estaba jugando su propia muerte" (Somers 61). La cabeza de su mujer estaba llena de "Heladera, televisor, los doce niños con que era capaz de embarazarse si yo no empezaba a administrarme. (...) ¡Cosas, cosas y más cosas (...) consúmanse antes de llegar a mi vida!” (48). La mudanza del apartamento al nuevo chalet era "Simplemente una casa nueva para trasplantar la misma vida", "otro pretexto para postergar un poco más algún capítulo, esos de cortar el hilo, quitar un trozo del ser inconfesable y añadir lo que siga" $(52,54)$.

\footnotetext{
${ }^{31}$ Llama la atención que el personaje experimente ansiedad en el espacio que corresponde al hogar, lugar en que el personaje femenino suele ser el acosado y perseguido por excelencia. Según David Punter, para la heroína del Female Gothic, "the domestic ideology (...) throughout the narrative, is suggested to be the cause of all her problems and suffering" (281). Aquí, sin embargo el marido es el afligido.
} 
Una alteración similar ocurre con el rol del hijo, a quien no siente como suyo. ${ }^{32}$ A diferencia de las historias del gótico moderno, donde el niño es el perseguido o la víctima, aquí en cambio es una "criatura" perversa que mantenía embrujada a la madre, que: "la tenía como agarrada en su pasión oscura, en su siniestro monopolio de sonrisas del que los demás participábamos desde afuera" (29). Madre e hijo se confunden en una misma estampa de calidad metálica, cuya nota común es la dureza y la impersonalidad: "Ella y el niño refulgían como monedas recién acuñadas". Más adelante, ambos aparecen a su vista como un monstruo bicéfalo: "Entonces yo empecé a temblar ante aquella figura de dos cabezas con el mismo color de pelo, el mismo espejo de alma" $(62,60)$. Este efecto de alteridad que producen la imagen de la mujer y del hijo, resultado de la impresión negativa del personaje, son, sin embargo, reflejo de una alteridad oculta en él. Se trata del mismo distanciamiento que anteriormente se operara con respecto a sí mismo — su desdoblamiento al verse como muerto y vivo a la vez- que ahora se impone ante la visión de sus seres queridos, ajenos a él. La alteridad del personaje se hace más explícita cuando, al tiempo que experimenta rechazo y extrañamiento hacia ellos, tiene, asimismo, miedo de perderlos. ${ }^{33}$

Efectivamente, el desconcierto que produce esta ambigüedad se incrementa cuando esas imágenes monstruosas no provienen de un ámbito externo, sino de su territorio más íntimo, su hogar. El miedo funciona entonces como un terreno liminal entre la razón y el sinsentido, como un tercer espacio ambivalente, paralizador y

\footnotetext{
32 "Ya pasada la hora, encontré a mi mujer en la acera de nuestra casa, abrazada a su niño" (54).

33 "Ella era bien capaz de hacerlo de verdad, tomar un día al niño, irse sin decirme adónde. Vislumbré por algunos segundos lo que acababa de desear concedido así, sin necesidad de llaves, de escapatorias subterráneas. Pero el miedo hacia una realidad que pudiera ocurrir era más grande que mi valor para recibirla de igual a igual, me golpeaba en la cara con sus aguas revueltas dejándome ciego" (60).
} 
estimulante a la vez, que da cabida a la metamorfosis, pero también al laberinto y al nacimiento de monstruos (Beville, Gothic-postmodernism 96).

Monstruos, dobles

Todos los textos góticos, independientemente del hecho de que traten, guardan relación con lo monstruoso, pues operan en ese espacio que media entre el ser y el otro (Beville, Gothic-postmodernism 40-1). Los fantasmas y los monstruos o, para usar el término que mejor se aviene a ellos, los "grotescos", se empleaban intencionalmente en el gótico para encarnar las contradicciones y ambigüedades del ser: esos obstáculos que se anteponen a la sabiduría subjetiva y a la creación de una identidad coherente (Kristeva 39). Algunas de esas contradicciones obedecen a ese espacio que media entre la vida y la muerte o entre la realidad y la ficción (39). Cuando el protagonista conoce a la mujer en su trabajo, el diálogo con la mujer le resulta al lector completamente creíble: una clienta pregunta por un libro, el hombre que la atiende se siente profundamente atraído por ella, luego la sigue, conversan, se despiden. Más tarde el protagonista coloca el episodio en un pasado distante, cual si todo el diálogo y el encuentro que se produce entre ellos corresponde a una ficción, una fabulación más de su pensamiento:

Fue al llegar a ese recodo mental que, por obra de algún resorte mal controlado saltándome a la cabeza, vine a saber que la desconocida, a pesar de haberlo provocado todo con su forma de andar devolviéndome marcha atrás, no existía. (...) No recordaba más que su voz asordinada, el temperamento de su risa, el sobre del pañuelo. (Somers 17) 
Desde el comienzo, los signos de una relación ilusoria empiezan a manifestarse y la verosimilitud de la existencia de la mujer se pone en duda ante lo que parece una invención del protagonista, una ilusión que se ajusta a su apetito de viejas historias. ${ }^{34}$ Otros signos también contribuyen a crear sospecha en el lector. Por ejemplo, la confianza inmediata que el personaje le confiere a la extraña como si fuera una amiga de siempre. ${ }^{35}$ Más tarde, los detalles sobre sus fobias (el asco de tocar manillas, puertas, vasos públicos), todas confesiones de las que él mismo admite sentir "un poco de vergüenza”, se perfilan luego como un diálogo sujeto a su exclusivo capricho: “—Y los bultos que tenía que transportar-agregué como si sólo lo mío debiese contar en adelante - eran también una obsesión a causa de su posibilidad de intermediarios" (Somers 15).

Tal y como ocurre en los romances góticos, aquí la realidad y la ficción no están claramente separadas sino que ambas se entremezclan "tortuosamente en esta distorsión auto-consciente que parece seria y ridícula a la vez" (Botting, Gothic 108). Al mismo tiempo, la ambivalencia se acentúa cuando referencias realistas, como las breves descripciones de su llegada a la librería, de sus despedidas o de sus encuentros, dan la impresión de que se trata de dos seres individuales. ${ }^{36}$ Ella es su confidente en

\footnotetext{
34 "cierta dulce apetencia de infancia insatisfecha de relatos, que se inclinaba sobre los verbos en pasado" (Somers 34).

35 "Le conté entonces con una sobrecarga de detalles que jamás había usado con nadie para reconstruir episodios una de las pasiones de mis siete años, el amor por aquellos pequeños monstruos" (22).

36 "Ella volvió días después por otro libro. Acababan de hacer una pequeña limpieza. La vi husmear al aire" (20). "Tenga — le dije a la mujer al día siguiente mientras nos sentábamos a inaugurar nuestro primer desayuno juntos - " (29-30). "Pensé, de pronto, en la poca gasolina que me quedaba, lo justo para tirar a mi casa. Si daba en preguntarme el recorrido que iba a hacer y con eso aproximarla a algún lugar me moriría de humillaciones allí mismo. Pero no sucedió. (...) la veía alejarse empequeñecida por el espejo [retrovisor mientras] (...) maniobraba como a fórceps para salir de mi sitio" (16). "Esta vez había sido previsor (...) y me di el lujo burgués de ofrecerle el asiento. Pero ella rehusó con cierto misterio" (24).
} 
medio de todos los seres extraños extraños que le rodean, personajes planos que comparten el mismo destino absurdo y sin sentido que él, pero que a diferencia de él y de ella desconocen esta verdad. ${ }^{37} \mathrm{Y}$, no obstante, su relación con los otros no está exenta de fantasía. El lector se percata de que no sólo la de la desconocida sino todas sus interacciones se dan en un marco profundamente subjetivo, teñidas de la mitología y de la atmósfera íntima del protagonista:

Un individuo con olor a hoja seca y cara de pájaro de colección abrió el día. Yo le alcancé el pedido en actitud de sometimiento. Pero mientras él buscaba algo en el pie de imprenta con su uña dura, le pregunté girando hacia mi lado crítico: “¿Y usted, es pájaro u hombre?” En aquel entendimiento por encima de lo normal, él pareció asomarse al borde de un arroyito que pasaría por allí antes de que levantasen el edificio y descubrirse con asombro. (...) —Eh, usted ¿no me ha oído que acabo de pedirle un Linneo? - gritó de pronto como exhibiendo el linaje. (...) Miré hacia el viejo que había percibido algo desde allá arriba a causa de la voz un tanto airada del cliente. "Un día te pegaré a ti también, mascullé mientras encaminaba a mi volátil hacia sus documentos. Espera hasta que una noche cualquiera se apague la luz en la barraca". (Somers 32-3)

El diálogo que sostiene con el hombre-pájaro aparece tras la respuesta del cliente como una mera fabulación; lo mismo que la amenaza que profiere al jefe, a quien trata significativamente de "tú" en un tono marcadamente despectivo. Nos encontramos ante personajes que funcionan entonces como caracteres distintivos y, paralelamente, como dobles de él mismo, en tanto que son figuras que el protagonista modela bajo una mirada deformadora, siguiendo la línea "inorgánica" expresionista. La transformación del cliente da cuenta de ello, pues se le animaliza y se le transporta a un tiempo anterior

\footnotetext{
${ }^{37}$ El protagonista afirma la insignificancia de estos seres cuando aduce: “—Los conozco — dije con ensañamiento - a todos estos ejemplares que no parecen ni existir, porque me he dedicado a imaginarlos en su vida secreta desde el momento en que desaparecen de la vista. Llega la noche y lloran, y mientras lloran gozan, y en tanto gozan se levantan y luego vuelven a caer para empezar de nuevo. Hasta que un día el sexo se les pudre - añadí cada vez más dueño de mi iniquidad - y no por enfermar, sino como las frutas antes de secarse" (Somers 82). "Le contaría a ella el episodio, repasándolo antes mentalmente de acuerdo con el nuevo sistema" (33).
} 
a la urbanización, disociando la imagen del cliente humano y común a favor de una imagen primitiva e inusual. La caracterización inorgánica de los personajes se observa asimismo cuando el narrador problematiza conscientemente las fronteras de la norma, al decir que el hombre-pájaro está "por encima de lo normal” y como asomándose a un tiempo más allá del ordinario. A este carácter marginal y extraordinario que se le atribuye al hombre —aspecto expresionista — se le añade un cariz gótico en la vaguedad de la referencia temporal-espacial. Como si todo esto no fuera suficiente, la ambivalencia de la naturaleza de los personajes del relato resulta excesiva cuando el personaje principal articula la pregunta de si se trata de un pájaro o de un hombre, pues pone en duda el pensamiento orientado según dicotomías convencionales — la distinción animal-hombre - revelando la manera en que "el otro está construido y posicionado tanto como alien como ser inferior" (Punter 264).

\section{Metalepsis}

Pero el efecto de desconcierto producto de la alteridad no se desprende solo de los personajes; lo monstruoso no se sitúa únicamente en quienes rodean al protagonista sino que se extiende hacia el lector al referirse directamente a él, tratándolo alternativamente de "usted" y de "tú", con mayor frecuencia. ${ }^{38}$ Aún cuando el texto eventualmente aclara la persona a quien va dirigida la pregunta "Y usted ¿es pájaro u hombre?", el lector se ve interpelado por el relato desde "la perspectiva del monstruo en

\footnotetext{
38 "The second person is par excellence the sign of relation. Even more strongly than the first person, it announces the presence of a communicative circuit linking addressor and addressee. (...) Every reader is potentially you, the addressee of the novelistic discourse" (McHale 223).
} 
incómoda intimidad" (Punter 266). ${ }^{39}$ Por lo demás, al situar la fuente del horror

alternativamente en el lector, en el cliente y en el jefe, esto es, fuera de su

individualidad, el personaje y la novela apuntan a un tipo de relación con el monstruo

específicamente gótico-postmoderna, en tanto que no hay un destinatario concreto y el

lector culmina, en consecuencia, sintiendo la misma desorientación de que es presa el

personaje (Punter 266).

El uso del "tú" contribuye decididamente a este efecto. La segunda persona

referida en los monólogos del protagonista se comporta como una forma inclusiva o

metaléptica que desdibuja los límites entre el mundo real del lector y el de ficción,

sembrando de continuo la incertidumbre en éste, para quien resulta inevitable verse

incluido en la situación discursiva. Esta confusión se incrementa en el lector a lo largo

del texto por medio de la iteración, quien entonces se ve obligado a participar

vicariamente de una multiplicidad de situaciones en casos amenazantes, otras

incómodamente perturbadoras. ${ }^{40}$ Distintas llamadas falsas al lector, como el episodio

en que el protagonista emula el diálogo entre él y el cura, causan un efecto similar.

\footnotetext{
${ }^{39}$ Una impresión similar señala Ángel Rama en los textos de Somers, cuando dice que estos colocan "el golpe bajo" "con violencia ante nuestros ojos, [y] nos obliga a comprobar que existen, los refriega contra nosotros para tratar de contaminarnos - que nadie quede ausente de este horror real- y conducirnos de ese modo al desasosiego de un mundo inseguro rompiendo nuestros trillos habituales". Ver "La fascinación del horror", Marcha, pág. 30.

${ }^{40}$ Según McHale, las relaciones agresivas en el marco de las representaciones postmodernas funcionan, asimismo, como modelos de relación entre el texto y el lector: "here the metaleptic relation with the reader is mirrored by the text content" (226). "(Pero yo voy a demostrarte cómo se puede vencer a un pequeño fardo que huele a todo cuando su madre entra en la cama, pensé, y en cuanto a ti, enamorado de mi persona sólo al funcionar el motor del coche, ya te cobraré ese ruidito que te vuelve loco en alguna forma)" (Somers 29). "pensar en el morir es el mejor castigo para ti y debe ser por eso que los que te olvidaron van a su entierro cada día pero tú debes comprender que yo no hubiese podido llegar así contigo a casa con el recuerdo de las cuatro manos bajo el agua" (54). "Entonces fue cuando enfilé el amor hacia tu pequeña hermana (...) solo voy a nombrarte a ti con el que en forma tan perversa te aludía. Mi pobre, mi querido Sapo, qué fiel me eras. (...) Pero ahora, antes de morir, porque siempre se puede uno estar al borde de eso, quisiera contarte lo otro (...) Eso mismo: tu hermanita me hacía oscilar la vida allí como un péndulo" (92).
} 
Adoptando el formato del texto dramático, se señala un diálogo entre ambos que, en lugar de colocar en el apartado el nombre del cura, coloca "Usted". Si bien el lector sabe que el texto se enmarca en una suerte de carta que el protagonista escribe al amigo, la segunda persona formal se percibe como un tercer personaje diferente del que es:

Lugar, el comedor de la beata. Personas: usted, yo, ella de tanto en tanto. Usted, mirándome las manos que he puesto sobre el mantel: - Son, creo, las más hermosas manos que haya visto. (...) - Dicen que las heredé de mi padre, junto con esta depresión en la barbilla. (...). (La mujer, apareciéndose con la fuente de su invariable cena de cura que se cuidaba mucho, patatas hervidas y jamón crudo, esto último lo único que le se le podía comer al animal sin correr el riesgo de ponernos demasiado tiernos, según lo había dicho usted otra vez).

Usted: - Tu padre, bien que lo recuerdo, hijo del abogado que quiso un militar en la familia. En cambio, por el lado de tu madre fueron campesinos, al menos hasta donde consta en los asientos bautismales. (La arpía desencantada abandonando el cuarto).

Usted: - Pero el óvalo de tus uñas saltó sobre la mansera de los arados... (Somers 47)

La variedad de usos de la segunda persona produce así lo que McHale llama un "tú" flotante en la novela, en la que la equivocación del destinatario se mantiene viva y patente hasta el final de la historia, colocando al lector en las distintas situaciones discursivas sucesivamente, amén de la ambigüedad de la llamada (225). Esta relación metaléptica o violación de las fronteras ontológicas entre el protagonista y el otro, el protagonista y nosotros, se explota aún con mayor fuerza en la relación amorosa con la desconocida.

El amor cumple entre sus muchas funciones, de forma más o menos indirecta, la de sentar las bases de las relaciones en distintos niveles ontológicos dentro del relato, bien por medio de la actitud consciente del personaje, de estar moviéndose entre 
distintas existencias, o bien por vía de lo fantástico, haciendo indefinibles los límites entre los distintos mundos (McHale 223). En la relación amorosa con la mujer pueden reconocerse ambas variantes. Primero, la desconocida encarna un interlocutor misterioso e ideal, sin pasado, futuro ni presente, con quien él sostiene un diálogo íntimo. Muy pronto, el tono personal de esta relación de diálogo afantasmado, que "era como una caricia solitaria con la imagen del otro ser bailoteando en el vacío" nos lleva a concluir que la mujer, más que "su vicio secreto, una especie de droga", es verdaderamente solo una "sombra" con la que él "compone sus novelas" (Somers 34, 66). En otras palabras, la mujer es un doble de él, pero de una variación de él o de algo que él ha perdido. En particular hacia el final, de simple oyente, el personaje femenino pasa a ser la voz de la conciencia ${ }^{41}$ y aunque constituye su piedra de tranca, al mismo tiempo lo distancia de la realidad y le da sobre ella una perspectiva especial. ${ }^{42}$ Esto se refleja en el incremento de juicios valorativos de sí mismo que definen más concretamente su enajenación, apuntando a una toma de conciencia. ${ }^{43}$

La desconocida, puede decirse, es ese objeto perdido que el protagonista instala dentro de sí: ${ }^{44}$ una recuperación de la memoria de cara a un presente cuya legitimidad caduca reclama sentido. ${ }^{45}$ De ahí que su relación sea ambivalente, que de un lado se

\footnotetext{
41 "[L]o tuyo es con dolor, los amas desde el odio. Y si no fuera así no los tendrías tan adentro" (83). "tú eres como un topo", "es que tú buscas un chalet para convivir cuando lo que necesitas sería un faro para vivir solo" (65), "por lo que saco en conclusión un matrimonio defensivo" (56).

42 "Mi costumbre de mostrarle las entrañas y su desesperación por revolverlas y encontrar símbolos, nos empezó a fanatizar, a impedir el curso hacia la vida" (Somers 34).

${ }^{43}$ Así, se refiere a sí mismo "como un poseído" (72); "como un ladrón escondido entre las sombras" (79); "dueño de mi iniquidad" (82); "como un robot", "vencido" (84); "como el autómata que era" (86); "un gusano enfermo" (87).

44 “[S]iguiendo el mismo juego, le daba a alguien otra versión de mi pavor, momificado desde la adolescencia en su sepulcro más suntuoso" (30).

${ }^{45}$ El protagonista asegura que ella ha "desatado" "la corriente hacia atrás", lanzándose a una revisión del
} 
identifique con los aspectos benéficos de su pérdida y del otro, con los aspectos maléficos de ella. Los recuerdos abominable de abortos sangrientos, de golpizas, traiciones, crueldades pasadas tienen sentido en la medida que estas "visiones apocalípticas son inspiradas por el deseo de imponer un orden al tiempo y, de este modo, dominar el futuro y hacerle menos amenazador, por menos desconocido" (Zamora 171). ${ }^{46}$ La explicación "histórica" de su pasado o narración retrospectiva a la mujer trae consigo si no una comprensión, sí una consolación psicológica fundamental para seguir vivo. ${ }^{47}$

Según Julia Kristeva, la identificación paulatina del sujeto con el objeto, en este caso del protagonista con la mujer, es el primer paso "de un desdoblamiento de su yo, ante el inicio de una serie de identificaciones contradictorias que el trabajo de lo imaginario intenta conciliar” (140). En esta conciliación empiezan a aparecer los rasgos fantásticos de la relación entre ambos, una vez que el protagonista, consciente de que ella es una voz que está dentro de él, puede acceder a ella en cualquier situación, incluso en las más improbables. ${ }^{48}$ La confusión con su doble se intensifica

pasado que empieza por su infancia para ir a dar con el recuerdo de su matrimonio y su infelicidad actual (34): "la memoria de aquel día en que se debió decir no y salir a todo correr ante las bocas abiertas del clan casamentero", "el amor lo merecería todo... pero si nos cayera en suerte si no fuera siempre de otro como los cuadros de las exposiciones o los pisos horizontales que siempre el que nos gusta más es el que tiene el letrero de adquirido..." (79).

46 "Tú y tus pequeñas cosas son como mis vacaciones. Hablo contigo y duro unos días más. Es esa la verdad. Porque yo era como un ciego que oía ruidos, y ahora van saliendo formas" (66).

47 "Yo quería, a pesar de todo, seguir estando vivo", el protagonista en las últimas páginas (Somers 87).

48 "Mi mujer empezó entonces a hablar, y yo a utilizar su música para continuar en lo mío como unos minutos antes, feliz de aquella ruptura en la que el pensamiento se hacía su carrera sobre las vallas, lanzándome a sintaxis liberadoras. ...Y así fue para cortar tantas cosas como estoy ahora casado y debiéndote aún el capítulo negro de mi amante histérica y suicida que se me tiraba en las vías de los trenes (...). Y todo esto hasta que, hinchado con el aire de mi monólogo interior y mientras lo expelía, (...) Dieron entonces ellas en interferir como dos opuestos" (Somers 55-6). A partir de aquí él admite conscientemente que ella es su invención, un colaborador dentro de su monólogo personal y que él lo escoge así, deliberadamente. 
cuando la mujer de hecho aparece de forma extraordinaria en el automóvil entre él y

su esposa camino al chalet, momento en que ambas voces se perciben ya como una

sola:

comencé a sentir como si la sombra de aquélla cuya mano había visto por momentos antes por el espejo [retrovisor] se hubiese desprendido de su cuerpo para meterse entre mi mujer y yo en camino hacia al chalet que veríamos esa tarde. (...) Y metidos en la maraña los temas de la otra, cuyo estilo me conocía al punto de que mi lengua se enredase con la suya.

(Somers 56)

Los límites entre los personajes se tornan irreconocibles cuando ella no sólo es su "otro" sino que también es la "otra" de la esposa, en tanto adversario de "la mujer real" (61).

Es evidente que aquí ya los aspectos "maléficos” o negativos de él se proyectan en la mujer, cuyo comentario en realidad oculta un malestar del marido. De esta confusión de voces $^{50}$ resulta no obstante una toma conciencia que discierne entre el miedo paralizante y el miedo como aliciente de vida, un poco lo que la mujer representa para él:

-Solo que tus preocupaciones van a los pequeños miedos - dijo ella al final de mi sensación como si la hubiese visto hacer el recorrido- cuando quizás se trate de otras cosas (...) Quién sabe si las zozobras de una pobre vida que viene siendo convidada a dar su salto... (90)

El exceso de imágenes que carecían de sentido y que se anclaban en un miedo de inhibición pierden ahora la magnitud con que venían cargadas, y se muestran entonces como lo que son: "pequeños" temores que encubren otras emociones más urgentes. Por

\footnotetext{
${ }^{49}$ Hasta ahora la mujer aparecía como un individuo, una persona distinta de la esposa, con quien él conversaba y se escudriñaba: "Y ahora — dije al día siguiente a la otra mujer, como si mi intento de traición no hubiera existido - necesito saber por qué hice algo cierta vez, algo peor que lo del anillo" (36). Ahora aparece como una voz en él: "—iEs que has incluido algún licor en la compra para la cena con nuestros amigos? - preguntó de pronto mi mujer siempre en lo suyo. —Dile que sí, que no interrumpa, y que ese niño que trae, aunque no dudaría jamás de tu paternidad, no se te parece, completa el caso hasta burlar la trampa de la herencia" [replica la mujer desconocida] (57). Más adelante el protagonista aduce, en relación con la desconocida: "tuve cierto miedo de que mi encuentro con su doble [la esposa] le hubiera sido transmitido de algún modo sobrenatural y que su forma de mirarme ocultase el fenómeno" (65).

50 "Éramos como dos cuerpos bajo una misma piel”, "-Es que yo no soy sino tú- le dije de pronto con asombro" (88).
} 
eso, si al principio ella desata la memoria "hacia atrás" a manera de evasión, ese mismo espacio de "sintaxis liberadoras" lo convida a la inmediatez del presente, en el sentido de que resalta el paso del tiempo, la existencia del día a día y, con ello, la conciencia de la mortalidad. ${ }^{51}$

Los dobles y monstruos del protagonista despliegan los límites de las posibilidades del sí mismo a través del exceso, pero uno que él experimenta significativamente como un "castigo", es decir, como una conciencia de culpa que lo confronta a lo que está por debajo del miedo: "Era como recibir un castigo por haberme ido despojando día tras día tan a la última verdad, de una en otra envoltura, hasta quedar sin nada adentro" (90). Si la memoria engendra monstruos, tales como la mujer en la fantasía del protagonista, con todos los "tú" reprochadores del relato, ella misma es portavoz, entonces, del vacío concomitante de cada quien, del amor que echan en falta o que nunca es completo. Por eso cuando el protagonista se debate entre un extremo y otro, entre el amor ideal (la mujer inaccesible) y la falta de amor, la mujer le avisa sobre los límites, reivindicando el amor imperfecto allí donde él pone la nada. ${ }^{52}$

Lo monstruoso se desarticula en virtud de mostrar el lado humano que preserva, siguiendo la línea del gótico postmoderno, que amista al lector con la perspectiva irracional poniendo de relieve lo positivo en el odio y los prejuicios desnudos, o el efecto benéfico que lo monstruoso puede promover en sí (Punter 265). La mujer puede

\footnotetext{
${ }^{51}$ La mujer ya le había advertido de la imposibilidad de mantener este diálogo sin fin sobre el pasado: "creo que no podrías entregármelo todo por completo (...) eso molestaría los negocios del presente, siempre abrazados al calendario" (Somers 34). Más adelante, también le señala el valor del tiempo: "Mira ese gato, lo vive todo mejor desde abajo. (...) está sintiendo el tiempo de la casa" (71).

52 "Imaginé la vida así, completamente deshabitada del amor, cuando ya ni sombra ilusoria bajase a consolarme", a lo que la mujer le replica: "Que cada uno tenga lo que le toque en el reparto, siempre que sea su ración de amor. Todo menos estar vacíos" (87).
} 
resultar inexistente, pero su amor por ella es real. ${ }^{53}$ La necesidad de presentar monstruos y fantasmas, como apunta Beville, no es la de mostrar simplemente formas abyectas, sino la de sacar a relucir realidades que requieren ser reconocidas y comprendidas como manifestaciones de deseos negativos, que si bien no tienen cabida en el orden de las filosofías esencialistas que rigen el ámbito vital — democrático, autónomo y progresista-, existen en el ser humano y perfilan su humanidad también (Gothicpostmodernism 97).

\section{Senex y puer}

Uno de los factores desestabilizadores de la caracterización del protagonista yace en su sentido de desconexión en relación con los hechos en los que él participa y de los cuales es responsable, pero ante los que aparece siempre asombrado por el horror que representan en realidad. ${ }^{54}$ Como en los personajes góticos, el responsable de las fantasías más violentas, "tiene que ser otro", alguien ajeno, distante, alguien que sólo podría aparecer como un desconocido en sueños (Punter 290). "Yo mismo me sorprendí de lo que había exhumado", se dice el protagonista tras la amenaza de golpes que profiere mentalmente al jefe; y, más adelante, cuando afirma que "sería preciso (...) no sólo pegar, sino matar la fealdad de alguien y que saliera una preciosa figura humana

\footnotetext{
53 “a pesar de la adoración real que me acababa de caer encima con la mujer” (27).

${ }^{54}$ Entre las primeras anotaciones del protagonista aparece: “'Cuando el niño llora no cabe en el departamento. Y el niño sigue llorando y el departamento siempre igual a sí mismo'. Miré a mi alrededor y vi que había existido un error de cálculo desde el principio. Piso: metros lineales tres cincuenta. Mesa, no sabía por qué, dos metros. Niño, los centímetros que debería medir en su etapa más los del alargamiento progresivo. Sobraba, seguí calculando, poco o nada para un llanto. (...) 'Y ahora será necesario que ocurra algo - continué- algo de la naturaleza de los milagros'. 'Porque si el departamento no se alarga el niño tendrá que acortar'. Le vi de pronto iniciar el proceso absurdo, pero completamente imprescindible, que lo hacía decrecer hasta lograr su tamaño primitivo. 'Debería volver al semen' (...) 'Entonces ¿será preciso suprimir al niño?’ Me quedé fascinado sobre la concreción de aquella voluntad exterminadora” (18-9).
} 
por debajo", no lo dice él mismo, sino que lo coloca convenientemente en boca de la desconocida (Somers 38). Esta inconsciencia del personaje se asocia con la imagen del árbol recurrente en el relato, "cuyo simbolismo vegetal indica un estado profundamente inconsciente" (Jung 60).

Para el lector la aparición del árbol es una nota disruptiva que desencaja el flujo de la historia, típicamente expresionista en su deformación de la realidad: "Un árbol que había en la acera se me quedó mirando. Hacía tiempo que teníamos formada cierta alianza de origen desconocido. (...) Mi loco de pelo verde nunca me falló. Y esto lo subrayo desde ahora" (Somers 18). Como en la metáfora del hombre "con olor a hoja seca y cara de pájaro", ambas tienen en común el ser imágenes que retrotraen una relación primitiva con el mundo. Esta llamada del texto al plano simbólico del relato cobra sentido en relación con el proceso psíquico del personaje, que efectivamente "recorre una jornada retrospectiva" en aras de darle sentido a su vida (Moraña 190). El árbol junto con la mujer imaginaria son símbolos de una individualidad en gestación, razón por la que ambos representan para él un gran secreto. ${ }^{55}$ Luego, a diferencia del tratamiento de los personajes, la metáfora de árbol se humaniza. ${ }^{56}$ Interesantemente, el árbol, que representa el núcleo todavía inconsciente de la personalidad, ${ }^{57}$ se asocia aquí

\footnotetext{
${ }^{55}$ La complicidad que mantiene con el árbol es secreta, "no era preciso explicarle nada. Bastaba con aquella confabulación como de locos que han sido separados por el grado de su enfermedad, pero que se frecuentan por las cercas del hospicio" (18). Más o menos lo mismo sugiere de su relación con la mujer cuando dice que era algo que se le entregaba "en la forma de un campo interior completamente secreto" y añade "la dulce zona terminada de abrirse para mí solo me acariciaba desde su ingenua sensualidad como una amante sin historia" (45).

${ }^{56}$ Evelyn Picón Garfield ya ha advertido en su estudio de "La metaforización de la soledad en los cuentos de Armonía Somers", sobre la alternancia de que los textos de Somers se sirven "entre la personificación de lo no-humano y la deshumanización del hombre" (25).

33 “Los árboles tienen individualidad. Son, por lo tanto, un sinónimo de personalidad. (...) Es el prototipo del yo, un símbolo del origen y del fin del proceso de individuación. (...) expresa el núcleo inconsciente de la personalidad" (Jung 60-1).
} 
de continuo con la vejez, con la que el personaje se identifica a lo largo del relato. ${ }^{58} \mathrm{La}$ mujer, en cambio, se asocia con la juventud, pues a ella narra sus experiencias más significativas de la infancia y de la adolescencia. Podría decirse, entonces, que la individuación del personaje se plasma en la dualidad arquetípica del senex y el puer, el viejo y el niño, manifiesta en el contraste de imágenes estancas (vacío, seco, nada, muerte) y en imágenes de acción y/o fluidez (río, música, automóvil, ferrocarriles) propias del entusiasmo juvenil. El relato da cuenta de cómo estos dos arquetipos representados por el árbol y la mujer, aunque están estrechamente relacionados, aparecen como fuerzas antagónicas en el protagonista, que mientras afirma ser "más viejo" que su madre, se embarca en una profusa reproducción del pasado, afianzado en una actitud defensiva, monologizante, "sin comas ni puntos", a la velocidad propia del puer.

Hasta cierto punto el árbol y la mujer conforman su sistema escapista. Los relatos de sexo, traición y crueldad junto con los de la infancia melancólica son su subterfugio o pretexto de huída del presente: “un puente subterráneo (...) a la soltería que perdí como al país de nunca jamás y su aventura permanente” (Somers 58). Pero ella le advierte del peligro de vivir colgado del recuerdo, en la falsa creencia del "infinito", como "un ahorcado" (Somers 70). Poco después el árbol reaparece esta vez “como un árbol muerto" (85). Este es el preámbulo de la difícil conjunctio del abrazo de "la mujer joven y el árbol viejo", 59 entiéndase, senex y puer, y en el que el antagonismo

\footnotetext{
58 "Un árbol sin hojas" (8); "Un árbol viejo" (18); “yo que siempre fui más viejo que ella”, "con mi llanto de viejo" (24); "No, no quiero pensar ahora en ellos, la mujer joven y el árbol viejo" (80); "como un árbol muerto" (85).

59 "De pronto, y siempre en su temperamento sorpresivo, se abrazó al tronco de un árbol y dijo, con vehemencia: - Ya sé, lo he descubierto al fin, y este árbol será mi monumento. — ¿Qué cosa? [replica él]
} 
de los temperamentos se reconcilian por más que él a toda costa intente evadirlo. ${ }^{60}$ Es, asimismo, el principio del descalabro del sistema escatológico que hasta ahora ha privado en el protagonista, desde las imágenes de muerte, vacío y vejez, hasta las visiones apocalípticas cargadas de imágenes sexuales de abuso y sacrificio, para dar paso a otras de vergüenza y compasión. Las miradas retrospectivas del personaje a su juventud sugieren entonces que él siempre ha sustituido lo metafísico por lo físico y que esa sustitución ya no es un medio eficaz para el autoengaño o que ya no hay autoengaño posible:

$[\mathrm{H}] \mathrm{e}$ fornicado tanto como para recrear la especie si mis productos se hubiesen podido guardar en botellas. Mi tragedia sexual consiste en que no puedo esperar. Yo estoy completamente solo en lo mío y la mujer con mi defecto no aparece. Pero como soy gentil me multiplico. Lo que quiere decir que, por cada vez, yo soy cuatro hombres. Esa repetición va a aniquilarme. (...) Y además estoy cansado de prodigarme en vano. (...) Escribo esto y lo sé, sé el final, porque desgraciadamente lo recuerdo todo. (...) Y otras que van a ocurrir ya las estoy rememorando. Sé, por ejemplo, cómo voy a lanzarme ahora a mi noche conyugal y el número de veces de mi sacrificio. Y que cerraré los ojos como siempre para inventar una mujer (...) la sonrisa del goce inminente (...) Pero que tampoco sucederá, sino lo único posible. (Somers 93-4)

Si hasta este momento el protagonista permanece renuente a vivir en el presente, tomado por la imagen del puer aeternus, la renuncia de la mujer (su despedida) supone al fin una soledad y un reposo que tornan la escritura escapista a la confesión y a la

\footnotetext{
-Que lo tuyo no era odio, sino piedad, una piedad sin remedio. — Nunca - grité- (...). - Y sin embargo quiero que este árbol lo atestigüe -insistió en seguir afirmando-. (...) lo tuyo es con dolor, los amas desde el odio. Y si no fuera así no los tendrías tan adentro. -Esos son mis enredos subterráneos —aduje mal que mal- y suelta ya ese árbol. (...) ella no tenía derecho a penetrarme de aquel modo, a saber más de mí que yo mismo. O quizás, concluí al fin, estuviese en eso nuestra clave, que ella me sorprendiera así, sin llamar, sin anunciarse previamente, en el huerto cerrado de mi ira. - Está bien (...) si tanto te gusta ese árbol, trato hecho, que sea tuyo. Y me fui (...) como vencido por su espada" (82-3).

60 "No, no quiero pensar ahora en ellos (...). Pero es que pasan por mi cerebro, lo atraviesan como a esas esculturas modernas llenas de agujeros que no nos cierran el paso como las de antes, que nos dejan caminar adentro" (80).
} 
profecía, pero a una que se ajusta a la realidad y no al plan utópico de la mujer ideal o del Don Juan invencible. Esto coincide con la toma de conciencia del senex, en tanto que la fantasía del infinito o de lo repetitivo sin fin desaparece y surge en su lugar la del instante (lo perecedero): "Y de pronto vine a saber cuánto puede perderse en este mundo cuando una flor cae al agua o una pluma en el campo" (94). La aparición del viejo vagabundo en este punto es reveladora porque confirma el intento del personaje por comprender su pasado y sus efectos en el presente. ${ }^{61}$

Según María Zambrano, este “enfoque en el 'antes' y no en el 'después' es (...) el factor que distingue a la literatura apocalíptica de la utópica", en el sentido de que la novela no trivializa el pasado del personaje, sino que le da, aunque por medio de una experiencia excesiva, los medios necesarios para conocer sus límites (173). Esta valoración conduce a un clímax en que el protagonista a manera de evento epifánico sufre la agonía y el parto doloroso de su "razón" pero para comprender que el estado de horror es parte sustancial de la vida, y que el mundo es un equívoco donde las almas siempre están a distinta altura, condenadas al desencuentro (Somers 45,98$){ }^{62}$

La correspondencia entre senex y puer, la síntesis de experiencia y actitud mutuamente influenciada, constituye así el cruce del umbral o la iniciación cumplida. ${ }^{63}$

\footnotetext{
${ }^{61}$ El viejo lo coloca de frente ante el miedo como un hecho común, desprovisto del peso que le otorga el personaje: "Su miedo (...) Et "ben" quoi? Cést pas moi que l'inventé..." (97). Apunta Jung que "La figura del viejo sabio aparece (...) en situaciones en las que se necesitaría una opinión, una comprensión, un buen consejo, una decisión, un plan, etc. que los medios propios no podrían proporcionar. El arquetipo compensa este estado de deficiencia espiritual, por medio de contenidos que llenan los huecos. (...) La compensación, en este caso, no se realizó por la obtención, por parte del sujeto (...) de aquello que le parecía deseable, sino porque le enfrentó a un problema" (21).

62 "No importa — dije al fin para neutralizar al fabricante de hechizos-. Es que tendremos el corazón a distinta altura como lo supe de otra cosa tras una puerta hace miles de años, y esa será la causa. Sí, un corazón que no coincide, y de ahí vendrá todo...”(101).

${ }^{63}$ La noche que parí yo era hombre. (...) Tan hombre que mi sexo, que desde los primeros años había venido molestándome con su exigencia, supo gritarse un no a sí mismo como si comprendiese que el
} 
La aparición del símbolo de la individualidad lograda cobra forma en la imagen del árbol, que aparece significativamente solo, apuntando a su sentido de unidad. ${ }^{64}$ Esta unidad debe comprenderse en términos de un estado incierto e inestable, como expresa el protagonista, emulando el trabajo del equilibrista, que se balancea entre lo novedoso y lo definitivo, siempre cambiante aunque único en sí mismo. ${ }^{65}$

\section{Heterogeneidad}

Tanto en el Bildungsroman del gótico femenino como en el proceso de individuación del protagonista de De miedo en miedo... ocurre una inversión de expectativas en el momento de la epifanía, pero mientras que en el gótico femenino la inversión obedece al punto en que la heroína descubre que este "otro" misterioso al que ella ama, la ama a ella también, el protagonista aquí por el contrario se halla solo, "sin respuestas en las que encallar" (Williams 144, Somers 99). La novela no ofrece el tipo de revelación amorosa que el gótico femenino propone, y así no hay un final que culmina en ganancia, ni tampoco, en pérdida. ${ }^{66}$

fenómeno aquel no le concernía. (....) Parí mi dolor de haber nacido. (...) Alguien siempre distinto desde el nacer, pero que de pronto vino a cobrar un rostro definido" (99).

64 “-Nadie (...). Sólo el árbol” (99).

${ }^{65}$ Ya el protagonista, en su carta al cura, le preguntaba "Cómo lo hizo, sí, cómo se las arregló sobre aquel plano inclinado que acabo de descubrir recién ahora en la cámara lenta. Y no sólo a fin de no caer, sino también para que yo jamás lo viese como un equilibrista" (47).

${ }^{66}$ Afirma Anne Williams, en su ensayo "The Male as 'Other"” que en el female Gothic "Like the Male Gothic, it ends in loss, and in considerably muted expectations concerning life in the 'real world'. But the Female gothic, following the myth of Psyche, tells of paradise gained" (146). Así, el protagonista, tras sufrir su parto le comenta al oído a la esposa dormida: "yo acabo de alumbrar en una virginidad que no hemos, tú y yo, compartido nunca. Y ahora me levantaré como pueda, agarrándome de las paredes o del aire, y me pondré a describir la cosa, aunque sólo sea para los ahogados y los peces de allá abajo que se disputan mi corazón en una guerra helada. Pero nunca para tus ojos, nunca para tus oídos despiertos" (Somers 100). 
El relato invierte el tropo del gótico femenino en que los amantes rememoran los tipos comunes de "la Bella y la Bestia", donde "el 'otro' puede parecer un monstruo (...), pero eventualmente se convierte en un esposo amoroso, bajo los efectos de la transformación amorosa" (Williams 145). La orientación escatológica de la novela da cuenta de que la transformación del amante no asume el carácter sublime que eleva al sujeto por encima de la experiencia terrenal, colocándolo en un mundo ideal de bienestar absoluto, sino que propone una poética de de-sublimación y deformación estética, en el que la naturaleza sufre asimismo una transformación (Murphy 59). ${ }^{67} \mathrm{El}$ caso de la descripción del clímax femenino de la esposa, el éxtasis, lejos de ser una belleza exultante que se confunde con el memento mori —como en el barroco-, la mujer aparece como una sardina en retorcijones, una imagen más bien grotesca. ${ }^{68}$ Tampoco se corresponde con ningún modelo de belleza afrodítica, de sensualidad y voluptuosidad, sino con un cuerpo insípido, desprovisto de todo atractivo, "Como una flor del algodón, sin peso y sin olor, sin nada más que una semilla dura” (77). El motivo de la pasión se retoma pero para torcerlo, de forma que el individuo humano (la esposa) sufre también una reinterpretación despojada de toda noción idealista, convertido su ser en una mera cosa fría y seca, inodora. ${ }^{69}$

\footnotetext{
${ }^{67}$ Las imágenes escatológicas forman parte de la estrategia del expresionismo de vanguardia, que persigue la de -sublimación y y trastrueque de códigos y tropos poéticos convencionalmente dominantes, tales como el tópico del amor idealista y romántico y el mito de la unión idílica. Según Murphy, "This serves both to defamiliarize vision and to unlock conventionalized constructions, while encouraging the reader towards a free play of associations (...). (...) rather than diverting attention away from reality towards an idealized and aestheticized real of the sublime beyond, the avant-garde's aesthetics of "desublimation" enforces a close examination of the world (59).

${ }^{68}$ El personaje admite que aunque no cambie el estado de las cosas, tendrá que seguir inventándose una mujer "que no me salga con gemidos ni movimientos de sardinas en la red ni caras descompuestas" (94).

69 "Ella olía a rosas de la nada" (101).
} 
La representación no-natural de la naturaleza se extiende asimismo a la autoreflexividad de la escritura. En consonancia con la perspectiva expresionista de vanguardia, el personaje marginaliza y deconstruye la narrativa como medio que pueda servir de alivio o consuelo, y lo postula en cambio como expresión urgente de la existencia problemática y dolorosa del hombre (Murphy 60) ${ }^{70}$ Si bien esta autoconciencia se asocia con la escritura modernista, lo postmoderno aquí se refleja en la tendencia a examinarse a sí mismo, como observamos atrás, enajenado del mundo que lo rodea. Esto se demuestra cuando el personaje emplea la metaficción como vehículo epistemológico de autoexploración más radicalmente, en particular en su exigencia al lector, cuya participación en la búsqueda de sentido y de auto-conocimiento debe hacerla, según el personaje, “con sacrificio, como quien buscase una pequeña tuerca entre montones de chatarra" (Somers 67).

La recodificación de la escritura que propone el protagonista apela en cierta forma a lo que Richard Murphy identifica como la función "iconoclasta" típica del expresionismo de vanguardia. Allí, la estética de de-sublimación reinterpreta cínicamente los presupuestos de construcción ideológica y discursiva en el relato dislocando la imagen de la ficción cosmogónica en búsqueda de la "totalidad", "llevándola mucho más lejos" (59). Esto mismo ocurre en la concepción de la novela del protagonista, quien impúdicamente pretende incluir lo inservible, lo insignificante,

\footnotetext{
70 “Estrujar los papeles, arrojarlos al río (...). Las palabras seguirían el destino cloacal que yo jamás les hubiera dado por el sólo hecho de ser engendros de mis entrañas, alumbrados en la desolación del desierto íntimo" (19). "tomamos la orilla del río los papeles que arrugo y tiro ahí no importa que se pierdan pero es mejor que no decirlo el tiempo saca a la luz de nuevo todo" (53). "y como una aguja en el corazón, el deseo de escribir largo a mi hermano. Pero una carta es algo organizado. Y yo no podía sino gritar palabras sueltas" (79).
} 
lo más desgastado y vergonzoso, hasta lo que no se hizo. ${ }^{71}$ Esto último, unido a la idea de no tener que "ser escritor", es, asimismo, una llamada del texto a un tipo de construcción narrativa cuyo mundo "orgánico”, se corresponde más bien a la condición de abandono espiritual del ser humano (Murphy 59).

Pero esta aporía que supone la ambición del protagonista de querer abarcar más allá de la totalidad de la mano de un tremendo vacío espiritual se resuelve en la novela por medio de la imagen de la heterogeneidad. Ciertamente, la desconexión del personaje de los hechos y la atribución de las fantasías violentas a otros oculta una tendencia en él a ponerse del lado de una voz homogeneizante o unívoca que desecha el resto de las posibilidades, también patentes dentro de sí. ${ }^{72}$ La aparición de dobles capaces de articular las voces que él en sí mismo tiende a acallar es síntoma de una heterogeneidad que él en el fondo añora y necesita para sentirse vivo. ${ }^{73}$ Esto sin duda se aviene a la experiencia del llamado "terror sublime" del gótico de postmoderno, en que la "destrucción del todo" y reinstauración del "la heterogeneidad pura" se obtiene por medio de lo "irrepresentable", reconocible en los sentimientos de terror que el

\footnotetext{
${ }^{71}$ El protagonista, en plática con la mujer, le expone una teoría hipotética de la novela en la que se desecha la concepción del modelo realista a favor de una nueva aproximación a la realidad capaz de incluir los objetos de más inefable naturaleza, y "para la que no se necesitaría ser escritor ni nada de eso. Que se pudiera componer con otros elementos más a la mano de cualquiera, por ejemplo de dibujos mal hechos, cajones llenos de esas cosas que significaron alguna vez y luego se hicieron basura. Trapo quemado de vida que se gastó diciendo buenos días a todo el mundo, gente fotografiada en el momento de perder el orgullo, con la boca, las uñas y los ojos agarrados al aire al errar un pasamanos. Y muchos materiales más... Quién sabe si con largos períodos en blanco" (66).

${ }^{72}$ El personaje admite de alguna manera la herogeneidad que pugna dentro de él, cuando en carta al hermano le dice: "qué cosa tan difícil ser uno y ser los otros, ¿no es cierto? Y es por eso que si no funcionara el ángulo tierno e indefenso del corazón donde yo te guardo, yo saldría ahora a gritar algo sucio por la ventana" (90).

${ }^{73}$ Concuerda con el gótico postmoderno, el cual se considera "a link to the lost sense of heterogeneity that is vital to the subjective self" (Beville, Gothic/postmodernism 56).
} 
personaje padece a lo largo del relato y más profundamente hacia el final, cuando dice

literalmente "parir" su "terror", su “desborde final de desesperación” (Somers 102).

La imagen de la prostituta concentra la heterogeneidad ganada en el

protagonista. Tendido en la cama y sosteniendo un diálogo con la esposa, ausente en su profundo sueño, el personaje recupera la débil fe en el misterio del encuentro de dos seres tan dispares ${ }^{74}$ en lo que parece una visión de la proto-'mujer de la vida' ancestral, arquetípicamente delineada en la generosidad impúdica y desvergonzada, dispuesta a ofrendarse a cualquiera. ${ }^{75}$ Esta aparición, de nuevo, evoca el terror sublime gótico y la relectura de iconos propia del expresionismo cuando remite al miedo extremo a la muerte sin aspirar a la divinidad. La ironía de la heterogeneidad ganada es la certeza de que el tormento psicológico y físico constituye, a la postre, la verdadera base de la dignidad humana, y que el sinsentido es parte del tránsito, ${ }^{76}$ razón por la que la historia se continúa, apuntando a un sin fin, en un remolino de lobos que fluye río arriba abarcando toda la ciudad. ${ }^{77}$

\footnotetext{
74 “Tan desde lejos que viene un hombre a una mujer, aunque parezca que se la presentó un amigo, que la encontró paseando por un parque. Debe ser que nos envía ese olor mucho antes, y nosotros con la nariz sobre el rastro busca que busca" (101).

75 "Fue entonces cuando la puta camuflada en la portería quiso que yo supiese que ella sí era capaz de estar siempre. Quizás por ser vieja como el mundo y por eso tan fiel, tan sin asco para cualquier cosa... Salió, pues, de la mitad de una pared que se abrió para que ella pasase y volvió a cerrarse (...) Parecía llevada en andas por su propio destino de horizontalidad perfecta, y ella se lo dejaba hacer con orgullo, largando como estela un olor a barcaza veterana calafateada al nuevo, siempre para la penúltima reflotadura" (102).

${ }^{76}$ A la esposa: "O quizás — concluí casi besando su rostro inocente- ya estuviera escrito. Que fuésemos los condenados a andar en este mundo con los zapatos que debió calzarse otro: tú, yo, todos. Y que de ahí provenga nuestra manera extraña de andar así, renqueando, desde la vida equivocada hasta la siempre segura muerte, con este miedo tan atroz de sabernos perdidos" (102).

${ }^{77}$ La novela culmina con un fragmento de un poema de Vallejo. Esta inserción corresponde a un intertexto específicamente gótico postmoderno, en tanto que "The complexity, the confusing density of the narrative frames, do not (...) restore a moral order, or explain a mistery, but suggest that the human condition is as inescapable as the narrative labyrinth itself, a relentless chain of cruel events without purpose, unity or meaning" (Botting 108).
} 
La novela da cuenta de una subjetividad expresionista gótico-postmoderna, una vez que se "invierten irónicamente los ideales del romance y sus efectos homogeneizantes", y "todo está sujeto a la interpretación subjetiva del personaje", quien, por medio de la experiencia de angustia y terror, podría decirse, logra reconciliar las oposiciones binarias entre el "yo" y el "otro", lo consciente e inconsciente (Botting 108, Beville, Gothic-postmodernism 47). Sin embargo, como en la novela anterior de Somers (La mujer desnuda, 1950), la obra culmina en un final abierto, especialmente si se atiende al carácter "informal" de las memorias, a la novela no creada por un "escritor", tal y como el mismo narrador hace referencia. Según Umberto Eco, en este tipo de producciones "informales", hay una exigencia de concluir el hecho artístico en una estructura definida,

de no determinar al espectador a aceptar la comunicación de una configuración dada, y de dejarlo disponible para una serie de goces libres en los que él escoja los resultados formales que le parezcan oportunos. (...) En este ofrecimiento de posibilidades, en esta petición de libertad de goce, están la aceptación de lo indeterminado y una repulsa de la casualidad unívoca. (231)

Esto se aviene a la estética expresionista en distintos aspectos: tanto en el rechazo de un sentido unitario, como en el gusto por "mostrar la subjetividad como un proceso en continuo desarrollo fundamentalmente incomprensible" (Murphy 17). Efectivamente, el final de la novela no ofrece una solución al problema. El protagonista aparece de cara a una esposa que sigue sin entenderlo y sin participar de nada de lo que acontece en él. No hay opus, no hay conjunctio amorosa. Como advierte Murphy en relación con la prosa expresionista de vanguardia, "el conflicto no se desarrolla, sino que está amenazadoramente de principio a fin, sin resolverse" (19). La construcción del personaje 
es inorgánica, porque algunas veces articula su voz real, otras aparece como un tipo abstracto. Todo lo cual se refleja en el lenguaje, ya que el protagonista emplea alternativamente diálogos, monólogos interiores, saltando de una forma a otra sin aspavientos. Esta irresolución del conflicto, unida a la alternancia entre abstracción y realismo, es lo propio de expresionismo y adquiere, asimismo, tintes góticospostmodernos por el grado de ambigüedad y plasmación de un estado irrepresentable. 


\section{Capítulo 4. Terror prototípico y postmodernidad en "Un retrato para Dickens" (1969)}

Como contrario del mal, el bien le es, en el sentido que lo son todos los contrarios, equivalente.

Un retrato para Dickens es un texto intrigante en términos de su proximidad al gótico. Fuera del terror, la atmósfera, los temas y motivos obvios del género, las circunstancias que rodearon su composición y publicación generaron incomodidad y desconcierto entre críticos y lectores. La fotografía reproducida en la portada corresponde

“a una niña muy especial” que ella misma obsequia a la autora en edad adulta, y cuya vida sirve de base para la recreación de la novela (Risso 268). Seis meses después de su publicación, no obstante, el modelo “murió (...) desbarrancándose desde una salud exultante" (269). Somers confesó su temor hacia esta "nouvelle" que, según dijo, no volvería a releer jamás. Cuando a fines de ese mismo año contrajo una rara enfermedad que la mantuvo cerca de la muerte, la atribuyó al hecho de haberse "metido con el diablo" en la elaboración de esta novela (269).

La figura del diablo y lo diabólico resultan asimismo ineludibles en términos del impacto de la obra. Para los estudiosos, las múltiples asociaciones de los intertextos y la confesión de la niña huérfana dificultan la negociación de un significado último o percepción de conjunto, mas todos coinciden en una deliberada línea de sentido entre las historias, una suerte de "obsesión por lo oscuro y lo diabólico" presente en toda la novela (Potvin 228).

Sobre el género de Un retrato... se ha debatido numerosas veces sin llegar a una conclusión sólida. Los críticos mantienen una postura generalizada en torno a elementos 
heterogéneos que ubican al texto en el campo de la parodia y la postmodernidad, con incursión de lo fantástico, la sátira, el carnaval y, el folletín, entre otras categorías. Muchas de estas clasificaciones pueden justificarse en el relato, pero echan en falta el modo gótico y expresionista de la obra, y su relación con la innovación estilística de su narrativa. Este capítulo se concentra en los rasgos inadvertidos de enclave gótico y expresionista-postmoderno más importantes de la novela mediante la intrincada subversión de las categorías del mal y del bien, de la fe, de lo grotesco y lo sublime, y la dicotomía realidad - ficción.

\section{Metaficción gótica}

Un retrato para Dickens combina audazmente tres narraciones: el relato de Tobías o Libro de Tobías, tomado casi textualmente del Antiguo Testamento; la confesión de una niña huérfana, y, por último, el relato de un loro, reencarnación del demonio judío Asmodeo. La historia bíblica, siempre en letras cursivas, alterna episódicamente con el testimonio de la niña y aparece señalado bajo el rubro de "Documentos" al margen izquierdo del texto. El relato del loro-demonio, categorizado de igual manera ("Documentos"), y titulado "Los rollos de Asmodeo", aparece sólo al final de la novela y está dividido en veinte secciones con números romanos. A estos intertextos, diferenciados del relato de la niña, se le suman, asimismo, fragmentos de un manual de panadero titulado "El Pastelero y Confitero Nacional” (cartas del autor, recetas). Este tejido de narraciones distantes en tiempo, perspectiva e intención, reunidas bajo el título de la novela que hace referencia a Dickens, y la fotografía, es el conglomerado intertextual que compone Un retrato para Dickens. 
Claramente las referencias intertextuales son complejas y variadas, abarcan desde el texto bíblico hasta la narración moderna. Sin embargo, todas las narraciones e intertextos comparten un aspecto en común: son temáticamente góticos. Desde el eco de Dickens y la alusión Oliver Twist (la temprana inocencia rodeada por fuerzas oscuras); la persecución brutal de Tobías y su rol siniestro de enterrador, pasando por la confesión de la huérfana en la cárcel, hasta la historia del demonio Asmodeo, los signos del terror aparecen constantemente asociados a las ideas de fe, imaginación, miedo y muerte.

Otro rasgo gótico corresponde al despliegue de la arquetípica dualidad del mal y el bien, distintivo en el contraste entre del relato bíblico y en la narración final de Asmodeo, con el relato de la niña de por medio. El gótico opera desde el ideal de la moral cristiana para subvertirlo y presentar, en cambio, una moralidad de naturaleza fundamentalmente plural. En los textos góticos y góticos-postmodernos, notablemente a partir de Drácula, la figura de Dios siempre se presenta como un ente absoluto y totalizador, mientras que el demonio encarna la idea de la identidad plural e incluso el de la no-identidad (los casos de posesión y pérdida de la identidad de los poseídos). Desde este punto de vista, podría decirse que la intertextualidad tiene un aspecto "diabólico" si se considera que la pluralidad de sentidos y el sinsentido al que apunta la combinación deliberada de textos en la obra, en sus múltiples referencias, recrea una forma de terror en la desorientación e imposibilidad que experimenta el lector de resolver el rompecabezas del texto.

En efecto, si la intención de los intertextos es la de "suscitar la construcción de una potencial arquitectura en la que se sintetizan valoraciones y evocaciones compartidas en (...) la tradición cultural", aquí las convenciones tradicionales a que remiten los 
intertextos, lejos de estar en consonancia con los valores a los que comúnmente obedecen $(f e=$ virtud, niñez $=$ inocencia, diablo $=$ vil $)$ y de proveer una seña interpretativa al lector, lo conducen, más bien, a la confusión, cuando los rasgos que configuran las categorías pasan a ser características de su par contrario (Mendoza Fillola 57).

Un ejemplo de esta confusión producto de la intertextualidad es la clasificación de los textos en la novela. Nos parece obvio que el relato bíblico se designe como "documentos" debido a su carácter histórico o historiográfico. Pero cuando se categoriza de "documentos" el fragmento del manual de "El Pastelero y Confitero Nacional", así como algunas de sus recetas, la categoría documental abarca ya no sólo lo históricoreligioso, sino lo histórico-gastronómico, quedando la gastronomía y el texto bíblico absurdamente relacionados. Esta incongruente situación de igualdad causa mayor sorpresa cuando el título del fragmento del pastelero, "La verdad esclarece e ilumina", así como el tono y los latinismos sentenciosos de la carta, emulan el discurso bíblico en una evocación estilística ridiculizante, llevando la tragedia de Tobías, sugestivamente, al plano anecdótico y melodramático de un mero pleito de derechos de autor.

Al alcanzar la narración final del loro-diablo "Los rollos de Asmodeo", su clasificación como "documentos" causa más bien un efecto de comicidad. La audacia del absurdo pierde aquí fuerzas por la mítica oposición entre el discurso diabólico y el "dictado" por Dios. De igual manera, la aclaratoria del demonio escrita en letras cursivas y los capítulos que le suceden separados en números romanos contribuyen a realzar la parodia entre la legitimidad de su discurso y la de la historia compilada en el Antiguo Testamento. El aspecto oscuro de la reunión del relato de Tobías y del diablo lo 
encontramos, no obstante, en la palabra "rollos" y el paralelismo que ésta sugiere en relación con el libro sagrado. ${ }^{78}$

Evidentemente, si lo histórico, lo teológico y lo gastronómico pertenecen a la categoría de "documentos", y el texto propone el testimonio diabólico como parte de ese conjunto, se sugiere que todos los discursos corresponden, en esta cadena de sentido, a un mismo carácter “visceral”. La novela alude así a que todo discurso histórico, teológico, gastronómico, diabólico, independientemente de la categoría formal a que pertenezca, es producto de la emoción humana, mejor expresado en la imagen de las entrañas del loro y su concomitante torpeza con las palabras. ${ }^{79}$

En este contexto, la distinción entre los “documentos” y la confesión de la huérfana resulta igualmente desorientadora. Su historia sin nombre, interrumpida por los episodios de la historia de Tobías y los fragmentos del manual del panadero traza el vínculo con el título de la novela, colocándola como la historia central de la obra. Paradójicamente, su confesión reproduce los sucesos que la condujeron ese día a la comisaría, apuntando al documento como "transcripción” verídica de la realidad. Y sin embargo, al dar testimonio de sí misma y de los procesos interiores que movilizan una escritura que logre expresar "una verdad que estaba más allá de los hechos comunes", su relato devela un origen profundamente subjetivo (Somers 14). Su testimonio se revela,

\footnotetext{
${ }^{78}$ El título de "rollos" se refiere al "registro" que hace Asmodeo en su encarnación de loro, quien a manera de cinematógrafo graba lo que capta guardando el "rollo" de la película "entre las tripas" (Somers 105).

${ }^{79}$ Parece relevante que el paralelismo de los discursos se sitúe específicamente en las tripas de un "loro". El hecho de que sea el único animal que logre imitar la voz humana, tal si fuera de su mismo mundo, así como de no poder pasar "de la octava frase", hace pensar en que el hombre, como aquél, con toda la inteligencia de su lenguaje, sufre asimismo de una limitación, cada vez que se topa con lo inefable. De alguna manera la novela entrevé en esa "función fáctica" común a ambos una torpeza más honda, como si el habla mecánica y reproductora de frases impensadas encubriese la incapacidad humana de articular lo real irrepresentable.
} 
entonces, doblemente documental: primero como crónica y luego como relato de sus mecanismos psíquicos.

Hasta cierto punto la doble condición del testimonio de la huérfana arroja una luz sobre la naturaleza de los otros relatos en su calidad de registro y confesión a la vez. Podría afirmarse del todo, si no fuera porque la disposición intencional de los textos intercalados entre sí produce la ambigua impresión de estar a un mismo tiempo en presencia de una repetición y de un violento contraste. Obviamente la estructura narrativa de la novela hubiera sido más fácil de construir si las secciones del libro de Tobías no alternasen con la historia de la niña y las partes del manual de confitero, de forma que el relato bíblico se leyera al principio de la obra, seguido por la historia central de la huérfana y concluir con el relato del demonio, este último tal y como aparece en Un retrato.... Pero es claro que esto hubiera neutralizado el efecto de simultaneidad entre los distintos niveles de existencia y perspectivas ontológicas, presentando una simple antología en que la asociación lúdica de textos se pierde en su calidad de bloques o literalidad.

En cambio, mediante una sucesión estratégica, las narraciones se presentan en múltiples formas: la desgracia de Tobías es una tragedia, un melodrama y un cántico; la confesión de la huérfana, una versión o evocación de Oliver Twist, un testimonio basado en la vida real, un capricho del fotógrafo y una invención de Somers. Y, finalmente, encontramos la versión cómica, satírica y melancólica del loro de todas estas historias (incluyendo la del panadero), narradas según lo "registró" con sus ojos de animal, que en realidad son los del diablo Asmodeo. 
Tácticas metaficcionales como éstas sitúan la novela en la escritura postmoderna. La distorsión de las perspectivas tradicionales amén de la parodia y el cuestionamiento a "la inherente ficcionalidad de todas las cosmogonías existentes, meta-lenguajes y grands récits" implica, asimismo, a la estética expresionista de vanguardia, que en esto coincide con la postmodernidad (Murphy). De igual forma, participan elementos góticospostmodernos, como el terror que produce en el lector el efecto totalizador de la obra, que acapara todo sentido racional posible para sí, provocando desconcierto, "as if something outside the powers of our understanding, something which for that reason is unrepresentable in language, is manipulating our imaginative response to the novel" (Beville, Gothic-postmodernism 164). Desde esta perspectiva, el tipo de narrativa que la novela presenta, así como las consecuencias que depara al sujeto en múltiples sentidos, la novela puede ser considerada como un ejemplo de metaficción gótica.

Los signos de la postmodernidad

Entre los atributos postmodernos de Un retrato..., los más sobresalientes son la fluidez de géneros literarios; la aproximación cínica a perspectivas ontológicas; la deconstrucción consecutiva de los grands récits (en este caso, la enseñanza bíblica), y el estilo paródico. Uno de los signos más inmediatos de esta deconstrucción es la distribución fragmentaria de las distintas historias en la novela, la cual apunta deliberadamente a una estructura narrativa que evade una disposición orgánica del relato, incitando a cuestionar las claves "dadas" o aparentemente fijas a que refiere. ${ }^{80}$ Así, pues,

\footnotetext{
${ }^{80}$ Aquí el texto remite a la prosa expresionista, que funciona, "like "the subversive" texts (...), by the combative character of its approach to such fixities", en contraste con la narrativa realista, que narra una experiencia ordenada, cerrada y estática (260).
} 
en la ubicación del relato de Tobías al principio de la novela, discurso convencionalmente normativo $^{81}$, es fácil distinguir un doble efecto. Por un lado establece un patrón de percepción socialmente aceptado y proyecta como realidad primera una forma de ver, no obstante tratarse de una realidad específica y limitada a un momento histórico ${ }^{82}$; mientras que, por el otro lado, anticipa la desgracia de la niña (260). De allí, tal vez, que la mayoría de los críticos observe una relación de oposición más que de parentesco, pues aunque ambos relatos dan cuenta de una desgracia, la perspectiva ontológica se revela opuesta. Un ejemplo evidente de esta discordancia es la fe de Tobías amparada en un dios protector y justo, en contraste con la aprehensión de la niña ante la maligna omnipresencia de un "Ojo".

Jorge Ruffinelli describe esta diferencia como un salto que va de "la anécdota sórdida del presente a la exaltación bíblica, (...) de la religiosidad de Tobías a la aterrada intuición de la nada" (276). Claudine Potvin indica, igualmente, que:

Where the Biblical discourse constructs God's benevolence and absolute authority (miracle, abundance, money, cure, faith, descendence), the transgressive speech of the orphan/girl narrator inverts all possible affirmation of truth and originality or authenticity (suggesting, on the contrary, only hunger, poverty, ignorance, sickness, doubt, condemnation, and abandon)”. (229)

\footnotetext{
${ }^{81}$ El libro de Tobías fue escrito hacia el año 200 a. C. y pertenece al género de los relatos "edificantes" de la Biblia, elaborados con el fin de transmitir una enseñanza de carácter moral y religioso. Los protagonistas del relato son los miembros de una familia de la tribu de Neftalí, deportada a Nínive cuando los asirios invadieron y conquistaron el territorio de Galilea (2 Rey. 15. 29). Esta ambientación fuera de Palestina es un elemento crucial de la narración, ya que la enseñanza contenida en el Libro está destinada principalmente a sostener la fe de los judíos dispersos en un ambiente pagano y casi siempre hostil. Para animarlos a mantenerse fieles a Dios, aun en medio de las pruebas, el autor les propone un modelo ejemplar en la figura de Tobit, el padre del joven Tobías.

${ }^{82}$ Así lo percibe Claudine Potvin, por ejemplo, cuando señala que "As intertext, the Bible represents a game of "make believe"" (232).
} 
María Cristina Dalmagro, en su artículo comparativo sobre el Apocalipsis y Un

retrato..., afirma por su parte que "se puede establecer una analogía entre las historias de Tobías y la de la niña, aunque con modificaciones” (225). Ambas líneas de pensamiento apuntan a la capacidad del texto de funcionar como un procedimiento narrativo que recrea simultáneamente discursos en oposición y paridad. Esta ambigüedad es precisamente la que caracteriza la construcción de la novela, una ambivalencia que corresponde específicamente a la parodia.

Según Roland Greene, la parodia implica necesariamente oposición o contraste: es "una forma de repetición con diferencia crítica-irónica antes que semejanza" (1002). De acuerdo con esta definición, la parodia en la novela puede funcionar como una contra-narrativa que deconstruye por vía del terror gótico los valores socioculturales y religiosos del libro del Antiguo Testamento. El término "contra-narrativa" se manifiesta en múltiples niveles en la narrativa gótica y asume, igualmente, una posición dialógica, tal y como se alternan los episodios bíblicos con el texto contemporáneo en la obra. Esta estructura doble en que los dos textos "ni se funden ni se cancelan el uno al otro, sino que trabajan juntos, al tiempo que permanecen diferenciados" (Greene 1002), puede explicarse como un movimiento que no solamente

es (...) una invocación a un conjunto de convenciones que van contra las ideologías o narrativas dominantes, sino también una exploración de lo sublime en relación con la existencia y la subjetividad basada en el concepto de experiencias marginales (...) [esto es,] el terror en sí mismo. (Beville, Gothic-postmodernism 130)

En efecto, el impacto del paralelismo entre el texto arcaico y el contemporáneo en Un retrato...no deviene exclusivamente de la inversión sistemática de los paradigmas de la fe cristiana, sino de lo que puede considerarse una alianza imposible: la unión de inocencia 
y destrucción. "Como contrapunto de lo sublime", escribe Kayser, "es como lo grotesco revela toda su profundidad" (103). Sólo que la vista de un mundo más alto y sobrehumano no tiene su asiento en la imaginación de la niña, sino que ella es el punto de inflexión en que lo sublime se distorsiona y se torna ridículo, donde la figura de dios se vuelve monstruosa y terrorífica, abriendo "las puertas de un mundo inhumano de lo nocturno y el abismo" (103). Este es precisamente el contraste que, según Kayser, "no debería existir”, y que obedece específicamente a las raíces oscuras de lo diabólico, lo infernal, lo grotesco (103-4).

El grotesco, el suspenso y el terror sublime, intrínsecos a la estética gótica, son fundamentales en los esfuerzos de la obra por articular una experiencia irrepresentable. Esta perspectiva se aviene a las formas subversivas del género y, en particular, a la narrativa postmoderna, una vez que ambos transgreden el lugar común de lo sublime, la imaginación creativa y lo sobrenatural en cuanto a divinidad, a favor de una representación siniestra de lo mismo.

El episodio que abre la novela, "La desgracia del anciano Tobías", concluye con el anhelo de muerte y la sensación de un profundo fracaso, ${ }^{83}$ al tiempo que asimila significativamente su sufrimiento al mal cósmico de Job. ${ }^{84}$ Este escenario desilusionado se repite en la historia siguiente con un sesgo más pronunciado. Al respecto Dalmagro señala que en Un retrato... la imaginería del Apocalipsis subyace "como una línea semántica implícita (...) a través de toda la narración” (224). Aunque la niña no se

\footnotetext{
83 "Entonces Tobías prorrumpió en gemidos; y empezó a orar con lágrimas, diciendo: (...) Y ahora, oh Señor, haz de mí lo que fuera de tu agrado (...) porque ya mejor me es morir que vivir” (12-3).

84 "Y al modo que los reyes o poderosos insultaban al santo Job, así a Tobías le zaherían por su modo de vivir los parientes" (Somers 12).
} 
corresponde con la figura de Jesús, ni Asmodeo con la de Satán, algunas imágenes arquetípicas asociadas con estas figuras reaparecen en el contexto de los personajes, si bien con un énfasis en lo misterioso, lo oculto y lo satánico. Así, al principio de la historia de la huérfana se hace alusión a algo mucho peor que la "caída", y todo el lugar y los personajes describen la escena cargada de elementos grotescos, donde lo sobrenatural y la superstición llenan la atmósfera de misterio, preparando la aparición del terror. ${ }^{85}$

También es común a los dos relatos la existencia de una noción de culpa: para Tobías, él y su pueblo son culpables de su propia desgracia: "Porque no obedecimos a tus mandamientos, por eso hemos sido saqueados, y conducidos a la esclavitud y a la muerte, y hemos venido a ser la fábula y escarnio de todas las naciones entre las cuales nos has desparramado" (Somers 13). Lo mismo que para la huérfana: "el asesinato, el robo, los partos callejeros, las grescas de las prostitutas y borrachos, y hasta las mil formas de suicidio ocurridas aquella noche llena de chispas diabólicas, debieron llegar al frenesí por algo que yo creía mi culpa" (Somers 16). Culpa y castigo están proporcionados por una especie de origen "abyecto" en común que les tocó en suerte, algo que se muestra como una extraña relación de semejanza entre el sentimiento de pertenencia de Tobías a una comunidad enajenada y el de la niña hacia un mundo criminal y autodestructivo. En ambos casos este tipo de existencia revela una de las preocupaciones específicas del gótico postmoderno, en tanto que la vida “'significa' culpa: tránsito, evanescencia e identidad heterogénea" (Beville, Gothic-postmodernism 130).

\footnotetext{
${ }^{85}$ Aquello había empezado a parecerme algo peor que mi caída (...). Por primera vez, (...), había aspirado algo que se llama olor a calabozo (...). Y eso me tenía aterrorizada. (...) La rareza de una puerta recibiendo órdenes se desvaneció cuando vi que lo invocado era un hombre que había permanecido en el despacho general como si fuese una parte del todo (...). [El comisario] Arrojaba cuanta cosa encontrara a mano al que se nos acercase. Menos a los que no cesaron de llamar al teléfono, a causa de su posición estratégica invisible, y al Puerta que los atendía recogiendo sus vibraciones como una araña en la tela (Somers 14-6).
} 
Pero esta mutua condición alienada, aunque resulta extraña y desconcertante en sí misma, se hace mucho más vertiginosa en la niña, porque, como se revela más adelante, los hechos en la historia sagrada son apenas sucesos que asaltan los principios en que se apoya el orden moral de Tobías. Como apunta Kayser, se trata de acciones aisladas que resultan absurdas en su momento, como en escenas propias de la tragedia, pero que tienen una finalidad en el relato (311). A primera vista el accidente que sufre Tobías nos resulta grotesco, por parecernos el colmo de una cadena de eventos horrendos, por la injusticia que representa frente a su acto de solidaridad con los caídos. ${ }^{86}$ Sin embargo, este hecho se revierte al final, cuando su visión se restituye, le retornan sus bienes y la armonía familiar se restablece en las bodas de su hijo con Sara. En cambio, el absurdo del mundo enajenado de que da cuenta la huérfana no permite orientación alguna. ${ }^{87}$ La realidad se muestra inaprensible hasta el final, que carece de solución y que está colocada significativamente al principio del relato.

La forma fragmentaria que emplea la novela en los términos no-orgánicos que hemos referido se distinguen aquí como un conflicto que no se desarrolla, sino que está presente de manera amenazadora de principio a fin, sin ofrecer un sentido unívoco de la realidad. De ahí que el lector perciba un terror que va en aumento, cuando ni el desarrollo interno del deterioro y la amenaza, ni la ruptura de un orden moral son capaces de explicar la situación de absurdo.

\footnotetext{
${ }^{86}$ Después del cautiverio, la persecución y el exilio, todavía "fatigado de enterrar [a los degollados por el régimen], se echó junto a la pared y quedóse dormido; y estando durmiendo, le cayó de un nido de golondrinas estiércol caliente sobre los ojos; de que cegó" (Somers 12).

87 "Sí, el mundo tenía algo así como cuatro partes. Una era la tierra, que nunca se piensa como tal porque se halla disimulada bajo mil formas. Otra era el mar, que cuando se lo ve por primera vez puede llegar a matarnos. Luego había unos desiertos hechos para que la alegría los cruzara cantando sin saber lo que le espera del otro lado. Y, lo más poderosamente triste, aquellos seres que le miraron la cara a la incertidumbre" (Somers 30).
} 
Las fuentes del terror

\section{El fenómeno}

La diferencia fundamental que surge a entre el relato de Tobías y el de la huérfana puede verse entonces en la diferencia que existe entre la tragedia y el grotesco. Mientras que en "lo trágico [la realidad] no permanece del todo inaprensible [y] el sinsentido y el absurdo suponen (...) el lugar donde precisamente se inaugura el presentimiento de una posibilidad de explicación del mundo", como de hecho ocurre en la historia de Tobías, en el grotesco, por el contrario, "se trata en primera instancia del fracaso de la mera orientación física en el mundo" (Kayser 311-2).

La teoría de lo “irrepresentable” Jean-François Lyotard puede ilustrar la idea central de esta desorientación característica de lo grotesco. Según él el concepto de lo irrepresentable o lo inimaginable tiene que ver con una subjetividad "interrumpida" o suspendida, producto de la ruptura entre racionalidad e imaginación (Lyotard 210). Esta condición refleja un tipo de experiencia profundamente personal que ya Edmund Burke (1757), en sus investigaciones sobre la filosofía y la literatura gótica, había identificado con la experiencia de terror sublime (Burke 86).

Burke, en su tratado Philosophical Enquiry into the Origin of Our Ideas of the Sublime and Beautiful, recuerda que para referirse a la palabra "terror" los romanos usaron el verbo stupeo, término que en su opinión "designa el estado de una mente fuertemente desconcertada" (estupefacta, aturdida, asombrada) (Beville, Gothicpostmodernism 101). Es revelador que Burke entienda la relación del terror con el asombro como un estado de suspensión del ser en que la mente está completamente absorta en el objeto y no puede comprender racionalmente nada más allá de él. Estar 
aterrorizado correspondería entonces a un estado de estupefacción tal que absorbe la capacidad cognitiva del sujeto y el marco de referencia del que comúnmente se vale la subjetividad, desbordada por el evento, deja al individuo a merced de realidades desconocidas.

Numerosos indicios del terror sublime están presentes desde la atmósfera del calabozo, que la tenía "aterrorizada", tanto que "temblaba cada vez con mayor intensidad", y la actitud del comisario, que aumentaba cada vez más su "asombro", asociados a lo largo del texto con un estado de suspenso o de estar colgado (Somers 14-6, 46). Es relevante notar que el tiempo en estas ocasiones pierde asimismo su orientación o se detiene: "No miré, no oí ni hice entrar a nadie en mí por un tiempo que se quedó sin relojes" $(97) .{ }^{88}$

Más concretamente el terror sublime se manifiesta en lo que la niña denomina "el fenómeno". La incertidumbre de su paradero y la posibilidad de volver orfanato hacen que sufra de una condición "flotante" que le permite desprenderse del entorno y de todos los “problemas”. Camino al orfanato "fue la primera vez que sucedió aquello. (...) al doblar una esquina empezó el fenómeno: sentir que ya no estaba en el suelo, sino que se iba planeando a corta distancia de la tierra (...) pero sin apoyo" (18).

Esta existencia flotante ocupando el lugar de la existencia física puede interpretarse como una inversión casi irónica y grotesca de los cuerpos sin alma de las víctimas de Drácula. En la historia de Stoker, los cuerpos absortos y vampirizados alcanzan una existencia separada de su conciencia racional, lo mismo que el conde, que

\footnotetext{
${ }^{88}$ De manera significativa, el tiempo del terror sublime asume las cualidades del tiempo de la desgracia. Simone Weil observa que en el dolor extremo conduce a "un tiempo no orientado" (121). La niña hace mención en varias oportunidades de esta inconmensurabilidad temporal: "No sé si días, o semanas, o miles de años después, apareció el negro" (28).
} 
puede desafiar las leyes físicas de la gravedad y de la metafísica al evadir todo tipo de reflexión (Beville, Gothic-postmodernism 140). Pero en la niña esta escisión se invierte, ya que no se trata de un cuerpo sin alma, sino de un "alma errante", tal y como ella misma se describe, y tiene su asiento en la experiencia de dolor, la cual, según Burke, es mucho más poderosa que la de placer, y por lo que la razón se rechaza a favor de la imaginación y el deseo (46). ${ }^{89}$

\section{La muerte}

La muerte, en este sentido, recrea el terror sublime doblemente, pues de un lado se asocia con una experiencia que surge del fondo más personal e individual del ser humano (lo sublime) y, al mismo tiempo, con un objeto imposible de representar en la realidad subjetiva. Esto se relaciona sucintamente con el concepto de Sigmund Freud en torno a la incapacidad del individuo de concebir la muerte propia. De acuerdo con Freud, al sujeto le es imposible representar su muerte en el inconsciente y siempre ha de asistir a ella como un "espectador" (29). Esta experiencia de lo irrepresentable o de lo inimaginable puede verse en el episodio del último estadio de difteria de la madre. Allí, la huérfana remite al cadáver "como una forma rígida monumental” súbitamente "deshabitada", cuyo vuelo centrífugo del alma hacia el espacio se invierte inusitadamente, fugándose el alma "hacia adentro de la boca", como clausurada e inaccesible para siempre (97). Ante tan siniestra visión la huérfana concluye que "No había medio de concebir la realidad" (96).

\footnotetext{
89 "Lo practiqué primeramente con los ojos cerrados, luego haciendo intervenir las cosas. Era simplemente cuestión de intentar un pequeño esfuerzo y desprenderse. Al fin se manejará quién sabe qué dispositivo interno de dirección, y ya no más problemas con el cruce de calles, con subir aceras y umbrales" (18).
} 
El fin de la vida como una realidad imposible de aprehender, aparece asimismo reflejado en uno de los motivos centrales de la obra, condensado en la imagen del moribundo. La niña logra articular esta contemplación en la figura del padre:

Era el sentenciado a morir, qué cosa tan solitaria y fascinante al mismo tiempo. (...) Los demás ¿qué significábamos al lado suyo? El dueño de aquella pavorosa carta negra nos podría meter en un puño, él sí era capaz de demostrar, muriéndose en cualquier momento, que lo nuestro, algo tan vulgar como el vivir, no tenía más valor que el que pequeño pelo de cuerda de un ordinario reloj cualquiera. (Somers $36-7$ )

Interesantemente, el vivo envidia la muerte en el desahuciado por su capacidad de escape del sinsentido y puerilidad de la vida (Beville 179). La figura concentra asimismo un tipo de existencia equiparable al de la postmodernidad, en tanto que la vida del individuo postmoderno de cara a la muerte parece sólo una cadena de eventos simulados, una vida cuya realidad no se acerca de continuo a la muerte simbólica, sino que es esa muerte simbólica. El terror de lo irrepresentable personifica esta existencia paradójica en la novela en la directora de la tabacalera, cuyo apodo es precisamente "La Muerte", y que de manera específica define la condición del sujeto postmoderno como "alguien que habría existido, o que quizás no existiese nunca" (Somers 95). La muerte en la novela caracteriza al sujeto en los términos postmodernos ya señalados por María Beville en obras contemporáneas, pues coincide con un "sentimiento de disolución y de vastedad, y una existencia irreal e indefinible (49).

Desde comienzos de la narración de la huérfana, la muerte simbólica y la muerte literal están en entredicho. Lo sobrenatural y lo espectral se confunden una misma dimensión de existencia y se ofrece una extraña visión de la naturaleza del misterio de este fin dudoso. En el relato de la fragmentación paulatina de la familia, primero se 
menciona la muerte de la abuela, que valientemente "llamó a los hijos, los despidió (...) y se enfrentó a la aventura" (Somers 17). Luego, en contraste, la muerte del abuelo, “tan poca cosa" que salió como otro "desertor embalado en un cajón sin pintar (...) con cierto aspecto de bote” (17). También la huérfana hace referencia a una especie de muerte de sí cuando dice que "[le] pareció descubrir algo aún sin nombre (...) como aquel nacer en un viaje al morir" (Somers 95, 59). Esta última frase puede considerarse como la premisa del gótico-postmoderno, ya que en el contexto de la postmodernidad, la vida puede percibirse como una búsqueda de "muerte simbólica", una existencia fantasmal o vampírica (Beville, Gothic-postmodernism 108).

Sin embargo es la figura de la madre quien representa mejor esta ambigüedad cuando aparece ya muerta en el calabozo elevando a la huérfana: "liberada al fin de toda complicación terrena, mi madre empezó a levantar con las palmas de las manos bajo mis pies para que yo escalase la muralla divisoria y pudiera hablar de semilla humana a hombre" (Somers 16). Esta posibilidad de que la madre esté allí sin estarlo abre un tercer espacio en la novela en que lo real y lo irreal coexisten legítimamente y no como una realidad utópica. Desde esta perspectiva, la muerte en Un retrato... está presente de principio a fin en la novela como una dimensión espectral y sobrenatural del plano vital. Esto coincide con el postulado del gótico - postmoderno, que afirma que los seres que habitan este mundo "usualmente han estado o están "muertos"” y andan tras la búsqueda de un algo nuevo, “cierto concepto de nacimiento" (Beville, Otherness 121).

\section{La familia disfuncional}

La experiencia de la muerte y de lo irrepresentable están, por tanto, ligadas a un terror que va en contra de lo normal, de experiencias del día a día en las que el ser y la 
imaginación se suprimen comúnmente por vía de códigos morales de la sociedad. En esta línea de pensamiento, la familia disfuncional, tropo gótico que Un retrato... retoma sin duda de la narrativa de Dickens para introducir el ambiente hostil en que se desenvuelve la protagonista, funciona asimismo como ente propicio para recrear los desajustes de la normalidad familiar. No en vano, en particular en Oliver Twist (1837-38), ${ }^{90}$ es en donde Dickens deposita la carga emocional más importante de la historia y la desfamiliarización más rigurosa de la domesticidad (Furneaux 153). La observación se aviene perfectamente con la ambigüedad de la familia en Un retrato..., la cual se describe como un núcleo filial real y ficticio a la vez:

"Edad, diez años. Hoy enterraron a su madre, que no era su madre" (...) “... Un hermano que no era su hermano...” (...) “... Y otro hermano, negro, que tampoco podía ser ni suyo ni del anterior, pero que salió en busca de éste para matarlo, y así lo hizo arrojándolo escaleras debajo de un altillo" (...) "Y la susodicha (horror, yo no tenía ese extraño nombre, pero todo me era igual ya) se tiró al agua, sin pensar en lo que hacía, según declaró, más bien porque fuera caminando hacia adelante hasta donde no hay ya tierra firme...". ${ }^{91}$ (Somers 14-5)

La declaración puede considerarse teóricamente expresionista, ya que la inestabilidad del estatus de la realidad que se plantea, devela la misma condición psíquica de la niña, quien se mueve entre una existencia fidedigna y palpable, y otra ausente, irreal, imaginaria. Al mismo tiempo, la extrañeza ante un nombre que le resulta ajeno y la insignificancia que le concede, parecen aludir a cómo toda la narrativa de que está siendo parte es ilusoria, y a que su experiencia es, en última instancia, irrepresentable. ${ }^{92} \mathrm{~A}$ este respecto es válido

\footnotetext{
${ }^{90}$ Personaje con quien se compara la huérfana en Un retrato para Dickens.

${ }^{91}$ Comillas originales del texto.

92 "Sentí la absoluta necesidad de volver a explicarme, de quedarme sin sangre, si era menester, a fin de que el equívoco se resolviera a favor de una verdad que estaba más allá de los hechos comunes" (Somers 14).
} 
traer a colación lo que Botting señala como un "exceso de lo sublime", una vez que la falta de asidero y de base sólida sobre la cual construir una realidad, verdad o identidad, más allá de la que la narrativa provee, conduce a este exceso o "ansiedad narrativa", característico de la postmodernidad, en donde las cosas ya no son lo que parecen, sino que lo que parecen toma el lugar de lo que son (170). ${ }^{93}$

En este orden de ideas, la entrada al inquilinato puede asimilarse a la del laberinto, cuya incertidumbre ensombrece el recorrido con una duplicidad y ambivalencia incontenibles (Botting 170). Expresiones como "un día infernal", "subió como un demonio", "lleno de chispas demoníacas", etc., dan un cariz diabólico al desarrollo paulatino de este proceso, en que todo se muestra perfectamente normal y sin embargo algo extraño ocurre (Somers 23). La vida y la rutina parecen transcurrir sin alteraciones, "tan inocentemente vestidas de significados comunes que nadie daría nada por ellas", como "un hecho trivial en apariencia", "tan banal" como todos los días (23). Y no obstante, la ambigüedad de los vecinos y la violencia de los hermanos promueven un creciente proceso de desintegración y enajenación en el personaje, para quien no sólo el entorno, sino ella misma se ha vuelto oscura y enigmática. ${ }^{94}$ A este respecto, el espacio físico y metafísico del laberinto gótico funciona como una metáfora de otredad pertinente que se corresponde con el estado mental de la huérfana, ya que como observa Botting, oscila entre la fascinante y terrible experiencia de la incomprensión y un exceso de

\footnotetext{
93 "[There is] not a unity of Word or image and thing, but words and images without things or as things themselves, effects of narrative form and nothing else" (171).

94 “empecé también yo a sumergirme en aquel lago sin fondo al que nunca se entrará con los ojos abiertos" (Somers 26).
} 
imaginación, entre "la suspensión del dominio de sí y la subjetividad que se sabe abandonada a las vicisitudes" (Botting Power in the Darkness, 245).

En efecto, el inquilinato y la gente que lo habita no solo son una fuente de terror externo para la huérfana, sino una amenaza interior en relación con lo que representan para ella, y que la niña formula significativamente en términos de "mentira fantástica":

El inquilino nuevo y su mujer eran unos monstruos a los que les gustaba vivir en seco, y que quizás por esto habían sellado la canilla para siempre. Estuve pensando aún cuánto sería verdad y cuánto mentira aquello. Los abuelos habían salido una lejana vez como a mirar otro mundo y ni soñar en que volvieran. El negro, ${ }^{95}$ capaz de prometerme cierto gramófono $(. .$.$) se había quedado a trabajar de mandadero en un lugar$ cuyas señas mi madre no quiso revelarme. El hombre lleno de tizne amaba a su mujer, y yo hubiera podido jurar que algo me tenía agarrada de los cabellos y suspendida en los aires. (Somers 26)

En otras palabras, el inquilinato, al igual que el laberinto, es una manifestación del miedo de la niña a la otredad concomitante del lugar, su identificación con los seres aterradores que la rodean. Esto nos remite al terror propio de las representaciones del "otro", que en la narrativa gótica asume en ocasiones la figura del doble o del monstruo, y el cual persigue al sujeto recordándole el lado oscuro e irrepresentable de la cualquier visión objetiva.

\section{El Ojo}

La permanente situación de estar al acecho es de por sí uno de los motivos de terror gótico más marcados en la obra. En la narración de Tobías, el terror tiene una fuente específica e identificable, se trata de un gobierno tirano. También Asmodeo conoce el origen de su asechanza: el ángel Rafael, que desde tiempos inmemoriales le "estaba anunciando aquello" (Somers 119). Pero en el recuento de la niña, la vigilancia

\footnotetext{
${ }^{95}$ Se refiere a su otro hermano adoptivo, dos años mayor que ella "fastuosamente negro" (Somers 17).
} 
adquiere proporciones titánicas, de múltiples manifestaciones que se confunden entre sí, tornando el objeto indistinguible y conduciendo a un terror mucho mayor, en tanto que el origen del mal permanece incierto.

La inspectora del "Asilo" es una de las figuras que cumple esta función con mayor rigor, una "especie de híbrido entre el amor y el miedo, el ser que viene a proteger y a aterrorizar al mismo tiempo", y cuyo "cuerpo fantasmal (...) flotaba en el vacío llenándolo de ojos" (56). Cuando la huérfana narra al comisario las circunstancias del crimen sucedido en el inquilinato, lo primero que "ve" es entrar a la mujer a la casa, reaccionando bruscamente, entre gritos de miedo y profunda exaltación (21). ${ }^{96}$ Con el grito, motivo no-verbal de lo irrepresentable propio de gótico-postmoderno, la inspectora personifica el terror sublime por medio de la ubicuidad, una cualidad que excede los límites humanos. El poder de la inspectora, de hecho, se asocia muy pronto con el de una deidad más abstracta, algo que la niña denomina "el Ojo Perenne".

Había, según la huérfana, en todo momento un ojo “enorme (...) [que] no conocía compasión" y que "era capaz de frecuentar de tanto en tanto ciertos sitios" prohibidos, sin saber "con qué motivos ni qué posibilidades", y traspasar los secretos solo "por alguna causa de su conveniencia" $(29,94)$. El ente siniestro ocupando el lugar de "Dios", como se sugiere en la obra, forma parte de la trama gótica convencional en sus esfuerzos por invertir los esquemas tradicionales de representación y moral cristianas, que no obstante aquí rebasan la concepción maniquea, cuando los efectos perturbadores de un "Ojo" se extienden a un campo más allá de lo humano o de lo comprensible (48).

\footnotetext{
96 "Ella era la persona destacada por el Orfanato para ver cómo andaban las cosas, y se nos entretejía en los hilos horizontales y verticales de nuestra vida sin abandonar jamás la trama. (...) Dejar de recordar a la mujer me cayó como el primer alivio con que una hierba curandera nos va quitando algo tan agarrado al cuerpo cual un dolor de estómago" (21).
} 
Toda la novela está recorrida por el leitmotiv de los ojos, propio de lo grotesco: la inspectora vigilaba "con dos ojos saltones posándose aquí y allá en busca de chicos que no están a la vista"; la mujer de la fábrica de caramelos, que miraba a la niña "como una sonámbula (...) sin quitar[le] los ojos de encima"; "la mujer que regenteaba la tabacalera (...) con la mirada al revés" $(91,72,97)$. A la par de esta mirada incisiva encontramos también la falta de ella: Tobías sufre de una prolongada ceguera, y Dios es un “Ojo Perenne" que lo presencia todo aunque "ciego en la timonera" $(48,55)$.

Aquí como en los relatos grotescos, la importancia de la mirada constituye en sí, como advierte Kayser, "un motivo extrañamiento e inquietud", pues, por un lado "nos obliga a reconocer en la visión toda la carga de información recibida por el ojo en su plenitud", y por el otro, admite que la verdadera visión yace muchas veces "al margen del entendimiento" (128). Así la niña, en contraste con la mirada instigadora de las mujeres o la ceguera de un Ojo implacable, miraba, en cambio, "sin ojos", un signo de que la vista está ligada a un tipo de visión que excede el marco sensorial común.

Lo que la niña percibe en la ceguera de Dios es su carácter impasible, similar al de la inspectora. La visión a la que apela la huérfana tendría que estar asociada a la emoción (una compasión que ella echa sin duda de menos de parte de estas figuras), pero también a una mirada alerta, capaz de ver más allá de las apariencias y percibir el engaño, "de ver bajo el vestido la garra antinatural" (Castelli 68). Esto nos lleva a otro aspecto de la visión que se manifiesta en la novela en la narración de la huérfana y en la del demonio Asmodeo (el loro), última parte de la obra. 
La visión diabólica

La relación de la huérfana con el pájaro es primordialmente de complicidad; los dos observan con avidez todos los sucesos del inquilinato e intercambian miradas quedando "privados igualmente del habla" (Somers 36). Lo que es más llamativo, ambos, en calidad de testigos, comparten un gusto por la "producción cinematográfica" que parece reunirlos en la misma visión de "registro" (48). ${ }^{97}$ Esta afinidad es reveladora por varios motivos y encierra una de las claves de la novela relativas al significado del mal, lo diabólico y Dios.

Las semejanzas entre el loro y la niña se acentúan especialmente en la tercera parte de la obra, donde el loro se revela como demonio y narra su versión de los hechos. Sin embargo, al llegar a este apartado, la impresión de las escenas grotescas previas en las cuales se participa del extrañamiento del mundo se atenúa, pues el hecho de que sea el mismo diablo quien habla nos pone al aviso de todas sus posibles artimañas. Asimismo, su confidencia no deja de parecer extravagante y cómica, cuando el propio demonio da cuenta de cierto carácter de aleccionamiento cristiano en su castigo auto-impuesto. ${ }^{98}$

Su relato se torna ambivalente en la segunda parte, cuando ciertas marcas estilísticas y tópicos de la historia se confunden con el de la huérfana. ${ }^{99}$ La narración

\footnotetext{
97 "tenía (...) un estado de curiosidad lindante con el mío”, dice la niña, y añade: "caí en cuenta de que (...) se me habría adelantado como productor cinematográfico"; "tendría la larga cinta de nuestras vidas enrollada en el carrete de sus inmundas tripas" (28).

${ }^{98}$ Asmodeo decide castigarse cuando aun al desmentir la fama de asesina de Sara y burlar el purismo del ángel Rafael, las bodas de Tobías con esta resultan un excelente negocio: "fue entonces cuando a mí me empezaron a corroer las dudas. Porque no bien caí en comparar el morirse en una sola noche de amor de los otros con el salvar el pellejo de aquel modo, y hacerse rico por añadidura, me pareció que yo había perdido el prestigio. $Y$ desde entonces me castigo así, arriesgando, y lo hago como en esta última reencarnación, transformándome en el espejo de un inquilinato muerto de hambre, a merced de que cualquiera meta la mano en la jaula y adiós Asmodeo" (105).

${ }^{99}$ Cuando leemos en la primera línea del segundo apartado: "Ya pasó la tormenta y quizás pueda continuar,
} 
posee entonces una función reiterativa doble: recontar las historias de sus existencias pasadas (comenzando por la historia de Tobías), y, simultáneamente, emular la voz de la niña, causando el mismo efecto desorientador que hallábamos antes entre la historia de Tobías y de la niña, la cual, recordemos, era el de una repetición y un fuerte contraste. En este caso, la diferencia estriba en el tono satírico del loro, el cual, lejos de representar un papel hostil, gana de inmediato nuestra simpatía por la camaradería y el desenfado de sus palabras. ${ }^{100}$

Así, aunque la figura de Asmodeo está asociada a imágenes infernales en el relato de la niña (las garras aprisionando la garganta del padre como un cáncer), y él a sí mismo se llama diablo, su relato difiere del arquetipo diabólico tradicional. En primer lugar porque ha renunciado al oficio inherente a lo demoníaco (inducir a la duda) siendo él mismo presa de esta. Aunado a ello, la conciencia de su fracaso y de su "prestigio perdido" lo ha situado ahora en una posición de mero observador, negado a desatar en los otros el cuestionamiento inseparable de la tentación infernal, esto es, la constante interrogación (Castelli 79).

En esta oportunidad no nos enfrentamos por consiguiente al problema de la dualidad en términos de la moral del narrador. En la novela queda perfectamente claro que son los seres humanos, su deseo de autosatisfacción egoísta y personal, una fuente

pues me han traído de todo, hasta pan con agua", el lector duda de si se trata del accidente de la niña cuando cae al mar, a quien también le dan de comer en el calabozo (106). Marcas estilísticas en las que priva la hipotaxis en un tono evaluativo y perspectiva analítica, con cierta distancia de la inmediatez de los hechos ("Fue entonces cuando..."), repiten el estilo de la confesión de la huérfana de forma idéntica.

100 "Y aquí me he metido a los que salga. Para quienes quieran saberlo vengo de muy lejos, por lo menos de los siete maridos de Sara hasta llegar a Tobías. Yo sé que una amenaza se cierne sobre mí desde entonces. La percibo en breves momentos en que puedo dejar de mirar por entre los barrotes de la jaula hacia el hormiguero del patio y suspender el trabajo. Podría decir también que la cosa va dirigida a mi cuello, la parte más en peligro de un loro que las canta claro, y conozco el por qué, una especie de equivocación que ha venido a costarme tan cara. Pues miren lo que pasó aquella vez: (...)” (Somers 103). 
mucho más maligna que la del diablo, quien los delata y los ridiculiza. Asmodeo expone la maldad de los otros exhibiendo la hipocresía que trasuntan sus actos de bien, su falsa consideración con los demás: “Qué gente rara: cuando el hombre había estado en el suelo durante horas el día de la borrachera, le hubiesen saltado encima aún vivo. Y ahora qué precauciones con el cuerpo muerto" (Somers 117). De esta manera, la novela ofrece una alternativa a la imagen de Dios que subvierte nuestras expectativas del mal y del carácter diabólico que nos es familiar.

Ante el deseo de los personajes de explicar los misterios de la experiencia o de justificarlos por vía de la fe (en Dios o en la creencia de un Ojo), Asmodeo los satiriza y los recuenta irónicamente, invirtiendo las convenciones cristianas o la paranoia gótica en contenidos realista-grotescos. Así, nos parece que la primera historia, la historia del viejo Tobías, ha construido una identidad falsa: el ángel es mensajero de Dios y un criminal, y el loro es el héroe y villano de la contienda. El episodio, narrado en los términos más banales posibles en relación con el lector, emplea un tono gracioso, casi ordinario, particularmente al referirse al ángel como a "un bicho", y coloca el orden celeste a la par del mundo más salvaje y cerril cuando le advierte al ángel que en su acto de venganza darle muerte al loro_ - solo confirma la ley de tiempos primordiales de "Ojo por ojo, diente por diente".

El evento se acerca al punto más álgido del carnaval gótico en el pasaje siguiente en que el demonio, recobrando el orgullo que le es característico, le informa al ángel que aunque ha logrado derrotarlo, le ha contagiado de una "incurable peste", sugiriendo la inevitable contaminación del mundo celeste. Dalmagro interpreta la disputa entre ambos no como "el triunfo del bien sobre el mal", sino como la corrupción del bien por su 
contrario, "dejando abierta la posibilidad de un nuevo ciclo con presencia del demonio" (230). Esta aproximación proyecta un marco de comprensión interesante para nuestro estudio de la novela desde el punto de vista del diseño temático. El tópico del mal invadiendo el terreno del bien, de la oscuridad como atributo fundamental de la existencia de la luz, retoma el tropo religioso y filosófico de la experiencia del terror, un tema específicamente gótico.

Precisamente en este tramo la visión de la niña se hermana con la del lorodemonio, en una percepción del mundo donde los parámetros maniqueos se pierden a favor de la interdependencia de los semblantes variables del mal y del bien.

En efecto, uno de los instantes de mayor extrañamiento es cuando Asmodeo remite a hechos que sólo ocurrieron en los sueños de la niña, en que no solo la distinción entre lo onírico y real se torna ambigua, sino que la relación entre el loro y la niña se devela más profunda, porque en la participación de sus pesadillas comparten un mismo mundo enajenado. ${ }^{101}$ Esto los reúne, consecuentemente, en una misma "conciencia aterrorizada" característica del gótico sublime, comparable al sueño o a un estado próximo al trance hipnótico, y que en la literatura gótica ha tomado tantas veces la forma del "sonámbulo" (Beville, Gothic-postmodernism 27). ${ }^{102}$

En Un retrato..., como en las novelas anteriores de Somers, el sueño es un elemento temático crucial en la estructura narrativa. En esta novela, donde los testimonios obedecen a experiencias y épocas tan dispares, el sueño como forma de ver y

${ }^{101}$ El mundo enajenado tiene "su origen en la mirada propia de quien sueña o sueña despierto" (Kayser $312)$.

${ }^{102}$ Las descripciones que aporta Asmodeo de la niña en este contexto son significativas. Se refiere la huérfana, por ejemplo, "como un fantasma sonámbulo", "como idiotizada"; como "caída de una nube", "con color de ceniza", "tan parecida a una ciudad saqueada" (Somers 108, 113,122, 116-7). 
de captar la realidad, es, sin duda, un elemento cohesionador de la obra y de los personajes, principalmente en lo que tiene de experiencia pesadillezca.

La mutua intuición entre ambos y, en especial, la distintiva importancia que el loro le concede a la presencia de la huérfana, trastrueca las nociones de lo grotesco y lo sublime que hasta ahora se habían sugerido en la obra. Si antes la experiencia de la niña parecía desmoralizante frente al mundo noble y probidad de Tobías, ahora esta, vista a través de Asmodeo, surge como una presencia sublime, una "criatura" "pensante" en medio de "la salvaje confusión", del incesante "fragor de guerra" y la brutalidad del inquilinato (Somers 114, 108). Esta similitud entre ambos se hace más evidente cuando se consideran los rasgos característicos de lo grotesco que comparten: el extrañamiento de lo existente, el terror al vacío, el estado de abandono y la destrucción de la realidad.

\section{Realidad y ficción}

Ahora bien, según Potvin, la versión fragmentaria del loro deconstruye tanto la lectura de la historia de Tobías como la de la niña, invirtiendo las versiones de realidad que ambos postulan (233). Y, no obstante, independientemente de que Asmodeo recuente las andanzas de todos los personajes anteriores y de sus vidas, la afinidad que guarda con la huérfana parece más bien legitimar aún más su testimonio, principalmente en lo que corresponde a esta visión de "registro", donde la vista del engaño "recuerda la verdad", y donde la intención recae en querer mostrar esa farsa (Castelli 86). En este sentido ambos, secretamente o desconociéndolo, forman una alianza deconstructiva del grand récits de Tobías, en quien encontramos un cristianismo cuyo mundo material se vislumbra desde el ángulo de la necesidad y la miseria, considerando apenas ésta la situación más 
desgraciada del hombre. En esto, recordamos a Bataille cuando acertadamente apunta que "sería desacertado afirmar que ha visto lo contrario de lo que es, pero no ha visto lo que $e s "(55)$.

La vida interior del personaje, es decir, su vida allende de las necesidades de trabajar, esto es, su acontecer espiritual, es la versión que el loro delata y que la niña integra en su confesión, que aparece acallada en Tobías por vía del triunfo material manifiesto de Dios. Se trata de una suerte de mística inversa, pues si el santo es quien ve el engaño, en la novela no es Tobías, ejemplo de mortales, sino la huérfana y el demonio Asmodeo quienes lo ven, y quienes, paradójicamente, están más cerca del "halo de la santidad" (Castelli 68, 65). ${ }^{103}$ A pesar de estas diferencias, podría decirse que la novela, sus concomitantes testimonios y versiones, conjuran el drama de la tentación de todos los tiempos (el más remoto y el ahora), pues todos sufren la sensación de desgarramiento (la base del asalto demoníaco), y al igual que el santo, que no puede ser desgarrado, cada cual a su manera culmina "arrebatado en vuelo", "raptado", si bien no siempre por la Gracia (77). ${ }^{104}$

El suplicio de resistir algo que no tiene sentido o que no tiene sentido preliminar, una de las mayores tentaciones dentro de la tradición místico-ascética, logra no obstante mayor concreción, en la vida de la huérfana que en la de Tobías o en la del loro. En

\footnotetext{
${ }^{103}$ Asmodeo descubre la infelicidad matrimonial de Tobías, el desamor de Ana, la iniquidad del ángel, el ardor de Sara, lo que él llama en conjunto el documento del hombre. Su desencanto da cuenta, igualmente, de una interioridad que se echa de menos en la historia bíblica. Por otro lado, la "puja cinematográfica" de la niña encierra el deseo de revelar la estupidez que encubren las insulsas muestras de amor de Gertrudis y reproducir la visión del exceso de la vecina, aparentemente inofensiva, en una película que titularía significativamente "Salvados de la fiera" (Somers 74).

${ }^{104}$ Léase al final de Un retrato... el "Cántico del anciano Tobías", de tono extático. El vuelo de la huérfana, raptada por el terror de volver al inquilinato y desconocer su suerte; y el vuelo del pájaro, más literal e impedido por la jaula.
} 
Tobías el sufrimiento es un sacrificio cósmico auspiciado por el destino común a todos los hijos de Israel: "le glorificaré en la tierra de mi cautiverio: porque ha hecho ostentación de su poder y majestad sobre una nación pecadora" (Somers 129). En Asmodeo el sacrificio es auto-impuesto, ha decidido castigarse encarnándose en un loro muerto de hambre, y por más que anhele salir de jaula, no lo hace (114). La huérfana, por su parte, en palabras del loro y acusado por ella misma en su relato, es "sacrificada" (128). Mientras que Tobías está convencido de que en todas sus desgracias está el espíritu de Dios, y se exime de pensamientos maliciosos, pues todo acabará en "misericordia", encontramos, en el otro extremo, a Asmodeo, convencido de que ya no vale la pena creer ni sentir nada, ya que ni los hombres son honestos, ni tal Dios protector u Ojo que todo lo ve existen (128-9). ${ }^{105}$ Desde una perspectiva mística-ascética, ambos, Tobías y Asmodeo, pertenecen en este sentido a la gama de seres demoníacos, en tanto que los dos incurren en la mayor tentación, a saber, que es la evasión de "no ser tentado" (Castelli 61). Se trata, pues, de una virtud que deja de serlo cuando por deformación se convierte en vicio (exceso).

La intersubjetividad entre el loro y la niña solo puede entenderse en términos ambiguos, en la mutua intuición de una nada que a ambos exaspera pero que cada cual resuelve de un modo distinto. La visión de registro que comparten tiene en común hambre de imágenes ${ }^{106}$, pero allí donde el loro se resigna simplemente a "grabarlas", sin caer en la tentación de su fantasía, en la niña es precisamente quien, por medio de esta

\footnotetext{
${ }^{105}$ Para el loro-demonio la humanidad entera es primordialmente hipócrita, y este es uno de sus mayores desengaños: "yo mismo me hice animal de jaula, por imitar a los malditos hombres que, mirados de lejos, parecían tan libres" (121); y Dios un ser para el que "todos somos muñecos" (120).

${ }^{106}$ Asmodeo se dice "estos silencios sin imagen son mi muerte", "me trago sus historias a falta de comida" (Somers 109, 125). Y la niña se deshace en búsqueda de imágenes de algo llamado bizcochuelo: "casi llegué a morir de tanto pensarlo" (el subrayado es mío) (Somers 31).
} 
última, transfigura las imágenes de horror dejando de ser puramente bestiales. En este orden de ideas, es la huérfana en quien encontramos el vértigo de la novela, cuando “presume de un mundo más fecundo y más amplio", y es la razón por la que es, también, la más expuesta a padecer las fuerzas que la “obligan a mantener una relación enajenada con el mundo" (Kayser 129-30).

Según Enrico Castelli, el carácter positivo en la percepción de la nada del santo radica en su aviso: la realidad de lo infernal que se oculta detrás del gesto servicial, "la pesadilla de la traición del mundo exterior" (84). Frente a esto, en Tobías hay una usurpación de la nada por parte de un Dios que todo lo llenará, y, en Asmodeo, una entrega al suceder sin reposo, mecánico, confuso de la realidad. ${ }^{107}$ Solo en la niña la nada es acicate de imaginación y de belleza, aun cuando esta culmine en "rumia" y desencanto. $^{108}$

El retrato de Oliver Twist que el fotógrafo le obsequia a la huérfana es también objeto de transformación imaginaria, que no solo apela a la huérfana sino al lector. La fotografía encubre la nada del hasta ahora nombre incógnito y grotesco de la protagonista, quien sorprendida se pregunta “¿Yo soy este?”, a partir de lo cual el fotógrafo la bautiza ya como “Oliverio” (Somers 90).

\footnotetext{
107 "Primer plano de la que trae la comida: temblando, y con un balde vacío en la mano. Ahora un primer plano de la que vigila: se le incendian los ojos hacia mí, y luego me da el traste. Última imagen llena: traste en movimiento acompasado en mi dirección. Vuelven las dos criaturas a su tamaño natural, hablan entre sí y miran el grifo. La que me da de comer se deja, de pronto, llevar por la otra que cocina. Oigo a continuación caer agua en el recipiente..." (Somers 108).

${ }^{108}$ La huérfana se consigue tirado en la basura un libro con múltiples recetas de bizcochuelo, algo que parece delicioso y ella nunca ha probado, entonces decide imaginarlo: "En adelante, cada pedazo de miserable pan que comiera sería mi manjar. Hasta que un día, por obra y gracia de la continuidad, llegase a saborear las setenta y siete fórmulas. Quedaba solo el arte de tomarlo de un modo especial, con la palma de la mano hacia arriba como en bandeja, no fuera a desmigajarse" (50).
} 
La inclusión de la fotografía en el texto de la novela como parte de la historia personal de la huérfana, así como en la portada original de su publicación, es una llamada por partida doble. En el personaje, la foto, tal y como reacciona ante ella, es una reiteración o eco de la pregunta irónica que está en juego: ¿qué sabemos realmente de quiénes somos? Una imagen distorsionada, simbólica, que alega ser nuestro "retrato" verídico, no obstante estar radicalmente separada del cuerpo y del alma. Y en lector, por su parte, la fotografía de la portada acompañada del título "seducen" e intrigan, y le dan una imagen a cambio de lo que permanece innombrado a lo largo del relato.

El carácter liminal del personaje de la huérfana al entroncarse con la imagen de Oliver Twist impresa en el libro, que el fotógrafo emula con el sombrero masculino que le "encasqueta" a la niña y una cinta negra "en forma de moña bajo cuello de la blusa", resulta excesivo en términos de los límites entre la realidad y la ficción (Somers 89). La huérfana, que como tal ya es una figura existencial, una manifestación espectral y metamórfica, ahora no solo ocupa un lugar textualmente marginal, sino metacaracterizado, en tanto personaje de ficción creado por otro personaje de ficción (el fotógrafo) que, a su vez, remite a otra figura ficcional (Twist).

De nuevo, esta multiplicidad conduce lo demoníaco, a la diversidad de perspectivas —en este caso, máscaras — que caracterizan a lo diabólico, y que tiene implicaciones en la crítica que hace Somers de la sociedad postmoderna. Pues, mientras estos caracteres continuamente parodiados en el texto, ya por contraste o por desdoblamiento (dobles sugeridos, también incongruentes), abogan por encontrar una autodeterminación de su existencia indeterminada, liminal y marginal en sí, están flotando entre el pasado y el presente, la realidad y la imaginación, la vida y la muerte 
simbólicas. Son, de alguna manera, un espejo de la memoria, que es igualmente un espacio limítrofe entre la realidad y la ficción. La exploración de Somers de personajes tan liminales en esta novela puede comprenderse como un propósito de reflejar el carácter de inexistencia y deshumanización de los huérfanos, los perseguidos, los marginalizados de toda la sociedad occidental.

Por otra parte, desde el punto de vista de la relación de la literatura con la vida, ¿cómo se explica que sea necesario recurrir a la figura de Oliver Twist para describir a una huérfana cualquiera, que el estado de abandono e incertidumbre de una niña tenga una fuerza más convincente si se la califica de Olivero? Que la vida imita al arte, como supone el fotógrafo y asiente el loro, y no lo contrario, pareciera apuntar a que hay una literatura de la que la vida no puede prescindir, una complicidad entre lo ficticio y lo real, que no sabemos con precisión de qué está compuesta ni a quién beneficia más. De un lado lo imaginario es solamente lo "representado", del otro, reivindica su capacidad de trascendencia, de inmutabilidad.

De acuerdo con Beatriz Vegh, ni el rumiar de la niña ni el registro del loro procuran narrativamente la inscripción del misterio, el horror y la situación liminal de Un retrato... (la violación, la muerte, la supervivencia) (229). Si bien la postmodernidad se allega más a la comedia humana que al malestar abisal, como apunta Kristeva, la multiplicidad de perspectivas oscuras, la obsesión con el terror sublime y la subjetividad, los personajes monstruosos, las preocupaciones prometeicas y las diversas aproximaciones narrativas, dan asimismo cuenta de una postmodernidad de naturaleza profundamente gótica (212). De igual forma, Un retrato... se apoya en el presupuesto expresionista cuando no pone sus esperanzas en el intento de elevar la realidad al plano 
de la reconciliación con ideales prefigurados (social, religioso, literario, etc.). De allí que sea lo sublime gótico y no lo sublime convencional lo que caracterice la experiencia de la huérfana, pues no aspira a lo divino ni a lo sagrado, en tanto que como en el expresionismo, no hay tal valor trascendente con qué reconciliarse, sino un orden social a ser purgado y un conjunto de imperativos éticos por esclarecer (Murphy 153). 


\section{Capítulo 5. De la elegía gótica al "teleteatro": amor, muerte y postmodernidad en "Viaje al corazón del día. Elegía para un amor secreto" (1986)}

Cuando Armonía Somers revela la existencia de esta nueva novela tras diez años de silencio la noticia causó no poca perplejidad. De manera insospechada, se publican en el año 1986 conjuntamente dos obras, entre ellas, la más esperada y desde mucho antes anunciada Solo los elefantes encuentran mandrágora, novela cumbre con que Somers pretendía cerrar el ciclo de su narrativa. Viaje al corazón del día produjo entonces profunda extrañeza, no sólo por su inesperada aparición, sino porque en palabras de la autora esta novela representaba para ella el verdadero "vuelco" de su escritura (Campodónico 242). El insólito "individualismo romántico" del relato y su concomitante locus provincial, ubicado entre la Suramérica de finales del siglo XIX y la Europa decimonónica, fueron incluso objeto de intriga para la misma Somers, quién significativamente se cuestionaba: “¿Por qué una ambientación de fines del siglo pasado cuando pisamos los umbrales del siglo XXI? (...) ¿Por qué la guerra franco-prusiana de 1870 a que me llevó otro personaje como si me arrastrara por los cabellos?” (Moraña 189; Campodónico 244).

Confluencia de géneros literarios

Escrita en primera persona, Viaje... hace eco del testimonio con "olor a calabozo" que le precede en Un retrato..., esta vez desde el silencio de una capilla, donde la protagonista reconstruye "la historia más siniestra, intensa y delicada" de su vida y de los personajes que configuran su mundo (Somers 14). Los elementos epistolares, inscritos a 
partir del título ("Elegía para un amor secreto"), anticipan el corte funesto de este relato, vinculado con el romanticismo. ${ }^{109}$ Sin embargo, como en la mayoría de sus estrategias narrativas, Somers retoma esta orientación con fines deconstructivos. Rómulo Cosse, en su ensayo "De La mujer desnuda a Sólo los elefantes encuentran mandrágora o el monstruoso esplendor del relato", advierte cómo en algunos fragmentos de Viaje... existe el cruce o "tensión, entre la recuperación cultural de dicho modelo y su visión desacralizada" (202). Cosse se refiere a "tramos de la historia que retoman precisamente el canon romántico" junto a los cuales "se insertan otros que lo contradicen" (202). Esta visión se concentra en la parodia del estilo folletinesco como factor que procura la distancia crítica necesaria de este "pensamiento" o "modo social de ver" mediante el cual "se produce la ironía crítica" (Cosse 203). La dualidad o contradicción que Cosse observa en la deconstrucción del lenguaje folletinesco coincide con las reflexiones de Iber Verdugo, para quien la novela Viaje... requiere una "doble lectura" en lo que parece una continua exposición de una "realidad falsa" pretendiendo sustituir a la "real" (185).

Hay, pues, una parodia del lenguaje folletinesco que deja en claro "que Somers desacraliza tanto las técnicas particulares como la visión romántica", mas no para catapultar este romanticismo en un compartimento desusado y sin sentido, sino para extraer un significado más profundo. Carina Blixen tiene una postura relevante al respecto. Según ella, es evidente que la estructura episódica, lineal y simple que "muy bien puede cumplir los requisitos de la entrega folletinesca" no refleja el realismo social propio del género y su voluntad de denuncia, sino que se emplea en virtud de acentuar "el desafuero de los sentimientos" (Blixen 202-5).

${ }^{109}$ En conversaciones con Campodónico, Somers acuña a Viaje... como "una pequeña novela romántica" (243). 
El subgénero de folletín, recurrente en las novelas de Somers, asume aquí, pues, un rol distinto, ya que si la historia sigue las directrices del Bildungsroman, tomando prestados elementos del romance de forma palmaria, este aparece filtrado por la autoconciencia crítica y, a ratos, irónica de la protagonista, siempre con la intención de “desatar lo escandalosamente emocional" (203-4). En este sentido, podría decirse que la “magistral (...) manipulación” o parodia del folletín de Viaje... concuerda con el melodrama expresionista de vanguardia, modo literario bien conocido por la autora, y que ella misma admite haber tomado en cuenta en la escritura de esta nouvelle (Blixen 203). ${ }^{110}$

Dada la naturaleza mixta del melodrama, es fácil comprender por qué la intriga, el suspenso y la creación de personajes y ambientes exóticos se atribuyen al género del folletín, como apunta Blixen en relación con Viaje..., ya que estos rasgos forman parte de su amplio campo de acción (203). ${ }^{111}$ Desde el punto de vista de este estudio, dichos aspectos, sin embargo, unidos a la marcada emocionalidad, conducen ineludiblemente a establecer una relación entre el carácter melodramático de la novela y el modo gótico literario por la articulación de una experiencia cuya "intensidad" emocional es deliberadamente excesiva. La estética gótica, recordemos, se define por tratar de transmitir una experiencia "totalizadora", una emoción "única, atemporal, e inconmensurable" (Beville, Gothic-postmodernism 27). Llama la atención que hasta ahora no se haya trazado líneas de sentido entre estos géneros patentes en Viaje..., más

\footnotetext{
110 "La nouvelle podría servir para un teleteatro, lo reconozco, pero no sin trabajo cuidé el no caer en lo cursi como un peligro inmanente, lo que creo haber logrado" (Campodónico 242).

${ }^{111}$ Marcie Frank explica que uno de los aspectos del melodrama es su "joint status as both genre and mode. In its capacity to spawn multiple adaptations across different media, including novels, plays, operas, print series, comics, films, television, and videogames, melodrama provides an early instance of intermediality (...) among media" (540).
} 
aún a sabiendas de que el melodrama y el gótico trabajan juntos desde los inicios del romanticismo, ${ }^{112}$ época histórica que la novela saca a la luz. Paralelamente, el desdoblamiento de los personajes, la referencia continua a un paisaje remoto de un tiempo pasado y presente simultáneos, el motivo de la clausura, la repetición, la evasión imaginativa, rasgos todos subordinados al tópico de la muerte, trasuntan el modo gótico que, además de compartir estas mismas características con el melodrama, está en la raíz elegíaca del relato, claramente manifiesta en la novela. ${ }^{113}$ Cómo se articulan la elegía gótica, el folletín y el melodrama expresionista de vanguardia en Viaje..., qué aspectos del romance y del romanticismo la novela retoma y reinventa en términos de la concepción del amor y la muerte en la postmodernidad, son las cuestiones que aborda este ensayo.

\section{La historia y su reflejo}

En el prólogo de Viaje... se nos advierte explícitamente que estamos en el umbral de una historia gótica, pues se le avisa al lector que se le conducirá por un "sueño de horror" y se preludia con detalle el origen misterioso del relato que se va a contar (Somers 9). El breve fragmento, firmado con las siglas L.K.H (Laura Kadisha Hassan), introduce la primera parte parte de la novela, divida en seis apartados con números romanos, seguidos de cinco cartas que llevan por título el nombre del destinatario, todos

\footnotetext{
${ }^{112}$ David Punter en su ensayo sobre "Gothic and Romantic" apunta la profunda influencia de la literatura de Schiller y de los escritores góticos germanos, autores románticos por excelencia, en el gótico inglés, particularmente la obra Die Räuber (1777-80), que combina el gótico y las descripciones melodramáticas (p.16).

${ }^{113}$ Jerrold E. Hogle, en su ensayo "Elegy and the Gothic: The Common Grounds", desarrolla ampliamente los aspectos que hermanan a ambos géneros, algunos de los cuales mencionaremos aquí en el siguiente apartado.
} 
personajes de la historia o de la vida de Laura. El último apartado de esta serie lleva el mismo nombre de la protagonista y tiene como subtítulo "El viaje nocturno", un breve relato que concluye la sucesión de la historia retrospectiva con el viaje final de los amantes y el suceso de la muerte de Laurent. Todos los apartados así como las cartas dirigidas a los personajes pueden considerarse en su conjunto como un relato autobiográfico de Laura, lo mismo que "Los papeles del adiós", escritos por Hildegard en la segunda parte, concentran en buena medida la historia de su propia vida antes de conocer a Laura. Se trata de dos relatos autobiográficos distintos, no obstante conectados entre sí por una vivencia en común: la estadía en la casa de campo Las Nubes, lugar en que Hildegard enseña a tocar el piano a Laura durante varios años.

Ahora bien, la continuidad entre ambas partes, en principio dada por la información que completa Hildegard de lo ocurrido en la hacienda tras la partida de Laura, no se produce únicamente por vía de la hilaridad anecdótica, sino por lo que nosotros llamaríamos una suerte de reflejo en que una historia "otra" contempla las claves y variantes de un mismo tema, dotando de sentido(s) la historia primera. ${ }^{114}$ Las dos partes que dividen el relato con dos narradores distintos establecen así una interacción cuyo efecto será el de una "relectura", tal se asistiera a un diálogo que el texto emprende "consigo mismo" (Cosse 207).

Podría decirse que este diálogo que mira hacia atrás y habla desde la madurez se opera sobre la base de la elegía gótica, amén de las múltiples características de este modo discursivo que los textos comparten. El punto de inflexión más marcado de esta forma

\footnotetext{
${ }^{114}$ Rómulo Cosse hace la importante salvedad de que "durante los segmentos que cuentan unidades comunes (...), se percibe con más fuerza que nunca, que si la historia es común a ambas, el discurso es particular a cada una", con lo cual puede entenderse que hay un cambio de "mirada" — como él también dice- que permite este enriquecimiento de una perspectiva ampliando o profundizando la anterior (207).
} 
narrativa en los relatos es la lucha interior de ambos personajes por esclarecer su historia y plasmar la experiencia de la muerte, recurriendo a eras históricas y sociedades completas que se hunden en el pasado de forma nostálgica, y que amenazan con extender el "aura de la muerte al presente y al futuro" de sí mismas (Hogle 578). ${ }^{115}$ En este punto, el lector se ve continuamente impelido a completar el sentido entre estos signos que aparecen de forma fragmentaria, en apariencia distantes entre sí, que sin embargo se corresponden con motivaciones de una misma índole. La forma que hermana a estos relatos apunta a rasgos en que la elegía y el neogótico coinciden, y cuyos pasos señalan el desenvolvimiento de un mismo proceso. ${ }^{116}$ Hogle define este desarrollo como el "proceso elegíaco" que el relato de Laura y el de Hildegard parecen seguir, en tanto que sus historias se basan, tal y como él describe este proceso, en "una muerte cuya imagen necesita ser contextualizada" (575).

La historia de Laura comienza significativamente narrando la llegada de Laurent al mundo, su insólito encierro y temprana muerte, manera en que prologa su "extraño y tristísimo relato" (Somers 14). También Hildegard describe desde un principio, de forma más parca y simbólica, imágenes que anuncian un relato de pérdida. ${ }^{117}$ Esta repetición

\footnotetext{
${ }^{115}$ Laura descubre en el urnario familiar las cartas de su tía Encarnación, en que se narran episodios de la guerra civil de ese país suramericano, y que marcaron la moral acusadora del hogar en que le tocó vivir. También, su origen oscuro de razas mezcladas retrotraen las guerras entre moros y cristianos, cruzadas que ella evoca y cuestiona en favor de la propia reconquista de su libertad. Hildegard, por su parte, narra los horrores de la guerra franco-prusiana que enmarcaron su juventud. De forma directa o indirecta, la guerra y la muerte de estas épocas específicas moldean sus historias.

${ }^{116}$ Según Jerrold E. Hogle, la elegía y el gótico persiguen tres objetivos: primero, vaciar los vestigios del pasado, aún persuasivos, que encubre y rodea la muerte; segundo, dotar de sentido ese significante vacío retrospectivamente por medio de la introspección; y, por último, recrear el sentido nuevo, "producto de la tensión entre las formas eternas", amén de reelaborar y dar forma a las creencias anteriormente en conflicto en el personaje (568).

${ }^{117}$ Hildegard recuerda los hábitos de Las Nubes, la casa de campo donde ambas vivieron, "Un ave sin plumas. El ave despojada, qué tristeza. También el cordero sin vellón”. En el siguiente apartado, titulado en
} 
temática con sus variaciones se hace más evidente cuando los símbolos que marcan la experiencia de Laura no solo se reiteran en el de Hildegard, sino que parecen encontrar su raíz en esta otra vida, configurando una especie de mise en abîme gótico que opera en distintos planos, y cuya superposición de remite a un mismo proceso elegíaco, no obstante tratarse de dos historias distintas (Hogle 578).

En este sentido, la relación especial que destaca Cosse entre Laura y Hildegard resulta crucial, pues del vínculo entre ambas deviene, asimismo, una concepción plural de la novela, cuyas partes el lector difícilmente puede deslindar ni mucho menos colocar en un orden jerárquico, cual si una historia estuviera subordinada a la otra. ${ }^{118}$ Ciertamente, Hildegard ahonda en esta afinidad llevándola al plano de la historia, como una llamada a la reflexión de la novela sobre sí misma: "Quién lleva a quién. Tú o yo. Eso nunca se sabe en viaje de dos" (Somers 110). Y Laura, en su ejercicio de compiladora, incluye el relato de Hildegard en el suyo deliberadamente. ${ }^{119}$

Desde el punto de vista gótico, Laura y Hildegard aparecen como dobles de sí mismas, Doppelgänger "parasitarios" de un mismo "roble" o naturaleza, tal y como señalan las narradoras. ${ }^{120}$ La representación del doble no se alía en este caso, como en

su español alemanizado "De ese mañana" (“de esa mañana") reseña la mañana en que su padre, temiendo ya la invasión y el ataque de los franceses, decía que había que "matarlos en su propio idioma. Entonces: je meurs, tu meurs, vous mourez. Ils meurent!", clara alusión a una muerte que ya se siente como propia y con que inicia el recuento de su vida (Somers 111).

${ }^{118}$ Cosse resalta el particular "binarismo" que existe entre Laura y Hildegard, en que se acentúa la identidad parcial de las dos figuras frente al resto de los personajes femeninos (207).

${ }^{119}$ Uno de los objetivos que se plantea Laura con sus escritos es componer la "gran historia de Las Nubes", la casa de campo que sirvió de escenario para tantas historias, suyas y ajenas, con ayuda de "extraños seres relatores por nacimiento que saben ordenar los datos, llenar lagunas a fuerza de imaginación (...)". Más tarde, en los papeles de Hildegard, aparece una nota al pie de estos "seres" corroborando la identidad de una figura que menciona Hildegard solo de nombre (Somers 87, 131).

120 "Fräulein Hilde y yo (...) como verdaderos muérdagos parasitarios de aquel inmenso roble", escribe 
tantas ficciones góticas, con la figura de la bestia ni con la del monstruo, sino con la calidad etérea y fantasmal del otro. Fräulein Hildegard llama a la niña "Laura Melodie" y Laura firma su carta a Hildegard con el nombre de Melodie. Claramente el conjunto de referentes plantea la analogía entre la presencia y lo espectral, de lo que se siente y no se ve, un motivo que Somers toma del gótico para sugerir, más que un aspecto sobrenatural, una cualidad o estado psicológico común a los personajes. Esta insistencia en lo fantasmático- musical superponiéndose a lo concreto apela sin duda a un vínculo espiritual entre ambas, seres marginales, al fin, en la "tétrica casa" de campo, y constituye el leitmotiv del proceso elegíaco de la novela, íntimamente asociado con la muerte simbólica y la experiencia de lo sublime y lo monstruoso. ${ }^{121}$

Hildegard, como ente predestinado que percibe Laura en ella, ${ }^{122}$ aparece en su vida como una fuente de resguardo. Antes, el tiempo "no tenía variaciones, sólo los demás vivían, morían, se emparejaban a fin de volver a empezar el ciclo”. Cuando llega Hildegard el tiempo empieza a recobrar su sentido: "El pequeño reloj marcaba las doce del día. Así empezó nuestra componenda amorosa con Wolfgang Amadeus sobre las bases de una palabra que cambiaba mi nombre. Yo parecía estar destinada a eso" (37, 45). La noticia de la profesora de piano recién contratada se asume como premio o compensación: "Algo tendría que suceder a mi favor entre tanta desgracia", como si

Laura. Y Hildegard bautiza a Laura con su nombre real, que no descubre sino al final en sus manuscritos, "Melodie" (Somers 53, 144).

121 "Varias vidas en cada vida, Y varias muertes", escribe Hildegard. Mientras que Laura se describe en los primeros años de su vida como "un espectro triste" $(112,28)$.

122 "la enviada llegó en cierta luz primaveral con un gran pájaro azul en el sombrero (...) tan sobria en lo demás que hubiera parecido un hombre (...). tomó mis manos, las exploró de ambos lados, midió mis dedos con los suyos, los flexionó, dejó caer mis muñecas varias veces y dijo simplemente con su acento inconfundible: no sólo Laura, sí, Laura Melodie, Melodie, ja,ja” (44-5). 
Hildegard, en su rol de doble, viniera aquí a hacer las veces de "ángel guardián”, un tropo gótico recurrente en la imaginería del Doppelgänger (Beville, Otherness 49). De manera llamativa, la profesora representa una figura y medio de auto-preservación en términos de protección ante la muerte y la destrucción de "la hacienda del miedo", no obstante ser, al mismo tiempo, la mensajera de la muerte (58). En efecto, así como ambas luchan por conquistar y mantener la música interior que Hildegard denominó "Ferne" (lejanía) o nostalgia por los orígenes inciertos, así también Hildegard inicia a Laura en el duelo, la prepara con un espejo y un velo negro para cuando sea el momento de usarlo $(55) .{ }^{123}$

Cada referencia que las reúne es una alusión constante no a objetos, sino a otros símbolos que remiten a su vez a figuraciones de la muerte. Esto ocurre también con la imagen del caballo, la yegua "Borah" de Laura y el viejo recuerdo de Zauberei de la infancia de Hildegard, la Araucaria y el eco de los pinos de la Selva Negra $(41,115,142)$. De alguna manera Hildegard inicia a Laura en el significado de estas imágenes, imágenes de pérdida para Hildegard, que ahora, proyectadas en Laura, re-cobran el sentido, una duplicidad típica del estado mental de las figuras del gótico (Hogle 580). Semejante psiquismo está profundamente vinculado a la elegía, una vez que estas primeras impresiones "murientes" o estado moribundo acusan una muerte continua (581). Esta muerte simbólica en que ambos personajes se encuentran confiere el tono o emoción elegíaca más sobresaliente al texto en su totalidad, que es la melancolía, estado también más característico de los personajes góticos.

\footnotetext{
123 "Por la sangre de cada cual anda una Ferne diferente, porque procedemos de seres y lugares insospechados por nosotros mismos: tu lejanía es con flauta, la mía con el sonido de un cuerno de caza" (48).
} 
La melancolía, en los términos duales de Hildegard, protectora de la muerte y promotora de ella, puede significar aquí la reacción al cambio a que más ha instado el gótico desde sus orígenes: la necesidad de dotar de un sentido nuevo las creencias y los esquemas de pensamiento pasados que aún merodean la conciencia del individuo, su cultura y percepción de la muerte. La música interior que Hildegard y Laura escuchan, que acerca sus "vidas lanzadas una a la otra desde inmensas lejanías", en una "especie de lamento con un leitmotiv más que triste", corresponde a un oxímoron relevante en relación con el significado que la melancolía y la música de Mozart tiene para ellas (Somers 48). Hildegard comenta en sus memorias: “Como (...) Wolfgang Amadeus (...). Soy la mosca en la tela. Pero también la reina decapitada que vuelve al salón” (128).

En términos góticos, lo que encontramos aquí es la figura de la muerte volviendo a la vida: "un acompañante sin cuerpo", como la profesora misma se define, y cuyo estado claramente refleja los terrores primitivos que continúan existiendo en la profundidad de su conciencia, aun cuando estos han desaparecido del mundo que la rodea (la guerra, los padres muertos, la hacienda abandonada). Laura se identifica con Mozart y acto seguido propone la asociación de "la sonoridad como obsesión convocando a una especie de concierto dislocado", remitiendo a la misma condición de terror y oscuridad que la acecha de continuo, como alguien "Mitad cristiana, mitad musulmana. Que no sabe quién es" (141).

Es evidente que en las metáforas asociadas a Mozart o a lo musical en sí se problematiza la existencia, y lo que en la niña se sugiere, en la profesora de piano se manifiesta. Se trata de vida y muerte continuas, no sin mutilaciones, como parte de un mismo proceso vital, vida como "proceso elegíaco". Así lo demuestra Laura cuando 
atribuye significativamente a su "formación epistolar" su capacidad de "mantener correspondencia con el doble etérico de alguien", y escribe: "Por eso es que largo así al aire estos papeles: 'A Fräulein Hildegard, dondequiera que esté'”. Hildegard, por su parte, escribe sus manuscritos a Laura y decide dejarlos en Las Nubes, pues la gente siempre retorna a los lugares "de algún modo", y añade: "Yo jamás de cuerpo presente" (Somers 77, 109). La cadena de símbolos música-Ferne-Mozart que distinguen el estado melancólico que une a las protagonistas, remite entonces a una forma espectral de estar en el mundo que transgrede los límites ontológicos, una vez que le permite a Laura y a Hildegard estar presentes sin estarlo.

La "espectralización del otro" y el mito del romance

Muy posiblemente, este carácter espectral o tipo de sensibilidad "espiritual", que reúne a los personajes de Laura y Hildegard, es lo que llevó a los críticos y a la misma Somers a concebir la novela como una historia de corte romántico. ${ }^{124}$ Las consideraciones de Terry Castle sobre este cambio de percepción, parecen ofrecer una aproximación acertada en relación con los personajes. Castle advierte que no se trata tanto del poder de la emoción sola lo que proyecta una nueva sensibilidad, sino el hecho de que se tiende cada vez más a enfantasmar la percepción del otro, a otorgarle un sentido espiritual tal al individuo, que su ser se torna en un mero "efecto mental o imagen, como si estuviera de hecho en el plano de la misma conciencia”, esto es, presente

\footnotetext{
${ }^{124}$ Uno de los aspectos revolucionaros de la ficción gótica en la cultura europea fue su forma de articular una nueva percepción de la experiencia humana. El nuevo poder de la emoción, que juega un rol paradigmático desde entonces hasta el gótico de nuestros días, prefiguró así la "fabricación de la sensibilidad romántica": una forma de sentir desconocida, un modelo de relaciones humanas y fenomenología del sí mismo y del otro radicalmente distinto. A esta concepción los críticos la calificaron de "romanticismo individualista", el mismo término que utiliza Moraña y Cosse al referirse a Viaje... (Castle 125).
} 
en todo momento, independientemente de que esté físicamente o no allí (125). En Viaje..., este fenómeno de la "espectralización del otro" u "obsesión nueva con imágenes internalizadas de los otros", se combina con elementos del romance y se manifiesta de diversas formas (Castle 125).

Cuando repasamos las distintas fases del romance o del "mythos del Verano" en el estudio de Northrop Frye, la percepción fantasmática señalada atrás se aviene perfectamente con la mirada nostálgica y la intención gótica de buscar siempre “alimentarse de nuevas esperanzas y deseos" impresa en el romance (Frye 246). Tanto en la historia de Laura como la de Hildegard aparece esta perenne nostalgia casi infantil en que la afectividad se construye sobre la base de la memoria, una memoria que en Viaje..., no obstante, asume la forma de fantasmas.

La motivación de Laura al escribir una larga carta al Padre Artemio, seguida de las cartas que dirige a su tía Encarnación, a Refugio y a Hildegard, es comunicarles sobre el suceso de la muerte de Laurent, cuya presencia desde el principio y a lo largo del relato es fundamentalmente fantasmal: "Laurent se hallaba (...) condenado a muerte a pesar de no haber nacido nunca", él era una "rara avis in terris, el hombre que no nació y sin embargo vive" (Somers 59, 82). También Hildegard, al narrar su aventura amorosa con Rudy, más allá de querer plasmar un fragmento esencial de su vida, busca apartar el mal, "la mudez", ante las "tristes voces de ultratumba" que la "persiguen" (123). La motivación de la "búsqueda" o aventura en ambos personajes tendría que ver con esta necesidad de confrontar la muerte o las sucesivas muertes, hasta ahora calladas en la conciencia, que culmina en una anagnórisis amorosa (descubrimiento y muerte del 
héroe), y en el reconocimiento, asimismo, del misterio de la identidad, la subjetividad y los orígenes del lenguaje.

La trama de la historia de amor de Laura y Laurent se equipara con la secuencia y procesión del romance en los términos de Frye con ciertas alteraciones. ${ }^{125}$ En Viaje..., héroe y heroína se confunden, y a menudo comparten papeles de un mismo rol. Somers ha reproducido así el surgimiento de dos dobles que forman una trinidad con la protagonista Laura: Laurent y Hildegard. En la historia, es Laurent, sin embargo, el personaje que más se acerca al mito, tal y como Laura observa, y quien despliega en mayor grado atributos de la divinidad. ${ }^{126}$ La primera vez que Laura ve a Laurent "tenía la misma oblicuidad del de la Anunciación de Fray Angélico, era como una voluntad dirigida desde el cielo hacia algo que está sucediendo en plena tierra (...) porque allí se haya lo que el sol ha visto, no lo que ven quienes miran el sol" (17). Como en el romance cabal, Laurent posee cualidades primaverales: se asocia con el alba, el orden, la fecundidad, el vigor y la juventud (Frye 247). ${ }^{127}$

Todo el conflicto en el relato, al igual que en el romance, se caracteriza por el movimiento constante de la naturaleza, por lo que no sorprende, que "las imágenes cíclicas tienden a estar presentes y las imágenes solares descuellan normalmente entre las imágenes cíclicas" (Frye 247-8). El solo título de la novela llama nuestra atención hacia

\footnotetext{
${ }^{125}$ El romance tiene tres etapas fundamentales: la etapa del viaje peligroso y de las aventuras menores preliminares (el agon o conflicto); el combate decisivo (pathos o combate mortal), y, por último, la anagnórisis o el descubrimiento, donde ocurre la muerte del héroe, su resurrección o renacimiento (246-7).

126 “El niño que nadie había visto (...) era ya para mí lo que hoy es un mito, algo cuyas raíces se ignoran”, "ambos retornábamos al sol, reinventábamos el mito de aquel sol que él había visto antes (...) el cual era el mismo desde el origen de las creencias, aunque yo no lo supiera todavía” (Somers 14, 21).

127 “[E]l muchacho bello como un Adonis”, "El sumergido. El recobrado (...) El abandonado (...), y un aire de no ser él de este mundo", "como si él mismo fuera la Divinidad", "tal un antiguo dios de oro (...) con la elegancia de un delfín"; Laurent el "solario" (14, 64, 84, 106, 95).
} 
el paisaje y el clima, hacia un espacio cálido en que se ocultan pasiones que no se corresponden con perspectivas convencionales (Viaje al corazón del día). Somers utiliza este antecedente para crear un contraste inmediato con un espacio al que se dedica mucho más: la "tétrica casa" de campo, Las Nubes, espacio espectral también en un sentido antitético, en tanto que se concibe como un lugar insustancial donde se vive "la irrealidad de lo real" (Somers 27).

Análogamente, así como Laurent es similar al mítico mesías, que proviene de un mundo superior, así los poderes de su contrincante se asocian con un mundo inferior. Es el caso del personaje de la tía Encarnación, responsable de su ocultamiento al nacer y del destierro de Laura a Las Nubes. Una mujer "tan bella de rostro (...) y al mismo tiempo tan severa", "así de fuerte como el mismo Dios", que "no había sido solo eso, una potestad transmisora del terror al juicio final, tenía también su gracejo muy de este mundo, y a veces lo empleaba con la gente ignara que estaba bajo su férula sin dar explicaciones" $(16,35,59)$. Mientras más atributos de divinidad adquiere Laurent y, en consecuencia, Laura, más cualidades míticas demoníacas asume Encarnación. Por eso no extraña cuando se le asimila al tipo de la "madre terrible", cercana al incesto, tal como Medusa, con una tendencia de perversión erótica (Frye 258). ${ }^{128}$

Aún después de su muerte, la imagen de la tía continúa siendo una presencia siniestra, tanto que, de vuelta a la mansión, Laura advierte la atmósfera pesadillezca a la que se aproxima: "influida por años de Encarnación y sus futuros amenazantes, di de pronto en imaginar que adonde me llevaban era al infierno" (60). En este punto, el

\footnotetext{
${ }^{128}$ Laurent confiesa la idolatría de la tía: "me dijo que yo era un retrato que ella había hecho del Capitán Belleau, pero poniendo más cuidado que Dios", "Y a continuación me besó como nunca, casi ahogándome" (75).
} 
romance se expresa con mayor claridad cuando Laura atraviesa por una "muerte ritual", siendo la casa de su primera infancia el lugar de las "formas fijas", del "infierno inmóvil" donde Laurent permanecía encarcelado en el sótano (Frye 247). Es entonces cuando Laura, antes de descender las escaleras que conducen al lugar subterráneo, viste el velo de Hildegard, que ya le había preconizado el suceso (Somers 63). ${ }^{129}$

Todo el trayecto que conduce al sótano de Laurent puede asimilarse a un rito de iniciación en la muerte: “Avanzar hacia un secreto era algo que requería la ingravidez apenas si quebrantada por el peso de mi delgado cuerpo, y asimismo el silencio", "vericuetos que aparecían de sorpresa (...) en la plena oscuridad”, "Y luego lo demás, el sacramental sigilo transmitido por mi antecesora para maniobrar en la entrada secreta (...) con el cerrojo vedado hacia adentro, (...) el instalarse en la otra conciencia que acabaría de percibirlo como si saltara el sello de su eventual sepulcro" (63). Este descenso, que suele asociarse con la figura masculina o el héroe que acude en nuestra ayuda, (Teseo), se ve aquí reemplazado por la de Laura, una inversión protagónica del mito del romance original, así como del gótico temprano, donde la heroína es quien aguarda por el rescate. Pero, además, y lo más relevante aquí, es que el amor en la novela se vuelve en sí mismo espectral, cuando la unión se concibe entonces como una tanatología: "desde que me has amado sé lo que es morir, yo he muerto en ti y de ti esta noche mortal, y quisiera seguir siempre muriendo. No me dejes ya vivir sin morir así todos los días que nos queden" (69).

\footnotetext{
${ }^{129}$ Hildegard "retornó con un delicado manto de encaje negro (...) me envolvió la cabeza con un extremo, pasando el resto sobre mi nariz (...) de modo que sólo mis ojos quedaran visibles. (...) Por un momento creí que recién naciera o volviera desde algo, desde alguien que estaba fuera de mí, pero que al mismo tiempo era yo misma. Y aquello parecía que iba a seccionar mi vida en dos mitades diferentes, cuando ella me desanudó el velo y dijo con su acento inconfundible: 'Te regalo el espejo y el velo para tu bolso, el momento de usar las cosas lo decide la vida. (...) Todo es un gran misterio" (54-5).
} 
El viaje de los amantes a la antigua casa de la costa retoma, por un lado, el hilo simbólico que hermana a la pareja —el mar, elemento arquetípico del romance-, al tiempo que afirma el principio de déjà vu que domina las relaciones humanas en Viaje... y la fenomenología de la lectura. Ciertamente, las figuras en este punto de la historia se confunden con la pareja de los tíos difuntos cuando, a manera de diversión, deciden vestir los atuendos de los abuelos, acabando convertidos en "la exacta medida física" del Capitán Belleau y de Encarnación. El juego "herético" implica una metamorfosis real, en tanto que Laura y Laurent afirman estar "instalados en el otro, asumiendo hasta sus más filosas aristas" (93). De forma paródica, Laura se convierte en literal "encarnación" de la tía, lo mismo que Laurent por su belleza termina siendo el verdadero capitán "Belleau".

De nuevo aquí lo espectral absorbe e invade el terreno de lo vivo, relativizando las categorías absolutas de muerte y vida. Este elemento casi fantástico puede verse como una multiplicación típicamente gótica de los dobles en el relato, en donde los seres aparecen como proyecciones o simulaciones de otros, en espejismos más que en seres de carne y hueso. Así, la trasposición de tiempos y de caracteres hace pensar que la transición de lo mental al hecho es posible, cuando las líneas divisorias entre la experiencia subjetiva y la objetiva se borran, y se produce el extraño efecto de la concreción de lo espectral como un fenómeno no solo legítimo sino inherente a la vida.

Siguiendo el mito del romance, Laurent fallece tras un periodo de abundancia e inocencia, donde predominan imágenes nocturnas y otras asociadas con el aspecto femenino o materno de las imágenes sexuales (Frye 263). ${ }^{130}$ La novela, asimismo, se

\footnotetext{
${ }^{130}$ El último relato de Laura, que cuenta el final de la historia de los amantes se titula "El viaje nocturno" y todo el trayecto está marcado por "el carácter nocturno y furtivo" del tiempo. A Laurent Laura lo nombra el "Profeta de las Lunas", y ella a sí misma se llama "Venus" (Somers 96, 108).
} 
apoya en el mito del verano en el reconocimiento final de la satisfacción amorosa, cuando "la identidad deseosa o hallazgo de la libido busca liberarse de la realidad sin que deje de contener esa realidad": "Laura que fue toda la vida el sol de Laurent y desde ahora el mar de Laurent", le declara Laurent a Laura poco antes de morir (Frye 255; Somers 104). No obstante, su presencia no se prolonga en la vida por causa de un renacimiento, como ocurre en el romance clásico, sino por medio de un fenómeno más controversial: la presencia del ausente por la vía de Dios.

En efecto, Laura halla la imagen consoladora de la muerte de Laurent en el ámbito espiritual: "El os avivó y luego os hará morir, y luego os avivará, y luego a él volveréis" (108). Esta idea aparece ya en el epígrafe de la novela, donde se cita un fragmento del Corán, y se repite en el epílogo, cuando Laura le escribe a Hildegard en respuesta a su "Bésame y dame la mano": "Lo hago larga, fuertemente, sabiendo que todo llega a través de Al-ilá...” (145). La pérdida incita a retornar a la fuente de la memoria, "donde lo muerto continúa estando vivo" (Castle 132). Así lo manifiesta Laurent, también, cuando poco antes de morir le propone a Laura la eterna reunión en una idílica proyección futura del pasado: "vuelvo hacia atrás de nuestras vidas y te veo siempre, esa será la fórmula (...) la invertirás y me tendrás, te lo prometo (...) como si nos despidiéramos junto a un tren que no vuelve" (Somers 102).

De esta manera, Laurent plantea la posibilidad de un destino "exitoso": le ha dado a Laura la fórmula de sobrevenir a la muerte por medio del recuerdo y con ello la clave para trascender la muerte: "De la luna hacia allá ha de empezar el otro, el que no acaba" (McHale 230; Somers 72). Mas el carácter póstumo de los escritos señala asimismo una ambigüedad, ya que siendo Laura ella misma Laurent, es, desde luego, también la voz de 
la muerte articulada, de lo que "ya no (...) se es", como agrega Hildegard (Somers 115). ${ }^{131}$ Semejante duplicidad parece remitir al antiguo "topoi de muerte y ficción" en que el discurso adquiere vida para quien lo lee, tal y como el amante pervive en la memoria del amado. ${ }^{132}$ Así lo advierte además Hildegard en sus manuscritos cuando dice que el día que Laura los encuentre, los lea, corrija, llore y ría con ellos, a pesar de estar ausente, sus memorias muy pronto "entran en la vida" (109). Todo lo cual apunta a que lo escrito (como el amor, lo ausente) tiene esta doble calidad de objeto vivo, aunque siempre como una especie de monumento, "una cosa del pasado que carga necesariamente con un aura de muerte cumplida" (109; McHale 230). ${ }^{133}$

El contradiscurso melodramático

De cara a la naturaleza del relato, es evidente que la correlación entre escritura y muerte, como lo ha sido la del tropo amoroso y la ficción desde todos los tiempos, remite al carácter autorreflexivo de la novela, rasgo típico de la literatura postmoderna (McHale 231). Esta preocupación del texto consigo mismo se manifiesta en la relación entre las simulaciones y la realidad, más concretamente, entre el testimonio "real" y la reconstrucción subjetiva de los hechos. De forma audaz, Somers se vale aquí de la

\footnotetext{
131 "Laurent era yo y yo Laurent", "Laurent era mi identidad, pues al no cambiar él yo permanecía en mí que era él mismo. Íbamos en una carrera desigual en el tiempo, pero nadie nos quitaría lo inmutable, el estar uno dentro del otro aunque simulando dualidad", "una Laura-Laurent siempre ausente de la discreción elemental" $(21,45-6)$.

132 "La Gran Pausa mayor [muerte literal] no contiene más muerte, porque del hombre que me amó he heredado la vida que me reste", escribe Laura a Hildegard, y esta última, por su parte, asegura que el tiempo vivido con el padre de Pierre "cinco felices años (...) sirven para una vida entera" $(81,136)$.

${ }^{133}$ Laurent: "en cada pequeñez de estas sin valor hay una marca (...) como un aura. Tú has visto hoy el resplandor y yo el aura de las cosas, estamos de mano a mano, sin pérdidas ni ganancia” (Somers 103).
} 
estructura melodramática para desmontar, desde de la misma imaginería que la domina, la falsedad y la verdad que la trasuntan.

Vista como una forma tradicionalmente cargada de connotaciones peyorativas, el melodrama se asocia con maneras expresivas un tanto primitivas y el empleo de esquemas de polarizaciones obvias, tales como el uso de tipos en lugar de caracteres individualmente delineados en su complejidad psicológica, el despliegue de una retórica inflada o cruda en lugar de emplear formas expresivas más contenidas. No obstante, el expresionismo de vanguardia se vale de las formas excesivas del melodrama no solo para descubrir lo que en el realismo permanece irrepresentado, lo que se ha denominado "la moral oculta", sino para llamar la atención sobre ese contenido como algo irrepresentable (Murphy 152).

En la novela, como señalamos atrás en relación con el romance, encontramos personajes que tienden a ser símbolos representativos o meros tipos. Esto se enfatiza en la nomenclatura que se utiliza en el relato a través de figuras a las que se refiere por significantes fácilmente reconocibles, como por ejemplo "Flora Remedios", la comadrona, o Refugio, igual a un “terrorífico sótano (...) símbolo de negrura, de prohibición", "quizás de la edad del planeta", "telúrica y barbada" (Somers 12, 28, 57). El fuerte contraste entre buenas y malas figuras que subyace en el melodrama remite al conflicto eterno entre las fuerzas del mal y el bien, tópico que entronca con las raíces del expresionismo de vanguardia y del gótico de todos los tiempos. Ahora bien, esta polarización responde a un aspecto esencial del melodrama como una forma expresiva del exceso, expresión de la cual se vale con la intención de atraer a la audiencia hacia una actitud más contemplativa (Murphy 172). 
Un ejemplo de esta caracterización iconográfica en el texto novelesco puede verse en la figura de Juvencio, cuya imagen causa extrañeza por su simplicidad reiterada en el relato. Juvencio "parecía haber nacido con el nombre puesto, ya que año a año nada se producía como fenómeno visible en su ser" (Somers 38). Este personaje, a primera vista plano, niega por lo mismo el acceso a una fácil comprensión, y, no obstante, el texto se esmera en recordárnoslo una y otra vez. Esta insistencia coincide con el presupuesto del melodrama expresionista de llamar nuestra atención hacia las condiciones morales, psicológicas y epistemológicas que operan en el discurso societario general, más que a las del destino particular de un individuo.

Otro caso llamativo de la representación maniqueísta del personaje ocurre con Encarnación. Su imagen de fortaleza y dominio se ampara bajo una red manipulativa de secretos que solo Refugio como “Ojos y Oídos del Rey” puede saber (Somers 27). Inclusive su discurso en el relato se tacha de "melodramático". ${ }^{134}$ Sus cartas revelan el carácter voraz, casi primitivo que la distingue exteriormente: "En cuanto termine unos trabajos (...) iniciaré juicio de enajenación, pues en algunas cosas soy del Antiguo testamento, ojo por ojo, diente por diente, palabra de Encarnación"; "te autorizo a hacer quitar las alambradas del deslinde, en adelante todo pertenecerá a Las Nubes", "nadie va a ventilar esta triste historia", "porque el dinero lo arregla todo si la estirpe así lo requiere" (34-5, 52-3). Sin embargo, es también por medio de su correspondencia que nos enteramos del fracaso de su matrimonio y del sufrimiento que ha padecido con "un bello marido que demostraba querer más a sus amigos que a ella, principalmente si eran

\footnotetext{
134 “'soy la fiera a la que le han arrebatado la inocencia del cachorro, y voy a cultivar mi sed de destruir hasta lo que, pareciendo invulnerable, me salga al paso...' La carta culminaba en tono mayor de melodrama y luego era sepultada por otras" (Somers 32).
} 
franceses como él y ni decir que marinos", palabras subrayadas por la misma Encarnación (30).

La estructura melodramática de la novela se asienta en este doble movimiento de presentar la teatralidad o "montaje" de la realidad, al tiempo de retornar al impulso que yace detrás de la tragedia y de toda esa teatralidad: "presenta los conflictos humanos fundamentales y le da plena libertad al deseo mediante la transgresión abierta a las restricciones sociales y psicológicas (Murphy 147). Podría decirse que en Viaje... esta transgresión melodramática ocurre en distintos planos. Así, mientras en las cartas secretas de Encarnación a Refugio, el desafuero del deseo manipula los esquemas sociales a favor de intereses personales, a esta soberanía titánica o libertad sin límites le sobreviene una transgresión de otro orden, tal vez mayor, en las cartas que escribe Laura, donde la libertad y el deseo no se ajustan ya a las convenciones sociales, sino que pugnan por concebir un tipo de comprensión distinta de los sucesos.

Cuando Laura le escribe a su tía muerta sobre el deceso de Laurent, acaba con la censura de los temas prohibidos, las excusas acomodaticias, colocándose aun a la par de su villanía:

$[\mathrm{P}]$ regunto a título de qué la someto ahora a esta tortura, a este voraz descarnamiento (...). Creo que usted y yo lo violamos todo, (...) que en materia de mujeres no hubo plural, que al fin de cuenta vinimos a ser la sola mujer en el bienentendido de la perfecta unidad, ya que lo suyo y lo mío, (...) fue nuestro impublicable amor, el vino cuyo nombre se ha perdido (...) y queda destinado al paladar de Dios. (75-6)

Este breve fragmento puede considerarse como uno de los momentos del texto en que la convención realista se rompe a favor de la fantasía, sin la cual el significado de lo vivido no podría representarse. El estatus de paridad entre Laura y la tía-madre-esposa de 
Laurent al señalarse como una misma y "sola mujer" inscribe el déficit del realismo y del sistema clásico de representación para mostrar una realidad a todas luces irrepresentable.

El rol que juega Refugio, en este sentido, es también un buen ejemplo del típico encubrimiento melodramático y de la deconstrucción que se da del mismo rol por medio de Laura. Siendo la responsable de leer la correspondencia que llegaba a Las Nubes, Refugio "leía poniéndose un par de anteojos sobre otro, daba a conocer lo comunicable (...) se reservaba el meollo secreto y asunto concluido" (Somers 28). Laura, que descubre los detalles que subyacen a esa realidad, "en búsqueda de señales más esenciales por debajo de las coacciones del mundo cotidiano", y dice de sí misma que "iba a inaugurar otra Refugio más sistemática o con una misión más compleja, engastar cada noticia en el contexto, vaciar aquel depósito de años encontrándole un sentido unitario" (Murphy 149; Somers 29).

Las cartas funcionan entonces como una forma de contra-discurso que, de un lado, revelan los detalles realistas de una situación histórica, local, al tiempo que personal (las cartas de Encarnación), y del otro, confrontan su epistemología convencional "con un discurso alternativo de representación, en el cual lo real se desplaza por su 'otro' oculto" (Murphy 167). Esto resulta significativo cuando observamos cómo en la novela lo cotidiano sirve para reflejar el estado anémico y fragmentario del mundo, a la vez que enfatiza la necesidad de buscar una alternativa que aparece obscurecida normalmente por lo real. En Las Nubes, no había

nunca nada fuera de su hora o su lugar. Las criadas de dudoso color cucaracha con mimetismo de cocina ya levantaron el arsenal de cosas inútiles de la mesa, y así será cada vez, mortal alguno romperá nada con jubiloso estrépito, una piedra que se estrellara contra un vidrio imantaría de cambios a la aburrida atmósfera del siempre así. (46-7) 
Esta situación inamovible, que refleja con mucho la de Laura, sirve asimismo de acicate para recomponer su historia. Laura percibe su vida como un misterio a resolver: “¿Quién era yo, al fin, un ser humano real, un enigma? Estaba en esa operación de esclarecer el acertijo" (28). En este respecto, Verdugo acierta cuando afirma que Laura "necesita descubrir (...) las simulaciones, construir la realidad, ensamblando piezas en sus relaciones, descubriendo los vínculos ocultados", ya que (182). Laura juega un rol de desmantelamiento de versiones contadas a medias para narrar "el horror que se había acumulado allí como en una cueva de alimañas, pero con la virtud de la coherencia para quien la supiera descubrir” (Somers 29). En este orden de ideas, Laura desmitifica el falso melodrama de juego de apariencias por medio del mismo tono melodramático o intensidad que le es propia. ${ }^{135}$

Tal y como sostiene Richard Murphy, la naturaleza de la respuesta melodramática es una una suerte de "histeria literaria" particularmente relevante en su función de contradiscurso normativo (144). Laura da cuenta en el relato de esta desesperación que la motiva a indagar en su identidad cuando se describe a sí misma como un "demonio enloquecido" con "delirio de integración”, como "poseída por el demonio", en "trance hipnótico" $(18-9,23,25)$. En el preludio al relato, la protagonista apunta al carácter melodramático de sus escritos "como un acto desesperado de comunicar la ansiedad asociada a esta ruptura del sistema moral e ideológico, y expresar el deseo de un nuevo orden", cuando escribe, "reordené materiales, hice entrar por vereda al esplendente caos" (Murphy 147, Somers 9).

Esta intensificación emocional que se opera en el texto se muestra en su atención

135 “[E]ra la única persona capaz de mostrar una angustia (...) que rayaba casi en la histeria” (Somers 55). 
a lo ordinario y en el día a día, donde ejerce mayor fuerza sobre el poder de representación, a fin de corporeizar lo inefable y producir un aumento simbólico o resolución marcada del significante. Así, un modo de representación contra-discursivo típico del melodrama que encontramos en Viaje..., embargado de manierismos exagerados y códigos enfáticos, es el mise-en-escéne y el cuadro. Laura describe los pequeños cuadros que dejaba entrar por la ventana del sótano de Laurent, única forma de “enseñar al preso a leer”, donde el conflicto se dramatiza de forma metonímica, creando una proyección psicológica o simbólica de la historia:

Tomé con ese fin un cartón de menor tamaño que el boquete y escribí sin más: Yo Laura, tú Laurent, dibujando un varón y una niña a cada lado de los nombres, él vestido con lo primero que se me ocurrió, un traje marinero, ella con las gruesas trenzas negras que la caracterizaban. Até el mensaje a la punta de un largo palo y lo bajé. Esperé suspendiendo el aliento (...). Volví entonces a levantarlo y no estaba ya el cartón. Aquello fue una mezcla extraña de alegría y frustración, algo para descifrar sin más ayuda que un corazón decidido a todo, incluso a meterse él mismo por el agujero y decir aquí estoy, tómame, juega conmigo, devórame si ese es tu gusto. (Somers 20)

Los carteles ofrecen una imagen visual simbólica de lo inefable y del significado inexpresable, como única forma de comunicación en circunstancias de clandestinidad y peligro. Luego, estos adquieren un carácter todavía más específico cuando Laurent de hecho aprende a escribir, y a la breve sentencia de Laura "Sol que es Laurent", Laurent responde "Laura Sol Laurent", con lo que dichos cuadros instauran la unión mítica de la pareja.

Simultáneamente, los mensajes apuntan a cuestiones que desplazan "la atención hacia asuntos metafísicos más amplios que exceden el ámbito del drama humano de lo real" (Murphy 149). Tal es al menos la impresión que tenemos cuando luego de que 
Laura colgara la frase "Laura ama a Laurent", Laurent le devuelve el cartón preguntando "qué es ama" (22). Es evidente que estos cuadritos no pueden leerse únicamente en relación con la trama, ya que al tiempo de afectar la narrativa, sugieren por igual una intensificación de sentido o exceso de significado que trasciende la narrativa, y plantea la cuestión en términos ontológicos más amplios, interpelando al lector directamente.

A la hora de interpretar el aspecto espiritual o esencia que trasunta estas escenas, el lector bien puede ampararse en la tradición simbólica, y no obstante, la exageración melodramática y la deliberada tenebrosidad de la composición lo conducen a un tipo de lectura que rechaza la solución simple y convencional. En este respecto se refleja precisamente el tortuoso camino que ha escogido la protagonista, quien fuerza de alguna manera a la audiencia también a continuar la búsqueda por una alternativa de sentido ante lo que aparece como inexpresable.

Novela y realidad

El melodrama expresionista insiste primordialmente en el ámbito de lo inefable dentro del campo vital en que priva la desaparición de los valores espirituales y, por ende, de lo que yace inarticulado o marginalizado en el área de la experiencia. Como en la literatura fantástica o gótica, puede decirse que el melodrama expresionista se adapta a un tipo de representación cuya manifestación no sería posible por la vía estrictamente convencional del realismo. De ahí su tendencia al exceso, al anti-ilusionismo y a la autodesestabilización que emplea mediante la "abstracción” (los cuadros-carteles) y la "duplicidad" (personajes que funcionan como dobles de otros, complementarios o 
contrarios a sí mismos), aspectos que indican su pronunciada auto-reflexividad y autoconciencia (Murphy 154).

La historia de Laurent o Macario, hijo de Eulalia y apartado de ella para evitar el escándalo de un embarazo fuera del matrimonio, sirve de escenario inicial para mostrar la desacralización de los valores en un mundo donde impera el engaño, la impunidad y el abuso de los inocentes. Al emular en estilo y estructura el género de folletín o melodrama del siglo XIX, e incluso, tomar por tema la guerra franco-prusiana y los complejos culturales de la Hispanoamérica de entonces, Somers apela no solo al proceso de imitación, como señala Blixen, sino al de la repetición, rasgo frecuente del gótico (205). En este sentido, la novela admite la repetición como rasgo intrínseco a la escritura, bien si pensamos en términos de la relación entre la representación y el original ausente, o bien si consideramos que los efectos poéticos, como advierte Punter, descansan en variantes de representación en virtud de sus efectos (284).

La repetición en Viaje... se da de distintas formas, siendo tal vez la más obvia la reiteración de tópicos que insertan la escritura en el marco de lo inenarrable o irrepresentable. La muerte como punto de partida de la historia, sus antecedentes de horror y concomitante melancolía así lo corrobora. La búsqueda de la protagonista por esclarecer su origen conduce a creer en la idea de que la sabiduría proviene de este encuentro con la muerte. Esta premisa propia del romanticismo se contradice sin embargo cuando el relato hace énfasis en una narrativa de la psique o "coloquio" interior, lo cual acerca la novela, más bien, a los matices psicológicos del gótico del siglo XIX (Somers 81; Punter 14). 
El estilo melodramático que caracteriza el lenguaje de la novela, parodiado semánticamente por parte de la protagonista, como observa Cosse, se deconstruye igualmente cuando el mismo estilo sirve para insistir en el mito del romance y en las limitaciones del lenguaje, recalcando su aspecto sagrado o el sentido "otro" de una experiencia signada por la pérdida y el vacío. De esta forma, la escritura melodramática como modo de abstracción revela que el mundo de "afuera" o de los hechos es un mundo de apariencias. La "tan mentada historia" oficial apenas registra "el mapa histórico (...) inocuos puntos cardinales (...) referencias para el enfrentamiento" (Somers 83). A esta versión el melodrama la reemplaza por la visión "conceptual” y reconstructora del artista, que Laura describe como una comunidad de "locos en apariencia a quienes les da por escribir poesías, novelas, o inventar paraísos sociales que nunca van a llegar a verse", “orates" que "rumian fantasías" (86).

Aunque en el preludio a la historia Laura dice haber decidido escribir la historia ella misma, la idea de poblar la casa de campo de "estos seres extraños por nacimiento", que "saben ordenar datos, llenar las lagunas a fuerza de imaginación, mantener a la gente en vilo con posibles finales" y escribir al fin la historia de Las nubes, además de resultar muy sugestivo y deliberadamente descabellado, señala el carácter metanarrativo o autoreflexivo de la historia y de su hechura (Somers 86-7). De hecho, en múltiples ocasiones encontramos en el relato la analogía o paridad entre ficción y documentos notariados, novelas por entrega y nombres propios comunes, cartas personales y descripciones interminables de novelones; en otras palabras, una manifiesta igualdad entre novela y vida. $^{136}$

136 “Yo había leído el nombre en una novela por entregas”, escribe Encarnación a Refugio, a propósito del 
La vida como ficción aparece también en Hildegard; vida que imita a la ficción cuando faltan las palabras, tal y cuando conoce al padre de Pierre tras la desgracia y dice: "como en las novelas que no sé escribir, hablamos así" (127). Las cartas para Hildegard son, asimismo, ficción y realidad: "un reflejo en el agua. Es y no es lo real” (132). Esta misma ambigüedad se percibe en el eco de un tiempo inconmensurable, del que Laura da cuenta, profundizando la calidad dual de la novela y su característica resistencia a la clausura o conceptos fijos.

La extraña y compleja temporalidad que se señala en la primera parte y que más tarde Hildegard retoma en sus reflexiones, se corresponde con la forma doble que asume el tiempo en el melodrama y plantea uno de los conflictos más desafiantes en términos del significado de Viaje.... De un lado, la novela postula un tiempo que "es solo uno, el que pasa y no vuelve" (Laura), que "se nace a algo así como se muere, una sola vez" (Laurent), o lo que es igual, que el destino "es uno solo" (Hildegard) $(38-9,95,130)$. Mas, paralelamente, y quizás de un modo más enfático, el tiempo representa ese "no es tan tarde" o esperanza de un tiempo que se extiende desde el presente a un más allá, pues “también parecía que las cosas se nos ofrecieran o nos cayeran como manejadas por un pensamiento de futuro en el acto en que habían sido solo presente" (Frank 541; Somers 92).

Verdugo equipara esta percepción temporal inacabada de la novela con "la experiencia de un mundo distinto (...) [que] se está haciendo presente", como una

nombre que puso a su hija Eulalia. También Laura se refiere a "la novela de Las Nubes"; y en carta a Refugio, le informa que desenredó "las novelescas y abultadas carpetas del notario respecto a Las Nubes". Más adelante le avisa que las cartas están debajo de los "novelones encuadernados en fino cuero de Rusia con títulos dorados a la hoja", y le pide no sacarlas de ahí, pues "en realidad en ese sitio todo deberá ser lo mismo, novela, porque tales cosas nadie las inventa, se van tejiendo solas" (Somers 31,28, 85). 
reivindicación de la vivencia del instante (193). La muerte, el tiempo y el destino participan entonces solo parcialmente de lo trágico, porque esta capacidad especial del melodrama en Viaje..., de

reproducir estos momentos de irresolución proviene de las temporalidades imperfectamente alineadas que se desprenden de objetos, piezas musicales, gestos y otros motivos (...) que hacen posible la extensión de dichos tiempos al presente y al más allá, dejando abierta la posibilidad de su existencia. (Frank 542)

Mozart, la araucaria, los pinos de la Selva Negra, Zauberei, las flautas, son algunos de los motivos que contribuyen a evadir el cierre o la acepción absoluta de lo acabado. Su pervivencia o continuidad se asienta en su calidad simbólica, caracterizada por los afectos, y que aparecen como imágenes del "envés de la trama" o de la contracara de la vida, lo que Hildegard llama el "paraíso" del infierno y Laura "gracia secreta" oculta que separaba los "capítulos [de] la vida", claras referencias al amor (Somers 134, 112, 80).

Memoria, vida y amor, contrario a la cadena de significantes de sus absolutos opuestos atrás mencionados, tienen así un poder e injerencia mucho mayor en la vida propia de los personajes que el sentido terminante y definitivo de la muerte. Así, en la misa de Réquiem de Laurent, Laura insiste en que el mito del romance o "racconto" de su amor está por encima de "su Biblia y (...) Alcorán”, ya que "la vida cuyo término Laurent conocía desde siempre como si él mismo fuera la Divinidad", se negaba "a aceptar su opuesto en términos de absoluto", razón por la que Laurent siempre "brillará (...) como una paráfrasis de Al-ilah" o su "media parte en Dios" (83-4).

La idea de que "la verdad es el vino porque está adentro (...). [y] La mentira es la botella porque está afuera", frase de Encarnación, Hildegard la reformula significativamente, colocando al amor en el lugar de la verdad, como lo verdadero: "el 
mismo amor es el licor" $(75,130)$. De modo que, más que la experiencia de muerte, lo que ocupa el estatus de inenarrable en el relato, lo abismal en sí, es la experiencia amorosa, esa que Laura se esmera en transmitir a Laurent con carteles ayudada "por los títulos grabados de los novelones" de la tía, pues sabía que

allá en lo hondo había una sed de extravasar lo incomunicable, algo que existiría siempre mientras la hierba naciera de una semilla, los insectos se contactaran con sus antenas, aunque el estúpido hombre se empeñara en morir (...) rompiendo así una cadena que debería permanecer entera. (23)

La necesidad de Laura y de Hildegard del artificio "novelesco" para articular lo irrepresentable, coincide con la preocupación del melodrama expresionista por la desaparición de los valores sagrados que, por lo mismo, se han tornado inexpresables y han quedado como un lado marginal de la experiencia (tal el amor y el duelo amoroso). Que esta experiencia esté, por lo demás, asociada en la novela con una en que el sujeto queda "suspendido" y absorto en un "terror irracional", convirtiendo al amor en una especie de "monstruo bicéfalo" o abominable "otro" desconocido en sí, remite al fenómeno fundamental de que trata el gótico postmoderno o experiencia del terror sublime (Somers 68, 74, 24; Beville, Gothic-postmodernism, 15).

La preferencia de Somers por una ubicación temporal de un período de entre guerras para su novela, en una época que puede considerarse asimismo "intermedia" como el fin del siglo XX, adquiere sentido en el marco de la estética gótica postmoderna y del expresionismo de vanguardia, ya que ambos modos abordan la ambigüedad ontológica inherente a los tiempos de cambio, tal como la que precedió la inauguración del modernismo (Beville, Gothic-postmodernism 99). La constante desacralización de la 
disolución moral y discontinuidad epistemológica de la novela está sin duda asociada a la combinación de factores socio-históricos harto inusuales de nuestra época.

Esta deconstrucción de lo que se tiene por sagrado en el discurso dominante y el simultáneo énfasis en el lado marginal de la experiencia, de lo sublime que no aspira a la divinidad por la otredad que la caracteriza, de ser monstruosa y, al mismo tiempo, fuente inagotable de vida, son todos aspectos que reúnen al expresionismo de vanguardia y al gótico postmoderno, y que amalgaman las historias de amor y de muerte que se entretejen en Viaje..., todas experiencias que acercan el horror mítico al horror postmoderno.

La idea fundamental de que el tiempo y el espacio son plurales, de que se basan en la realidad así como en la experiencia subjetiva, es un tropo recurrente de la trama inorgánica del expresionismo y de la discontinuidad de los esquemas narrativos gótico postmodernos. En este sentido, el epílogo de la novela reitera la naturaleza "inconclusa" a que remiten los personajes, y apuesta por un relato "abierto" ("no, el ciclo no se había cerrado aún"), determinado por una doble otredad: la nueva Laura, ahora musulmana, y el mensaje de Hildegard, escrito en griego. La extrañeza de este nuevo "marco" de la novela ofrece una mirada que se acerca a lo fantástico y a lo grotesco, más cuando Laura incluso legitima la "locura" como algo "necesario a fin de que el mundo no desaparezca en la uniforme mediocridad" (Somers 145). Es evidente que una lectura exclusivamente realista del texto resulta inviable, ya que la premisa bajo la cual se rige Viaje... es la indeterminación, que niega la base de esa percepción realista de identidades y diferencias claras.

Dicho final pone, en efecto, en duda todo el trabajo de compilación de las cartas y composición de la historia en escenas supuestamente "reordenadas" de forma cabal, ya 
que el principio de indeterminación se ha vuelto sistema de representación: no sabemos con seguridad de dónde proviene este "último mensaje" escrito en otra lengua, cuyo único vínculo que guarda con Hildegard es la traducción de la frase que había pronunciado a Laura años atrás: "Bésame y dame la mano"; ni un nombre, ni un saludo, nada que indique que sea una carta de ella. Y sin embargo, esta duplicidad fundamental de que lo irracional está invadiendo lo racional no es tan cuestionable como el hecho de que Laura no distingue ya entre significante y hecho, dando por sentado que esto efectivamente ocurre "a través de Al-ilah" (145).

La combinación de formas deconstructivas del discurso dominante en Viaje...—el melodrama expresionista, la parodia, la elegía gótica y el gótico postmoderno-, contribuyen aquí a colocar lo novelesco como referencia de realidad o artificio ineludible para articular experiencias que de otra forma permanecerían del todo irrepresentables. Esto se aviene bien a lo que Linda Hutcheon llama una "visión de interconexión", una mirada que parece indispensable para abordar un relato que admite la historia como una "historia falaz", y que reconoce que la realidad del pasado es una realidad eminentemente discursiva, no objetiva. 


\section{Capítulo 6. Una poética del exceso. "Solo los elefantes encuentran mandrágora" (1986)}

Conocida como la "novela-monstruo" o "intento de novela total”, Sólo los elefantes encuentran mandrágora constituye la síntesis experimental narrativa de Somers, el compendio de su imaginario y la hermenéutica propia que desarrolla a lo largo de sus obras (Niebylski, Patologías postmodernas 254-5; Sick Bodies 98).

Extraordinariamente autorreflexiva, que parodia la validez autoral, cuestiona la credibilidad de los narradores y la de las fuentes, metacrítica, archi-intertextual y autoficcional, la novela ha sido contemplada como un sistema a partir del cual pudiera leerse no solo la obra entera de Somers sino la literatura en general (Pérez de Medina 31). ${ }^{137}$

Los principios estéticos del expresionismo de vanguardia y del góticopostmoderno, recurrentes en sus obras anteriores, se sintetizan aquí en torno a lo que parece una ars memoria, agudizando el combate con la forma y arrastrando al lector con él; pero quizás, más importante aún, sellando el "principio de realidad" de su narrativa: una indagación de lo real en que toda convención artística puede convertirse de súbito en un aliado, tal el folletín, la novela gótica y hasta el rezo guaraní, pues "lo único seguro que (...) queda como dato" al final es la literatura (Somers, Solo los elefantes... 220). ${ }^{138}$

\footnotetext{
${ }^{137}$ Cosse señala de manera enfática que Solo los elefantes encuentran mandrágora "frente a toda la trayectoria de cultura narrativa (...) rompe una fisión fundamental, al instaurar una nueva legalidad novelística" (209).

138 "[P]orque siempre hay que continuar las historias empezadas por uno mismo o los otros, y con eso el que las relató primero se levanta del polvo y echa a andar de nuevo en este mundo que es el más seguro" (Somers Solo los elefantes..., 61).
} 
La calavera

Aunque de manera distinta, Solo los elefantes encuentran mandrágora retoma la misma atmósfera gótica, su imaginería, su humor y simbolismo manifiesto en las novelas anteriores. De forma sugestiva, el narrador parte de una meditación sobre el tiempo que se detiene como el ritmo que definirá la historia que sigue, algo que "parecía haber coagulado como sangre o como leche" (11). La imagen grotesca del tiempo estancado aparece ya como una nota saturada de significados simbólicos, apuntando al miedo al vacío y a la muerte. Más tarde el "aséptico sanatorio", "especie de prisión experimental”, sirve de escenario para recrear la vida de una mujer convaleciente, cuya "rara" enfermedad tiene sus raíces oscuras en las lecturas prolongadas de novelas que su madre le leyera muy joven a cierta "vieja maníaca". 139

Todo el intrigante pasaje puede verse como una representación simbólica de la transformación mental que se opera en la enferma y su retorno al pasado, buscando una explicación a su estado físico. Pero puede interpretarse, también, como un reflejo de la típica concepción gótica del pasado volviendo para acosar al presente, como la silla de la habitación de la mujer en el sanatorio, que a ratos se torna en el antiguo sillón de doña Abigail, la vieja. El estatus siniestro de la protagonista en el sanatorio no es menos perturbador: "Caso único, habitación individual, atención permanente" (16). La ambigua descripción del personaje acaba por enturbiar la percepción entre la realidad y la fantasía,

\footnotetext{
139 "Ella había tenido que leérselas siendo niña a una vieja maníaca que se las conocía de memoria y no perdonaba capítulos salteados. Ahí debe radicar también la causa de esta dolencia. Mucho antes de yo nacer, aquel desgraciado oficio se la habrá hecho contraer, aunque levemente, y luego yo la recibiría en pleno por pura perversidad genética" (12).
} 
cuando las distinciones que hace sobre su historia personal acusan una marcada

conciencia que es al mismo tiempo "seria y burlona" (Botting, Gothic 109). ${ }^{140}$

Los signos de una creciente alienación se hacen más obvios cuando el personaje habla de una soledad "envenenada", de la impotencia e indiferencia que siente ("Para mí ya todo era lo mismo") y de la completa pérdida de valor como individuo, "donde ya no se puede levantar la vista porque la función es incompatible con mirar a los ojos de nadie, y toda la indefensa condición humana bajo control” (Somers 26-7). La enfermedad, en estos términos, se manifiesta aquí como el detonante de la incertidumbre, cuando el "sentido persistente de disolución entrópica" (la linfa desbordada por el interior de su cuerpo) recrea el estado liminal inherente al terror en lo que parece un sacrificio sin fin, una "moratoria indefinida del vacío" con su "inacabable espera" (Niebylski, Sick Bodies 102; Somers 104, 108). Y aunque en el sanatorio “estaban todos vivos aún” la vida era un sinsentido, pues "había que seguir remando sin saber para qué. (...) ¿Hacia dónde se iba? (56).

La expresión de esta idea se encuentra a lo largo de la novela. ${ }^{141}$ Mientras que el terror del día a día es la fuente de ansiedad de la protagonista, es el terror inherente a su

\footnotetext{
140 "Nombre: Sembrando Flores Irigoitia Cosenza, o Fiorella, o Sembrando Flores de Médicis, segunda época. Edad: La de sus dientes, aún todos naturales. Estado civil: viuda de Dante Alighieri. Ocupación: trabajar con recuerdos. Enfermedades anteriores: otitis reiterada en la infancia, pero con cura radical en el mismo período por medicina de excepción. Antecedentes familiares: novelísticos. (...) ¿Antecedentes psiquiátricos?: oh, sí. Conflicto ideológico familiar catolicismo conservador versus definición de Spencer: Yo quería un mínimo de gobierno... Búsqueda de la Mandrágora e inconclusa limpieza de un aljibe en la niñez. (...) Síntomas actuales: cierta combinación brutal de tos, ahogos, dolor de espalda, palpitaciones y un sentirse desfallecer" (16).

141 "Y a eso quedaría reducido todo: la esencia, la existencia, pero principalmente el ser ahí como alguien muy oscuro y muy claro habría llamado al ser en el mundo" (26). "un nuevo deslizarse como en los caños, aunque esta vez para recuperar al igual que aquellos otros la dudosa libertad de afuera" (28). "la presión de la angustia fundamental, seguir marchando como una locomotora que perdió los vagones" (146).
} 
propia subjetividad el que responde a lo sublime. Lo insólito es que estos encuentros sublimes con el terror que la acosa provean una suerte de alivio o escape de la narrativa del mundo "real" por medio de una novela gótica: los mismos folletines "responsables" de su enfermedad, Los manuscritos de una madre. ${ }^{142}$

Aunque los críticos no ven en esta estrategia una ironía gótica del texto, sus posturas amplían el sentido de la función del folletín. Para Susana Zanetti y Elia Geoffrey Kantaris estos representan tanto un "refugio" para la enferma como una vía estructural de la composición de la obra, algo que Nuria Calafell Sala explica mejor al decir que en esta novela como en Viaje al corazón del día (1986) Sembrando Flores, al igual que su antecedente Laura, relee los Manuscritos... amén de "recomponer las piezas rotas de su historia personal" y de "cuestionarse acerca de su propia naturaleza subjetiva" (Zanetti 50, Kantaris 113, Calafell Sala 53). El uso de los folletines como vía de autoexploración lo admite la misma protagonista cuando interrumpe enfurecida la visita de los doctores con la lectura de la novela (los folletines de Pérez Escrich), pues era "necesario reconstruir el momento cumbre, o sea aquel por el cual se nació" (Somers 41). ${ }^{143}$

El esclarecimiento de su origen como intención de esta lectura remite de entrada al presupuesto gótico postmoderno de radicalizar la búsqueda epistemológica del sujeto por medio de la metaficción (Beville, Gothic-postmodernism 46). Asimismo, los fragmentos del folletín y la historia que gira en torno a ellos (la de la lectora ferviente, Abigail, y la madre de Sembrando) ofrecen a Sembrando "un espacio de libertad, de

\footnotetext{
142 "Las novelas de Abigail traspasadas a la memoria del feto por la sangre de la madre habían tenido tanta cavitación en sus fuerzas (...) como cualquier sustancia (...), allí radicaba todo” (228).

${ }^{143}$ Ante la llegada de los médicos, Sembrando "podría salir corriendo desnuda como estuviese si las venas no respondían al inyectable, o arrojarse por la ventana si el aire inspirado le resultaba escaso. Y así se llevaron el frasco y vinieron con la jeringa para la endovenosa. ¡La novela del Conde, o el cuaderno, o lo que sea! Empezó a clamar" (41).
} 
encuentro con otro mundo propio, que le permite soportar la realidad extra-textual, siempre terrible" (Pérez de Medina 35). A este respecto Diana Niebylski aporta una observación de interés. Para ella las novelas de Pérez Escrich, autor de los Manuscritos..., operan como un vehículo mediador entre la lectura y la enfermedad de la protagonista, pero a manera de "una admonición preventiva" (Patologías postmodernas 261). Por una parte, Niebylski se refiere al carácter moral y aleccionador de la historia del siglo XIX, en tanto que narra las peripecias de Pedro de Lostán, un "militarcito" que fraguaba emboscadas, y su aventura amorosa con Margarita, especie de femme fatale que lo traiciona con infidelidades. Sin embargo, en la novela el folletín tiene una implicación más pertinaz y tiene que ver con la imagen de la calavera que aparece no solo descrita en la narración, sino retratada en el grabado impreso en las primeras páginas de la obra (Somers 15).

La calavera de Margarita y la inscripción que la acompaña "Ese cráneo que te sobrecoge" subraya el estatus corrosivo de la muerte que impregna toda la obra, su fuente primordial de terror. Esta imagen juega aquí un rol "admonitorio" doble. De un lado retrotrae aspectos del gótico romántico caracterizados por el miedo y la fascinación simultánea, mezcla de emociones presentes en el carácter sublime del gótico de todos los tiempos (Beville 178). ${ }^{144}$ Mas como arquetipo medieval, romántico y símbolo del gótico, el ángulo cartesiano de su aparición es palmario: la figura está atrapada en el mundo subjetivo de la mente y la certeza de que nada existe más allá de él (79). ${ }^{145}$

\footnotetext{
${ }^{144}$ Es significativo que la primera página del libro que Sembrando Flores abre al azar fuese "el grabado de una escena dominada por una calavera", lo que le pareció "lo más sugestivo" y que le traía "el sabor del pasado absoluto (...) en la boca como si una uva hubiese quedado intacta en el vino" (13).

145 “Toser, llorar y preguntarse cosas que nadie contestará ya porque los actores desaparecieron de escena en un teatro derrumbado, es una mezcla impura que jamás se ha guardado en una botella", "Y entonces, si
} 
Notoriamente, el aspecto distractor del folletín y la comicidad que se desprende del contraste, el carácter absurdo de las reacciones de la enferma, que llora y pronuncia frases como “¡Pobre mi hijo Escolástico!” sin venir al caso, es donde apenas comienzan las referencias al gótico más tradicional. Mientras este humor suaviza las tensiones de la enfermedad abrasiva y de sus tratamientos terroríficos, otras referencias se despliegan de actitud más seria hacia el gótico y su concomitante obscura filosofía.

La burla

El detalle más llamativo de la calavera en el grabado, a juicio de Sembrando, era el hecho de que sirviera de "lámpara portátil" y de "encendedor" al viejo Conde, antiguo amante de la muchacha, y cuyo cráneo vigilaba todo "con sus redondas órbitas desde una chimenea" (19). Pero tal dato al lado de la realidad clínica parecía, asimismo, irrelevante: "Sí, es claro, hay cosas más importantes, por ejemplo, que ella esté enferma de algo que quizá no se sepa nunca a qué se ha debido, y (...) dónde terminará” (19). La comparación resulta reveladora cuando Sembrando justifica la vuelta a la lectura del folletín para descubrirlo, afirmando que eso es "lo normal" (seguir leyendo), pues "nadie debe dejar un relato cortado al medio en su punto crítico sólo porque en el año mil ochocientos y tantos ocurrieran aquellas tremendas cosas que hoy a nadie le quitan el sueño, sencillamente debido a que hay que dejarle el sitio a otras peores" (19). El terror actual se suple entonces por otro más viejo pero no menos escalofriante, pues también en este punto sembrando añade “Cada época parece apocalíptica ¿no es así?”(19).

se está en la cama, se echa pie a tierra, no se mira el reloj, para qué, y se sale de la pequeña rutina. Pero todo eso en apariencia porque en realidad es el presentimiento de aquello otro que empuja" $(20,204)$. 
Lo inicuo, lo pormenorizado por el olvido adquiere importancia en la medida en que se asocia con el misterio de la muerte: el cráneo de Margarita, lo que la llevó a estar absurdamente expuesta en la sala del Conde, pero también Sembrando, con su rara enfermedad, sintiendo la muerte tan de cerca. El tipo de experiencia al que alude por medio de sus meditaciones indica que detrás de lo aparente, de estos elementos concretos (la calavera, su cuerpo enfermo) se erige una realidad "otra", pero de la que nadie se entera, pues mientras descansaba en el sanatorio "llegaban convocados al impoluto cuarto blanco miles de actitudes posturales ante aquella duda, lo real-irreal, lo que es sombra en la caverna, el río que nunca va a ser el mismo, (...) nada de eso sabía el doctor Nessi cuando entró el mismo día e informó" (34-5). Ni tampoco

La evocación de la carta descubierta el día de la subasta en Las Siete Ventanas, el diálogo incisivo con el hematófogo actual, la mujer que quería vampiros de verdad sin atreverse a confesarlo, Abigail y su retrato en el marco de la recreación conjetural, todo aquello debería pesar sobre sí, y sin embargo nadie lo advirtió en la silla de ruedas camino al gabinete de rayos (...) nadie la oyó. (67)

"Todo era natural, pues, el orden de este planeta venía desde tan lejos que ningún accidente individual podía trastocar sus esquemas" (68). Y así continúa Sembrando Flores declarando su miedo, hasta concretar la situación de total enajenamiento y el motivo de la incomunicación fundamental de la experiencia:

Los estallidos, las tormentas, las revoluciones, eran más bien por dentro, lo que no puede percibirse, lo que nadie logar transmitir, sencillamente porque tendría que existir un receptor que en ese mismo instante estuviera en lo mismo sin matiz diferencial alguno. (68)

Las cavilaciones del personaje en su conjunto claramente remiten a un tipo de vivencia irrepresentable. Sembrando habla de una realidad común y cualquiera, que a nadie afecta por su normalidad, pero la verdad que trasunta es de otro orden, pues siendo 
exteriormente algo familiar y reconocible, es al mismo tiempo un misterio, lo desconocido. La muerte, el "mayor de los terrores", funciona aquí como un punto de referencia central al gótico en la novela cuando ni los folletines, ni las visitas, ni los cuadernos que escribe Sembrando en sanatorio logran evadirla:

En cambio Aquello era invulnerable a toda mofa, soplar su cara con mil historias no le causaba merma alguna, y eso naturalmente, sin las falsificaciones cobradas en el estado químicamente puro de la desgracia, y sin rechazar tampoco las más desemparentadas situaciones. (33)

La paranoia se manifiesta, igualmente, en la forma en que Sembrando relaciona las pisadas en una calle solitaria con una melodía:

Escuchen: esos pasos y el silencio se corresponden como en la música. (...) Un simple golpetear acompasado del martillo en la madera o el metal o la piedra es capaz de crear esa música y sus silencios, y el oído que se acostumbra a la doble captación está preparado para morir. (104)

Toda la secuencia de este espacio liminal inherente a una dimensión de la experiencia que es, por definición, espectral, se plasma en la paranoia delirante de ser ella misma un fantasma esperando el vestigio futuro de lo que es, pues era "la propia sombra de la aplazada muerte vigilando el cuerpo" (108). El terror gótico asume aquí entonces una calidad que es poética y terrorífica a la vez, en tanto que nos presenta un tipo de ansiedad que va precipitándose a lo sobrenatural en la imaginación desbordada de la protagonista, el cual se materializa en el efecto sublime de la luna y en el terror de un cuerpo análogo al de un muerto en pena: "La luna había segregado una visibilidad extraña, y cierto que largarse sobre y bajo aquel cuerpo espectral, con frío hasta en las uñas, atravesando los campos y sus baches para llegar a un pueblo" (205). El estatus fantasmal, de muerte que es sombra de muerte, condensa la obsesión del terror sublime y la subjetividad cuando 
torna el mundo real en uno hiperreal y conduce al personaje a una pérdida de identidad, en un ser "inaprensible":

[E]1 horror estaba en uno mismo (...) "una malformación congénita en las vías linfáticas.” Era entonces como saber que la vida se había rebelado por dentro después de estar sentada incómoda tanto tiempo (...) Y ahora el no ser, el no existir (...) Pedro, Esculapio, Marianna, Abigail y sus huevos sin yema, (...) será mejor dormir y voy a hacerlo cuando pueda. (Burke 86; Beville, Gothic-postmodernism 179; Somers 146)

La muerte simbólica como forma espectral y sobrenatural de la existencia ofrece una visión aciaga del misterio de la muerte. Al concentrarse en esta idea, la novela puede verse como un intento por expresar el terror que amenaza la cultura contemporánea, en particular en las obras gótico postmodernas, donde no se trata tanto de la muerte física o personal, sino de la identidad. Por eso la madre, Marianna, el novio a quien ella dejó, Abigail, Pedro, su padre, toda esa cosmogonía fundacional llena de significados los coloca a la par de su propia inexistencia.

Significativamente esta “obsesión con el fin”, propia del gótico y de la posmodernidad, se alía aquí con una estrategia “diabólica”, algo que la protagonista describe como "la burla" (33). Esta burla debía ser capaz de trazar un intersticio entre "el ciprés y los renovados frascos" (la muerte y la linfa), y consistía en el relato "otro" que ella iba a narrar, que no era el de los folletines, sino el de su dueña original, Abigail de la Torre "comenzó a desenvolverse entonces la historia que nadie escuchó en la habitación, y he ahí el milagro, poder birlarles algo con las malas artes de la cerrada mente" $(113,13-$ 4). Esta intención vengativa, en principio dirigida al sanatorio, los enfermeros y toda aquella "trampa" del lugar, se torna no obstante ambigua cuando en este punto la muerte parece ser el verdadero interlocutor: "la muerte parecía muda y ciega, ¿pero sería sorda? 
Y si no lo fuera, con qué palabras acercársele sin ahondar en la conciencia de que estamos muertos" (240)

Lo indecible y lo extraño

Dada la rareza de la enfermedad terminal de la protagonista llamada "Quilotórax" y el también no menos extraño nombre de "Sembrando Flores" el relato en sí parece convocar a una suerte de locura narrativa, idea que se refuerza en la historia que cuenta la protagonista, entremezclada con la novela de Pérez Escrich, la historia de Abigail y su madre, diálogos con seres dudosos (un ángel, Pasifae, Schreber, una soñante, por mencionar unos pocos). La historia principal regida por Sembrando Flores y su entrada al sanatorio se interrumpe por la de su madre y Abigail, "la tiránica mujer", esta última lectora original de las novelas góticas que Sembrando decide leer en plena convalecencia. Leemos, pues, en parte, la historia que le leen a Sembrando, que a su vez su madre leía a Abigail. ${ }^{146}$

La estructura — dominada por una narradora omnisciente — coloca a Abigail (mujer que había muerto a finales del siglo XIX) prácticamente en el mismo espacio de tiempo que el de Sembrando, imponiendo un significado maléfico sobre su presencia en la vida de la protagonista. Todo esto ocurre en un estilo indirecto libre en que el lector a ratos desconoce si es la protagonista o la narradora quien habla, y, pues, al final de la novela nos enteramos que todo lo escrito ha sido compilado por una tercera persona llamada Victoria von Scherrer, toda confiabilidad en el texto queda en entredicho. Ciertos

\footnotetext{
${ }^{146}$ Hay un mise-en-abîme de historias, pero también de la figura del lector. Y así nos vemos proyectados en la misma acción que realiza Sembrando Flores, que realizaba Abigail antaño y sucesivamente, como un cuadro que se repite y que nos incluye en la trama.
} 
comentarios del narrador hacen pensar, además, que el personaje no está en sus cabales, como cuando dice de cuando entró al sanatorio que esta sufría de un "delirio apirético. Pero todo el mundo la perdonaba entonces, aun sin descifrar nada" (14). El argumento de base constituye así un marco estructural que tiene el efecto de tornar la protagonista de la historia en una enferma bordeando la locura, impresión que se acentúa cuando la mayoría de los eventos parecen ocurrir solo en su mente.

Y, sin embargo, como apunta Doreley Carolina Coll, "leemos un discurso de 'locura' (...) que no obstante gozar de un lenguaje propio (...) comprendemos” (91). La lógica particular que rige la maraña de identidades y fenómenos, subversiva de cara a la racionalidad y al relato realista, tiene, como apunta el Conde de los folletines, un mensaje revolucionador frente al mensaje "conformista" o meramente aleccionador que encierra. ${ }^{147}$ Esta estructura en que la ficción enmarca la realidad (los folletines dando claves sobre la historia de la enferma) es precisamente la deconstrucción de la realidad a la que la organización discursiva "caótica" de la protagonista apela.

El primer eje de ambigüedad en el relato puede verse en la repetición, marcada por la persistencia de figuras que reiteran situaciones, comportamientos y frases. Esto ocurre, además en dos planos distintos: en el plano de las historias que narra la novela, pero también, en relación con personajes y motivos distintivos de las novelas anteriores de Somers. Curiosamente, estas reiteraciones del texto consigo mismo y con las novelas anteriores parecen confirmar e incluso incrementar la identidad "original" a la que refieren, no obstante reforzar, también, la complejidad y la problemática de la obra. Lo

\footnotetext{
147 “Escucha la historia y, al terminarla, una nueva luz brillará en tu inteligencia, un nuevo camino se abrirá ante tus pies, porque ella te enseñará de lo que es capaz una mujer..." le dice el Conde a Daniel, advirtiéndole de las malas mujeres que traicionan, para que no le pase lo que a él (20)
} 
que es importante resaltar aquí, es que estas repeticiones se caracterizan por tener en común una nota "negativa". La imagen de la mano del Conde arrancando de la tumba el cráneo de Margarita se refleja en las "manos del otro mundo que pendiendo de un brazo curvo (...) tocan fugazmente el aire preso del cuarto donde alguien se hace a pedazos, juntan esos trozos y el ser se recompone mediante la tregua", algo que le acontece a Sembrando tras momentos de crisis y que significativamente ella llama "el fenómeno" (20-1). ${ }^{148}$

El vacío, otro de los principios del terror sublime presente en todas las novelas de Somers, aparece en un recuerdo de Sembrando quien en "la feroz adolescencia cierta madrugada atravesara un campo", al igual que Rebeca en La mujer desnuda, "en la que el Todo y la Nada se (...) habían venido encima como lobos hambrientos de interrogatorios. Y he aquí que la inconcebible nada de otrora retomaba con nuevo rostro, este sí que terrorífico, el del encuentro con el vacío interior” (337)

Lo que resulta extraño de estas repeticiones es el efecto de inefabilidad de la representación de los motivos, los temas y las situaciones. Es evidente que esta forma discursiva caracterizada por la multiplicidad tiene que ver con las típicas deformaciones expresionistas de subversión de modos de percepción, y las cuales están vinculadas con la infinita expansión de lo irrepresentable y la experiencia imposible de lo real, propios de gótico posmoderno (Beville, Gothic-postmodernism 200). Como es común en estos casos, la inefabilidad — principio sobre el cual se estructura la novela - se transforma en una dramatización de este estado típico de crisis epistemológica. De modo que la "crisis

\footnotetext{
${ }^{148}$ El "fenómeno" era también lo que le ocurría a la niña en Un retrato para Dickens: "sentir que ya no se estaba en el suelo, sino que se iba planeando a corta distancia de la tierra (...) pero sin apoyo" (Somers Un retrato, 18).
} 
de percepción", de "unidad corporal" y "fenomenal" asociada con la experiencia de ser incapaz de dar con identidades, es una forma de desestabilizar y cuestionar los presupuestos racionalistas y los discursos dominantes, configurando una fusión literaria de múltiples perspectivas del lado oscuro de la subjetividad y diferenciándose de lo "natural".

Es en esta estructura ambivalente del plano narrativo donde la caracterización y el mise-en-escéne comparten la forma del sueño o trance hipnótico inherente al expresionismo y al gótico posmoderno, el cual se manifiesta en la duplicación de las figuras y la repetición de importantes eventos. Sembrando rememora a Abigail por su enfermedad y sus lecturas, no obstante el hijo exiliado de Abigail, confinado en una cabaña por su enfermedad, se asocia a Sembrando por su aislamiento y su dolor, por las cartas que escribía (al igual que Sembrando), el abandono de Dios y, finalmente, la mandrágora. En el reproche de Cantalicio a su madre por el abandono y la inanición se repite el reproche de Sembrando a Abigail por el trato a Mariana (su madre). Otras figuras reflejan ideas de Sembrando, como "la soñante", que tenía visiones y que prefería el sueño a la realidad. ${ }^{149}$ Los diálogos que sostiene Sembrando con el Magistrado Schreber, el doctor Cósimo y todos los personajes imaginarios y reales que se sentaban en el banquillo a escuchar a la enferma, son, asimismo, caracteres que se corresponden con la representación expresionista, cuando constituyen dobles, visiones o posturas del

\footnotetext{
149 "La soñante quedó por unos momentos como superada por lo inexplicable. A veces, dijo, yo no entiendo nada de lo que sueño, pero no quisiera despertar, me parece que el mundo es sólido allá y que lo de aquí se deshace como una nube de humo, o que aquello era el cuerpo y lo de acá sombra...” (34).
} 
personaje principal. De hecho casi toda la estructura de la novela está organizada como en un sueño. ${ }^{150}$

Esta recurrencia de eventos surgidos como de un estado de duermevela, y de desplazamientos de la identidad del personaje, primero como reflejo de Abigail, luego como continuum de la madre, como reflejo de Margarita, de Cantalicio y así, por mencionar los caracteres que mayor injerencia parecen tener en ella, pueden clasificarse dentro del ámbito de lo extraño, de la duplicidad y de la inefabilidad. El tipo de estructura onírica que enmarca la estructura narrativa pone en cuestión cualquier orientación racionalista que intente ver las distintas figuras, eventos y diferentes niveles de la narración de forma separada. ${ }^{151}$ Con lo cual parece claro que la inestabilidad y duplicidad del texto, al igual que la linfa en la enferma, contamina toda la estructura narrativa, produciendo una discontinuidad típicamente expresionista de vanguardia y gótico posmoderna, cuando cuestiona las distinciones entre lo real y lo irreal, la lucidez y la alucinación, la conciencia y el sueño.

\section{La transgresión, el exceso}

Al igual que la dualidad de Sembrando Flores, que desde el principio se demuestra en la ficha del sanatorio, en las dos versiones de su nombre dividas en dos

\footnotetext{
${ }^{150}$ Hay claves concretas en la novela que así lo señalan, la más evidente es cuando Sembrando Flores ante una mala noticia o tras uno de los fuertes tratamientos, exhausta, prefiere "cerrar los ojos", "así era mejor estarse, por otra parte, para atrapar significados huidizos", "querría en adelante lo sobrenatural, un espiritista o algo así que cambiara el panorama a las resecas esperanzas favoreciéndole el escape por cualquier puerta" (Somers 37-8, 90).

${ }^{151}$ Kantaris ha hecho la observación de este angosto margen que se percibe en la novela, de estar al borde del sinsentido y de la psicosis, en tanto que toda la estructura novelesca obedece a una ordenación que tiende a disgregarse o "diseminarse" contradictoriamente entre el horror y la fascinación por lo abyecto (99). Por lo demás, todos los críticos coinciden en la enorme dificultad que representa el texto para el lector, quien, entre tantas líneas de orientación para una supuesta misma historia debe ingeniárselas para no perderse en el caos (Niebylski, Sick Bodies 106; Coll 206; Mandolessi 134).
} 
etapas, llama la atención, asimismo, el título por su carga de connotaciones infinitas. La aparición de estas imágenes (elefante/mandrágora) a lo largo de la novela subraya el carácter nebuloso de la obra, cuya deconstrucción de formas, motivos, posturas ideológicas, supersticiones, prácticas médicas, etc. parece indicar que todo el lenguaje del texto en su conjunto debe ser entendido estrictamente en clave simbólica. Quiere decir que el lector está obligado a ejercer la práctica hermenéutica de abordar el texto como “infinitamente interpretable” o deconstruible (Eco, Semiótica y filosofía 262). En este marco de ideas el texto propone una lectura de la obra cercana a la experiencia del místico, la cual es "fundamentalmente amorfa, indeterminada, inarticulada" en la medida en que la experiencia que allí se retrata es un conjunto de visiones amorfas, de símbolos en permanente deconstrucción y enriquecimiento imaginal, como si en efecto se tratara "la vida como contenido de la experiencia humana última, esto es de la mística" (259). ${ }^{152}$

Particularmente la constelación de significados alrededor de la imagen de la mandrágora está asociada a lo irracional del ser y a una suerte de poder de autocreación cuando remite a la fuente alquímica de los pequeños seres surgidos de las raíces de la tierra, los homúnculos (Somers 68). ${ }^{153} \mathrm{El}$ sueño como realidad más real y mejor forma de concebir el mundo está asociado a la mandrágora, que le servía a Sembrando Flores “para sobrevivir en un discreto mundo elusivo" y que era mucho mejor que "sumarse al safari

\footnotetext{
${ }^{152}$ La misma Sembrando Flores alude este modo de percepción o de representación como algo primordial e inherente a la condición de la naturaleza y del mundo: "¿Y sabe alguien lo que es la calle, no como otro trazado más o menos urbanístico sino por lo que vale en símbolo? (...) La calle es el paraíso circulatorio aún no descripto. Mas para quienes la recobran con su pleno sentido desde una ambulancia a toda máquina se transforma en un mundo entreverado que parecería querer darse en una sola vez hasta provocar el atoramiento. Y lo que predomina no son los edificios, ni los vehículos ni aun la gente, son sencilla y paradójicamente las naranjas" (28).

153 "Esa planta curiosa tiene una raíz muy parecida a la figura del hombre. Ciertos místicos ven en ella el vestigio umbilical de nuestro origen terrestre. Lévi mismo piensa que el hombre, al principio, tenía forma de raíz. Por analogía, infería que los primeros hombres eran de la familia de la mandrágora...” (130).
} 
racional que orillaba sin atravesar "la selva oscura" (39). La mandrágora, como el sueño, era también el punto en que se borraban las "colisiones entre carne y espíritu", entre "guerra y paz" y donde desaparecía "la peste de la pobreza concientizada" (129). La metáfora continua hasta abarcar el mundo interior de cada cual, verdadero sostén de la vida. ${ }^{154} \mathrm{Y}$ no obstante, la transgresión del símbolo se opera con mayor fuerza cuando la mandrágora es también fuente de la locura que, al igual que la raíz de la planta según los alquimistas, no debe de machacarse tanto aunque sí triturarla "en el mortero de los siete metales", como decir, conociéndola con cautela (292).

Las distintas "prácticas" que acompañan esta extraña filosofía, que se relacionan con el carácter nocturno y sospechoso de la protagonista, con poder de "facultades psíquicas", "visiones metafísicas", "como Santa Teresa o San Juan de la Cruz habrían visto las suyas", con "percepción extrasensorial”, como "poseída", “como hipnotizado por una mira situada más allá de la común visión bilateral del ser humano surgido de sus evoluciones", son claras representaciones de un estatus alterado de la percepción en que simultáneamente se concilian las identidades del símbolo y revelan, pese a la multiplicidad de significados, la identidad y el agenciamiento del deseo: mandrágora/sueño/locura/misticismo-interioridad-realidad profunda (Somers 49, 274, 12, $53,317)$.

La defensa de lo irracional es clara por parte de la protagonista, quien al decidirse por esta realidad "otra", que primero asocia a "las malas artes de la cerrada mente" y, más tarde, refuerza con la necesidad de "seguir refutándolo todo dese el estricto ángulo

\footnotetext{
154 "Nuestras mandrágoras, esa puerta que sólo se abre para uno mismo (...). Falto de mandrágora, el cuerpo extendido del hábitat aparecerá limpio, sin temperatura ni recuerdos, algo así como un muerto lavado y peinado para el entierro" (132).
} 
absurdo" a fin de sobrevivir en el mundo de la "normalidad" donde "todos están muertos", materializa no solo una exploración profunda del lado oscuro de la subjetividad, sino que se desentiende, además, de los esquemas dominantes que regulan la vida en la sociedad, ambos objetivos cruciales en la estética expresionista de vanguardia y en el género gótico postmoderno (Somers 19, 35, 40).

Otro aspecto transgresor de importancia en el texto tiene que ver con la noción de totalidad y su función en la novela. En términos estructurales, puede decirse que se despliega una evidente ambición narrativa que busca abarcar el todo de una experiencia de vida desde la situación irrepresentable por la que atraviesa el personaje principal. Empezando por su infancia y su origen (Pedro, Mariana, Abigail, Los Caña), pasando por el registro de todas las fases de su vida por "épocas cromáticas", que incluyen todos los personajes, lecturas, escritores, casos psiquiátricos, teorías científicas, históricas, políticoanárquicas, etc. que formaron parte de ese recorrido, hasta llegar a la enfermedad, hacen pensar, efectivamente, en que se nos entrega un recuento autobiográfico llevado a cabo de la manera en que lo plantea el protagonista de De miedo en miedo. Los manuscritos del río. ${ }^{155}$ Esta percepción del relato como "mega-novela" "de ambición monstruosa", "imposible de reducir a una temática o trama narrativa" de la que dan cuenta los críticos, podría entenderse entonces como el intento de representación de la totalidad de la realidad (Niebylski, Sick Bodies 255, 267, 97). No obstante, la monstruosidad a la que

\footnotetext{
${ }^{155}$ Recuérdese cómo el protagonista expone la teoría hipotética de la novela "para la que no se necesitaría ser escritor ni nada de eso. Que se pudiera componer con otros elementos más a la mano de cualquiera, por ejemplo de dibujos mal hechos, cajones llenos de esas cosas que significaron alguna vez y luego se hicieron basura. Trapo quemado de vida que se gastó diciendo buenos días a todo el mundo, gente fotografiada en el momento de perder el orgullo, con la boca, las uñas y los ojos agarrados al aire al errar un pasamanos. Y muchos materiales más... Quién sabe si con largos períodos en blanco" (Somers, De miedo en miedo 66).
} 
remite la novela, dicho en sus propios términos, como "Leviatán" que nace de

Sembrando Flores, no pretende abarcar el todo, pues

el Todo no existía porque era algo hecho en unos pocos y brutales golpes de creación pro inmensidad, y a nosotros nos daban a mirar pequeños pedazos, a tocar diminutas zonas (...). Felices los dormidos, estar despiertos era algo terrorífico (...) ¿Pero y entonces yo qué soy? La Nada, la Nada absoluta. (...) la Nada del gran vacío. ¿Pues existiría el absoluto vacío, qué habrían dicho de eso los libros de El Hombre? (...) No existía, entonces, el Todo porque éramos incapaces de abarcarlo, ni tampoco funcionaba la Nada para una mente sin datos. Ella, pues, no alcanzaba a ser ni siquiera su intermediaria para quien fuera el maese creador de aquel enredo del vivir sin explicaciones, mirando hacia arriba y hacia abajo como alguien que se ve venir la lluvia (...). Porque aun existiendo en algún punto la Nada del vacío ¿no estaría bajo ocupación de algún proyecto? (...) bien pudiera ocurrir que en cualquier pequeño intersticio de la nadidad estuviera la pulsión proyecto, y entonces meter el dedo allí sería un peligro. (205-6)

Críticamente, la novela sigue el postulado expresionista de vanguardia, cuyo impacto se revela en el pasaje anterior donde tal organización clásica de representación en que la imágenes aparecen ordenadas según la realidad fáctica, se diluyen a favor de la arbitrariedad, cuestionando la validez de los meta-discursos, tales como una base teológica que permita reconciliar al personaje con la realidad que vive, ni tampoco con la no-realidad, la incertidumbre. En este punto, la novela como contradiscurso que posibilita nuevos modos de percepción se proyecta también, cuando asoma la alternativa de la nada como un plan o, en todo caso, parte de un proyecto siniestro, aludiendo indirectamente a Dios.

Solo los elefantes... retoma la idea de un Dios ajeno a las vicisitudes humanas, imagen manifiesta aquí en repetidas ocasiones, donde aparece como un ser caprichoso, pues "lo que Dios quiere o no quiere, eso nunca se sabrá" (14). Y Sembrando Flores era 
"un ser así tan dejado de la mano de Dios", él apenas se limitaba a "acarrear cadáveres", como un perfecto "Ateo" que "estaba solo para los muertos" (Somers 209, 80, 35, 54). Pero en esta novela aún se desarrolla otra percepción de Dios, a saber, la de un "Dios sufriente; no triunfal que agoniza como Jesucristo", ni por "solidaridad con la miseria humana", como apunta Slavoj Ẑiẑek, sino por estar encadenado a un "sistema" absurdo del que solo los hombres "locos" podrían liberarlo — locura, por cierto, enviada por él— $(136) \cdot{ }^{156}$

El carácter subversivo de esta percepción divina concuerda con la desublimación propia de Somers, como apunta Blixen, en relación con el afán de la escritora por distorsionar toda posible forma trascendencia (206). Esto se aviene, igualmente, a la típica desestabilización de los órdenes dominantes de configuración de la experiencia, una vez que, en lugar de ofrecer al lector una perspectiva armónica que le transmita una ilusión, en este caso, de alivio (alguien carga con toda la culpa y el horror del mundo por mí), coloca a Dios de un lado más bien maníaco y victimizado, igual o peor que cualquier mortal.

Ahora bien, el presupuesto expresionista en la novela no se queda en la inversión del orden para reemplazarlo por otro. Esta imagen de Dios también está en entredicho como toda la oposición del orden divino-diabólico de Somers—, cuando Sembrando Flores no es solo la "viuda de Dante Alighieri" sino su "asesina". ${ }^{157}$ El "danticidio" de

\footnotetext{
${ }^{156}$ De una visión de la soñante: “yo, como la abejas, muero cada vez que clavo el aguijón en mis criaturas. Sólo que el inexplicable aguijón me nace de nuevo y yo con él. Y que no colecciono cadáveres como ese hombre creía. Yo muero a cada instante dolorosamente, en cambio cada hombre muere una sola vez, con lo que sería mucho mejor ser eso. Pero estoy, no se sabe cómo ni por qué, en la cúspide del sistema, y de ahí no podré salir sino de tanto en tanto, cuando a alguno al que le mandé la locura más refinada se le ponga en la cabeza la idea de morir por mí (Jesús) y entonces, ese único día, yo descanso" (56).

157 "Pero existe el momento signado por el crimen, una especie de yecto irresistible, un relámpago de
} 
Sembrando Flores concreta, de por sí, el leitmotiv y eje central del expresionismo de vanguardia, que es justamente el de crear un modo de visión en permanente fluidez. ${ }^{158}$ Pérez de Medina traza una analogía interesante en relación con el intertexto de la Divina Comedia. Ella observa cómo el infierno que deshace Sembrando de niña se alía con el infierno novelesco, en tanto que es justamente en ese tramo de la cosmovisión dantesca donde "en gran medida se concentran la mayoría de los tópicos de de la literatura occidental", pero además es el lugar, también, donde están todos los que se excedieron y donde el mismo Dante ejerce la libertad poética con mayor autonomía (32). Siendo este lugar el espacio del exceso por antonomasia, siguiendo a Pérez Medina, resulta aún más monstruoso "matar" el exceso como lo hace de protagonista al llamarlo danticidio, lo mismo que liberarlos, tal vez, soltándolos en el río como barquillos al mar.

\section{La expiación}

La inestabilidad de la representación de la novela puede considerarse entonces como una respuesta, tal la estrategia expresionista y la literatura gótico posmoderna, en rechazo a toda imagen que reclama ser objetiva u "original". El estatus de provisionalidad y de continua fluctuación de identidades, situaciones, motivos, géneros, temporalidad y

dentro a fuera que se ríe de la letra escrita (...). Entonces fue cuando me sentí empujada hacia el voluminoso libro por alguien que no era yo, pero que estaba tan emboscado en ni al punto de actuar con mi propia materia gris, mis propios e intransferibles brazos y sus manos. Y por ese perfecto dispositivo Morse, el manipulador, el receptor, el hilo conductor, mis dos yo se comunicaron, y uno de ellos, quizás el más pobre diablo por lo comprometido, se echó sobre el libro y empezó a arrancarte paciente y prolijamente sus hojas. (...) Luego el otro yo, más adiestrado en cosas aparentemente inocuas, iba haciendo unos elementales botes de papel con destino al agua de afuera que ya llevaba dirección definida de corriente: infierno, purgatorio, paraíso, todo sirve para un eclecticismo desenfrenado" (120).

\footnotetext{
158 “[T] he historical avant-garde sets about deconstructing conventional configurations of experience and perception, yet (...) it does so without substituting for the established patterns a new set of fix values of its own. For it is precisely such a sense of fixity that expressionism's re-writing of the discursive world, its creation of images "under erasure", set out to undercut" (Murphy 261).
} 
sentido del espacio, de los símbolos — por enumerar algunas de las instancias más evidentes-, se asocia aquí al concepto de parodia expresionista y postmoderna, cuya "reescritura del mundo no solo pone de relieve la ficcionalidad inherente a todas las cosmogonías existentes, metalenguajes y grand récit, sino que también y quizás lo más importante, insiste al mismo tiempo en la provisionalidad de su propia verdad" (Murphy 263). Esto se demuestra en las duplicidades, mise-en-escéne o simulaciones que aparecen reiteradamente en la novela interrumpiendo el curso de la tensión lineal de las historias e introduciendo nuevos modos de percepción, entre ellos, el del cinismo cómico, el sarcasmo y la desublimación de situaciones de horror extremas por medio de la intertextualidad folletín-Abigail-Sembrando Flores como ejes narrativos predominantes.

$\mathrm{Al}$ igual que en la parodia expresionista y la literatura postmoderna, el narrador y la protagonista no imitan "a la naturaleza sino a otros textos" y lo hacen por la vía menos convencional y fidedigna, esto es, por vía del recuerdo (Stam 132). En este sentido, el relato, como apunta Robert Stam, "no es una ventana al mundo sino al palimpsesto, un evento intertextual, cuyas referencias a otros textos flotan entre líneas o permanecen en los márgenes" (132). Para Coll, el palimpsesto narrativo de Solo los elefantes... se utiliza para articular distintas "metanarraciones" (208). Ahora bien, el aspecto más significativo de esto, en relación con el estudio de los géneros literarios que trasuntan la obra, es que esta parodia o contrapunto desublimizante entre lo cursi, lo sentimental, el horror, el suspenso, lo "anti-cursi" y "lo sencillamente horroroso" se elabora sobre la base de la memoria, la cual, según Sembrando Flores tiene sus buenos "sobrevivientes mnemónicos", pero también sus "trampas" (Somers 168). Esta base memorística del texto 
se complica, desde luego, cuando se la asocia a la mandrágora, vinculada, entre otras cosas, con sus "antecedentes psicológicos”, es decir, su locura.

La memoria, concebida así, en términos "mandragóricos", (como misterio, locura, recuerdo, realidad, interior, sueño, homúnculos), instrumento o vehículo de la parodia, se transforma en un conocimiento transgresivo doble: primero, porque roza el misterio que está por debajo de anécdota y, segundo, por su poder de creación, que para la protagonista parece ser la mejor opción. ${ }^{159}$ En este sentido, de la combinación de la parodia y la memoria resulta una paradoja doble también: que ambas tienen un potencial “conservador y transformador" “mistificador” y crítico (Hutcheon 101). Y así, pues, la parodia unifica y reconcilia al tiempo que diferencia (102). Abigail leía los folletines por mor y evasión literal de la realidad cuando sus hijos yacían abandonados por su propio capricho, mientras que Sembrando también yace enferma como ella y lee los folletines como ella, pero no sólo por distracción, sino por necesidad de terror y por una conciencia de lo horrendo que podríamos calificar de ética. ${ }^{160}$ Así al menos parece cuando Sembrando Flores observa, como parte de un sentido de responsabilidad, prestar especial atención a la pesadilla:

Hay gente que despierta y pretende quitarse hasta el último resto del naufragio en el terror traspasando su angustia a los que escuchan. Y luego vienen los analistas y dicen cosas sacadas del mismo molde: el déjà vu de los retornos ancestrales y las visiones proféticas, los crímenes y los descubrimientos de los sonámbulos, la patética memoria intrauterina. Pero

\footnotetext{
159 "Sólo parecía quedar como posibilidad menos compleja intentar el juego al revés con las agujas del reloj, o invertir la clepsidra, o recurrir a las agendas viejas en busca de nombres olvidados. O decidir que si bien se camina sobre la a alfombra, también la alfombra puede caminar con nosotros, pero hacia atrás del tiempo, donde reaparecen las mejores piezas históricas" (199).

160 “Sembrando Flores se vio a sí misma (...) esperando la cuota del terror como si éste fuera también algo necesario para seguir existiendo, un factor de equilibrio dentro de la complicada red de tensiones y distensiones del alma humana" (Somers 217).
} 
nada de eso es suficiente, faltará siempre lo tremebundo de sentir el desprendimiento de la especie, repetirse la raíz que quizá se fuera en un principio, comer la tierra, oler la tierra, pudrir la tierra y no poder abandonarla si la planta se ha secado por arriba. Y entonces, al abrir los limitados ojos, el pobre y precario sapiens verá venírsele su orgullo al suelo, y aquel cavernario de carne cruda y lucha a muerte con los monstruos conformará un delicado ejemplar de evolución. Esto es de mucho antes, donde sólo la pesadilla puede llegar. (...) únicamente ella es la gran dueña de los significados (...) la pesadilla (...) nos ha revolcado en lo que nadie ha entrevisto aún, tal vez para no morir de tristeza en el cepo colombiano que nos sujeta a las verdades esenciales. (115)

Esta nueva forma de trascendencia inscrita en el marco de la reescritura del mundo secular, donde los sueños constituyen una dimensión de lo irrepresentable, lo desconocido y lo innombrado en relación con lo abyecto, constituye un claro contradiscurso ante el ilusionismo y formas de representación de corte idealista, en que el arte se eleva al plano de la expectativa ideal. En cambio, la novela plantea una necesaria memoria primordial del mundo, anterior a toda forma de "civilización" como fuente de "verdades esenciales". Esto puede verse como una de las muestras más evidentes del expresionismo gótico postmoderno en Solo los elefantes..., en que se deshace de la convención y de los discursos dominantes por la vía de lo oscuro, lo oculto y el mal que habita en la naturaleza humana.

Desde el punto de vista de la estructura de la historia, en que se entretejen tantas realidades simultáneas, distantes en tiempo, en estilo, siempre por medio de una memoria selectiva donde lo pesadillezco del terror primordial y del actual (reflejos de una apocalipsis igual en distintas eras de la historia) prevalece, bien puede remitir a la memoria, en su exceso, como otra forma de locura. El exceso de recuerdos, que es "locura de la memoria (...) [cuando] es interna, [como] un deseo, una reminiscencia", conforma así otra de las inversiones de sentido del texto, cuando la locura se presenta 
como una vía legítima de estar y de ser en el mundo (Felman 80). Así lo señala Sembrando al referirse a todos los que habitan esa isla de los "raros" que como ella, son quienes en realidad piensan "con coherencia temática", y añade: "Lo de ustedes cambia, se dispersa, mientras la locura persiste en la solidez de sus engendros" (272). Ante esta suerte de defensa de la locura, Susana Zanetti hace una observación significativa. En contraste con las narraciones realistas, donde el discurso se tiende a trazar líneas de pensamiento que se adhieren a imaginarios delimitados por culturas afirmativas, la ficción en la novela, "no rechaza ni los milagros ni a Satanás (...). No investiga, descifra, confiada en los sueños y en la coherencia de la locura" (53).

La acotación resulta de sumo interés en el ámbito de la ontología y de la metafísica que propone la novela, pues se advierte de nuevo lo que hemos llamado en otra oportunidad la perspectiva inclusiva de la narrativa de Somers, la cual radica tanto en el plano de la organización del relato como en el modo de percibir el mundo. Este método no debe confundirse con una simple acumulación de hechos, como advierte Zanetti, pues en esa "locura" del sueño de la imaginación sobreexcitada, propia del la situación de soledad y de terror sublime que vive la protagonista, existe una estrategia cuya clave está precisamente en la deconstrucción continua de historias y de discursos de toda índole (ideogramas, fotografías, grabados, fórmulas) y en todas las formas (rezos, exclamaciones melodramáticas, cartas, monólogos, diálogos, divagaciones, lecturas en voz alta, calladamente, escritos con y sin estilo, cursilería, comicidad, superstición, historias grotescas, tristes, desesperadas, fantásticas, etc.) y en algo más: en saber “atar los cabos". ${ }^{161}$ La parodia funciona aquí de manera análoga a la memoria, en cuanto a que

161 "Y entretanto el novelista ha llamado a todo esto que va del relato del Libro Sexto del Primer Tomo, 
tiene el efecto de borrar, como indica Niebylski "toda línea divisoria entre la historia (documental) y la ficción, (...) la historia archivada y la memoria individual o colectiva", cuando la perspectiva que sirve de orientación para reordenar los sucesos de la vida de la protagonista no está en un orden "externo", sino en unos folletines góticos melodramáticos que nadie lee (Patologías postmodernas 261). “Atar los cabos” sería el método más efectivo para conservar la memoria de aquel "amasijo recurrente de la vida" (Somers 247). ${ }^{162}$

En este orden de ideas, el exceso de inestabilidad de la representación por medio de la autorreflexividad narrativa, de autoconciencia de saberse su propia "Providencia", puede decirse, junto con Pérez de Medina, que esta profusión indecible de historias, símbolos y significados llevada al extremo en Solo los elefantes... se caracteriza por su "positividad", no solo por su inteligencia de saber extraer y combinar "lo prestigioso con lo desprestigiado, el folletín y Leopardi”, sino porque mueve a “pensar y a leer en exceso", por la fascinación del "exceso de sentido" y de terror podríamos añadir (31). El sentido último ofrece tantas alternativas como lecturas posibles. Sin embargo, ateniéndonos al testimonio en el que podemos optar en creer, si aquellos cuadernos eran la historia tanto de quienes se sentaban en el banquillo como del "frasco terrorífico" del que pendía su vida, y si en los cuadernos fue donde finalmente encontró, como lo

\footnotetext{
"Cabos Sueltos", justamente en la primera mitad de la página 531 donde termina el capítulo. . Y durante la inundación Marianna estaba sola en aquella colina con las flores bordadas y la redundancia de su hija llamada Fiorella (...). Y la Divina Comedia en italiano ilustrada por Doré yacía enflaquecida como un cadáver dentro de la hermosa mortaja de sus cubiertas, porque siempre la mortaja será eso. Un lindo disfraz para la inexistencia. (...) Y todo tan lejos de eso que acaba de caerme al pie de la cama, su comprimido, doctor Lilium, y al mismo tiempo tan cerca" (Somers 128).

162 “[E]ra necesario retomar los cabos sueltos antes de la posible entrega de la memoria junto con lo que irían a leer en sus vísceras (...) el día del descuartizamiento" -la delicada operación del Quilotórax- (225).
} 
confiesa, la mandrágora, entonces podemos decir que asistimos, como afirma Blixen, a la verdadera "escenificación de la novela interior de la protagonista" (206). Y con esto parece que la novela es entonces una muerte, que al atar los cabos sueltos transforma así "la vida en destino, el recuerdo en un acto útil, y la duración en un tiempo dirigido y significativo" (Barthes, El grado cero 45). Una muerte dudosa, por supuesto, si como los folletines estos escritos tienen también "algo como el pelo de los muertos: inertes en cuanto a cosas, pero existentes si se piensa que crecen" (Somers 17).

El carácter abrumador de la inestabilidad de representación de Solo los elefantes... puede considerarse como la manifestación expresionista de vanguardia más contundente de Somers. Simultáneamente, lo extraño, lo sublime, lo alucinante próximo al misticismo y el carácter abismal de la novela, demuestran una indagación exhaustiva en el género gótico postmoderno. La nostalgia y la parodia del gótico tradicional y su concomitante autoconciencia narrativa al borde del delirio revelan, asimismo, un profundo conocimiento del género gótico y sus vínculos con el gótico postmoderno. Rasgos como la duplicidad y la confusa densidad de marcos narrativos, que ahondan en el caos y en el misterio, sugieren que la condición humana pertenece a un mundo bizarro y extraño, donde el terror se presenta como la única forma de acercarse a lo real. La muerte simbólica como vida y su envés, aunado a la poética inclusiva que disuelve toda oposición binaria (sueño/realidad, mal/bien, nada/todo, locura/lucidez) ponen de relieve la inefabilidad de todo discurso en tanto contenido nebuloso, infinitamente interpretable. Todo lo cual conduce a pensar que esta obra ofrece una ruta potencial a una experiencia arcana relativa a lo irrepresentable, y por lo que puede considerarse parte del desarrollo evolutivo del expresionismo gótico postmoderno. 


\section{Conclusiones}

El análisis de las cinco novelas de Armonía Somers ha puesto de relieve la vigencia de los principios de la estética expresionista de vanguardia y del gótico postmoderno principalmente en el tipo de experiencia que los relatos articulan, lo que en el marco del expresionismo de vanguardia corresponde al ámbito de lo "inefable" y en el género gótico postmoderno a lo "irrepresentable". A diferencia de los géneros literarios dominantes en el contexto literario socio-histórico de la década del cincuenta, época en que aparece la primera novela de Somers, y en que la representación de la realidad se ajusta a los convencionalismos estéticos del realismo, la realidad que se plantea en la narrativa de Somers es de naturaleza interior, donde la anécdota y los sucesos de la historia están subordinados a los procesos psíquicos de los personajes. Esta subjetividad puesta en escena se manifiesta por medio de una marcada incertidumbre y sensación de la "nada", que en el gótico se asimila con el "terror sublime": estado de suspensión o de desorientación acompañado de una fuerte sensación de vacío, pérdida del sentido y de la fe. El terror sublime anticipa lo que en el lenguaje gótico se conoce como "muerte simbólica" o experiencia de la muerte en vida característica de la postmodernidad.

Tanto en el expresionismo de vanguardia como en el gótico postmoderno la experiencia de muerte simbólica se traduce en el plano de la representación por medio de la atmósfera propia del sueño o del trance hipnótico, con lo que ambas formas estéticas conectan con una psicología profunda e inconsciente amén de expresar una experiencia profundamente personal.

En la narrativa de Somers lo irrepresentable gótico postmoderno o inexpresable del expresionismo de vanguardia, conceptos que remiten a una misma experiencia en este 
marco de estudio, se articula por medio de la práctica deconstructiva de los modos de representación convencionales de corte realista. Así, el sentido de unidad típico de la modernidad, donde el relato sigue una línea argumental lógica sin lagunas que completar por parte del lector y cuyas partes coinciden con el todo en términos de una organización armónica, se rechazan aquí en favor de experiencias caracterizadas por una creciente alienación y sentimiento de otredad. Hay quienes han interpretado esta alienación de forma sociológica, como en el caso de La mujer desnuda (1950), novela en que los críticos han visto una crítica social más pronunciada (Rodríguez-Villamil 147, Blixen 198). Pero el aspecto enajenante de la sociedad y de las convenciones de todo orden no aparece solo en esta primera novela, en que la protagonista es de hecho víctima de un pueblo bárbaro enfurecido. También está presente la alienación societaria en De miedo en miedo. Los manuscritos del río (1965), donde el personaje se ve asediado por las convenciones de una sociedad machista, y en Un retrato para Dickens (1969), donde la negligencia del orfanato queda expuesta en la historia de una huérfana que escasamente sobrevive para contarla. En Viaje al corazón del día. Elegía por un amor secreto (1986) se narran los horrores de la guerra y ambas figuras protagónicas dan cuenta de los prejuicios y las idiosincrasias castrantes de finales del siglo XIX. Coll indica, asimismo, que en Solo los elefantes encuentran mandrágora (1986) "La complicada estructura narrativa tiene como fin presentar el momento histórico clave de forjarse el Estadonación burgués en Uruguay, las altas expectativas y su consecuente fracaso" (208).

Sin embargo, la alienación real de los personajes de Somers no se limita a una enajenación de los otros, lo que obedecería a una estética estrictamente realista, sino que se extiende a una enajenación abisal de sí mismos, de allí la postmodernidad de los 
relatos, y de allí, también, el cinismo y la oscuridad que trasuntan. El aspecto "social" que estas narraciones contemplan tiene que ver, más bien, con una preocupación ética que Somers desarrolla en toda su novelística y que descansa en su concepción de la subjetividad y sus procesos, entre ellos cómo se forma en ella la responsabilidad hacia los otros, lo extra-ordinario, lo propiamente sagrado en el mundo de Somers: las relaciones humanas.

Concretamente, la otredad de los personajes se revela por medio de ecos, voces, en algunos casos imágenes y símbolos que, a manera de dobles, completan el carácter de su persona. Esto se aviene a la concepción inorgánica del personaje expresionista de vanguardia, que a ratos puede parecer una abstracción, otras una persona de carne y hueso, apuntando siempre a una naturaleza misteriosa y en último término, se revela indescifrable. Asimismo, la pluralidad de voces o tipos que se asocian con un mismo personaje apuntan al carácter espectral, incierto e indefinido que caracteriza al ser gótico postmoderno.

La estructura La mujer desnuda se ajusta al Bildungsroman o novela de formación, si se atiende a la evolución de los sucesos y a la transformación paulatina que sufre el personaje, cuya metamorfosis alcanza el clímax en la decapitación y continua desarrollándose hasta el final, donde se produce la hierogamia amorosa y muerte de los amantes. Hasta aquí la novela posee una línea argumental progresiva y algunos rasgos descriptivos remiten a una estética modernista. Sin embargo, la ambigüedad del significado último de la novela es ineludible cuando la parquedad de la sintaxis, las elipsis de contenido y la plurivalencia de símbolos incorporan cada vez más sentidos en el relato y complica su compresión. El final abierto culmina por entroncar la obra con el 
texto expresionista de vanguardia cuando se distancia de las estrategias convencionales que emplea la narrativa realista para dar un cuadro único y completo de la obra, y cuando subvierte el propio concepto de realidad al reproducir una experiencia fundamentalmente caótica (Murphy 15).

Es evidente que el tipo de vivencia que el relato intenta transmitir es, antes que anecdótico, de naturaleza psíquica, razón por la que el modo expresionista de vanguardia se enlaza aquí con el gótico postmoderno, cuando ambos se concentran en articular el mundo interior del personaje. Asimismo, ciertos rasgos del gótico femenino son fáciles de distinguir en Rebeca Linke, quien como las protagonistas de éste género sufre un encarcelamiento (mental) y traspasa con mucho los límites de lo socialmente aceptable. Rebeca va en pos del descubrimiento de sí o del misterio de su existencia, lo que otros han llamado la búsqueda de su autenticidad o de su libertad. Esta conquista que, recordemos, se opera por medio de la decapitación del personaje y la reincorporación de la cabeza, imagen sin precedentes en la historia de la literatura, sienta desde entonces las bases de una perspectiva inclusiva dominante en toda la novelística de Somers, en que la muerte forma parte natural del vivir, y los deseos ocultos y necesidades veladas son acaso tanto o más importantes que las de la razón. ${ }^{163}$

La continua inversión de expectativas, la orientación ontológica de la búsqueda del personaje, así como la riqueza simbólica, inaprensible en su totalidad por parte del lector confirman la postmodernidad de La mujer desnuda. Particularmente el estrecho margen que se traza entre ficción y realidad marca la orientación autorreflexiva que

\footnotetext{
${ }^{163}$ Lo que Somers propone a partir de aquí es una perspectiva en que los pares opuestos (vida y muerte, real e imaginario, comunicable e incomunicable, mal y bien, dolor y alegría), dejan de ser contradictorios, algo que Bataille asocia significativamente con la "violencia de la experiencia mística", experiencia que según él alcanza "el más profundo sentido" (32).
} 
caracterizará toda la novelística de Somers. Ana María Rodríguez Villamil la identifica aquí como una doble realidad, un continuo "vaivén o (...) deslizamiento de un plano real a otro fantástico" donde resulta casi imposible distinguir el contenido meramente simbólico del real (147-9). La plasmación de los hechos desde el punto de vista del sueño o trance hipnótico conecta la obra con la estética expresionista de vanguardia, en que "el autor trata de imitar la (...) aparente lógica del sueño", y donde "todo puede ocurrir; todo es posible y probable. El tiempo y el espacio no existen", con el fin de expresar una "situación invisible" (Sokel 38).

Evelyn Picón Garfield tiene una posición significativa al respecto. Ella plantea que este tratamiento "onírico" es la forma que Somers escoge para expresar la presencia de la muerte en sus distintas manifestaciones, algo se ha dicho también de Strindberg, ${ }^{164}$ y que enlaza nuevamente la idea de lo inefable del expresionismo con la experiencia de muerte simbólica o de lo irrepresentable del gótico postmoderno en la temprana narrativa de Somers (Blixen 201).

La muerte es también uno de los tópicos centrales de De miedo en miedo. Los manuscritos del río (1965), su segunda novela. A pocas páginas el personaje principal apunta concretamente a la materia que ocupa al relato: el tormento interior y los miedos que lo asedian, clave que aparece señalada ya en el título y que constituye una de las preocupaciones fundamentales del expresionismo de vanguardia y del góticopostmoderno. ${ }^{165} \mathrm{Si}$ en La mujer desnuda se privilegia el presente, a partir de esta novela la búsqueda del personaje se enfila hacia una comprensión de sí desde el pasado,

\footnotetext{
${ }^{164}$ Ver en "The Representation of Death in Strindberg's chamber Plays”, de Freddy Rockem, p. 122.

165 “[E]mpecé a revivir una agonía en varios tiempos que la memoria me tenía guardada sin rendirme cuentas (...) que yo tuviera siempre un miedo loco de morir" (Somers 16).
} 
entroncando el tópico de la nostalgia típico del modo gótico. La memoria como forma de auto-indagación será de hecho uno de los pilares estructurales de su última y más complicada obra, Solo los elefantes encuentran mandrágora (1986). Como en esta última novela, el vacío y el automatismo del día a día conducen al recuerdo y la nostalgia, lo que Fred Botting vincula con el despertar de la "ansiedad narrativa" o necesidad urgente de articular el estado de incertidumbre en que se encuentra el personaje.

Desde el punto de vista del desarrollo del expresionismo de vanguardia y del gótico postmoderno en las novelas de Somers, De miedo en miedo (1965) introduce la metaficción como vehículo epistemológico de auto-examinación del personaje, radicalizando la búsqueda modernista del conocimiento del sí mismo y reorientando, consecuentemente, la aproximación del lector hacia cuestiones ontológicas (Beville, Gothic-postmodernism 46). Basándose en memorias pasadas, el protagonista se propone escribir sus memorias incluyendo en ellas toda suerte de detalles, sucesos, pedazos de vida ignorados, como "dibujos mal hechos, cajones llenos de esas cosas que significaron alguna vez y luego se hicieron basura. Trapo quemado de vida que se gastó diciendo buenos días a todo el mundo, (...) Y muchos materiales más... Quién sabe si con largos períodos en blanco", con el fin de ir "mucho más lejos" que los relatos convencionales (Somers 66, 59). Esta actitud cínica del narrador reevalúa no solo el concepto de realidad, sino también la manera de ficcionalizar esa realidad sin excluir lo comúnmente marginal, leitmotiv de peso en la literatura postmoderna (Beville, Gothic-postmodernism 46).

La multiplicidad de las distintas voces de su conciencia desplegadas en el relato forman parte de este intento por incluir lo liminal, ya que estas voces que él mismo trata de ignorar son síntoma de una heterogeneidad que él en el fondo añora y necesita para 
mantenerse vivo. Esta experiencia se aviene con la del terror sublime del gótico postmoderno, en que la destrucción del todo y reinstauración de la "heterogeneidad pura" se obtiene por medio de la vivencia de lo irrepresentable: el parto de su terror, o lo que él llama “desborde final de desesperación” (102).

En la ficción de Somers no es raro que las figuras masculinas experimenten sensaciones o experiencias físicas comúnmente reservadas a las mujeres. Ya en el cuento El despojo un hombre era penetrado por los fluidos de una mujer, mientras que aquí el hombre describe literalmente su propio parto. Esta "permeabilidad" entre los géneros (hombre-mujer), como concede Alexandra Fitts en la narrativa de Somers, se ve con mayor claridad cuando el protagonista de De miedo en miedo... asume características propias de la heroína gótica (109). Aquí el varón en lugar de ser el típico transgresor es prisionero y víctima de su esposa, una "mujer desconocida" que era en realidad su "celador" y la cual, junto con su hijo, formaba una especie de monstruo bicéfalo o "figura de dos cabezas con el mismo pelo, el mismo espejo de alma" (Somers 62).

La inversión de roles del género gótico femenino, el énfasis en la alteridad del personaje, su sentimiento de otredad y alienación de los otros y de sí mismo, la experiencia del terror sublime y abolición de la idea de totalidad por medio de la trama fragmentada y el carácter inorgánico del personaje, son todos aspectos expresionistas góticos postmodernos.

Al igual que en La mujer desnuda (1950), De miedo en miedo... (1965) culmina con la imagen del río, símbolo plurivalente en la narrativa de Somers y que concentra la metáfora de la literatura como historia secreta, oscura y cambiante. La inserción de los versos de César Vallejo al final de la novela repite el intertexto que ya aparecía en la 
primera novela al final, e incrementa la mezcla de géneros discursivos (diálogos, monólogos, cartas, fragmentos de diálogos, poemas) que posteriormente Somers explorará con vehemencia. En este relato la combinación de géneros discursivos ahonda en la idea del sinsentido como parte del tránsito y en la condición humana como una narrativa laberíntica en sí misma, carente de significado unívoco.

La subjetividad expresionista gótico postmoderna, que por medio de la experiencia de angustia y terror se muestra como "un proceso en continuo desarrollo, fundamentalmente incompresible", se extiende y complica en la tercera novela de Somers, Un retrato para Dickens (1969) (Murphy 17). El conglomerado intertextual del relato, que combina el texto bíblico de la historia de Tobías, la confesión de una huérfana en la actualidad, las cartas y recetas de un panadero y, por último, la versión de todas estas historias registradas por un loro, encarnación del demonio judío Asmodeo, sitúa de entrada la novela en la escritura postmoderna. La distorsión de la perspectiva tradicional por vía de la parodia y el énfasis en la ficcionalidad de todo texto, reflejada en los subtítulos, que califica de "documentos" tanto al grand récit bíblico como al Manual del Confitero, concuerda con la llamada "desublimación" de todo discurso que pretende ser absoluto, propia de expresionismo de vanguardia y de la postmodernidad.

Simultáneamente, el exceso referencial a que conduce el cruce de una historia tan remota como la del Antiguo Testamento, la confesión de una huérfana al borde de la muerte y el inusitado testimonio de un loro-demonio, produce, asimismo, un efecto "totalizador" o acaparador de sentido de la obra de cara al lector, para quien el relato resulta una experiencia apabullante. 
La metaficción del relato prueba ser doblemente gótica, no solo porque las historias que la conforman son todas góticas (todos son personajes presos, perseguidos, seres espectrales), sino por el impacto "diabólico" que causan en el lector, para quien la pluralidad de sentido desborda la capacidad interpretativa en una cadena de cuestionamientos sin fin. ${ }^{166}$ Igualmente, la inversión grotesca de expectativas que se da al acercar a la niña (la inocencia) más a la naturaleza de Asmodeo (lo diabólico) que a lo arquetípicamente divino (Tobías) ocurre una transgresión de lo sublime propia del gótico postmoderno, que privilegia una visión heterogénea del sujeto: la experiencia simultánea de terror, miedo y sensación de estar suspendido (Beville, Gothic-postmodernism 25). El ambiguo vínculo que mantienen la huérfana y el demonio Asmodeo por medio del trance hipnótico que ambos comparten, repite la experiencia del terror que se viene operando en las novelas anteriores, ya que tanto en La mujer desnuda (1950) como en De miedo en miedo... (1965), el terror sublime se asocia con la vivencia del absurdo marcada por el estado de trance hipnótico, en este caso concentrado en la imagen de una niña símbolo de inocencia y de destrucción.

El eje temático de los símbolos de la religión católica se retoma y añade una variación a la imagen de Cristo: si antes Rebeca (protagonista de La mujer desnuda) podía verse como una versión del Cristo crucificado, aquí la "sacrificada" es la huérfana, según sucesivas menciones del relato, y en el cual se señala su experiencia como "algo peor que la caída", aludiendo claramente a Jesús. La deconstrucción de los arquetipos

\footnotetext{
${ }^{166}$ Particularmente confuso resultan las analogías dispares entre figuras, como la niña y el loro-demonio, el loro y la mujer del Asilo, el loro como metáfora de cáncer no obstante ser compasivo con el viejo enfermo, la madre dura como una piedra -la única sin dobles en el relato- pero que al final se le asocia también con el loro. En fin, el surgimiento de dobles incongruentes crea espejismos desorientadores. El lector nunca tiene la seguridad de conocer a ningún personaje en rigor.
} 
cristianos así como de la concepción de Dios se repite, pues, en Un retrato..., donde Dios es simplemente un "Ojo" impasible que todo lo ve, pero que nada hace, reiterando la indiferencia que aparecía ya en la esculturilla de la Virgen María o "mujercita" que Rebeca Linke contemplara camino al pueblo. En uno y otro caso las novelas insisten en que la fuente del mal no está en un ente superior, ya sea Dios o el mismo demonio (como Asmodeo), sino en los seres humanos (los pobladores en La mujer desnuda y los seres extraños que habitan en el inquilinato de Un retrato...).

Asimismo, el "fenómeno" que el protagonista de De miedo en miedo... experimentara ${ }^{167}$ reaparece en Un retrato..., si bien aquí la subjetividad "interrumpida" alcanza un grado de estupefacción mayor. La idea de la atemporalidad o de un tiempo "sin relojes" apunta nuevamente el estado de terror sublime que en uno y otro personaje se conecta con la incertidumbre de lo que ellos mismos pueden saber o imaginar de sí mismos, leitmotiv del gótico postmoderno (Beville, Gothic-postmodernism 25). De ahí que la imaginería de la muerte en Somers asome una salida momentáneamente consoladora, si se piensa en que al fin los personajes conciben su estado concretamente, que es el de saberse "muertos".

La tranquilidad consciente que le sucede a Rebeca tras la decapitación y restitución de la cabeza, lo mismo que al protagonista de De miedo en miedo... luego de imaginar su entierro, no es distinta a la de la niña cuando se ve como "un alma errante": hay un alivio en el terror sublime de la muerte simbólica, en que la razón cognitiva y la

\footnotetext{
167 “Era un fenómeno extraño y primerizo, algo de lo que jamás hubiera podido responder anteriormente. Frené para esperar que dieran paso al camión, y el pensamiento que traía colocado sobre mi cabeza se quedó quieto" (Somers 27).
} 
objetividad se desechan a favor de la imaginación y el deseo. ${ }^{168} \mathrm{Si}$ bien desde un punto de vista gótico postmoderno estas características reflejan una existencia irreal e indefinible, este sentirse seres anónimos es lo que, no obstante, promueve la búsqueda de autodeterminación.

La fotografía que aparece en la portada de la novela en Un retrato... es objeto de transformación imaginaria para la huérfana, quien al compararse con Oliver Twist comienza a reconocerse en ese "otro", significativamente ficcional. La inserción de la fotografía, un intertexto nuevo en la sucesión de novelas, añade, en rigor, nuevas formas de terror, si se toma en cuenta que la huérfana es ya existencialmente una figura liminal y que, al equipararse con un personaje de ficción, resulta doblemente espectral: un personaje de ficción reflejo de otro personaje de ficción.

Más aún, la narrativa de Somers cristaliza aquí lo que se viene perfilando en las novelas anteriores en la deconstrucción de los estándares individuales, morales y culturales, pertinente a una postura vanguardista: que la realidad de "ser" solo puede experimentarse por medio de la recreación ficcional y simbólica del terror, que somos seres en búsqueda de esa ficcionalidad, que es búsqueda del sí mismo. Esta es la experiencia que la narrativa de Somers extiende al lector, la cual se corresponde, paradójicamente, con la misma premisa postmoderna de no tener otro conocimiento que el de la incertidumbre.

El tema del bien y el mal en Un retrato..., aunque opera de manera confusa y desestabilizadora en su estructura discontinua, plantea por medio de la representación del

\footnotetext{
168 “[E]1 fenómeno: sentir que ya no estaba en el suelo, sino que iba planeando a corta distancia de la tierra (...). Lo practiqué con los ojos cerrados, luego haciendo intervenir las cosas. Era simplemente cuestión de intentar un pequeño esfuerzo y desprenderse. Al fin se manejará quién sabe qué dispositivo interno de dirección, y ya no más problemas con el cruce de calles, con subir aceras y umbrales" (Un retrato... 18).
} 
exceso el punto de partida para una comprensión de estos conceptos en Somers, y que tienen que ver con lo que podemos llamar una "percepción integradora" que desdibuja los contornos entre contrarios, presente ya en La mujer desnuda y en De miedo en miedo. La historia de Tobías, paradigma católico de probidad, y el registro del milenario diablo Asmodeo dan cuenta del exceso por vía del contraste: exceso de fe en Tobías, hasta la ceguera; exceso de incredulidad en Asmodeo, hasta la renuncia a la vida. En ambos el mal se manifiesta a través del vicio, ya sea por la extrema virtud o total ausencia de ella. En la huérfana este exceso se previene por medio de dos fuentes: el reconocimiento de la belleza y la memoria como herramienta de aviso, ambos recursos del místico y del santo (Castelli 86). En la novela todos los personajes están expuestos al laberinto: el inquilinato es un lugar de alienación y de ruptura social, un espacio disfuncional donde la conexión del individuo con la familia se pierde en la arbitrariedad y la confusión (Botting, Power in the Darkness 261). Pero solo la niña logra sobrevivir a este asalto infernal por medio del recuerdo de lo bello en medio de lo horrendo. ${ }^{169}$

Esta visión no es distinta a la que se presenta en La mujer desnuda. Rebeca significativamente recordó que "dentro de su libro de cabecera había una pequeña daga que era una obra de arte, tanto como para decapitar a una mujer prisionera" (Somers 18). El arma del crimen como arte coloca la decapitación como un acto, asimismo, bello, con lo que el mal aquí se torna vehículo del "bien”, entendiendo por verdadero crimen el ajuste mecánico a las convenciones (Dios, la familia, las relaciones tipificadas, caducas

\footnotetext{
${ }^{169}$ La huérfana "había aprendido a guardar todo en buen orden en la memoria, por si un día era preciso echar mano a algo y encontrarlo", memoria que le permite recordar la belleza de la mujer del Cuñado en el momento crítico de la visita de la directora del Asilo a punto de llevársela, y que le hace acordarse de su madre cuando yace en la cárcel sola, dándole fuerzas para contar su historia (Somers 47, 76-7, 16).
} 
entre los hombres) de las que el personaje se deslinda violentamente para sobrevivir. El recuerdo de la belleza es crucial. Por el recuerdo, la anamnesis, "el hombre que se excede puede volverse atrás; el vicio puede ser combatido" (Castelli 86). En Somers el mal aparece entonces como necesario, como fundamento también del ser, pues aún cuando lo horrendo haya prevalecido y se haya impuesto sin dejar ver los límites, la seducción de lo bello sirve de vía para retornar a lo bello, y el engaño y lo horrendo sirven entonces de aviso, de recuerdo pero como instrumento de lucha para oponerse (87). Por eso la niña en el calabozo, tras la horrible violación y su "caída" al mar logra narrar su historia: por el recuerdo de la madre, "único ser real" que había conocido.

Viaje al corazón del día. Elegía por un amor secreto (1986) constituye en gran medida el "vuelco" de la escritura de Somers cuando esta visión del exceso como vía de expiación, que se viene desarrollando a lo largo de sus tres primeras novelas, del mal como "atracción hacia la muerte", se trasciende por vía del recuerdo de lo bello como amor, siendo este siempre de naturaleza espectral y caracterizado por el amante ausente. Que el "otro" amado sea el punto de encuentro entre la mayor plenitud que se pueda experimentar y el terror sublime aparece ya en la hierogamia de los amantes en La mujer desnuda (1950), momento clímax que precede la muerte literal de Rebeca Linke (Somers 117-9). La naturaleza espectral del amado se concentra asimismo en la figura de la desconocida en De miedo en miedo. Los manuscritos del río (1965), en quien el protagonista encuentra a su alma gemela aun cuando esta solo existe en su imaginación.

En Viaje... la inexistencia del ser amado queda declarada desde el principio de la historia, pero ya no es un acicate de muerte literal, porque también allí la muerte deja de ser un hecho fatídico, y en cambio es fuente de memoria, "donde lo muerto continúa 
estando vivo" (Castle 132). La memoria de lo bello y el amor prueban ser más fuertes que la muerte, una idea que se retoma y se profundiza en la crítica de la postmodernidad, y que el personaje de Laurent manifiesta cuando antes de morir le propone a Laura la eterna reunión en una proyección futura del pasado: "vuelvo hacia atrás de nuestras vidas y te veo siempre, esa será la fórmula (...) la invertirás y me tendrás” (Levinas 126; Somers 102).

La fórmula de trascender a la muerte por medio del recuerdo señala asimismo el carácter ambiguo de los escritos, ya que siendo Laura narradora y ella misma Laurent (el difunto amante), la narración se postula como la voz de la muerte articulada o de lo que "ya no (...) se es", como agrega Hildegard (Somers 115). ${ }^{170}$ Desde el punto de vista de la estructura, el doble relato autobiográfico en que una historia funciona como eco y o continuación de la otra, siendo ambos discursos individuales, remite a otro aspecto del gótico postmoderno y del expresionismo de vanguardia que Somers ya había asomado en Un retrato...: la idea de que "todo [texto] es un intertexto", ya sea por medio de la parodia de los textos o, como en este caso, de la exageración melodramática (Mendoza Fillola 57). Si antes esto se traducía en la combinación de hipotextos e hipertextos, como los fragmentos extraídos casi literalmente del Antiguo Testamento y la narración figurada del demonio Asmodeo, en Viaje..., la inserción de cartas enteras, incluso en otros idiomas, de fragmentos de diálogos, citas, frases extraídas del Corán, todo esto en el marco de las dos narraciones autobiográficas, señala el carácter metanarrativo y autorreflexivo de la historia, más aún cuando al final descubrimos que en su conjunto las

\footnotetext{
170 "Laurent era yo y yo Laurent", "Laurent era mi identidad, pues al no cambiar él yo permanecía en mí que era él mismo. Íbamos en una carrera desigual en el tiempo, pero nadie nos quitaría lo inmutable, el estar uno dentro del otro aunque simulando dualidad", "una Laura-Laurent siempre ausente de la discreción elemental" (21, 45-6).
} 
historias han sido editadas por seres "extraños por nacimiento" que "saben ordenar datos, llenar las lagunas a fuerza de imaginación, mantener a la gente en vilo con posibles finales" (Somers 86-7).

La analogía entre la ficción y la vida, que ya se planteara en Un retrato para Dickens (1969) se retoma en Viaje... por medio de la paridad que se establece de continuo entre la ficción y los documentos notariados, las novelas por entrega y los nombres propios, las cartas personales y las descripciones interminables de novelones, dicho esto por los propios personajes. ${ }^{171}$ Además, la necesidad de la protagonista de esclarecer su origen por vía de la escritura y recopilación de datos retoma, igualmente, la metaficción que planteara el personaje de De miedo en miedo..., y hace énfasis de nuevo en una narrativa de la psique o "coloquio" interior, propio de la novela gótica y del expresionismo de vanguardia (Somers 81; Punter 14).

La deconstrucción de los modos narrativos canónicos, en este caso, el melodrama, cuyo estilo parodia la novela, se da cuando este mismo sirve para insistir en el mito del romance y en las limitaciones del lenguaje, recalcando su aspecto sagrado o el sentido "otro" de una experiencia signada por la pérdida y el vacío. Viaje... se vale de la escritura melodramática como modo de abstracción para revelar que el mundo de "afuera" o de los hechos es un mundo de apariencias. La "tan mentada historia" oficial en que la novela registra, se reemplaza por la visión "conceptual” y reconstructora del artista, que Laura describe como una comunidad de "locos en apariencia a quienes les da por escribir

\footnotetext{
171 "Yo había leído el nombre en una novela por entregas", escribe Encarnación a Refugio, a propósito del nombre que puso a su hija Eulalia. También Laura se refiere a "la novela de Las Nubes"; y en carta a Refugio, le informa que desenredó "las novelescas y abultadas carpetas del notario respecto a Las Nubes". Más adelante le avisa que las cartas están debajo de los "novelones encuadernados en fino cuero de Rusia con títulos dorados a la hoja", y le pide no sacarlas de ahí, pues "en realidad en ese sitio todo deberá ser lo mismo, novela, porque tales cosas nadie las inventa, se van tejiendo solas" (Somers 31,28, 85).
} 
poesías, novelas, o inventar paraísos sociales que nunca van a llegar a verse", "orates" que "rumian fantasías" $(83,86)$.

La necesidad de Laura y de Hildegard del artificio "novelesco" para articular lo irrepresentable, coincide con la preocupación del melodrama expresionista por la desaparición de los valores sagrados que, por lo mismo, se han tornado inexpresables y han quedado como un lado marginal de la experiencia (tal el amor y el duelo amoroso). Esta experiencia está asociada en la novela con un estado de "suspensión" en que el sujeto es presa de un "terror irracional" ante el amor, verdadera experiencia abisal aquí, donde el "otro" se presenta como lo abominable y lo desconocido de sí, al tiempo de ser fuente eterna de vida, fenómeno fundamental de que trata el gótico postmoderno como una experiencia de terror sublime (Somers 68, 74, 24; Beville, Gothic-postmodernism $15)$.

De igual forma, la preferencia de Somers por una ubicación temporal de un período de entre guerras para su novela, en una época que puede considerarse asimismo "intermedia" como el fin del siglo XX, adquiere sentido en el marco de la estética gótica postmoderna y del expresionismo de vanguardia, ya que ambos modos abordan la ambigüedad ontológica inherente a los tiempos de cambio, tal como la que precedió a la inauguración del modernismo (Beville, Gothic-postmodernism 99).

Como en las dos novelas anteriores, el tiempo y el espacio en Viaje... son plurales, pasado, presente y futuro interactúan en dimensiones paralelas en el marco de la experiencia subjetiva, un tropo fundamental de la trama inorgánica del expresionismo y de la discontinuidad de los esquemas narrativos gótico-postmodernos. El epílogo de la novela reitera, asimismo, la naturaleza "inconclusa" a que remiten los personajes, y 
apuesta por un relato "abierto" ("no, el ciclo no se había cerrado aún”), determinado por una doble otredad: la nueva Laura, ahora musulmana, y el mensaje de Hildegard, escrito en griego. La extrañeza de este nuevo "marco" de la novela ofrece una mirada que se acerca a lo fantástico y a lo grotesco, más cuando Laura incluso legitima la "locura" como algo "necesario a fin de que el mundo no desaparezca en la uniforme mediocridad" (Somers 145). Es evidente que una lectura exclusivamente realista del texto resulta inviable, ya que la premisa bajo la cual se rige Viaje... es la indeterminación, que niega la base de esa percepción realista de identidades unívocas.

Solo los elefantes encuentran mandrágora (1986) constituye en este sentido la suma de todas las premisas desestabilizadoras de la realidad en términos expresionistas gótico postmodernos observadas a los largo de las novelas anteriores. En esta como en ninguna de sus otras obras Somers despliega una poética del exceso, tanto del sentido de la historia que allí se narra como de los ámbitos de estudio del texto literario diseminados en ella, desde el punto de vista de su creación y de su percepción. Novela autorreflexiva, su postmodernidad es de un marcado carácter gótico y expresionista de vanguardia, cuando las líneas intertextuales recurrentes giran en torno a la parodia del folletín, a la novela gótica del siglo XIX, al relato autobiográfico o "autoficción”, todas enmarcadas en tópicos de "sexo, violencia, enfermedad y muerte" (Pérez de Medina 35).

La muerte es un tropo que explora Solo los elefantes... en profundidad. La novela gótica del siglo XIX escrita por Pérez Escrich, folletines que le leía su madre a Doña Abigail, constituye el primer intertexto de la obra y uno de los ejes fundamentales en torno a la búsqueda de la identidad de la protagonista. Nuevamente, el hilo que une a estas historias es el género gótico, la parodia y el expresionismo de vanguardia, si bien en 
esta oportunidad las relaciones entre el gótico tradicional y el gótico posmoderno se indagan con más fuerza.

La historia del cráneo de Margarita, acompañada de un grabado en que la calavera domina la escena en la sala del Conde, sirve de símbolo y reflejo del frasco terrorífico que pende lleno de linfa en el cuarto de la enferma. Estas repeticiones de escenas, situaciones, personajes y motivos echan las bases de una deconstrucción sucesiva de identidades que problematizan la estructura narrativa y los modos de percepción, ampliando cada vez más el marco referencial y simbólico de la obra en su conjunto.

La desublimación y el anti-ilusionismo se dan aquí por medio de las interrupciones de las tramas, que suspenden la tensión de la línea narrativa y relativizan las asociaciones entre lo serio y lo cómico, lo banal y lo profundo. Esta misma volubilidad del relato es la fuente de ambigüedad y cumple la función propia del melodrama expresionista de dirigir la atención del lector hacia lo aparentemente insulso en aras de que él mismo construya el significado del texto.

El tópico del sueño, la alucinación, el trance hipnótico y los poderes sobrenaturales de la mente y del cuerpo aparecen aquí estrechamente vinculados con la experiencia de la enfermedad, la cual a ratos representa la muerte de la protagonista en su aspecto negativo, y otras oportunidades refleja su identidad monstruosa, pero como elemento de comicidad y parte natural del sí misma.

La muerte adquiere en esta novela una naturaleza casi obsesiva paranoide y reiteradamente aparece como la única instancia del entramado simbólico que no acepta mofas ni historias, como el tema anti-deconstruible por antonomasia. Ante esto, el personaje opta por la memoria, teñida de visiones, sosteniendo diálogos con fantasmas, 
seres espectrales también, que como ella habitan en la "isla de los raros" (Somers 118).

Estos personajes pasan por dobles, otras como aspectos o partes de la misma protagonista, una configuración inorgánica de la figura típica del expresionismo de vanguardia. Las visitas y el carácter fabuloso que adquieren los monólogos y diálogos simulados por la enferma, así como las alusiones continuas a su estado "histérico", su delirio y defensa declarada de la locura, colocan el discurso en la frontera de lo creíble y lo fantástico. Sin embargo, las divagaciones mentales de la protagonista y el cruce de intertextos, personajes, escritores, teorías, por mencionar solo algunas de las intromisiones, no restan coherencia a la obra, sino que amplían su marco de referencia, aludiendo a la cualidad inefable de la experiencia.

El carácter autorreflexivo de la novela en torno a sus símbolos, como la mandrágora, la nada, Dios, Dante y el infierno, Quilotórax (la enfermedad), por mencionar algunos, elabora una especie de ars memoria somersiana en que las imágenes van adquiriendo cada vez más capas de significado, no sólo por medio de las historias que allí aparecen, sino también porque en muchas oportunidades resuenan como ecos de las novelas anteriores, que ubicados en un contexto nuevo, resultan excesivos.

Esta autoconciencia del texto consigo mismo también reflexiona sobre la importancia de la pesadilla y el terror como vehículos catárticos y seña de advertencia, con lo que por distintas vías metaficcionales, el texto nos confronta con una experiencia de corte místico violenta, en términos de desarrollar el hábito de "la conciencia como tarea" y "sin que exista un fin y un saber absoluto" (Eco, Semiótica 261). El tópico de la mística como experiencia de lo irrepresentable y transgresión de los grand récit, es aquí una de las líneas expresionista gótico postmoderna más pronunciada de la obra y sella el 
marco metafísico-ontológico que trasuntan todas sus novelas, una suerte de "vía negativa" por la que apuesta, que resulta, no obstante y paradójicamente la más positiva, porque admite una percepción incluyente, que no desecha nada (Pérez de Medina 32).

En este recodo parece revelador que Sembrando Flores remita a una idea de George Bataille, cuando dice "El medio no interesa, sino los individuos", haciendo énfasis en la capacidad imaginativa y la emoción como medio eficaz o lugar a partir del cual puede captarse mejor lo real (Somers 34). ${ }^{172}$

Solo los elefantes encuentra mandrágora es quizás la obra más compleja de la autora por su extensión y la enorme cantidad de temas y exceso de sentidos en que indaga en profundidad. Su conocimiento del gótico tradicional y del gótico postmoderno se evidencia en el uso audaz de la parodia y en la inteligencia para articular una subjetividad arrasada por una experiencia irrepresentable. Las distintas intertextualidades que emplea, el delicado y difícil tejido de las tramas y subtramas que emergen como un denso rizoma apuntan a una narrativa postmoderna que se adelanta a su época no solo en el plano formal sino en el de las ideas. Por eso es legítimo pensar que la novela contribuye a la evolución del género expresionista gótico postmoderno como uno de sus ejemplares más peculiares.

Finalmente, todas las novelas de Somers pueden ser interpretadas como obras expresionistas gótico postmodernas por las siguientes razones: primero, porque sirven de manifestaciones artísticas y exploraciones de la experiencia subjetiva del terror. Segundo, porque la narrativa trabaja en función de desestabilizar los discursos dominantes de poder y las oposiciones aceptadas mal/bien, ser/otro, ficción/realidad, salud/enfermedad, por

\footnotetext{
${ }^{172}$ Bataille apunta, a propósito de "la literatura violenta como la violencia de la experiencia mística", que "El camino importa poco: solo el lugar, el punto, importa" (32).
} 
medio de la imaginería gótica, la "visión" expresionista y la aproximación postmoderna a la realidad como infinita e inabarcable, con lo cual expone toda una gama de prejuicios de género, sexuales, raciales, etc. que consume la sociedad postmoderna. Y, cuarto, porque para develar esta condición interior del individuo se vale de elementos metaficcionales tales como la intertextualidad, lo sobrenatural, el misterio, lo grotesco y el suspenso. Para resumir, las obras expresionistas gótico postmodernas analizadas en este trabajo despliegan una fascinación por lo "negativo", lo "irracional", lo "inmoral" y lo "fantástico" (Botting 2003). Toda la realidad en las novelas está teñida de incertidumbre, oscuridad, transgresión y seres espectrales. En contraste con los acercamientos teóricos previos sobre la prosa de la autora en cuestión, este estudio ofrece una aproximación contemporánea a la novelística de Somers de cara a la literatura postmoderna. 


\section{Referencias}

Aguirre, Manuel. "Narrative Structure, Liminality, Self-Similarity: the Case of Gothic Fiction." A Place that is not a Place. Ed. Isabel Soto. Madrid: Gateaway Press, 2000. 133-147. Print.

Araujo, Helena. "El tema de la violación en Armonía Somers y Griselda Gambaro." Plural 15.179 (1986): 21-23. Print.

Bachelard, Gaston. Lautréamont. Dallas: Pegasus Foundation, 1986. Print.

Bataille, George. La literatura y el mal. Madrid: Taurus, 1981. Print.

Barthes, Roland. El grado cero de la escritura. México: Siglo Veintiuno Editores, 1987. Print.

Beville, Maria. Gothic-postmodernism. Voicing the Terrors of Posmodernity.

Amsterdam: Rodopi, 2009. Print.

—. Otherness. A Multilateral Perspective. Frankfurt am Main: Peter Lang, 2011.

Beauvoir, Simone. The Second Sex. New York: Vintage, 1974. Print.

Biron, R.E. “Armonía Somers 'El despojo': Masculine Subjectivity and Fantasies of

Domination.” Latin American Literary Review 21. 42 (1993): 7-20. Print.

Botting, Fred. Gothic. New York: Routledge, 2010. Print.

—. "Power in the Darkness. Heterotopias, literature and Gothic laberynths." Genre 26 (1993): 253-282. Print.

Brooks, Peter. The Melodramatic Imagination. Balzac, Henry James, Melodrama and the Mode of Excess. New Haven: Yale UP, 1976.

Bürger, Peter. Theory of the Avant-Garde. Mineapolis: Minnesota UP, 1984. Print.

Burke, Edmund. A Philosophical Inquiry into the Sublime and The Beautiful. London: Penguin, 1998. Print.

Calafell Sala, Núria. Armonía Somers. Por una ética de lo excéntrico. Vigo: Editorial Academia del Hispanismo, 2010. Print.

Campodónico, Miguel Ángel. “Diálogo.” Armonía Somers, papeles críticos. Cuarenta años de literatura. Ed. Rómulo Cosse. Montevideo: Librería Linardi y Risso, 1990. 22545. Print. 
Castle, Terry. "The Spectralization of the Other in The Misteries of Udolpho." The Female Thermometer $18^{\text {th }}$ Century Culture and Invention of the Uncanny. New York: Oxford UP, 1995. 120-139. Print.

Castelli, Enrico. Lo demoníaco en el arte: su significado filosófico. Madrid: Siruela, 2007. Print.

Clark, Maria B. "Desirous Fiction or 'El hombre del túnel' by Armonía Somers." Romance Language Annual 4 (1992): 404-10. Print.

Coll, Doreley Carolina. "La pulsación del discurso femenino en la modernidad después del 'Pos': Solo los elefantes encuentran mandrágora de Armonía Somers." Revista de Crítica Literaria Latinoamericana 56 (2002): 205-218. Print.

Cosse, Rómulo, ed. Armonía Somers. Papeles Críticos. Montevideo: Librería Linardi y Risso, 1999. Print.

Dalmagro, María Cristina. "The Reversal of Innocence: Sommers, Dickens, and a 'Shared Oliver'." Dickens Studies Annual: Essays on Victorian Fiction 36 (2005): 319-30. Print.

Dámaso Martínez, Carlos. “Armonía Somers. 'Quien escribe no es quien existe'.” El arte de la conversación: Diálogo con escritores latinoamericanos. Argentina: Alción Ed., 2007. 75-78. Print.

Dapaz Strout, Lilia. "La rebelión de la flor: la metamorfosis de un ícono en El derrumbamiento.”Armonía Somers, papeles críticos. Cuarenta años de literatura. Ed. Rómulo Cosse. Montevideo: Librería Linardi y Risso, 1990. 53-86. Print.

Dupree, Robert S. Lautréamont. Dallas: Pegasus Foundation, 1986. 103-123. Print

Eco, Umberto. Obra abierta. Barcelona: Planeta-Agostini, 1985. Print.

—.Semiótica y filosofía del lenguaje. Barcelona: Lumen, 1990. Print.

Eliot, Thomas. "Introduction to Nightwood." Nightwood. London: Faber, 1974. Print.

Felman, Shoshana. Writing and Madness (Literature/Philosophy/Psychoanalysis). California: Standford UP, 2003. Print.

Fleenor, Juliann E. Introduction. The Female Gothic. Ed. Juliann E. Fleenor. MontrealLondon: Eden P., 1983. 3-30. Print.

Fishburn, Evelyn. "Aproximaciones a un cuento de Armonía Somers: 'La inmigrante'." Fragmentos 6. 1 (1996): 109- 120. Print. 
Fitts, Alexandra. “Armonía Somers's Permeable boundaries”. Hispanófila 137 (2003): 101-114. Print.

Foster, David W. Unamuno and The Novel as Expressionistic Conceit. Puerto Rico: Inter American UP, 1973. Print.

Frank, Marcie. "At the Intersections of Mode, Genre, and Media: A Dossier of Essays on Melodrama". Criticism (2013): 540-2. Print.

Freud, Sigmund. "De guerra y muerte. Temas de actualidad.” Trans. José L. Etcheverry. Obras completas XIV (1914 - 1916). Ed. James Strachey. Buenos Aires: Amorrortu editores, 1992. 273-301. Print.

Frye, Northrop. Anatomía de la crítica. Caracas: Monte Ávila Editores, 2001. Print.

García Rey, José Manuel. "Armonía Somers: Sondeo intuitivo y visceral del mundo." Cuadernos Hispanoamericanos 415 (1985): 101-4. Print

Geoffrey Kantaris, Elia. The subversive psyche: contemporary women's narrative from Argentina and Uruguay. Oxford: Oxford UP, 1995. Print.

Girona, Núria. "Indecibles e imposibles de la escritura: Armonía Somers y Clarice Lispector." Lectora 13 (2007): 101-114. Print.

Gomes, Miguel. "Para una teoría del ciclo de cuentos hispanoamericanos". Revista de Filología Hispánica 16. 3 (2000): 557-583. Print.

Green, Roland. The Princeton Encyclopedia of Poetry and Poetics. $4_{\text {th }}$ ed. New Jersey: Princeton UP, 2012. Print.

Hagenbüchle, Roland. "The Concept of Ambiguity in Linguistics and Literary Criticism." Modes of Interpretation; essays presented to Ernst Leisi on the occasion of his $65^{\text {th }}$ birthday 1 (1984): 213-221. Print.

Harkness, James. Introduction. This is not a Pipe. By Foulcault. Ed. and trans. James Harkness. Berkeley: California UP, 2008. Print.

Hutcheon, Linda. A Theory of Parody. The Teachings of Twentieth-Century Art Forms. Urbana and Chicago: Illinois UP, 2000. Print.

Jung, Carl Gustav. Simbología del espíritu. México: FCE, 1998. Print.

Kantaris, Elia Geoffrey. The Subversive Psyche. Contemporary Women's Narrative from Argentina and Uruguay. New York: Oxford UP, 1995. Print. 
Kayser, Wolfgang. Lo grotesco. Su realización en literatura y pintura. Madrid: Visor, 2010. Print.

Kearny, Richard. Strangers, Gods and Monsters. Londond: Routledge, 2003. Print.

Kristeva, Julia. Sol negro. Depresión y melancolía. Caracas: Monte Ávila, 1992. Print.

-. Powers of Horror. New York: Columbia UP, 1982. Print.

Lautréamont. Los Cantos de Maldoror. Ed. and trans. Manuel Serrat Crespo. Madrid: Cátedra, 2008. Print.

Levinas, Ennmanuel. Dios, la muerte y el tiempo. Madrid: Cátedra, 2012. Print.

Leeuwen, Frederike van. "Female Gothic: The Discourse of the Other." Revista canaria de estudios ingleses 4 (1982): 33-44. Print.

Lindstrom, Naomi. Literary Expressionism in Argentina. Tempe: Center for Latin American Studies, Arizona State University, 1977. Print.

Lutz, Deborah. "The Haunted Space of the Mind: The Revival of the Gothic Romance in the Twenty-First Century." Empowerment versus Oppression; Twenty-First Century Views of Popular Romance Novels. Ed. Sally Goade. Newcastle upon Tyne: Cambridge Scholars Publishing, 2007. 81-92. Print.

Lyotard, Jean Francois. The Lyotard Reader. Oxford: Blackwell, 1991. Print.

McMillen, Syndy C.. "The Reconstruction of the Gothic Feminine Ideal in Emily Brontë's Wuthering Heights." The Female Gothic. Ed. Juliann E. Fleenor. MontrealLondon: Eden P., 1983. 91-106. Print

Martínez, Elena. "La ambigüedad y el papel del lector en El desvío." Armonía Somers, papeles críticos. Cuarenta años de literatura. Ed. Rómulo Cosse. Montevideo: Librería Linardi y Risso, 1990. 105-18. Print.

McHale, Brian. Postmodern Fiction. New York: Methuen, 1987. Print.

Mendoza-Fillola, Antonio. «Los intertextos: del discurso a la ficción.” Intertextos: aspectos sobre la recepción del discurso artístico. Eds. Antonio Mendoza Fillola y Pedro C. Cerrillo. Cuenca: Universidad de Castilla La Mancha, 2003. 17-60. Print.

Moers, Ellen. Literary Women. New York: Doubleday and Company, Inc., 1976. Print.

Moore, Charles B. "El papel del lector activo en 'La inmigrante' de Armonía Somers." Chasqui 26.1 (1997): 45-55. Print. 
Moraña, Mabel. Memorias de la generación fantasma. Montevideo: Monte Sexto, 1988. Print.

Morris, David. “Gothic Sublimity.” New Literary History. 16.2 (1985): 299. Print.

Murphy, Richard. Theorizing the Avant-Garde. Modernism, Expressionism, and the Problem of Postmodernity. United Kingdom: Cambridge UP, 1999. Print.

Niebylski, Diana C. "Sick Bodies, Corrosive Humor: Armonía Somers.” Humoring Resistance. Laughter and the Excessive body in Latin-American Women's Fiction. New York: SUNY P, 2004. 95-123. Print.

—. "Patología postmodernas: reflexiones sobre los poderes de la abyección en Solo los elefantes encuentran mandrágora." El salto de Minerva. Intelectuales, género y Estado en América Latina. Ed. Mabel Moraña y María Rosa Olivera-Williams. Madrid: Iberoamericana/Vervuert, 2006. 254-268. Print.

Parkinson Zamora, Lois. Narrar el apocalipsis. México: FCE, 1994.

Penco, Wilfredo. "El amor en el centro del mundo (Viaje al corazón del día)". Armonía Somers, Papeles críticos. Cuarenta años de literatura. Ed. Rómulo Cosse. Montevideo: Arca, 1990. 173-7. Print.

Perera San Martin, Nicasio. “Armonía Somers: una trayectoria ejemplar.”Armonía Somers, papeles críticos. Cuarenta años de literatura. Ed. Rómulo Cosse. Montevideo: Librería Linardi y Risso, 1990. 17-37. Print.

Pérez de Medina, Elena. "Sobre Armonía Somers". Atípicos en la literatura latinoamericana. Ed. Noé Jitric. Buenos Aires> Universidad de Buenos Aires, 1997. 2735. Print.

Picón Garfield, Evelyn. "La metaforización de la soledad en los cuentos de Armonía Somers." Armonía Somers, papeles críticos. Cuarenta años de literatura. Ed. Rómulo Cosse. Montevideo: Librería Linardi y Risso, 1990. 41-52. Print.

Pinthus, Kurt. "Versucht eines zukunftiges Dramas." Schaubühne 10.14 (1914): 391-394.

Punter, David and Glennis Byron. The Gothic. Malden: Blackwell, 2004. Print.

Rama, Ángel. “La fascinación del horror.” Marcha 1188 (1963): 30. Print.

—. Prólogo. Aquí, cien años de raros. Montevideo: Arca, 1966. Print.

—. "Raros y malditos en la literatura uruguaya." Marcha 1319 (1966): 30-31. Print. 
—. "Mujeres, dijo el penado alto." Marcha 1290 (1966): 50. Print.

Robert, Marthe. Lo viejo y lo nuevo. Caracas: Monte Ávila, 1993. Print.

Rodríguez Villamil, María. "Aspectos fantásticos en 'La mujer desnuda' de Armonía Somers." Cultura 1 (1985): 147-163. Print.

Rougemont, Denis de. Love in the Western World. New Jersey: Princeton UP, 1983.Print.

Ruffinelli, Jorge. "Armonía Somers: paraíso infernal, celeste infierno.” Crítica en marcha. Ensayos sobre literatura latinoamericana. México: Premia Editora, 1967. 270276. Print.

Sencindiver, Susan Yi, Maria Beville, and Marie Lauritzen. Otherness. Frankfurt am Main: Peter Lang, 2011. 45-60. Print.

Shelly, Mary. Frankenstein o el modern Prometeo. Madrid: Alianza, 1998. Print.

Snook, Margaret L. "Who's Pulling the St(r)ing? Gender and Class in Armonía Somer's 'Muerte por alacrán'." Ciberletras 13 (2005): 1-7. Web.

Sokel, Walter H. Expressionism in Twentieth-Century German Literature. The Writer in Extremis. California: Standford UP, 1959. Print.

Somers, Armonía. La mujer desnuda. Buenos Aires: El Cuenco de la Plata, 2009. Print.

-. Augusta: Clima, 1951. Print.

—. De miedo en miedo. (Los manuscritos del río). Montevideo: Arca, 1965. Print.

—. Un retrato para Dickens. Montevideo: Arca, 1969. Print.

—. Viaje al corazón del día. Montevideo: Arca, 1986. Print.

—. Solo los elefantes encuentran mandrágora. Buenos Aires: Legasa, 1986. Print.

—. "Carta abierta desde Somersville." Revista Iberoamericana 58160.161 (1992): 11551165. Print.

- " "Anthos y Legein. (donde la autora nos muestra la otra cara de las historias)." La rebelión de la flor. Antología personal. Montevideo: Linardi y Risso, 1994. 9-11. Print.

-. Prólogo. La otra mitad del amor contada por siete hombres. By Arregui et al. Montevideo: Arca, 1968. 7-9. Print. 
Stam, Robert. Reflexivity in Film and Literature. New York: Columbia UP, 1992. Print.

Sucre, Guillermo. La máscara, la transparencia. Ensayos sobre poesía hispanoamericana. México: FCE, 2001. Print.

Sullivan, Mary-Lee. "The Imagery Real in Three Short Stories by Armonía Somers." Cincinnati Romance Review 23 (2004): 165-182. Print.

Todorov, Tzvetan. Introducción a la literatura fantástica. México: Premia, 1981. Print.

Torres, Alicia. "Dicken's Oliver and Somer's Orphan: a Traffic in Identities." Dickens Studies Annual: Essays on Victorian Fiction 36 (2005): 331-40. Print.

Vardieri, Alejandro. "Armonía Somers: de la mujer y del amor, lo grotesco". Monographic Review 7 (1991): 227-35. Print.

Verdugo, Iber. "Concepción de totalidad y estructura narrativa (Viaje al corazón del día)". Armonía Somers, Papeles críticos. Cuarenta años de literatura. Ed. Rómulo Cosse. Montevideo: Arca, 1990. 179-196. Print.

Visca, Arturo Sergio. "Un mundo narrativo fantasmagórico y real." Armonía Somers, papeles críticos. Cuarenta años de literatura. Ed. Rómulo Cosse. Montevideo: Librería Linardi y Risso, 1990. 11-15. Print.

William Foster, David. Unamuno and the Novel as Expressionistic Conceit. Puerto Rico: Inter American UP, 1973. Print.

Williams, Anne. “The Male as 'Other'.” Art of Darkness, a Poetic of Gothic. Chicago: Chicago UP, 1954. 141-148. Print.

Williams, Raymond. Marxism and Literature. Oxford: Oxford UP, 1950. Print.

Zanetti, Susana. "Literatura y enfermedad en 'Solo los elefantes encuentran mandrágora' de Armonía Somers." Atípicos en la literatura latinoamericana. Ed. Noé Jitrik. Buenos Aires: Universidad de Buenos Aires, 1997. 47-56. Print.

Żižek, Slavoj. "Solo un Dios sufriente puede salvarnos." El dolor de Dios. Inversiones del apocalipsis. Ed. Slavoj Ẑiẑek y Boris Gunjević. Madrid: Akal, 2013. Print. 
Vita

\section{ANAMARÍA LÓPEZ-ABADÍA}

Born, Caracas, Venezuela

2001-2007

Licenciatura en Letras (B.A.)

Universidad Central de Venezuela

Caracas, Venezuela

2008-2014

Teaching Assistant

Modern Languages,

Florida International University

Miami, FL

$2010-2014$

Doctoral Candidate

Modern Languages,

Florida International University

Miami, FL

\section{PUBLICATIONS AND PRESENTATIONS}

"Vanguardia e innovación en La lluvia (1935) de Arturo Uslar Pietri"; Aguas del Pozo/Waters of the Well, $\mathrm{U}$ of North Carolina, Chapel Hill. Online Journal.

"Orientalismo: su síntesis y recreación en Tabú, film de Miguel Gomes". $5^{\text {th }}$ Conference on Orientalisms and the Asian and Arab Diasporas: Representaciones del/de lo oriental en las Américas y en la Península Ibérica - Paper presented at the Herzen State Pedagogical University of Russia, St. Petersburg; April 12, 2013. 